(Coordinadores)
José Manuel
Rosalía
maroto
López
Blanco
Fernández

Prólogo de Rosa M. Rodríguez Izquierdo

\title{
Migraciones y comunicación intercultural: una mirada interdisciplinar
}

Cuadernos Artesanos de Comunicación / 167

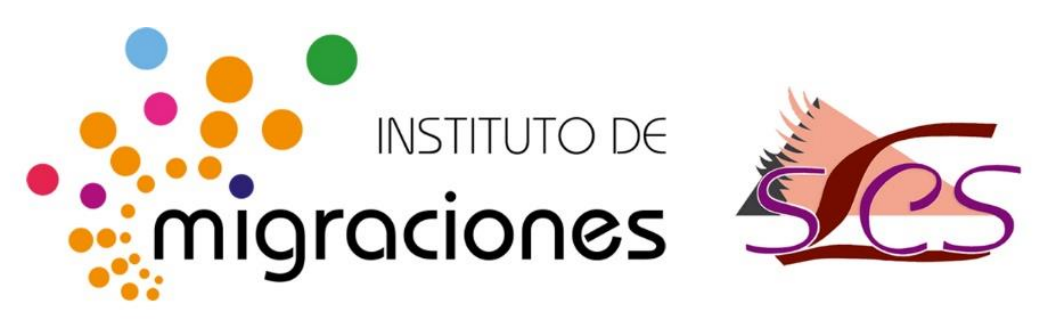




\title{
Cuadernos Artesanos de Comunicación \\ Coordinador editorial: José Manuel de Pablos - jpablos@ull.edu.es \\ Comité Científico \\ Presidencia: José Luis Piñuel Raigada (UCM) \\ Secretaría: Milena Trenta
}

- Victoria Tur (Universidad de Alicante, UA)

- Miguel Vicente (Universidad de Valladolid, UVA)

- Ramón Zallo (Universidad del País Vasco, UPV-EHU)

- Núria Almiron (Universidad Pompeu Fabra, UPF)

- Francisco Campos Freire (Universidad de Santiago de Compostela)

- José Cisneros (Benemérita Universidad Autónoma de Puebla, BUAP)

- Bernardo Díaz Nosty (Universidad de Málaga, UMA)

- Carlos Elías (Universidad Carlos III de Madrid, UC3M)

- Paulina B. Emanuelli (Universidad Nacional de Córdoba, UNC)

- José Luis González Esteban (Universitas Miguel Hernández de Elche, UMH)

- Marisa Humanes (Universidad Rey Juan Carlos, URJC)

- Juan José Igartua (Universidad de Salamanca, USAL)

- Xosé López (Universidad de Santiago de Compostela)

- Maricela López-Ornelas (Universidad Autónoma de Baja California, UABC)

- Octavio Islas (Universidad de los Hemisferios, Ecuador)

- Javier Marzal (Universidad Jaume I, UJI)

- José Antonio Meyer (Benemérita Universidad Autónoma de Puebla, BUAP)

- Ramón Reig (Universidad de Sevilla, US)

- Miquel Rodrigo Alsina (Universidad Pompeu Fabra, UPF)

- Xosé Soengas (Universidad de Santiago de Compostela)

- José Luis Terrón (Universidad Autónoma de Barcelona, UAB)

- José Miguel Túñez (Universidad de Santiago, USC)

\begin{abstract}
* Queda expresamente autorizada la reproducción total o parcial de los textos publicados en este libro, en cualquier formato o soporte imaginables, salvo por explícita voluntad en contra del autor o autora o en caso de ediciones con ánimo de lucro. Las publicaciones donde se incluyan textos de esta publicación serán ediciones no comerciales y han de estar igualmente acogidas a Creative Commons. Harán constar esta licencia y el carácter no venal de la publicación.
\end{abstract}

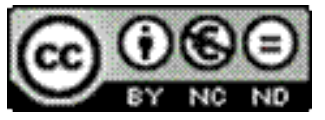

Este libro y cada uno de los capítulos que contiene (en su caso), así como las imágenes incluidas, si no se indica lo contrario, se encuentran bajo una Licencia Creative Commons Atribución-No Comercial-Sin Derivadas 3.0 Unported. Puede ver una copia de esta licencia en http://creativecommons.org/licenses/by-nc-nd/3.0/ Esto significa que Ud. es libre de reproducir y distribuir esta obra, siempre que cite la autoría, que no se use con fines comerciales o lucrativos y que no haga ninguna obra derivada. Si quiere hacer alguna de las cosas que aparecen como no permitidas, contacte con los coordinadores del libro o con el autor del capítulo correspondiente.

\footnotetext{
* La responsabilidad de cada texto es de su autor o autora.
} 
(Coordinadores)

José Manuel Maroto Blanco y Rosalía López Fernández

Prólogo de Rosa M. Rodríguez Izquierdo

\section{Migraciones y comunicación intercultural: una mirada interdisciplinar}

José Manuel Maroto Blanco, Rosalía López Fernández, Rosa M. RODRÍGUEZ IZQUIERDO, AlBERTO CAPOTE LAMA, MARTA ZORNOZA MADRID,

Xavier Brito Alvarado, Nelly Guamán Guadalima, GianluCa Gaias, Rosella Bianco, Mónica Ortiz Cobo, Alessandra Cama, Amaia GarcíaAZPuru, ARIET CASTILLO FERNÁNDEZ, RoCÍo GONZÁLEZ REY, VINCENZA INDELICATO, MARIA CAMA.

Cuadernos Artesanos de Comunicación / 167
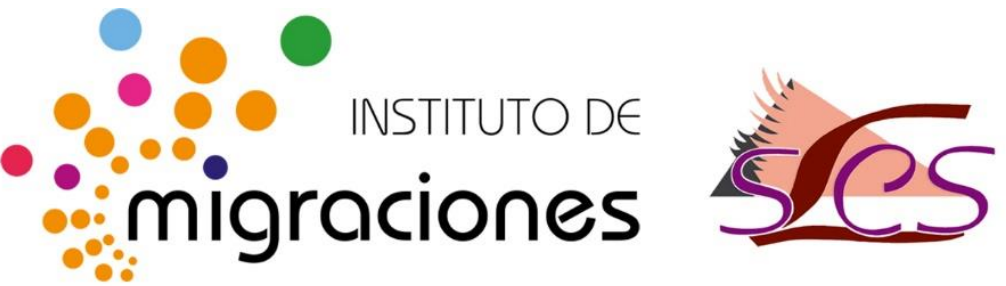
CAC $167^{\circ}$ - Migraciones y comunicación intercultural: una mirada interdisciplinar

José Manuel Maroto Blanco y Rosalía López Fernández (Coordinadores)

Precio social: 9,85€ | Precio en librería 12,80€ |

Editoras: Milena Trenta y Almudena Barrientos Báez

Diseño: F. Drago

Ilustración de portada: Fragmento del cuadro Mujer pensando de Vale (Bolonia)

Imprime y distribuye: F. Drago. Andocopias S. L.

c/ La Hornera, 41. La Laguna. Tenerife.

Teléfono: 922250554 | fotocopiasdrago@,telefonica.net

Edita: Sociedad Latina de Comunicación Social - edición no venal - La Laguna (Tenerife), 2019 - Creative Commons

http://www.revistalatinacs.org/14SLCS/portada2014.html

Descargar en pdf:

7http://www.cuadernosartesanos.org/\#cac167

Protocolo de envío de manuscritos con destino a CAC:

http://www.cuadernosartesanos.org/protocolo.html

ISBN-978-84-17314-28-6

DL: TF-1060-2019

DOI: $10.4185 / \operatorname{cac} 165$ 


\section{Migraciones y comunicación intercultural: una mirada interdisciplinar}

\section{Resumen}

En los últimos años las migraciones han comenzado a ocupar un espacio central en la agenda de instituciones internacionales, gobiernos y sociedad civil, despertando un interés paralelo en el ámbito académico que se ha visto reflejado en un aumento sin precedentes de la producción científica en esta temática. Así mismo, la presencia habitual de cuestiones relativas a las migraciones en los medios de comunicación de masas ha puesto de manifiesto la relevancia social, política, económica y cultural de estos fenómenos. Desde los medios de comunicación, así como desde las instituciones, la academia y la sociedad en general, se ha contribuido a crear modos y modelos de construcción e interpretación de la realidad migratoria, cuyas consecuencias precisan de un análisis en profundidad dado que muchas de estas elaboraciones suelen ser problemáticas al estar cargadas de prejuicios racistas, estereotipos xenófobos, sesgos y simplificaciones. A través de los capítulos de estas obras, se pretende poner en cuestión experiencias relacionadas con la comunicación, la educación y la interculturalidad o visibilizar espacios "otros" de creación de prácticas y discursos dominados por las propias poblaciones migrantes.

\section{Palabras clave}

racismo; prejuicios; medios de comunicación de masas; xenofobia.

Forma de citar este libro:

Maroto Blanco, J M.; López Fernández, R (Cords.) (2019). Migraciones

y comunicación intercultural: una mirada interdisciplinar. La Laguna, España:

Cuadernos Artesanos de Comunicación, cac 167. La Laguna

(Tenerife).

DOI: $10.4185 / \operatorname{cac} 167$ 


\section{Índice}

Prólogo: Migraciones y comunicación intercultural: una mirada interdisciplinar

Rosa M. Rodríguez Izquierdo.

1. Una perspectiva interdisciplinar en el estudio de los procesos migratorios: miradas complejas y voces diversas

José Manuel Maroto Blanco, Rosalía López Fernández.

2. El cine como herramienta para analizar los procesos de aculturación en distintos contextos europeos

Alberto Capote Lama, Marta Zornoza Madrid.

3. Entretenimiento y el espectáculo como discursos televisivos

Xavier Brito Alvarado, Nelly Guamán Guadalima

4. “Territorialización 2.0.": la red en los procesos migratorios y los social networks al servicio de las comunidades

Gianluca Gaias

5. Usos de las lenguas y preferencias lingüísticas entre inmigrantes y refugiados

Rosella Bianco, Mónica Ortiz Cobo.

6. Discurso del profesorado sobre alumnado extranjero y escolares con necesidades educativas especiales en la escuela italiana

Alessandra Cama

7. El condicionante de la terminología en el caso de las migraciones

Amaia García-Azpuru

8. ¿Cómo se cuentan las migraciones? Los "otros" desde "nosotros". Una aproximación inicial a qué es "noticia" en cuanto al fenómeno migratorio en términos de la representación mediática de la "población extranjera"

Ariet Castillo Fernández. 
9. Espacios de paz en las trayectorias migratorias de las personas de África subsaharianas que llegan a Melilla

Rocio González Rey

10. E1 "Italiano L2" en la escuela italiana: perspectivas de los profesionales de la escuela y del alumnado extranjero en las escuelas secundaria de segundo grado en Palermo

Vincenza Indelicato

11. Las lenguas de la comunicación de las trabajadoras domésticas filipinas de Mesina

Maria Cama

Los autores y las autoras.

El contenido de este libro ha sido sometido a un proceso de revisión de doble ciego por pares, semejante al sistema de revisión de un artículo científico para un journal. 



\section{(1) \\ Prólogo}

\section{Migraciones y comunicación intercultural: una mirada interdisciplinar}

A OBRA que aquí se presenta toma como foco los procesos
migratorios y busca comprenderlos desde una perspectiva compleja e interdisciplinar, respondiendo a algo que la sociedad actual demanda, ahora más que nunca, respuestas al desarrollo de las capacidades y requerimientos de una ciudadanía cuyos derechos son cercenados (Amartya Sen, 2011; Marta Nussbaum, 2015). Resulta sustancial establecer compromisos entre la investigación para lograr fines vinculados al bien común, a la calidad de vida, la igualdad de oportunidades, la equidad, la inclusión y la justicia social. La demanda de una dimensión social de la investigación, que contribuye así al desarrollo de sociedades sostenibles y al retorno del conocimiento a la sociedad resulta crucial, devolviendo con ello el sentido a una sociedad que aprende, se transforma profundamente y camina hacia su emancipación en un escenario postmoderno. Y, lo anterior, desde la legitimidad de comprometer a la investigación desde el reconocimiento de los saberes (de Sousa, 2017), la defensa de valores éticos, sociales y democráticos y de derechos humanos.

Como señalan en la introducción a este volumen José Manuel Maroto Blanco y Rosalía López Fernández, coordinadores y editores del libro, los que participan en sus análisis de la perspectiva de la complejidad aspiran a explicar aspectos identitarios de las personas migrantes desde una comprensión más radical que la que ofrecen los métodos analíticos de investigación convencionales. Y esto mismo es lo que se pretende con la publicación de esta obra: mostrar la fecundidad de los estudios 
migratorios desde un enfoque complejo para analizar y comprender procesos dialecticos, abiertos y mutables.

Sus editores se proponen una tarea ciertamente ambiciosa, introduciendo la cuestión de la complejidad y la interseccionalidad a la vez que intentan dar voz a las distintas voces en el campo de los estudios migratorios. Para ello, el libro se compone de una diversidad de investigadores e investigadoras de distintos contextos geográficos que intercalan reflexiones de diversas disciplinas en la que encontramos una reflexión desafiadora sobre la complejidad y la construcción de la diferencia. Sin embargo, este trabajo, se concibe como un excelente mirador que invita no solo a la reflexión sino también a la práctica investigadora comprometida como resultado de un diálogo personal e intelectual entre los y las investigadores y los y las personas investigadas.

Como señalan sus autores, el objetivo final que se marca esta publicación es doble: dar voz a los sujetos, a los protagonistas de las migraciones y desenmascarar la retórica que desde el poder quiere imponerse en torno a las personas migrantes. Por lo tanto, es un libro que suscitará mucho interés, tanto a los y las investigadores iniciados en el fenómeno, como a los que pretendan comprender el marco metodológico en el que se enmarca esta obra.

La publicación, desde el enfoque de la complejidad y la interseccionalidad, cuestiona el lenguaje que construye la diferencia desde la jerarquización y la identificación de las personas migrantes como sujetos etnificados. Los trabajos intentan huir de una visión simplificadora que desoye la complejidad de los procesos de exclusión e inclusión, y, en consecuencia, olvida el papel de lo "no dicho", es decir, de los "sistemas de razón" que, asignan significado a los individuos $y$, de ese modo, construyen diferencias.

En este sentido, cabe destacar el esfuerzo crítico que se realiza al intentar deslindar el empleo de una terminología que estructura las relaciones que configuran la identidad de un sistema desigual. Según Popkewitz (2006, 80), el problema reside en que "el sistema de argumentos" con el que se suele concebir y definir la diferencia "está formado y creado por normas y valores no dichos". Esta cuestión es, sin duda, crítica si se quieren comprender los fenómenos migratorios y 
las prácticas relativas a la diversidad y la inclusión/exclusión de las personas migrantes.

Muy esclarecedor resulta el intento de alejar el discurso del reduccionismo que acompaña a las personas migrantes que, con frecuencia, representan el temor de aquellos que son diferentes, de los que habitan los márgenes. Temor, de cuantos representan la negatividad, la fractura, en un mundo obsesionado por lo positivo, lo liso y lo igual (Han, 2015 y 2017). El trabajo apuesta por la tensión renovadora de la investigación cualitativa en aras de promover nuevas maneras de comprender la realidad de las personas migrantes, a menudo tergiversada, desde una epistemológica que trasciende Occidente y se abre al pensamiento del Sur (de Sousa Santos y Meneses, 2014).

El conjunto de trabajamos que se presentan en esta publicación asume como objeto fundamental de los estudios migratorios la comprensión del flujo ordinario de la vida humana. Apuesta por potenciar estratégicamente un posicionamiento que prima el estudio de las relaciones, así como de los procesos que subyacen a las mismas, en el marco de la dialógica y la agencialidad de las personas migrantes.

Cabe destacar que se trata de una obra que invita a reflexionar sobre las lógicas y los métodos de investigación necesarios para desarrollar una mirada compleja sobre los estudios migratorios que está prácticamente por hacer, al tiempo que denuncia silenciosamente la cortedad de miras de las visiones hegemónicas sobre "los otros". Al reflexionar sobre el significado de la identidad cultural en el discurso del nacionalismo, Bauman $(2017,70-71)$ hace un juicio similar: "E1 papel principal (y, con demasiada frecuencia, único) asignado al otro (o a los otros) sobre quien rociamos nuestras aspersiones es el de saciar nuestra propia sed de superioridad".

Los distintos capítulos que componen el libro justifican la necesidad de adoptar una mirada compleja para transformar sinérgicamente (investigadores/investigados) los fenómenos migratorios en la actualidad y reconstruir así el escenario social. Se trata, pues, de una visión que no se detiene en el problema de la diferencia en sí, sino que excava en su origen y significado. Y que plantea la construcción de sociedades que asuman la diferencia como constitutiva de la 
democracia, sociedades capaces de construir relaciones nuevas, verdaderamente igualitarias, entre los distintos grupos socioculturales, lo que implicaría empoderar a los que históricamente han sido menoscabados (Candau, 2013).

La obra abarca un arco interdisciplinar y contextual desde el que estaríamos en condiciones idóneas para comprehender mejor la realidad los fenómenos migratorios en la actualidad. Se apuesta en este libro por un nuevo paradigma de miradas y voces diversas en el que el conocimiento de los elementos estructurantes, institucionales y personales de las personas migrantes, de sus modos y criterios de interacción, dialogan de manera abierta. En la actualidad, los movimientos humanos se ajustan más a la idea de un continuo semántico en perpetua mutación y movimiento que, a un conjunto de agrupaciones estables de signos y significados, espacios y tiempos, separados entre sí o antinómicos (a semejanza de la dualidad exclusión/inclusión). Las representaciones de la otredad, y sus discursos asociados, son cada vez menos consonantes con los procesos culturales de la globalización. Se han vuelto pretéritos, y con ellos, todas esas lógicas analógicas en un mundo líquido y digital.

En definitiva, el esfuerzo coordinado por José Manuel Maroto Blanco y Rosalía López Fernández goza de un sólido rigor intelectual, constituyendo un hito indispensable dentro de la abundante producción científica existente en nuestro país en torno a los estudios migratorios. Sirve de pauta para quienes -desde cualquier ámbitoquieran penetrar en una retadora perspectiva de análisis complejo de estos fenómenos en devenir constante. Estamos ante un libro que sigue un invisible hilo conductor argumental: para comprehender los fenómenos migratorios hay que analizar paralelamente diversos contextos, y este no se entiende sin la ayuda de las distintas ciencias sociales y en diálogo honesto con las propias voces de las personas migrantes como agentes creadores de su realidad. Sin duda, una publicación que constituye una guía básica para todos aquellos que pretendan iniciarse en el estudio de las migraciones, así como una herramienta verdaderamente útil para los que aspiran a enfocar sus investigaciones sociales desde la perspectiva del análisis complejo.

Rosa María Rodríguez Izquierdo Universidad Pablo de Olavide (Sevilla) 


\section{Bibliografía}

Bauman, Z. (2017). Retrotopía. Barcelona: Paidós.

Candau, V. M. (2013). Educación intercultural crítica: Construyendo caminos. En C. Walsh, (Ed.), Pedagogías decoloniales: Prácticas insurgentes de resistir, (re)existir y (re)vivir (pp. 69-103). Quito: Ediciones Abya-Yala.

De Sousa Santos, B. y Meneses, M. P. (2014). Epistemologías del sur (Perspectivas). Madrid. Ediciones Akal.

De Sousa Santos, B. (eds) (2017). Justicia entre Saberes:

Epistemologías del Sur contra el epistemicidio. Madrid: Morata Han, B-Ch. (2015). La salvación de lo bello. Barcelona: Herder. Han, B-Ch. (2017). La expulsión de lo distinto. Barcelona: Herder.

Nussbaum, M. C. (2015). Philosophy and economics in the capabilities approach: An essential dialogue. Journal of Human Development and Capabilities, 16(1), 1-14.

Popkewitz, T. (2006). La expectativa acerca de la sociedad del futuro y el miedo a lo diferente. La escolaridad y la exclusión social. Anales de la Educación Común, 2(4), 78-94.

Sen, A. (2011). Desarrollo y crisis global. Madrid: Editorial Complutense S. A. 



\title{
Una perspectiva interdisciplinar en el estudio de los procesos migratorios: miradas complejas y voces diversas
}

\author{
José Manuel Maroto Blanco \\ Universidad de Granada, España \\ Rosalía López Fernández \\ Universidad de Granada, España
}

\section{Introducción}

UANDO se aborda el estudio de los procesos migratorios es $\checkmark$ frecuente que la relevancia de dichos fenómenos se plasme, principalmente, a través de cifras y otros datos cuantitativos. Sin embargo, los trabajos más recientes están poniendo de manifiesto que la investigación de los fenómenos migratorios requiere, además de datos demográficos o económicos, que se comprendan otra serie de procesos, hechos y dinámicas que son consecuencia intrínseca de la movilidad humana. Con esto nos referimos principalmente a toda una serie de fenómenos inherentes a cualquier actividad en la que existen interacciones entre distintos grupos de personas, como pudieran ser los procesos de inclusión-rechazo de los migrantes en las sociedades receptoras, las estrategias que estos ponen en marcha para hacer frente a barreras lingüísticas, económicas o administrativas, la reconfiguración de los mercados laborales en los países receptores o los procesos de intercambio cultural que se generan, entre otras diferentes cuestiones. $\mathrm{Y}$ es que no debemos olvidar que las migraciones son, en términos de 
Marcel Mauss (1971), un "hecho social total" en tanto que afectan a todos los grupos sociales y a todos sus integrantes, independientemente de su edad, sexo u ocupación y el momento histórico en el que se produzcan.

Debido a todas estas características, su estudio se debe complejizar, precisando que sea abordado mediante una mirada "densa". Desde los muy distintos ámbitos y contextos a los que se presta, ha de ser situada en los diferentes planos y dimensiones que abarcan desde lo personal hasta dimensiones estructurales. El estudio de las migraciones incluye, por tanto, cualquier espacio, actividad o interacción que afecta a todos los aspectos de la vida de las personas. A través de este capítulo, señalaremos tres dimensiones interconectadas que, pese a que las expondremos en epígrafes diferentes debido a fines puramente analíticos, no pueden entenderse de manera independiente unas de otras y presentan varias dificultades en su estudio.

\section{De lo personal a lo estructural}

En lo referente al plano individual y personal que recoge los aspectos identitarios de las personas migrantes, existe una tendencia a esencializar, fijar y materializar sus identidades de forma que puedan someterse a distintos procesos intelectivos. En este aspecto queremos llamar la atención sobre la necesidad de situar las narrativas, de no desvincular a las identidades de los sujetos y de los espacios que habitan y, en última instancia, de los lugares epistémicos que les son propios. El estudio de las identidades podría abordarse transformando las descripciones estáticas, reificadas, excluyentes, estereotípicas, simplificadas o sin contradicciones en descripciones que incluyan la multiplicidad, su carácter fluido, dinámico y contradictorio. Como señala Brubaker (2000), para superar todas estas complicaciones, se puede pasar de la identidad a la "identificación" como un proceso dialectico, abierto y mutable, conformado por distintas narrativas, relacional, y no meramente categorial.

Cuando describimos al "otro diferente" se establece un eje de normalidad que corresponde con la representación del "yo", del "nosotros" o de "lo propio" (Rodrigo Alsina y Gaya Morla, 2001). La estimación de los "otros", desde la medida de "normalidad" que representa lo conocido, no puede ser si no el exceso o el defecto que 
se observa en los demás, en aquellos que son construidos como diferentes y en último término como desiguales. La identificación de los mecanismos y procesos de diferenciación de la población de origen inmigrante es un aspecto esencial para llevar a cabo cualquier investigación en el ámbito de los estudios migratorios y a los que haremos referencia más adelante en este texto.

Desde el plano contextual, entendido como el entorno inmediato en el que se desarrolla la investigación sobre migraciones, son muchos los aspectos que entran en juego cuando se aborda el estudio de estos procesos. Por ser una dimensión que articula muchas facetas de la realidad migratoria, no debe pensarse como un espacio preexistente $o$ como un lugar físico en el que habitan determinados sujetos. Los contextos de los sujetos son "el lugar de las relaciones que los seres humanos mantienen con otros seres humanos y con los objetos de su mundo vital" (Díaz de Rada, 2010: 94) y estas relaciones no pueden ser separadas del dinamismo y de la multiplicidad de ámbitos que las caracterizan. La compresión exigua de los contextos en los que acontecen la realidad migratoria conlleva ciertas limitaciones pues se genera la fijación de los sujetos a los contextos, se producen sesgos en la compresión de los fenómenos y casi nunca se señalan como una construcción artificiosa de los investigadores. Un ejemplo que ilustra esto que estamos apuntando es la de los contextos escolares ya que en numerosos estudios se reducen los procesos educativos a lo que acontece únicamente o principalmente en la escuela. Es obvio que por razones metodológicas de carácter pragmático, los contextos deben ser precisados, pero no limitados.

Para abordar intelectualmente la investigación en migraciones hay que partir de una premisa básica y es que la "comprensión del mundo es mucho más amplia que la comprensión occidental del mundo" (Boaventura de Sousa, 2011: 16). Esta idea nos confronta con los constructos teóricos que tratan de explicar los movimientos migratorios reduciéndolos a su dimensión económica, sin poner el énfasis en el hecho de que "las migraciones son criaturas de las políticas" (Davis, 1988: 259). No se da cuenta, por tanto, de que el tipo de migraciones y el volumen de los flujos actuales perpetúan la dependencia y la desigualdad entre países. Una teorización epistemológicamente plural realizada desde una perspectiva 
interseccional (García Abad, 2003) sigue siendo necesaria para poder aprehender la realidad migratoria, especialmente la de los sujetos colonizados (Grosfoguel, 2012). Este punto de partida permite conectar la dimensión estructural de las migraciones con las realidades individuales, poniendo en valor una pluralidad de voces que de otra manera sería desestimada.

Una problemática común a estas dimensiones es confundir los objetos teóricos de estudio con los distintos grupos de personas migrantes, de forma que los sujetos se vuelven los objetos de la investigación. En esta misma línea vemos cómo en muchos trabajos se asume que los propios sujetos migrantes son incapaces de dar cuenta de las situaciones que viven negándoles la capacidad de definir la realidad en sus propios términos y de resistir las objetivaciones y las categorías a las que son sometidos por parte de los investigadores (Vasilachis de Gialdino, 2003). Como señalan Biglia y Bonet-Martí (2009), no se puede seguir dando voz a un sujeto subalternizado a la vez que se lleva a cabo un ejercicio de suplantación por parte de los científicos sociales, pues se seguirá colonizando al "otro en cuanto otro" y perpetuando la relación de poder entre el sujeto investigador y el sujeto investigado, que continuará siendo invisible desde un punto de vista epistémico.

Es por esto que en el estudio de los fenómenos migratorios es necesario incluir una pluralidad de voces e incorporar a la práctica investigadora distintos roles (investigador-investigado) que no impliquen estatus jerárquicos diferentes. La interacción cognitiva que se produce debe ser ubicada en un mismo nivel de forma que se logre superar la dicotomía, conceptual y discursiva, entre "sujeto conocido y sujeto cognoscente" (Vasilachis de Gialdino, 2003). El estudio de los fenómenos migratorios requiere producir nuevos mecanismos para poner en valor todas las formas de conocimiento y sobre todo el reconocimiento de la capacidad idéntica para conocer que poseen tanto el investigador como las personas que "colaboran" en la investigación (Ibid.). Reconocer la reflexividad y la capacidad para dar cuenta del sentido, del significado y razonabilidad de las acciones de estas personas es esencial para ir avanzando en la elaboración de nuevas epistemologías. Mientras no se reconozca la agencia de los propios migrantes se seguirá cayendo en procesos de dominación a través de la descripción y la categorización científica (Scheffler, 1981: 166). 


\section{Mecanismos de construcción de la diferencia}

Pasando a tratar los mecanismos de construcción de la diferencia que antes apuntábamos, debemos señalar que, pese a que la diversidad puede aprehenderse como una realidad que vertebra cualquier ámbito social y es condición inherente al género humano, con la llegada de población inmigrante, la diversidad ha seguido siendo entendida ahora en el espacio metropolitano- en términos de diferencia. Estas diferencias, no lo olvidemos, no dejan de ser artefactos elaborados para organizar la realidad de acuerdo a unos determinados patrones e intereses. Así tenemos que los elementos que se seleccionan para caracterizar la diversidad de la población migrante en términos de diferencia son constructos que posteriormente son validados $\mathrm{e}$ incorporados al imaginario social colectivo.

Siguiendo esta línea podemos explicar cómo las diferencias atribuidas a la diversidad son construidas socialmente, aunque se presenten, sin embargo, como naturalizadas o como un producto esencial de la cultura de determinados colectivos. Como exponen Berger y Luckman (2003: 147) podemos afirmar que "la realidad se define socialmente, pero las definiciones siempre se encarnan, vale decir, los individuos y grupos de individuos concretos sirven como definidores de la realidad. Para comprender en un momento dado el estado del universo construido socialmente o los cambios que sufre con el tiempo, es necesario comprender la organización social que permite a los definidores efectuar sus definiciones".

En el proceso que abarca desde la producción discursiva de determinadas ideas hasta que estas pasan a formar parte del imaginario social colectivo intervienen una serie de actores y son necesarios un conjunto de elementos para que finalmente un determinado discurso se incorpore a este imaginario. De esta forma, se evidencia que la "institucionalización" de los imaginarios es un elemento clave en este proceso, pues permite "objetivar" la realidad. Esto es posible gracias al hecho de que las instituciones, en este caso aquellas desde las cuales se produce la investigación sobre migraciones, principalmente universidades y centros de investigación, se caracteriza por su historicidad y capacidad de control social (Ibid., p. 74). La institucionalización de un imaginario, como es aquel elaborado en torno a la población inmigrante, nos sitúa en un entorno en el que los 
sujetos son alejados de la posibilidad de participar de su formulación siendo principalmente los investigadores quienes, despersonalizados por las siglas de su institución, elaboran los aspectos específicos que definen a estas personas y a su propia realidad. La legitimación de los imaginarios comienza, de esta forma, mediante la transmisión de un sistema de objetivaciones de la experiencia observada que se encuentra previamente condicionada por una serie de circunstancias que prácticamente la determinan. Las elaboraciones sobre los migrantes pueden ser o son, en este punto, construcciones rudimentarias y se reducen a esquemas explicativos o incluso a tipificaciones de comportamientos a partir de un imaginario colectivo dominante. En la medida que estas explicaciones sobre la realidad se consolidan, pasan a ser modelos explicativos que se constituyen como cuerpo de conocimiento que se legitiman y legitiman a quienes lo proponen. Finalmente, los conceptos elaborados sobre los sujetos migrantes se instalan en el universo simbólico, entendido como la matriz de todos los significados socialmente y subjetivamente reales. Así tenemos que, la observación de una serie de prácticas y roles que están de antemano condicionados por factores de naturaleza estructural, se constituyen como la base empírica desde la cual se conforman toda una serie de constructos que se institucionalizan y terminan por incorporarse al imaginario colectivo con carácter de realidad.

En este proceso de construcción de la realidad, las diferencias que son empleadas para representar la diversidad son constructos que no solamente se exponen, sino que simultáneamente se organizan produciendo un sistema jerárquico que representa en último término a determinados sujetos como superiores mientras que otros son inferiorizados. Es a través de estos procesos como la diversidad es articulada en una escala jerárquica que implica, esencialmente, una concepción desigual de las características de la diversidad. Así tenemos que "la construcción de la diferencia no es más que una nueva forma de presentar las distancias culturales, sociales y políticas que son legitimadas bajo la apariencia de ausencia de jerarquías sociales, pero que ocultan un refinado mecanismo de exclusión" (García Castaño et al., 1999: 17).

Entre los mecanismos de construcción de la diferencia que se señalan en la literatura y que afectan a los sujetos migrantes encontramos, en 
un primer nivel, aquellos que se basan en la elaboración de prejuicios y estereotipos (Ortiz, 2008) que redundan en generalizaciones, usualmente de carácter negativo, que tratan de justificar la realidad y que condicionan el trato que se les da a determinados sujetos. Por otro lado, tenemos los mecanismos enunciados por García Castaño et al. (1999: 20 y sig.) entre los que se mencionan aquellos de naturaleza epistemológica como son la construcción de categorías y taxonomías que permiten definir la realidad en unos determinados términos, o todos los procesos de economía cognitiva que tienden a simplificar y a generalizar las apreciaciones sobre la realidad; igualmente se encuentran los mecanismos históricos y discursivos que han redundado en procesos de racialización a través de las teorías del determinismo racial o del darwinismo social; en esta línea también tenemos la naturalización (biologización) de las diferencias culturales y que en determinados momentos hicieron referencia a cuestiones relativas a la inteligencia; y finalmente se presentan distintos mecanismos políticos e institucionales que tienen que ver con los procesos de escolarización, con política de vivienda o con cuestiones de precarización laboral.

La representación de la otredad, como señala Mary Nash (2003), es uno de los ejes de construcción social de la diferencia, del otro, del colectivo social diferente y que permite una ordenación jerárquica de las características que identifican al "nosotros" frente a los "otros". Estas representaciones sociales de la alteridad en el caso de la población migrante, suelen caracterizarse por ser relatos hegemónicos y homogenizadores en los que se oculta la diversidad que es condición de cualquier "otro" y en los que una de las partes se presenta como legitimada para establecer la representación. Igualmente, se merma la complejidad de una realidad social mediante el uso de categorías binarias (Godoy Peña, 2014: 41): nosotros/ellos, españoles/extranjeros, españoles/latinos, etc., que organizan los conjuntos sociales desde la clásica polarización dicotómica respecto de identidad/alteridad de un "otro" diferente y, como estamos apuntando, esencialmente inferior. Los intentos de grupismo (Brubaker, 2002: 169) son frecuentes en el ámbito de los estudios migratorios en los que existe la tendencia de crear grupos partiendo de meras categorías que en la práctica no se corresponden con agrupaciones reales (ej.: los ecuatorianos, a los que se le atribuye según 
el criterio de la nacionalidad una supuesta colectividad sin que puedan establecerse otro tipo de relaciones entre otras personas de nacionalidad ecuatoriana). Otras representaciones tienden a infravalorar el capital cultural por ser distinto al considerado 'español' (o a cualquier otro) y en otros casos las representaciones tienden a subalternizarlos e incluso a invisibilizar la presencia de estas personas negando así el reconocimiento y el valor de la diversidad en contextos escolares interculturales.

Los mecanismos de producción de la diferencia, así como las representaciones sociales de la población migrante en los procesos de investigación no conllevan una mera representación de la otredad como una imagen contrastativa de una mismidad ontológica a través de la cual nos representamos a nosotros mismos y podemos entender cómo estamos constituidos y quiénes somos (Hall, 1996: 473). Por el contrario, los procesos de diferenciación redundan en una suerte de inferiorización de determinados sujetos o colectivos que, no solo representados como diferentes, sino también como desiguales. Los mecanismos que intervienen son generalmente de naturaleza estructural y se encuentran incorporados tanto a las prácticas como a los discursos cotidianos que, al estar amparados institucionalmente, contribuyen al mantenimiento de un orden social y económico determinado. En el caso específico de las personas migrantes la identificación como sujetos etnificados favorece a la representación de "otro", no solo como 'diverso', sino también como desigual desde el punto de vista cultural, lingüístico, laboral, económico, social y personal.

Si bien debemos señalar que el estudio de los procesos de construcción de la diferencia en el ámbito de los estudios migratorios es de larga data, los mecanismos de alterización de la población migrante tienden a camuflarse y a sofisticarse, y sus efectos, aunque visibles en la mayoría de los casos, tienden a desligarse de sus causas (Wieviorka, 2009). Mediante estas reflexiones hemos querido dejar constancia de algunos problemas epistemológicos y metodológicos que frecuentemente se dan en los estudios migratorios y tienen ciertas consecuencias a la hora de establecer las conclusiones de dichos estudios. La práctica investigadora sobre migraciones es ciertamente compleja y los esfuerzos de los investigadores por aprehender esta realidad salvando 
todas las dificultades es un largo camino que muchos están dispuestos a recorrer como se ha puesto de manifiesto en esta obra colectiva.

\section{Sobre los autores y los capítulos}

Este libro tiene el privilegio de contar con más de diez investigadores e investigadoras que han realizado sus trabajos de campo en tres continentes -América Latina, Europa y África- y desde enfoques y perspectivas muy distintas, dejando en evidencia el carácter multi e interdisciplinar de los Estudios Migratorios. Dar voz a los sujetos, a los protagonistas de las migraciones, es una constante en esta serie de artículos, que pretenden, además, desenmascarar la retórica que desde el poder quiere imponerse en torno a un fenómeno, el migratorio, que es tan antiguo como lo es el propio ser humano. Poner en primera línea de las investigaciones realizadas el discurso y las prácticas racistas de los países de "acogida", así como subrayar la agencia del colectivo migrante, con toda la diversidad que alberga, es sin duda uno de los puntos fuertes de esta obra colectiva que nació con el objetivo de poner en cuestión la relación no siempre apacible entre migraciones y comunicación intercultural.

En el primer capítulo, Alberto Capote y Marta Zornoza, ambos de la Universidad de Granada, contribuyen con el trabajo "El cine como herramienta para analizar los procesos de aculturación en distintos contextos europeos. En él, plantean la importancia de analizar los filmes, no sólo como documentos que narran unos hechos que implica una mirada determinada, sino también como productos culturales, es decir, como testimonios de un momento concreto de la Historia y reflejo de las preocupaciones y aspiraciones de unos sujetos concretos en una época determinada (Ferro, 1980; Sorlín, 1985). En este caso, la vOz que inunda estos filmes analizados -Mi hermosa lavandería (Frears, 1985) con guion del escritor anglopakistaní Hanif Kureishi y Divinas (Benyamina, 2016) - es la de una generación de europeos, hijos de la migración y que se encuentran a medio camino entre la sociedad de sus padres, que le es ajena, y aquella en la que han nacido (Reino Unido y Francia), que no llega a aceptarlos completamente y en donde se enfrentarán a numerosos obstáculos para poder alcanzar parcialmente sus metas. 
La importancia de este trabajo radica en la presentación de un esquema de análisis para trabajar con películas en el ámbito educativo que permite, por un lado, reflejar los procesos de aculturación de las sociedades migrantes y/o racializadas y, por otro lado, los estigmas y las opresiones raciales que sufre una parte de la sociedad que es pensada desde el poder en términos de otredad. Los dos ejemplos analizados, además, cuentan con la ventaja de estar ambientados en dos países con modelos de gestión de la diversidad muy diferentes como son el británico y el francés que, con sus pros y sus contras, han demostrado ser incapaces, ambas, de acabar con la exclusión económica, política y social de los migrantes y sus vástagos. Analizar esto en el aula será más fácil gracias a esta magnífica aportación que se nutre de una mirada crítica desde la Antropología y la Geografía Humana.

Y si bien la gran pantalla tiene una importancia fundamental para construir y deconstruir representaciones sociales, más influyente aún resulta la televisión. En este punto nos detenemos en el capítulo de Xavier Brito Alvarado y Nelly Guamán Guadalina de la Universidad Técnica de Ambato, titulado "Entretenimiento y el espectáculo como discursos televisivos". Los profesores ecuatorianos construyen su trabajo en torno a las ideas de la importancia de la televisión debido a su formato, ideal para el consumo en el hogar, la capacidad del entretenimiento como elemento de distracción y objeto comercial y, ligar todo el espectáculo que está ligado al entretenimiento y que consumimos por la televisión a las representaciones que se conforman a través de esta plataforma para con las migraciones.

Una de las ideas más interesantes que señalan es la de que, si bien se critica lo vacío de una sociedad volcada al consumo y que es capaz de consumir televisivamente sus propias desgracias a través del espectáculo, también ha sido y es posible hacer de los discursos televisivos sobre la migración un instrumento pedagógico para los migrantes o para aquellos y aquellas que tienen pensado migrar. Sin duda es un tema abierto al debate, ya que la inmensa mayoría de consumo televisivo en países empobrecidos presentan una realidad deformada de ciertos países, como si de El Dorado se tratase, haciendo de polo de atracción para una juventud que no sabe exactamente que hay más allá de emprender un viaje arriesgado que no tiene, ni mucho 
menos, una recompensa asegurada (Inongo-vi-Makomé, 2017). También se aborda la mirada negativa que se proyecta de la migración ¿están soplando nuevos vientos también en el espacio televisivo?

De la Università di Cagliari, Italia, Gianluca Gaias nos introduce en un estudio "Territorialización 2.0.: la red en los procesos migratorios y los social networks al servicio de las comunidades" en el que se pone de manifiesto nuevas formas de comunicación que escapan de las lógicas tradicionales y que se llevan a cabo a través de las redes sociales de Internet y que suponen una autorrepresentación espacial y pública de colectivos migrantes y, a su vez, de apropiarse de este espacio "virtual". Sin duda, estamos ante un estudio que pone el acento en la capacidad de agencia, en este caso particular, del de la comunidad senegalesa mouride de Cerdeña. Ya no sólo se modifica el espacio urbano a través de sonidos, colores y olores, sino que también se introducen cambio a través de la migración en el espacio virtual en la búsqueda de una estrategia de construcción territorial, de exploración de nuevos lugares en los que puedan desarrollarse estrategias de solidaridad, darse a conocer entre las otras comunidades o, como medio simbólico que sirva como plataforma para los nuevos migrantes de la comunidad senegalesa en Cerdeña.

Siguiendo a autores como Vázquez y Knott (2014) o Giorda (2015), Gianluca Gaias complejiza la mirada simple y estereotipada que existe en Occidente con respecto a las migraciones africanas atendiendo a cómo la comunidad de los mouride senegaleses de Touba construye territorio en la diáspora a través de las redes sociales. Además, estos no lo hacen en wolof, la lengua nativa de este colectivo, sino en italiano, como muestra de apertura ante la sociedad sarda y para las nuevas generaciones nacidas en Italia producto de la migración. Ahora ya podemos, no sólo decir que ese sur italiano ha dejado de tener ese componente exclusivamente ligado a la emigración, sino que esa recepción de inmigrantes ocupa también el espacio virtual en busca de lugares desde los que proyectar visibilidad, reconocimiento y construir comunidad.

El siguiente texto "Usos de las lenguas y preferencias lingüísticas entre los inmigrantes refugiados" de las investigadoras del Instituto de Migraciones de la Universidad de Granada, Rosella Bianco y Mónica Ortiz Cobo se centran en la importancia que tiene la lengua en la 
creación de identidades para los colectivos de migrantes y refugiados. A partir de un estudio de caso en Salento, en la región de Apulia, Italia, y en el espacio escolar, el artículo indaga en las distintas actitudes del alumnado refugiado y migrante para con su lengua materna. Es muy interesante el hecho de mostrar la diversidad del alumnado no nacional, que tiende a ser pensado e imaginado como un bloque monolítico, así como a su posicionamiento respecto a la lengua de acogida, en este caso el italiano, y a la lengua materna, que estará íntimamente ligada a las experiencias vitales de estas poblaciones antes de llegar a Europa. Serán aquí las distintas necesidades de los colectivos lo que marcarán las preferencias lingüísticas particulares, sin obviar que la lengua dominante en este caso, el italiano, es imprescindible de cara a obtener un trabajo, de relacionarse con las instituciones o para obtener un permiso para residir de manera regular en Italia.

El trabajo de Alessandra Cama se centrará en el discurso del profesorado sobre alumnado en la escuela italiana, poniendo de relieve el lenguaje gubernamental a través de los textos ministeriales y problematizando una serie de conceptos como el de "menores migrantes" o "menores extranjeros" que no hacen sino esconder la diversidad y la complejidad de la realidad de las aulas en Italia. A través de una serie de entrevistas en profundidad a docentes italianos en Messina (Sicilia, Italia) su trabajo nos mostrará la necesidad de apostar por un cambio de paradigma que apueste por cuestionar y problematizar cómo se ha construido el "nosotros" y deje de pensar en el "otro" como fuente de problemas.

Amaia Garcia-Azpuru, profesora de la Escuela Universitaria de la Cámara de Bilbao nos presenta un trabajo que tiene como objetivo analizar el desconocimiento que aún existe en la sociedad con respecto a los conceptos que utilizamos en el ámbito de las migraciones y la influencia que en ello ejercen los medios de comunicación. En este caso concreto y a través del trabajo "El condicionante de la terminología en el caso de las migraciones", Amaia se centrará en el aspecto terminológico (en los conceptos de inmigrante y extranjero) mostrándonos los resultados de un estudio que arranca desde 2009 y que se apoya en los resultados de más de ciento cuarenta encuestas realizadas en tres centros educativos de la Comunidad Autónoma de 
Euskadi (CAE) y en un rastreo de noticias en donde estos conceptos son relevantes.

La importancia de este estudio radica en poner de manifiesto, por un lado, el desconocimiento que tiene la sociedad vasca $-y$ que podríamos hace extensible a todo el país- sobre un fenómeno, el de la migración, que ya no es nuevo en España pese a que tradicionalmente ha sido una tierra de emigración. Que exista una confusión entre extranjero y migrante puede conllevar a que, desde el lenguaje común, se establezcan elementos de exclusión aún más fuertes. Por otro lado, es fundamental ser consciente del papel que juegan los medios de comunicación en la conformación de una "opinión pública" que puede ser negativa o positiva con respecto a estos colectivos. Es por ello que en este trabajo se analizan casi cinco mil noticias de diversos medios de comunicación de gran difusión como El País, El Mundo, Antena 3, EITB o Telecinco entre otros. Los resultados son reveladores de cómo la asociación de un estatus socioeconómico está muy ligado a una mayor o menor consideración negativa de determinados colectivos a través de estos dos conceptos clave analizados.

El siguiente trabajo "Las lenguas de la comunicación de las trabajadoras domésticas filipinas de Mesina" de Maria Cama aborda la cuestión de las lenguas de las trabajadoras "extranjeras inmigrantes" a través de un estudio sobre las prácticas lingüísticas de un grupo de mujeres filipinas que viven en una ciudad siciliana de Mesina, en Italia. La situación de este colectivo se caracteriza por una serie de particularidades como el aislamiento y la invisibilidad que sufren, al que se enfrentan con unas potentes redes de solidaridad, por lo feminizado que está su sector laboral, por la importancia que juegan instituciones como la Iglesia católica en su proceso migratorio o su exposición a relaciones desiguales de poder constantemente. El análisis de estas situaciones es muy importante, pues se pone el acento en un grupo muy vulnerable y que se ve cómo, a causa de su trabajo, le es muy difícil aprender la lengua italiana, fundamental para poder realizar un trabajo equivalente a la cualificación profesional que tienen. Sin duda un trabajo que nos sitúa en realidades y contexto diferentes que se viven en otras geografías mediterráneas de la Unión Europea.

La profesora de Antropología Social de la Universidad de Granada, Ariet Castillo Fernández, nos presenta un trabajo en el que se liga la 
creación institucional de datos desde el Instituto Nacional de Estadística y la transformación que hacen de estos datos los dos periódicos con más influencia según el Oficina de Justificación de la Difusión (OJD): El País y El Mundo. Poner de manifiesto esa "fabricación del consenso" para "domesticar al rebaño perplejo" a través de la simplificación del discurso y su transformación en mercancía de la que habla Noam Comsky (2002, 13-14) ligado a la representación del "otro" en negativo, en este caso las personas ligadas a la migración, es una de las tareas que se propone Ariet en este estudio.

El capítulo tiene una relevancia tremenda pues esa representación del "otro" no esconde sino una autorrepresentación del "nosotros", un "nosotros" entendido en términos de normalidad y que se ejerce desde una posición de poder. Ya nos avisaba Roger Silverstone (2010: 59), y es que estas prácticas de representación del otro en negativo no son sino "la punta del iceberg de un discurso moral omnipresente en las diversas prácticas de representación de los medios modernos" (Silverstone, 2010: 59) que desgraciadamente, de forma negativa acaban "influyendo en nuestro comportamiento cotidiano" (Muñoz, 2012: 13). Una obligada lectura que abarca un tema poco tratado a través de las notas de prensa de una institución aparentemente "neutral".

El siguiente capítulo, "Espacios de paz en las trayectorias migratorias de la población subsaharianas que llega a Melilla” de la investigadora Rocío González Rey nos muestra una realidad poco o nada conocida en nuestro país sobre el proceso migratorio y es aquello que hay antes de los mediatizados y estigmatizados "saltos a la valla". Realizado desde los Estudios de Paz y a través de numerosas entrevistas realizadas en el continente africano, Rocío tiene la habilidad de ponernos ante el espejo: nos enfrenta contra el profundo desconocimiento de una sociedad ante el fenómeno migratorio y los propios migrantes, a los que hemos deshumanizado desde los discursos de los medios de comunicación de masas (Fajardo y Soriano, 2017) hasta desde los discursos y prácticas que invaden nuestra propia cotidianeidad (Pineda, 2016).

A través de conceptos como el de "paz imperfecta" (Muñoz, 2001), la investigadora intenta responder a la siguiente cuestión: ¿cuáles son los espacios de paz que surgen durante un proceso migratorio minado, 
entre otras cosas, de una continua opresión racista que está institucionalizada? Y si bien en este trabajo también se señalan aspectos como la violencia intercomunitaria, no menos cierto es el énfasis en subrayar aspectos fundamentales como las redes de solidaridad entre los propios migrantes. Sin duda, una de las virtudes de este trabajo es la capacidad de mostrar la voz de los propios migrantes y de personas que trabajan de cerca relacionados con este fenómeno desde una perspectiva crítica. Un trabajo que viene a colmar un vacío en el ámbito de las investigaciones sobre migraciones. Una enorme aportación con el que tenemos el placer de contar en esta obra colectiva.

Por último, el estudio "El "Italiano L2" en la escuela italiana: perspectivas de los profesionales de la escuela y del alumnado extranjero en las escuelas secundaria de segundo grado en Palermo" de Vincenza Indelicato nos presenta una nueva política italiana de tratar el tema del aprendizaje del italiano por parte del alumnado extranjero, que es a través de la asignatura de italiano como "lengua extranjera para el estudiantado extranjero" y la recepción que ha tenido este nuevo hecho político entre el propio alumnado extranjero y entre los profesionales que la imparten. A través de entrevistas "cara a cara", observación participante y técnicas como el "focus group" o "preguntas sonda" queda patente la existencia de toda una serie de cuestiones pendientes en la mejora de la legislación y de las prácticas de enseñanza-aprendizaje que tengan efectos más positivos para alumnado.

Como se ha puesto de manifiesto, el eje sobre el que se articulan todas estas obras es el de la realidad migratoria que se desarrolla en muy distintos contextos y circunstancias, y en la necesidad de aprehender los fenómenos sociales, políticos, culturales o económicos que acontecen cuando las poblaciones se mueven.

\section{Bibliografía}

Berger, P. L. y Luckmann, T. (2003). La construcción social de la realidad. 18th ed. Buenos Aires: Amorrortu Editores.

Biglia, B., y Bonet-Martí, J. (2009). La construcción de narrativas como método de investigación psico-social. Prácticas de escritura compartida. Forum: Qualitative Social Research, 10(1). 
Brubaker, R. (2002). Ethnicity without groups. Archives Européennes de Sociologie, XLIII, 2, p. 163-189.

Brubaker, R.; Cooper, F. (2000). Beyond "identity". Theory and society, 29, 1-47.

Chomsky, N. (2002). "El control de los medios de comunicación", en Chomsky, N. y Ramonet I. (Eds.). Cómo nos venden la moto. Información, poder y concentración de medios. Barcelona: Icaria.

Davis, K. (1988). Social Science Approaches to International Migration. En M.S. Teitelbaum y J.M. Winter (eds.), Population and Resources in Western Intellectual Traditions, p. 245-261. New York: The Population Council.

Díaz de Rada, A. (2010) Cultura, antropología y otras tonterías. Trotta: Madrid.

Fajardo Fernández R. y Soriano Miras, R.M. (2016). "La construcción mediática de la migración en el Mediterráneo: ¿no-ciudadanía en la prensa española?". Revista Internacional de Estudios Migratorios, Vol.6(1), 141-169.

Ferro, M. (1980). Cine e historia. Barcelona: Editorial Gustavo Gili. García Castaño, F. J., Granados Martínez, A. y Pulido Moyano, R. A. (1999). Reflexiones en diversos ámbitos de construcción de la diferencia. En F. J. García Castaño y A. Granados Martínez (Eds.), Lecturas para educación intercultural, pp. 15-46. Madrid: Editorial Trotta.

Giorda M. C., (2015) "I luoghi religiosi a Torino. Le religioni nei contesti urbani contemporanei", Quaderni di diritto e politica ecclesiastica, 2(8), 339-358;

Godoy Peña, L. (2014). Hacia una posible epistemología de las diferencias en contextos educativos. Investigación y Postgrado, Vol. 29(2), 2014 pp. 35-59.

Grosfoguel, R. (2012). El concepto de "racismo" en Michel Foucault y Frantz Fanon: ¿teorizar desde la zona del ser o desde la zona del no-ser?. Tabula Rasa, 16, 79-102.

Hall, S. (1996). What is "black" in popular culture. En D. Morley y K. H. Chen (Eds.), Stuart Hall. Critical Dialogues in Cultural Studies, pp. 465-475, Londres: Routledge.

Inongo-vi-Makomè, (2017). Visión del mundo de un africano desde ¿El Edén? Barcelona: Ediciones Carena. 
Muñoz, F. A. (2001). La Paz imperfecta. Granada: Eirene.

Muñoz, F. A. (2012). "Prólogo". En Cortés González A. y García López, M. (eds.). Comunicación y Cultura de Paz. Granada: Eirene.

Nash, M. (2003). Representaciones culturales y discursos de género, raza y clase en la construcción de la sociedad europea contemporánea. En: Mary Nash y Diana Marre (eds.). El desafío de la diferencia: representaciones culturales e identidades de género, raza y clase, pp. 21-36. Bilbao: Universidad del País Vasco, Euskal Erico Unibertsitatea.

Ortiz Cobo, M. (2008). Inmigración en las aulas: percepciones prejuiciosas de los docentes. Papers: Revista de Sociología, $\mathrm{n}^{\circ}$ 87, 2008, 253-268.

Pineda, E. (2016). "Discriminación racial y vida cotidiana en América Latina: empleo, educación y medios de comunicación". Revista Venezolana de Análisis de Coyuntura, 22(2), 121-144

Rodrigo Alsina, M. y Gaya Morla, C. (2001). Medios de comunicación e interculturalidad. Cuadernos de información, 14, 105-110.

Scheffler, T. (1981). The ideology of binary opposition:

Subject/object Duality and Anthropology. Dialectical Anthropology, 6 (2), 165-169.

Silverstone, R. (2010). La moral de los medios de comunicación. Sobre el nacimiento de la polis de los medios. Buenos Aires: Amorrortu.

Sorlin, P. (1985). Sociología del cine. La apertura para la historia de mañana. México: Fondo de Cultura Económica.

Sousa Santos, B. de (2011). Introducción: las epistemologías del sur. En VV.AA. Formas-Otras: Saber, nombrar, narrar, hacer, p. 1122. Col. Monografías. Barcelona: CIDOB.

Vasilachis De Gialdino, I. (2003b). Propuesta epistemológica y metodológica para el estudio de los pobres, de la pobreza y de la identidad. En Pobres, pobreza, identidad y representaciones sociales (pp. 19-48).

Vazquez, M.A., y Knott, K. (2014). Three dimension of religious place making in diaspora, Global Networks, 14(3) 326-347. Wieviorka, M. (2009). El racismo. Una introducción. Barcelona: Gedisa. 



\title{
El cine como herramienta para analizar los procesos de aculturación en distintos contextos europeos
}

\author{
Alberto Capote Lama \\ Universidad de Granada, España \\ Marta Zornoza Madrid \\ Universidad de Granada, España
}

\section{Resumen}

El cine ha ido adquiriendo cada vez mayor fuerza como objeto de análisis en las Ciencias Sociales. Los movimientos migratorios ha sido uno de los temas más abordados, incluyendo en España donde ha ido creciendo la bibliografía. La posibilidad de este capítulo surgió en clase de la asignatura Migraciones y Educación que se imparte en el Grado de Antropología de la Universidad de Granada. El objetivo ha sido crear un esquema de análisis para analizar películas que reflejen los procesos de aculturación en distintos contextos europeos. Para ello integramos distintos conceptos desde la Geografía Social y la Antropología para abordar los procesos migratorios: espacio de vida, aculturación, itinerario migratorio, ciclo migratorio, etc. A modo de ilustración se presenta un análisis siguiendo este esquema de dos películas en dos contextos distintos: "Mi hermosa lavandería", en el Reino Unido de Margaret Thatcher de los años ochenta y "Divinas", en Francia en la actualidad. En las dos películas los protagonistas son jóvenes descendientes de la inmigración. 
Palabras clave: cine, inmigración, aculturación, espacio de vida, Europa

\section{Introducción}

— L CINE de ficción como soporte para estudiar los movimientos 1 migratorios ha sido una tentación que ha estado bastante presente en las Ciencias Sociales, pero no ha sido hasta hace relativamente poco tiempo que su interés ha ido creciendo cada vez más (Alonso Seoane, 2012). La atracción, quizás, pueda resultar incluso más novedosa en el caso español debido a que no ha sido hasta hace apenas veinte años que la inmigración ha pasado a constituir una de las principales características de la sociedad española. De hecho, se suele destacar lo poco que se ha estudiado cómo el cine español abordó el exilio y la emigración española durante mucho tiempo (Berger y Komori, 2011). Sin embargo, a partir de los noventa sí empiezan a surgir distintas propuestas interesadas tanto en examinar como el cine ha reflejado la llegada de inmigrantes a España, así como, incluso, analizar cómo se retrató la emigración española a Europa o dentro del Estado durante el franquismo (Santaolalla, 2005; Maroto y López, 2018)

Las temáticas abordadas han sido muy variadas. Galiano León (2008) enumera un listado bastante amplio de parámetros que han sido tratados en la producción cinematográfica tanto nacional como extranjera: la incorporación del inmigrante en el mercado de trabajo, la evolución de la incorporación de la mujer en los flujos migratorios, el racismo y la xenofobia, la construcción de la interculturalidad, etc., por citar algunos de ellos. Los géneros también han sido muy variados: desde el drama hasta la comedia, pasando el thriller. Una cuestión muy frecuente ha sido plantearse hasta qué punto el cine de ficción puede ser considerado un soporte para conocer una realidad histórica o un análisis social de un determinado momento. Para Moyano (2016), el discurso cinematográfico forma parte de la herencia cultural de un país y por tanto también ha jugado un papel destacado en la interpretación de los procesos migratorios. Es decir, además de su visión más o menos cercana de la realidad, también interesa qué óptica se ha querido plasmar en cada momento y según cada autor. Alonso Seoane (2012), en su estudio sobre el cine español, destaca que los discursos cinematográficos sobre las migraciones están marcados por el discurso 
dominante del poder, ya que los utiliza como mensaje para concienciar según determinadas pretensiones.

En efecto, cada obra no deja de ser una visión parcial y subjetiva de su creador y en un contexto determinado. Dicho de otro modo, cada película representa un medio de transmisión de una tesis o una perspectiva que quieren compartir con el resto de la sociedad (Vallejo Peña, 2014: 4). Como Galiano León (2008: 173) subraya "el cine selecciona aquellas imágenes y temas que deben ser mostradas o las que deben ser ocultadas". A modo de ilustración, recuerda que la inmigración procedente de las excolonias con destino a la Francia de los treinta gloriosos o de turcos hacia Alemania apenas fue abordada durante muchos años o se hizo con visiones muy estereotipadas. No ha sido hasta la llegada de los descendientes de esta inmigración a la edad adulta cuando han dado voz a esta parte de la historia desde otra perspectiva. En este sentido, la (erróneamente) denominada "segunda generación" comienza a aparecer como uno de los sujetos más reflejados en el cine reciente sobre las migraciones. Incluso en estos casos las cuestiones relacionadas con la inmigración aparecen representadas como problemas, fuente de conflicto o controversias, contribuyendo a construir una otredad, donde también se incluye a los descendientes de las familias inmigrantes nacidos en el país de acogida (Saeed, 2007).

En efecto, en países con una larga trayectoria migratoria, como por ejemplo Francia, Alemania o Reino Unido, casi se podría establecer una línea divisoria en la filmografía sobre la inmigración en función de los vínculos de sus autores con los procesos migratorios. Así, para el caso alemán, por ejemplo, Türkmen (2000) distingue entre el cine que reflejó la llegada de inmigrantes en los años 70 y 80, realizado sobre todo por autores alemanes, con el que surgió muchos después y que denomina "cine de mestizaje" o "cine híbrido", ya que algunos de estos nuevos realizadores son de alguna manera descendientes de la inmigración. Según esta autora, estos nuevos directores cuestionan cómo se había reflejado en el cine la llegada de inmigrantes a Alemania: con un discurso cargado de estereotipos y con una imagen del inmigrado como una persona explotada e incapaz de reaccionar para cambiar su suerte. A conclusiones similares llega Yahi (2007) en lo que se refiere al cine francés. En un primer momento, los argelinos 
aparecen como el paradigma del inmigrante en Francia: una persona en una situación de vulnerabilidad pero que asume pasivamente su destino. El objetivo ante todo era mostrar las condiciones de penuria en la acogida de esta población. Sin embargo, posteriormente, el enfoque se diversifica: son los propios inmigrantes o sus descendientes los que toman la palabra y lo hacen adoptando otros puntos de vista. En años recientes, la autora distingue dos tendencias en el cine francés: por una parte, ilustrar las nuevas olas migratorias y, por otra, retratar la historia política de la inmigración en Francia.

López-Campos Bodineau (2012) en un análisis sobre el cine francés y quebequense también pone de relieve como en los últimos años la denominada "segunda generación" ha ido ocupando mayor protagonismo. En un primer momento el cine reflejó los duros comienzos, sobre todo de los padres. Más tarde el objetivo era mostrar el dilema de la integración y la asimilación de los hijos nacidos o criados en Francia o Quebec. Ahora bien, la autora también señala importantes puntos divergentes entre los dos países: en las películas realizadas en Quebec el problema de la integración aparece menos reflejado, lo que se explicaría por una legislación orientada hacia un modelo de sociedad multicultural. En cambio, en Francia la dualidad o el debate sobre la identidad de los descendientes de la inmigración sí pasa a ser uno de los elementos clave en su cine: cuando se es tratado como extranjero en el país de nacimiento y al mismo tiempo como foráneo en el país de origen de los padres.

Nuestro objetivo es presentar una herramienta pedagógica para utilizar el cine como soporte para reflexionar sobre el reflejo en la vida cotidiana de los procesos de aculturación en distintos contextos europeos. La idea ha surgido en el marco de la asignatura Migraciones y Educación que se imparte en el grado de Antropología de la Universidad de Granada. Uno de los temas tratados gira en torno a los distintos enfoques adoptados sobre las sociedades pluriculturales en Europa y cómo se traducen en los procesos de aculturación. Los modelos sobre la gestión de la diversidad que más se discutieron fueron el británico y el francés, los cuales suelen ser presentados a menudo como antagónicos o, en todo caso, muy distintos. Nos pareció especialmente interesante qué elementos sobre la vida cotidiana se reflejaban como divergentes y si se detectaban puntos de encuentro. 
La propuesta pretende, de este modo, repasar algunos conceptos claves en el análisis de las migraciones para estudiantes tanto de Geografía Humana, como de Antropología u otras disciplinas.

El modelo británico suele ser presentado como abierto y algunas características con las que se define son: el reconocimiento explícito de minorías étnicas a las que se les pretende proporcionar una igualdad de oportunidades y no solo de derechos (Rea y Tripier, 2009). De este modo, las políticas públicas se han orientado hacia la puesta en marcha de medidas de discriminación positiva (por ejemplo, representación étnica en el empleo público) o de preservación de las identidades, incluyendo a los descendientes, así como de alerta sobre posibles conductas racistas. Esta promoción de la diversidad fue tal que, como recuerda Eychenne (2017), cuando los hindúes llegaron a Reino Unido casi se diría que los poderes públicos los animaron a reproducir las divisiones endogrupales propias de la comunidad sud-asiática. En resumen, en el modelo británico el comunitarismo es una característica intrínseca. El riesgo aquí se sitúa en una segregación y aislamiento de las distintas comunidades en sus parcelas, además de mayores obstáculos para acceder a determinadas esferas de la sociedad.

En lo que respecta al modelo francés, parte de tres principios (Rea y Tripier, 2009): la separación ente la esfera pública y la privada; la primacía de los derechos individuales sobre los colectivos; y la laicidad, como requisito para hacer a todas las personas iguales ante la nación y el Estado trascendiendo todas las pertenencias individuales (culturales, religiosas, sociales, económicas, etc.). Así, en el francés no se promueve la representación comunitaria en el espacio público por identidades de tipo religioso o étnico. Para el historiador francés Gerard Noiriel (2017), durante el siglo XX, a diferencia de otros países del entorno en Francia solo se mantuvieron dos registros: el componente social (lucha de clases) o ser nacional o extranjero. Así, la adquisición de la nacionalidad ha ocupado una plaza esencial en el debate y gestión pública francesa y entre los inmigrados, aunque con un sentido distinto según la época: como necesaria durante las políticas natalistas o como de prueba durante 10 años a finales del siglo pasado.

El capítulo se estructura en tres partes. En primer lugar, presentamos nuestro esquema pedagógico para analizar las películas desde el punto de vista de la gestión de la diversidad en distintos contextos estatales y 
cómo aparece retratada en la vida cotidiana. A continuación, aplicamos dicho esquema a las dos películas que se han seleccionado para esta ocasión: en Reino Unido "Mi hermosa lavandería" (1985), de Stephen Frears, y en Francia, más reciente, "Divinas" (2016), de Houda Benyamina. Más adelante se explicará los motivos que han orientado la elección de las dos películas. En un tercer punto hacemos las conclusiones adoptando un punto de vista comparativo de las dos películas.

\section{Metodología: una propuesta de análisis de los procesos de aculturación en distintos contextos europeos}

El esquema se compone de cuatro partes. Como hemos dicho, surgió en el marco de la asignatura Migraciones y Educación que se imparte en el Grado de Antropología de la Universidad de Granada. El esquema de análisis que hemos elaborado adopta un enfoque interdisciplinar: adoptamos parámetros propios de la Geografía Social (por ejemplo, el concepto de itinerario migratorio o espacio de vida), de la Antropología (aculturación) e incluso de la Historia. Como se ha señalado en la introducción, se trata de incluir distintos conceptos de base en el estudio de las migraciones que puedan ser de interés para los estudiantes.

\section{a) E1 contexto}

Distinguimos entre el contexto en el que desarrolla la historia de la película y el del momento en que se realizó, ya los dos no tienen por qué coincidir. Sobre todo, nos interesa conocer los hechos y los discursos sobre la inmigración en ese momento concreto.

\section{b) Geografía de las migraciones y proyectos migratorios}

Aquí se trata de describir el itinerario migratorio de nuestros protagonistas, en el que se incluye: el país de origen, los posibles lugares de tránsito y el de residencia actual. Cuando hablamos de itinerario no solo hacemos referencia al detalle de los lugares de residencia, sino también a los vínculos que se detectan con cada uno de estos lugares (Robin, 2017). Es decir, que representan en las vidas de nuestros protagonistas los espacios de la migración. Así la información que se podría incluir aquí sería: el lugar de origen, los distintos espacios de tránsito y el actual lugar de residencia. Además, incorporamos el tipo de migración en función de cuál fue o fueron los motivos para emigrar. 


\section{c) Perfiles y ciclo migratorio}

En este punto presentamos las características principales (sexo, edad, nivel de formación, estado civil, etc.) y las características del hogar en el país de residencia (si viven en familia, solos, con otros compatriotas, hogares mixtos, etc.). También señalar en qué figura se centra la película: los padres, los descendientes, personas sin vínculos familiares, etc.

Aquí también es interesante analizar en qué fase del proyecto migratorio se encuentran los protagonistas de nuestra historia. Expresado de otro modo, si se trata de personas recién llegadas o ya con un periplo de vida en el país de acogida. Volvemos a recuperar la dimensión temporal. Para ello podemos tomar como referencia la clasificación que hicieron Bastenier y Dassetotto (1995) del ciclo migratorio en la vida de un inmigrado que reflejan su grado de arraigo. Distinguen tres momentos: una primera fase caracterizada por la precariedad laboral y social, acompañada a menudo por una notable movilidad geográfica; en segundo lugar, el inmigrado ha alcanzado cierta estabilidad laboral y residencial, coincidiendo además con la formación de una familia en el nuevo hogar; en una tercera fase, los signos de arraigo son aún más evidentes e incluyen a los descendientes. En estos casos la vida en la sociedad de acogida aparece normalizada y el país de origen aparece como una referencia cada vez más lejana.

\section{d) Análisis de los procesos de aculturación en la vida cotidiana}

Se trata del bloque principal del análisis. Para examinar cómo se manifiestan los procesos de aculturación en la vida cotidiana hemos hecho recurso, en primer lugar, al concepto de espacio de vida del demógrafo francés Daniel Courgeau (1980: 17): porción del espacio en la que una persona efectúa todas sus actividades. Aquí no solo se incluyen los lugares de permanencia y de tránsito, sino también todos aquellos con los que mantienen vínculos. Para intentar abordarlo mejor, Courgeau incluye las siguientes esferas: el lugar de trabajo, el cual junto al hogar constituye los dos principales polos en la vida de una persona; las relaciones sociales, donde se incluyen desde las familiares hasta las del círculo de amigos. El análisis del espacio de vida nos lleva directamente a examinar el grado de segregación de las personas que protagonizan la historia, así como las características del 
proceso de aculturación: mayor o menor contacto con la población autóctona, de qué tipo, dónde, etc.

Por otra parte, también interesa conocer cómo viven su identidad o su posición en la sociedad de acogida los protagonistas con vínculos migratorios en relación con: por un lago, lo que se entiende que es su cultura de origen, es decir, el país de nacimiento o el país de procedencia de los padres si se trata de los descendientes; por otro, en lo que se refiere a la cultura del grupo mayoritario. Dicho de otro modo, donde lo situamos en el proceso de aculturación. Entendemos dicho proceso tal y como lo definía Barfield (2001) en su Diccionario de Antropología:

Es el proceso de cambio cultural que se desencadena a raíz del encuentro o contacto entre dos sistemas culturales autónomos, y que produce un aumento de las semejanzas entre ambos. Siempre implica un proceso complejo de interacción con procesos sociales concomitantes, cuyos parámetros se expusieron con rigor en dos importantes memorandas por encargo del Consejo de Investigación en Ciencias Sociales. En este tipo de conjunción de culturas, la cultura donante puede no presentar la totalidad de sus elementos culturales, y el propio sistema de valores de la cultura receptora actúa a veces cribando o modificando algunos de esos valores.

El modelo más conocido sobre los distintos tipos de aculturación es el de John Berry (2003). El autor distingue cuatro actitudes ante la aculturación en función del grado de relación con la cultura del grupo receptor y con la de origen. Así, distingue cuatro tipos de procesos: modelo de integración, cuando se llega a una situación de equilibrio; asimilación, cuando tiene lugar un abandono de la cultura de origen y una absorción total en la de recepción; segregación o separación, se desea y puede mantener la identidad y tradiciones del grupo de origen, pero separados del grupo mayoritario; y finalmente, la exclusión, cuando la persona perteneciente al grupo minoritario pierde el contacto cultural y psicológico tanto con la sociedad de origen como la receptora. Como es sabido, se suele asociar el modelo británico con prácticas de segregación y al francés, con la asimilación. 
No obstante, para circunscribir el análisis exclusivamente a contrastes culturales que soslayan las diferencias sociales, pensamos que es también conveniente hacer referencia a la posición social de nuestros protagonistas: si trabajan o no, en qué condiciones, si se aprecian signos de movilidad social ascendente o descendente, etc.

En resumen, nuestra propuesta consiste en realizar un esquema dirigido a estudiantes que permita abordar a través del cine de ficción los conceptos y problemáticas más comunes sobre las migraciones internacionales con un enfoque interdisciplinar. Se ha resumido en el esquema siguiente:

Figura1. Esquema de análisis: cine y procesos de aculturación

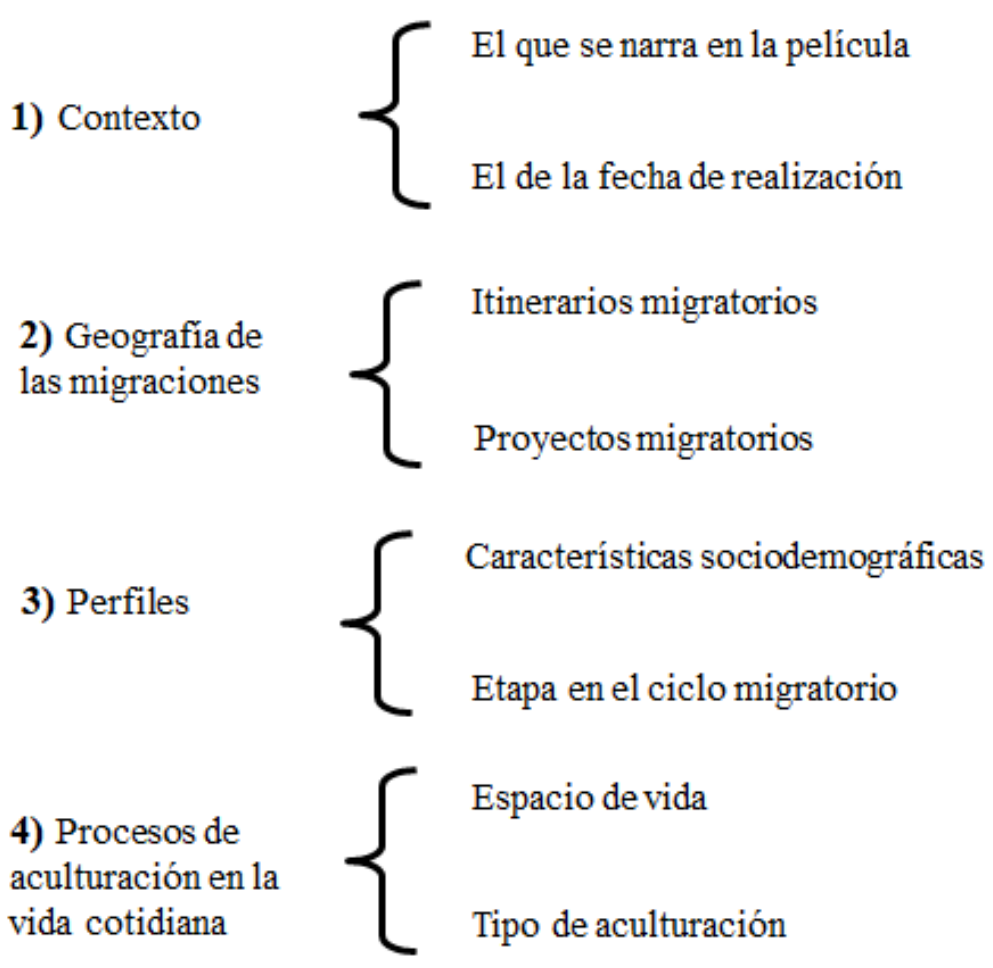

Fuente: elaboración propia

\section{A modo de ilustración: "Mi hermosa lavandería" (Reino Unido) y "Divinas" (Francia)}

¿Por qué se han seleccionado estas dos películas? Por presentar varios aspectos en común pese a estar rodadas en países y momentos distintos. El primer elemento que tuvimos en cuenta es que fuesen producciones en las que sus autores o autoras tuviesen algún vínculo 
con la inmigración, bien porque ellos lo fuesen o por ser descendientes de familias inmigrantes. Así, "Mi hermosa lavandería" está realizada por un director inglés, Stephen Frears, pero el guión es de Hanif Kureishi escritor anglopakistaní; "Divinas" es la primera película de una joven directora franco-marroquí. En segundo lugar, en los dos casos los primeros protagonistas son descendientes de la inmigración: han nacido en Reino Unido y Francia, pero, a menudo, son percibidos como extranjeros. En tercer lugar, que la historia transcurriese en alguna urbe europea para examinar el tema de la segregación residencial y facilitar la comparación: en un caso se trata de Londres y en el otro de París.

\section{Mi hermosa lavandería, de Stephen Frears (Reino Unido, 1985)}

La película versa en torno a Omar, joven de origen pakistaní que reside en Londres junto a su padre e intenta abrirse camino después del fallecimiento de la madre. Tras abandonar los estudios, es contratado por su tío Nasser en uno de los múltiples negocios que posee: una lavandería. Contrata a un antiguo compañero de colegio inglés con el que acabará iniciando una historia de amor. En su búsqueda por crecer, Omar se moverá entre los consejos contrapuestos de su padre y los de su tío, entre el rechazo de parte de la sociedad inglesa y el reclamo de su cultura de origen, así como aceptar su sexualidad en un contexto muy tradicional.

\section{a) Contexto}

La película transcurre a mediados de los años 80 en Reino Unido y fue estrenada en 1985. Unos años antes se había iniciado de manos de Margaret Thatcher un programa político neoliberal que tuvo como efecto un aumento drástico del desempleo (Anderson, 2001). Lo expresa el padre de Omar nada más empezar la película cuando habla a su hermano de su hijo: "Omar está en paro, como todo el mundo en Inglaterra". A principios de esa década tuvo lugar un cambio en la política de inmigración en Inglaterra, cuyas propuestas fueron reflejadas en el denominado White Paper. La ciudadanía británica fue dividida en tres: ciudadanos británicos, ciudadanos de territorios dependientes de Gran Bretaña y los ciudadanos británicos de los territorios de ultramar. Los inmigrantes podían solicitar la nacionalidad tras cinco años de residencia, principalmente. A mediados de la década, 
la población asiática y originaria del este de la India superaban los dos millones. La inmigración formaba parte tanto del debate público como político. De hecho, durante la campaña previa a las elecciones de 1987, los partidos políticos expresaban abiertamente que los controles a la población inmigrante debían ser justos y paralelamente se inicia un debate sobre la etnicidad de la población inmigrante (Abrahámová, 2007).

\section{b) Geografía y proyectos migratorios}

Se trata de una migración intercontinental de carácter familiar. La familia del protagonista procede de Pakistán. Durante las décadas de los años 50 y 60 hubo una gran oleada de pakistaníes hacia Reino Unido. El perfil más común era el de personas con bajos niveles de estudios y su procedencia era, generalmente, de zonas rurales. Se emplearon sobre todo en la industria textil y del automóvil. No se detecta ningún país de tránsito: se trata de una migración directa desde una antigua colonia, Pakistán, a Reino Unido. Así, pues, se trata de una migración por motivos económicos que esperaba encontrar la prosperidad en el sector industrial y comercial de Reino Unido.

En lo que se refiere a los proyectos migratorios, la relación con Reino Unido es ambivalente. La apreciamos a través de las figuras del padre y el tío de Omar. Los dos llegaron a Inglaterra con la meta de alcanzar un sueño. Pero el resultado ha sido muy desigual: el padre representa el fracaso del proyecto migratorio y el tío, aparentemente, el éxito. Nasser es un nuevo rico producto de las políticas puestas en marcha por el Thatcharismo: según él, ha sabido encontrar las ventajas que el sistema ofrece y posee distintos negocios, algunos gestionados sin escrúpulos. El padre, en cambio, está en paro, tiene problemas con el alcohol y se muestra muy crítico y decepcionado. La conversación entre los dos hermanos casi al final de la película ilustra muy bien esto que acabamos de describir:

- Nasser, tío de Omar: "En este maldito país que amamos y odiamos puedes conseguir todo lo que quieras, todo está a nuestra disposición. Por eso creo en Inglaterra. Tienes que saber cómo ganarle provecho al sistema...".

- Padre de Omar: "Este maldito país nos ha engañado, por eso estoy así. Debemos estar allí, en casa". 
- Nasser, tío de Omar: "Nuestro país ha sido sodomizado por la religión, al menos aquí podemos ganar dinero. Comparado con otros países, esto es un pequeño paraíso".

- Padre de Omar: ¿por qué estás tan triste?

- Nasser, tío de Omar: "Mi vida no tiene solución, solo me interesan mis negocios".

Son las dos posiciones entre las que se mueve Omar: de un lado, su padre, que se siente entre estafado y fracasado; de otro, su tío con sus ambiciones económicas pero que no se han traducido en un ambiente familiar feliz. Es decir, en ningún caso podemos hablar de un proyecto migratorio que haya satisfecho plenamente los impulsos y sueños iniciales. Algo que Omar no quiere reproducir.

\section{c) Perfiles y fase migratoria}

Omar pertenece a lo que denominan "segunda generación", aunque él nunca ha emigrado: ha nacido y se ha criado en Inglaterra. De hecho, a lo largo de la película observamos como a menudo varias personas pakistaníes le reprochan no conocer algunas pautas culturales o el haberse metido de lleno en la cultura inglesa: "Siempre la misma historia, la gente se integra allí donde esté", "no habla su propio idioma", etc. Omar es huérfano de madre y debe ocuparse de su padre enfermo de alcoholismo. Él se ocupa del sustento familiar y por este motivo deja los estudios inacabados: su principal motivación es ganar dinero.

Otros personajes relevantes en la película son el padre y tío de Omar, que hemos visto anteriormente; las primas de Omar, que también han nacido y crecido en Inglaterra y se enfrentan a ese juego de espejos entre el país de procedencia de su familia y la vida en Londres. Por último, cabe destacar a Johnny, el amigo y pareja de Omar, de nacionalidad inglesa.

Por tanto, teniendo en cuenta las fases del ciclo migratorio que vimos anteriormente, se trata de una familia con largo recorrido de vida en Inglaterra que incluye a descendientes que han nacido fuera de Pakistán. Salvo el padre de Omar. También se aprecia una estabilidad laboral en gran parte de la familia, así como residencial. No obstante, 
no esta estabilidad aparece como segregada, como veremos más adelante.

\section{d) La aculturación en la vida cotidiana}

\section{El espacio de vida de Omar y su familia}

Omar, el protagonista, reside en una casa muy humilde con su padre. De manera casi omnipresente tenemos siempre la vía del tren de cercanías que bordea la casa. El ruido es tan cercano que parece un sonido más de la casa. Nos hace pensar en la posibilidad de una discontinuidad urbana: un límite que separa un sector de la ciudad de otro. Esta discontinuidad la vemos también en las relaciones sociales de Omar: casi siempre con otras personas de origen pakistaní. Las reuniones familiares en caso del tío Nasser, donde nunca encontramos a ninguna persona que no sea de origen pakistaní. Incluso a la hora de encontrar trabajo Omar se dirige a sus familiares. En los negocios de su tío, de nuevo, encontramos prácticamente a personas de la misma procedencia.

La lavandería se vuelve el principal espacio en la vida de Omar, ya que él es el encargado y, además, desde el principio es el responsable de montar y adecuar el que será su nuevo lugar de trabajo. Son pocos los momentos de ocio mostrados y una de las escenas que refleja un momento lúdico de Omar es en casa de su tío, donde varios hombres pakistaníes están dentro de la habitación de Nasser en un ambiente ocioso fumando y bebiendo. Vemos una clara segmentación por género: los hombres reunidos en una parte de la casa y las mujeres, que apenas apreciamos, en otra.

En definitiva, gran parte de la vida de Omar transcurre en contacto con su familia: vive con su padre, frecuencia a la familia cercana e incluso su incorporación al mercado de trabajo transcurre con la familia u otras personas de origen pakistaní. Su mayor vínculo con los ingleses autóctonos será a partir de la relación de amistad, trabajo y amor con Johnny.

\section{El proceso de aculturación de Omar y otros miembros de la familia}

Es necesario distinguir entre la vida de Omar y sus primas, y las de sus progenitores. Omar vive atrapado, pero a la vez con bastante 
desenvoltura entre los mensajes que recibe cotidianamente de los dos países: en el que ha nacido y crecido, y el de origen de sus progenitores. Apenas presenta rasgos culturales del país de procedencia de su familia (por ejemplo, no conoce el idioma), pero el contacto con la sociedad inglesa tampoco es frecuente e incluso el rechazo se hace evidente. Varias escenas de su vida cotidiana lo ilustran. En un momento de la película un grupo de jóvenes le gritan: "Lárgate de nuevo a la selva, negro". Este menosprecio de parte de la sociedad inglesa lo expresa Omar también cuando se enfrenta a sus objetivos. Como una especie de revancha por lo vivido por su padre en un determinado momento de rabia nos dice "quiero mucho dinero, no voy a dejar que este país me oprima". Como si las nuevas generaciones no estuvieran dispuestas a vivir la situación de opresión vividas por sus padres y madres. Aunque predomina claramente el punto de vista o cómo lo viven las personas de origen inmigrante, la tensión latente con la sociedad inglesa mayoritaria también la percibimos a través de Johnny, a quienes sus amigos le recriminan su relación con Omar.

- Amigo: ¿Por qué trabajas para esa gente? Pakistaníes.

- Johnny: Es un trabajo. Quiero trabajar. Ya estoy harto de perder el tiempo.

- Amigo: Estoy enfadado. No me gusta ver a uno de los nuestros rebajándose a los pakistaníes. Sólo vinieron aquí para trabajar para nosotros. Por eso les trajimos, ¿de acuerdo? (silencio) Escúchame Johnny, no debes separarte de tu propia gente, porque nadie te querrá tanto como los tuyos. Cada uno tiene que estar en su ambiente.

En definitiva, como describe muy bien Cornut-Gentille d'Arcy (2016: 226) en su análisis del cine británico bajo el mandato de Thatcher, "Mi hermosa lavandería" no retrata a un conjunto de pakistaníes como representativos de su país, sino una gama de personas inmersas en un proceso de construcción de su identidad con sus contradicciones y sus tensiones. Por otra parte, casi podríamos decir lo mismo de la ciudadanía autóctona: Johnny estaría en un proceso similar de adaptación y reconocimiento de la diversidad de su país.

Pero Omar también recibe continuamente mensajes de advertencia por parte de los miembros de su familia u otros pakistaníes para no perder 
la identidad del grupo: "te has convertido en uno de esos blancos a los que llaman negros". El propio padre de Omar también se lo manifiesta: "Nos odian en Inglaterra y todo lo que haces es besar sus pies y presumir de que eres un muchacho inglés". Pero no solo Omar vive las tensiones de este proceso de aculturación en la sociedad inglesa, también su tío Nasser, que sí emigró desde su Pakistán natal y es un hombre de negocios de éxito. Lo vemos en una conversación con Johnny después de desahuciar a hombre de una habitación de su propiedad:

- Johnny: No está bien, ¿verdad? Los pakistaníes haciendo este tipo de cosas.

- Nasser: ¿Por qué no?

- Johnny: ¿Qué tendrían que decir sus enemigos sobre esto? No es exactamente integración, ¿verdad?

- Nasser: Pero yo soy un hombre de negocios, no un pakistaní profesional. A mí sólo me interesa la prosperidad de mis empresas

El tío Nasser no ha tenido, aparentemente, problemas a la hora de desarrollar su actividad profesional en el contexto de los años ochenta en Reino Unido.

- Nasser: Brindaremos por la señora Thatcher y por tu hermosa lavandería

- Jonnhy: ¿Se llevan bien?

- Nasser: Como el agua y el jabón.

Pero ese éxito no se ha extendido a otras esferas de su vida. La separación de su familia con la sociedad inglesa mayoritaria es muy visible. Varias personas de origen pakistaní lo manifiestan a lo largo de la película:

- - "Fíjate, que asco de vida. Son asquerosos e ignorantes. No son nada, pero insultan a la gente, a nuestra gente. Lo que esos cabrones necesitan es que les paguen con su propia moneda".

- - "Como alguien en su sano juicio puede decir que Europa es su lugar" 


\section{"Divinas", de Houda Benyamina (Francia, 2016).}

"Divinas" cuenta el día a día de Dounia, una joven con familia de origen magrebí y su amiga Maimouna, de padres que emigraron de Mali. Ambas viven en la periferia de Paris. Las dos sueñan con prosperar en la vida, partir de vacaciones, tener un buen coche, etc. Se sienten atraídas hacia otra joven, Rebecca, que vive de los trapicheos con droga en el barrio y exhibe poder económico y social. Pero al mismo tiempo conoce a un joven francés que hace que dude sobre el camino que le gustaría seguir. En definitiva, la película muestra el desasosiego de unas adolescentes y sus sueños en un entorno urbano que no les ofrece muchas oportunidades.

\section{a) Contexto}

Francia en el momento actual. Los jóvenes franceses con familias de origen magrebí siguen siendo percibidos como descendientes de la inmigración. Dicho de otro modo, como propiamente inmigrantes. Una percepción que se va reproduciendo por generaciones. Estamos en 2015, después de que el gobierno de Sarkozy haya efectuado gestos hacia un fortalecimiento del comunitarismo en Francia y una crisis económica que recorre Europa. La inmigración continúa en primera línea del debate político y social en Francia. Como en la película anterior, el contexto que se narra y el del momento de realización de la película coinciden.

\section{b) Geografía de las migraciones y proyectos migratorios}

Si ya en los ochenta el concepto de segunda generación empezó a extenderse para hacer alusión a los hijos de los magrebíes emigrados durante los treinta gloriosos, nuestros protagonistas encarnarían a los hijos de esta "segunda generación". Es el caso de Dounia, la principal protagonista. Ella no ha emigrado porque ha nacido y crecido en Francia. Incluso cabe pensar que su madre también nació en Francia. Dounia es hija de una madre soltera que ha nacido o crecido en Francia y que no ha conseguido encontrar la estabilidad. En ningún momento hacen referencia al país de origen. En el caso de Maimouna los 
antecedentes geográficos parecen estar más visibles en la figura del padre y la madre.

La madre de Dounia expresa el desencanto de la inadaptación y frustración. No tiene grandes expectativas para ella, pero sí quiere que al menos su hija profese y continúe con los estudios. No obstante, es la hija que la más ejerce de protectora de la madre.

ounia y Maimouna son adolescentes que sí tienen sueños, pero son también conscientes de que alcanzarlos no va a ser fácil. Hay dos escenas que ilustran sus ilusiones, pero también su miedo a la frustración. Sus sueños imaginando que se desplazan en un coche de alta gama por el barrio: los deseos que expresan contrastan con la realidad de bloques de pisos homogéneos grises. En otra escena, al principio, Dounia estalla contra su profesora:

- Profesora: Pero lo que no comprendas, mierda, es que intento ayudaros.

- Dounia: ¿Pero ayudarnos a qué, a ser los criados de esta sociedad?

\section{c) Perfiles y fase migratoria}

Las protagonistas son Dounia y su amiga Maiomouna. Como hemos dicho, las dos encarnan a esas jóvenes nacidas en Francia, pero a las que se les recuerda continuamente el origen inmigrante de sus familias. Las dos se mueven entre las inquietudes propias de la edad y las tradiciones religiosas de sus familias, particularmente Maimouna a la que sus padres siempre recuerdan que debe respetar la religión. El inicio de la película muestra muy claramente esta alternancia entre la vida en la periferia de la ciudad y los valores más tradicionales encarnados en la práctica religiosa.

Como personajes secundarios cabe destacar las familias de nuestras dos protagonistas: la madre de Dounia, como se han dicho, como un caso de exclusión que no ha podido reconstruir su vida en el país de destino de sus padres; y los padres de Maimouna, una familia más estructurada, de clase trabajadora y con una importante componente de religiosa. Estamos pues, con familias con una larga trayectoria de vida en Francia, pero en situaciones muy distintas. Dounia y Maimouna 
encarnan la descendencia, que comparten aspiraciones y problemáticas comunes, abrirse camino en los márgenes urbanos de París.

\section{d) La aculturación en la vida cotidiana}

\section{De Dounia y su amiga}

El espacio de vida: los márgenes urbanos de París, entre la vulnerabilidad y la exclusión

El espacio de vida Dounia y Maimouna es el barrio de París en el que residen. Casi toda la película transcurre entre esos bloques de pisos homogéneos y grises. Un paisaje homogéneo sin apenas zonas verdes, sin olvidar la zona de chabolas a la que llaman "el campamento gitano" y en la que reside nuestra protagonista. Dounia y Maimouna pasan sus días entre el hogar familiar, los parques y calles del barrio, la mezquita, el instituto, los centros comerciales, etc. Perciben el barrio como abandonado por el resto de la ciudad: "Aquí les importamos un cojón. ¡Mirad! ¿Qué coño es eso? Hace dos años que no tocan la obra”. En distintas escenas estos jóvenes parecen atrapados en una realidad urbana de la que es difícil escapar: zonas alambradas, bloques de pisos de varias plantas que parecen muros, etc. Una discontinuidad que provoca impotencia en nuestras jóvenes protagonistas:

- Dounia: "Sueño que estoy cayendo. Intento despertar. Pero no puedo. Sigo cayéndome. Cuanto más caigo, más me quemo. Y al final, ya no me duele, ya no me da miedo. Solo quiero estrellarme para que se acabe. Pero no se acaba nunca".

- Milouna: "Y yo qué, yo estoy siempre ahí para cogerte".

Sería una visión de París que resultaría desconocida para los estudiantes a los que se proyectase la película. Solo hay un momento en la película donde aparece una zona reconocible: el trayecto nocturno por los Campos Elíseos en el que tanto Dounia como Maimouna parecen querer expresar que ellas también son parisinas y por tanto pueden disfrutar igualmente del centro de la ciudad.

\section{De Dounia y Maimouna (y sus familias)}


Los protagonistas de esta historia ilustran un abanico muy amplio de los modelos de aculturación que distinguía Berry. La madre de Dounia presenta una situación de exclusión: de familia musulmana, se intuye que es madre soltera, apenas sobrevive en un local nocturno de música magrebí, ha perdido su casa y se ve obligada a vivir en una chabola. No mantiene vínculos familiares y casi todas las personas a su alrededor parecen tener características similares a ellas: los excluídos de Paris y de sus orígenes. Los excluidos de París. La familia de Maimouna representaría un modelo de segregación: no tanto porque la práctica musulmana está muy presente en sus vidas o siguen vistiendo como en sus países de origen, sino porque a lo largo de la película no mantienen relación con nadie que no sea procedente de su país. Además, se muestran especialmente sobreprotectores con la hija.

La situación de Dounia, nuestra joven protagonista, es la más compleja de definir. Su espacio de vida está muy circunscrito al barrio y a otros jóvenes que presentan características similares. La religión está cerca y a la vez lejana en la vida de estos jóvenes, pero no supone ningún motivo de controversia. Es más, Dounia la ve como un fraude porque se siente abandonada. Lo expresa cuando Maimouna le habla de una supuesta protección de Dios:

- Maimouna: (Mirando a la luna). Es Dios quien nos mira.

- Dounia: ¿No tiene otra cosa que hacer?

- Maimouna: Si Dios quiere. Podría hacérselo pagar a mi padre.

- Dounia: No te preocupes. Solo somos polvos para él en el cosmos. Microbios.

- Maimouna: Pero si eres Dios tienes responsabilidades. Estás obligado a velar por tus hijos. Es así. Está escrito.

- Dounia: Pues de momento no nos ha reconocido.

Apenas tienen contacto con otras personas fuera del barrio. Cabe subrayar además que cuando franquea su frontera, se sienten expulsadas por el resto de la ciudad. Hay una escena en la película en la que Dounia y Maimouna pasean por un centro comercial y un agente de seguridad no las deja pasar. Después de una trifulca les acaba diciendo: "Iros a divertiros a vuestro guetto". Pero la escena más brutal de la película que refleja esta barrera entre el barrio y el resto de la ciudad la encontramos al final, cuando en medio de una situación de 
impotencia y desgarro los jóvenes no consiguen convencer a unos bomberos para socorrer a una de las amigas (ahorramos decir el nombre para no revelar spoiler) bajo el pretexto de que la policía tiene que llegar para proceder al rescate.

No es de extrañar que estos jóvenes muestren sus recelos hacia la sociedad en general por sentirse excluidos y hacia la policía en particular por sentirse maltratados. Dounia también siente la necesidad de expresarles que no les tiene miedo.

Solo queda un resquicio para la integración, entendida como intercambio entre personas de origen diferente en situación de equilibrio: el inicio de una historia de amor entre Dounia y Djigui, el joven francés al que espía cuando lo observa o espía en sus clases de baile. Es la relación que hace dudar a Dounia sobre el camino que quiere seguir para prosperar: la opción más recurrente en el barrio a través de los trapicheos o buscar otra salida. ¿Cuál? No lo sabe, pero sí es consciente que en su caso no será fácil.

\section{Conclusiones}

Nuestro objetivo ha sido presentar un esquema de análisis que pueda servir de guía a estudiantes y profesores/as que quieran utilizan como soporte el cine de ficción para abordar distintas claves en los procesos migratorios. Para ello hemos seleccionado dos películas a modo de ilustración. Algunos de los conceptos que hemos introducido en nuestro debate aparecen bastante reflejados en las dos películas.

Las dos películas que hemos seleccionado tienen como protagonistas a jóvenes descendientes de la inmigración: ellos no han emigrado pero sus familias sí lo hicieron anteriormente y, a menudo, son percibidos también como inmigrados o, incluso, racionalizados. Los guionistas de las dos películas reúnen también este perfil. Ahora bien, las coordenadas de tiempo y lugar no coinciden: en un caso, se trata de un joven en el Reino Unido de los años ochenta del siglo pasado en pleno clamor social por las políticas puestas en marcha por el gobierno de Margaret Thatcher; en otro caso, una joven en Francia en la década actual, con una crisis económica y de identidad de la Unión Europea. Aun así, podemos detectar tanto elementos comunes como divergentes. 
Los dos jóvenes, Omar y Dounia, transcurren su día a día por un espacio de vida en los márgenes periféricos de la ciudad e interactuando, sobre todo, con personas vínculos migratorios. Los dos han abandonado repentinamente los estudios y sueñan con ganar dinero y alcanzar una vida mejor. Además lo manifiestan con cierto ajuste de cuentas con la sociedad en la que han crecido:

- Omar en "Mi hermosa lavandería": "Quiero ganar dinero. No voy a dejar que este país me oprima. Cuando estaba en el colegio, tú y tus amigos me pegaban. Ahora, ¿qué haces? Fregar suelos. Ponte a trabajar o estás despedido".

- Dounia en "Divinas": "Yo no quiero ser como tú, no quiero mendigar como tú. Yo tengo mi orgullo. Te juro por mi madre, te juro, que algún día yo ganaré más pasta de la que tú hayas soñado en tu puta vida. Incluso en tus sueños más profundos".

Tanto Dounia como Omar encuentran el amor en una persona del grupo mayoritario: un inglés y un francés. Un paréntesis en su espacio de vida y reto a la vez, sobre todo para Omar al tratarse de una relación homosexual. Pero en ambos casos los inicios de la relación parecen no encontrar barreras. Aunque posteriormente no conocemos su desarrollo, cabe preguntarse que, de existir, dichas barreras se construyan desde fuera.

Pero también encontramos parámetros distintos en su proceso de aculturación. La llamada a la "cultura de origen" está más presente en la vida de Omar, tal y como quiere reflejar su guionista. Son bastantes los guiños e incluso reproches que recibe Omar: no conoces el idioma, frecuenta mucho a los ingleses, te consideras inglés y no lo eres, etc. En el caso de Dounia es menos evidente, pero tampoco está ausente. Por ejemplo, cuando se le recuerda que sería conveniente frecuentar de nuevo la mezquita. No podemos olvidar tampoco que Omar, al ser un hombre, encuentra más fácilmente su salida en los negocios familiares. Pero Dounia, que se introduce en unos negocios muy masculinizados sufre una mayor vulnerabilidad.

En definitiva, Omar vive una segregación de la que participa tanto la población inglesa como la de origen pakistaní. Como una especie de pacto con cierto equilibrio, pero no exento de tensiones. El mayor desafío de Omar va a ser vivir su homosexualidad en un contexto 
familiar muy conservador. Dounia está al borde de una exclusión en la que su propia madre ya ha emergido. Las barreras con el resto de ciudad parecen más infranqueables. Parece más cercada. El mayor reto de Dounia será romper dichos muros siendo una chica joven sin apoyo familiar.

Con el análisis de las dos películas hemos querido mostrar como el cine puede ser un instrumento para los estudiantes de Antropología, Geografía u otras disciplinas para reflexionar sobre determinados conceptos y problemáticas. Particularmente cuando se trata de obras creadas por personas con vínculos migratorios como es el caso de "Mi hermosa lavandería" y de "Divinas". Consideramos que se trata de un adecuado soporte para la reflexión y la creatividad de los estudiantes.

\section{Bibliografía}

Abrahámová, N. (2008). Immigration Policy in Britain since 1962. Trabajo de fin de máster, Masaryk University, Faculty of Arts. Disponible en: https://is.muni.cz/th/pbnrq/.

Alonso Seoane, M.J. (2012). Imaginarios sociales del cine español de migraciones. Imagonautas, 1(2), 41-61.

Anderson, P. (2001). Historia y lecciones del neoliberalismo. En F. Hourtart y F. Polet (Coor.), El otro Davos: globalización de resistencias y de luchas (pp. 13-30). Madrid, España: Plaza y Valdés.

Barfield, T. (2001). Diccionario de Antropología. Barcelona: Bellaterra.

Bastenier, A, y Dassetto, F. (1995). L'Integratio des immigres en Europe: un cadre conceptuel. En H. Gerard y V. Piche (Eds.), La Sociologie des Populations, pp. 417-430. Montreal : Les Presses de l'Université de Montreal.

Berry, J. W. (2003). Conceptual approaches to acculturation. En K.M. Chun, P.B. Organista y G. Marin (Eds.), Accultura-tion: advances in theory, measurement and applied reserch, pp. 1738. Washington DC : American Psychological Association. 
Courgeau, D. (1980). Analyse quantitative des migrations humaines. Paris: Masson

Cornut-Gentille d'Arcy (2006). El cine británico en la era de Thatcher. ¿Cine Nacional o Nacionalista? Zaragoza: Prensas Universitarias de Zaragoza.

Courgeau, D. (1980). Analyse quantitative des migrations humaines. Paris, Francia: Masson.

Eychenne, A. (2017). Les castes s'exportent au Royaume-Uni.

Manière de voir : L'engranage identitatire. Ethnicité, Minorités, Diversité, 152, 40-42.

Galiano León, M. (2008). Movimientos migratorios y cine. Haol, 15, 171-183.

López-Campos Bodineau, C. (2012). L’immigration dans le cinéma français et le québecois à travers quelques films. Hommes et Migrations, 1297, 20-28.

Maroto Blanco, J.M. y López Ortega, María Teresa (2018). La figura del negro a través de la gran pantalla. La entrada de España en la Unión Europea como punto de inflexión. Historia y comunicación social, 23(2), 567-583

Moyano, E. (2016). La piel quemada. Cine y emigración. Madrid: Ediciones La Torre.

Noiriel, G. (2017). Le mythe d'une France accueillante. Manière de voir : L’engranage identitatire. Ethnicité, Minorités, Diversité, $152,64-67$.

Rea, A. y Tripier, M. (2009). Sociología de la inmigración. Barcelona, España: Hacer Editorial.

Saeed, A. (2007). Media, racism and islamophobia: the representation of Islan and Muslims in the media. Sociology Compass, 1(2) 443-462.

Santaolalla, I. (2005). Los "Otros". Etnicidad y "raza" en el cine español contemporáneo. Zaragoza: Prensas Universitarias de Zaragoza. 
Tur, B. (2009). Españolas en París ou la solitude des bonnes à tout faire espagnoles à Paris. Décadrages, 14, 66-78.

Türkmen, C. (2009). L'évolution de la représentation des migrants au cinéma et dans les séries télévisuelles. Hommes et Migrations, 1277, 104-106.

Yahi, N. (2007). L'immigré dans la fiction, des années soixante à nos jours. En B. Stora y E. Temime (Dir.), Immigrances. L'immigration en France au XX siècle (pp. 275-298). París, Francia: Hachette Litteratures.

Vallejo Peña, A. (2014). Inmigración e integración social desde una perspectiva cinematográfica. Revista de Estudios Fronterizos del Estrecho de Gibraltar, 1. 


\title{
Entretenimiento y el espectáculo como discursos televisivos
}

\author{
Xavier Brito Alvarado \\ Universidad Técnica de Ambato, Ecuador \\ Nelly Guamán Guadalima \\ Universidad Técnica de Ambato, Ecuador
}

\section{Resumen}

El presente trabajo muestra una reflexión sobre el discurso que se da en la televisión a través del entretenimiento y el espectáculo. Determinando a la televisión como la pantalla que muestra una realidad, crea sentidos y simbolismos de pertenencia social.

No cabe duda que cualquiera que sea la mirada teórica sobre la televisión, ésta seguirá constituyéndose como uno de los medios masivos más penetrantes en la región.

Este capítulo parte de una revisión bibliográfica sobre la televisión y se enfoca en pensar al espectáculo y al entretenimiento televisivo como discursos imperantes en la producción televisiva, que han sido pensados desde una mirada reduccionista de superficialidad y menosprecio, dejando de lado las miradas críticas que permiten pensarla como un escenario de convivencia social.

Palabras clave: Entretenimiento, televisión, espectáculo, discurso. 


\section{Introducción}

Todos hablamos de televisión

sin saber exactamente

de lo que estamos hablando.

Arlindo Machado (2000).

$\mathrm{V}$

IVIMOS una sociedad de la pantalla en el sentido de que éstas han colonizado la percepción de la vida, y una de las pantallas más importantes es la televisión. El éxito de su empoderamiento en la cotidianidad se debe, gracias, a su amplio abanico de producciones destinadas, en su mayoría, a ofrecer educación, entretenimiento y espectáculo para todos los gustos, democratizando su uso; además de ser muy sencillo su uso, por esto su debate no debe agotarse en sus contenidos, sino que debe ser ubicado dentro de los gustos, emociones y sensibilidades de la población.

De esta manera, la televisión "ha pasado a formar parte de diversas normas de la vida pública [...] su cotidianidad ha trascendido lo doméstico y la televisión en ese intrincado mundo de relaciones y ritualidades complejas son un aporte fundamental para comprender el lugar que ocupa en nuestra sociedad" (Grimson, 1999, pp. 197,198).

Sobre la televisión existe una amplia literatura, mayoritariamente, enfocada en los efectos que produce en la sociedad. En Latinoamérica gran parte de esta literatura ha tenido diversas miradas, así tenemos la funcionalista y su vertiente tecnológica, otra mirada ha sido la crítica ideológica de enajenación, muy anclada en los postulados de la Escuela de Frankfurt, de manera especial, Theodor Adorno y Max Horkheimer. Estas dos posturas, si bien tienen fundamento teórico y metodológico, no pueden ser consideradas como últimas y determinantes al momento/a la hora de pensar a la televisión

Sin embargo, desde los años sesenta y ochenta, surgieron nuevas miradas comunicacionales sobre la televisión; miradas más locales y cercanas al contexto latinoamericano. Jesús Martín-Barbero (2002, 2003), Luis Ramiro Beltrán (1997), Eliseo Verón (1987, 1995, 204), 
entre otros, iniciaron el camino para pensar de manera distinta a la televisión no solo como un artilugio tecnológico o como un aparato de dominación ideológica, sino como un espacio de reconocimiento cultural. Entre otros pensadores latinoamericanos tenemos:

Desde la literatura Beatriz Sarlo (1994); el consumo cultural y la antropología Néstor García Canclini (2012); de lo popular Carlos Monsiváis (1993); el consumo y la recepción Guillermo Orozco (2001), por citar algunos ejemplos, han aportado una crítica para entender a la televisión y sus sensibilidades, permitiendo construir una mirada fértil para entenderla como un "espejo" de las sociedades latinoamericanas, gracias a que crean sentidos y simbolismos de pertenencia social.

Así, el individuo se muestra o cumple la función de espectador que siente y se ve reflejado en los contenidos que la televisión muestra, a través de las realidades a las que está acostumbrado a ver, y que, a pesar de no existir una relación directa, el telespectador siempre se sentirá familiarizado con los contenidos que vea, ya que éste decidirá qué pondrá en las pantallas. Este medio no deja espacio a la reflexión de los individuos por sus limitadas informaciones que ha decidido colocar para que sean parte del debate público.

Sobre la televisión

La tele es el gran interlocutor a quien se le cede el centro del diálogo familiar.

Carlos Monsiváis.

La importancia social de la televisión radica en que "[...] es el medio central de la comunicación, ya que alrededor de esta máquina semiótica se organiza los otros medios, la política, la gobernabilidad, el saber social" (Rincón, 2006: 170). La televisión se ha convertido en un valor de época que atraviesa las formas de pensar y accionar de los sujetos televidentes.

Carlos Monsiváis argumenta que "la televisión es el gozo incontaminado que libra a la familia de los peligros de la calle; para otros que se confinan en la murmuración es el asedio de la inmoralidad para la que no hay respuesta; la mayoría la asume con gratuidad distraída" (1993: 21). 
Los análisis sobre el contexto social de la televisión se pueden bosquejar en: Williams (1979), Martín-Barbero y Muñoz (1992), Vilches (1993), Silvertstone (1996), Bourdieu (1997), González Requena (1999), Rey (1999), Abruzzese y Miconi (2002), Orozco (2002), Rincón (2002), (2006), entre otros.

Miradas críticas como las de Pierre Bourdieu sobre que "la televisión incita a la dramatización, en un doble sentido: escenifica, en imágenes, un acontecimiento y exagera su importancia, su gravedad, así como su carácter dramático y trágico" (1997: 23). O como la que expone Theodor Adorno que la televisión distorsiona la realidad al crear una mirada "mosaico y granulosa" del mundo.

Adorno dispara un ataque implacable a la televisión sin conocer de hecho a la televisión, sin realizar una investigación extensiva del conjunto de propuestas que la televisión estaba presentando en aquel momento. No hay nada de raro, pues si aún en el 2000 existen intelectuales que no ven a la televisión, eso debió ser norma en 1954, más aún en los círculos severísimos de la Escuela de Frankfurt (Machado, 2000: 63).

Frente a estas posturas Jesús Martín Barbero describe a la televisión como un espacio para conectar y contar a la sociedad.

La televisión ocupa un lugar estratégico en la cultura cotidiana de las mayorías, en la transformación de las sensibilidades, en los modos de percibir el espacio y el tiempo y de construir imaginarios e identidades (...) y que en lo que concierne a la televisión, la cuestión sigue siendo explicar para transformar, y no quedarse en la satisfacción que procura su negación informada (1996: 38).

La televisión en las sociedades latinoamericanas tiene un lugar privilegiado, ocupa un espacio central en los hogares, es la compañera cotidiana, sus cuentos nos divierten y entretienen para visibilizar y entender al mundo de una manera seductora. Está seducción televisiva comunica narrativas populares cercanas al pueblo, conjugando la oralidad y la imagen. "[...] es un instrumento que, teóricamente, ofrece la posibilidad de llegar a todo el mundo [...] (Bourdieu, 1997:18). 
La cotidianidad es el mejor teatro desde donde la televisión argumenta sus discursos, la sociedad se entretiene, se mira y se entera de los hechos desde ella. Sin duda, no fue el primer medio de comunicación global, pero ayudó a conjugar la idea de Marshall McLuhan sobre la "Aldea Global".

Para contar la cotidianidad, la televisión posee una serie de formatos que permite no solo narrar, sino que para tener cercanía con la gente crea un pacto de comunicabilidad entre los productores y el público que ha trasformado las formas de contar las historias.

1. Respecto a la realidad: (géneros) ficción y documental

2. En relación a las audiencias: (géneros) infantil, juvenil, femenino, adulto y familiar

3. En relación con los contenidos: (géneros) ecológico, político, educativo, cultural $[\ldots]$

4. En relación con la intencionalidad: (géneros) educativo, cultural, recreativo, informativo

5. En relación con los formatos: (género) telenovela, talk show, concurso (Rincón, 2006:182).

Por tanto, la televisión en su conjunto es una actividad domesticada. Thomas Tufte considera a la televisión como un medio esencialmente doméstico y debe entender dentro del contexto de la casa y familia, como de las realidades sociales, políticas y económicas. "[...] La televisión como inherente a una cultura técnica y de consumo que es tanto local como nacional e internacional, una cultura que es al mismo tiempo tanto privada como pública" (Tufte, 1997, pp.70-71).

Gérard Imbert argumenta que el mundo atraviesa una profunda transformación social, donde la producción simbólica de las imágenes ha invadido la cotidianidad hasta un punto de saturación y "la televisión es sin duda el medio que más fomenta el voyueurismo, en un gozar de lo visible sin más mediación que el ojo voyeurista de la cámara, que hace aquí las veces de ojo de la cerradura" (Imbert, 2003, pp. 108-109). La televisión posee un elevado nivel de creación de ilusiones y significados para la dramaturgia cotidiana, en este sentido, Gilles Lipovetsky alega que: 
La telepantalla que ocasiona una ruptura profunda con el cine en la medida en que la recepción de las imágenes se hace a domicilio. Mientras que el cine se constituye a partir de un lugar colectivo y público (la sala oscura), la televisión ofrece un espectáculo de imágenes en la propia casa. Se presenta como un cine a domicilio (2009: 218).

Dominique Wolton (2009: 13) describe a la televisión como uno de los símbolos más visibles de las sociedades democráticas, por ello la población deposita en ella muchas esperanzas de paz, sociabilidad y conocimiento, sin embargo, no ha sido capaz de satisfacer todas estas demandas. No cabe duda, la televisión crea una esfera de referencialidad para la comunicación que se constituye como el referente más importante para contar a la sociedad.

La televisión ha triunfado como medio más popular y como narrador de nuestras vidas porque ha sabido responder a la temporalidad hogareña, ha promovido relaciones afectivas con sus audiencias e identificaciones en sus públicos, se ha adaptado al tomo de la conversación diaria, sirve de compañía en los quehaceres cotidianos, no exige mucho al televidente y le promete mucho; entretenimiento permanente (Rincón, 2006: 22).

La televisión es la mejor máquina para contar historias, cada sociedad reproduce a través de ella sus maneras de interpretar al mundo de una forma entretenida y dramática. "La televisión es, en nuestra cultura, el modo más común de enterarse las cosas. Por tal razón-y esto es lo decisivo-su forma de presentarnos el mundo se convierte en el modelo que ha de seguir el mundo para presentarse" (Abruzzese, Miconi, 2002: 129). En este sentido, la televisión no solo constituye un espacio para construir discursos, sino modos diversos de relaciones y modos de crear realidades, simulaciones y simulacros.

Como describe Rincón (2006: 165), la televisión es una máquina narrativa destinada para educar, informarse y entretenerse. Para Abruzzese y Miconi, "la televisión continúa siendo nuestra realidad y continúa contando y contentándonos, entreteniéndonos con los hechos y deseos (2002: 16). De esta manera, la televisión se convierte en el espacio para visibilizar los rituales y experiencias del mundo. 


\section{Sobre el entretenimiento}

El entretenimiento funciona como la gran promesa mediática de "llevarnos fuera de nuestros problemas diarios de escapar de la miseria de la vida" (Gaber, 2000: 6). El entretenimiento al constituirse en una forma de vida se ha convertido en un objetivo en sí mismo que transita de la pantalla hasta nuestra cotidianidad, construyendo una representación de la vida mismo.

La cultura del entretenimiento suele confundirse con la denominada filosofía light debido a la búsqueda de placeres veloces y efímeros. El entretenimiento se ha convertido en una base fundamental para las estéticas de las Industrias Culturales encuadradas en la denominada cultura mainstream entendida como:

Dominante o gran público, y se emplea generalmente para un medio, un programa de televisión o un producto cultural destinado a una gran audiencia. El mainstream es lo contrario de la contracultura, de la subcultura de los nichos de mercado, para muchos, es lo contrario del arte (Martel, 2012: 22).

Históricamente el entretenimiento puede rastrearse en el teórico literario ruso Mijail Bajtin y el punto de partida de la Edad Media y el Renacimiento, que es asumido como un mecanismo social donde la risa y la fiesta se oponían a una cultura burguesa oficial. La risa, la fiesta eran exposiciones públicas de rebeldía, una reivindicación del sentido carnavalesco, una especie de cultura cómica que puede dividirse en:

1. Formas y rituales del espectáculo (festejos carnavalescos, obras cómicas representadas en las plazas públicas, etc.)

2. Obras cómicas verbales (incluso las parodias) de diversa naturaleza: orales y escritas, en latín o en lengua vulgar.

3. Diversas formas y tipos del vocabulario familiar y grosero (insultos, juramentos, lemas populares, etc.) (Bajtin, 2003: 7).

Para Martín-Barbero "la Edad Media profunda es aquella en lo que popular se constituye a un tiempo desde el conflicto y desde el diálogo" (2003: 85). En este momento aparece la plaza pública como un lugar de reivindicación social, considerada como "[...] el espacio no segmentado, abierto a la cotidianidad y al teatro, pero un teatro sin 
distinción de actores y espectadores. A la plaza se la caracteriza sobre todo un lenguaje; mejor la plaza es un lenguaje, un tipo particular de comunicación" (Bajtin, 2003: 142).

En la plaza el carnaval alcanza su plenitud, la cultura popular se impone a la cultura oficial, la utilización de las máscaras representa los símbolos de irreverencia al poder conjugando un doble sentido; primero el ocultamiento de la identidad y en segundo la simulación para el engaño a la autoridad. "La máscara está en la misma línea de operación que los sobrenombres y los apodos: ocultación, violación, ridiculización de la identidad, y al mismo tiempo realiza el movimiento de las metamorfosis y las reencarnaciones, que es el movimiento de la vida (Martín-Babero, 2003: 89).

El entretenimiento es una de los pilares mercantiles y narrativos de las industrias culturales, conllevando a que los productos mediáticos se conviertan en "una cultura que marca hoy todo con un rasgo de semejanza. Cine, radio y revistas constituyen un sistema. Cada sector está armonizado en sí mismo y todos entre ellos" (Adorno, 1998: 165). De esta manera, el entretenimiento ha convertido a las obras mediáticas en objetos mercantiles, que forman parte del sistema de producción capitalista.

\section{E1 discurso del espectáculo}

Walter Benjamin describe al espectáculo como un sentido en que "la humanidad se ha convertido ahora en espectáculo de sí misma. Su autoalienación ha alcanzado un grado que le permite vivir su propia destrucción como un goce estético" (Benjamin, 2012: 33).

Benjamin presenta una crítica a la sociedad industrial, donde el arte ha sido desplazado por una industrialización de las obras artísticas, en que la estética ha perdido el aura de originalidad, abriendo el camino conceptual para un sinnúmero de publicaciones sobre el espectáculo y entretenimiento.

No obstante, uno de los trabajos que ha delineado el debate sobre el espectáculo ha sido el expuesto por Guy Debord en "La sociedad del espectáculo" (1967) que pone de manifiesto, desde una mirada situacionista, algunas cuestiones como la espectacularización de la vida. "La vida entera de las sociedades en las cuales reinan las condiciones 
modernas de producción se presenta como una inmensa acumulación de espectáculos" (Debord, 1993: 3).

Otro pensador que aborda al espectáculo es Lipovetsky (2006) que define a nuestro tiempo por la presencia de un nuevo sujeto marcado por el hedonismo y el narcisismo. Alessandro Baricco (2008) hace una alusión al espectáculo contemporáneo como el declive de la cultura occidental a favor de una cultura de la rapidez, de la frivolidad, una cultura sin estética y valores.

Mario Vargas Llosa también aporta su crítica al espectáculo al definir la situación actual como "[...] la de un mundo donde el primer lugar en la tabla de valores vigente lo ocupa el entrenamiento, y donde divertirse, escapar del aburrimiento, es la pasión universal" (2012: 33).

Para Rincón (2006, pp. 42,43) la televisión se ha convertido en una máquina narrativa de espectáculos destinados a la seducción y goces por mostrar una dimensión lúdica de la vida, en este sentido, promete "un mundo feliz" lleno de goces, diversión, felicidad para todos.

La televisión y en general los medios de comunicación transforman el entretenimiento en espectáculo; la economía, política y la cotidianidad han comenzado a ser regidas por el espectáculo desembocando es un show permanente de la cotidianidad.

El mundo del show y su emocionalidad actuada se ha multiplicado y ha llegado a donde jamás se creyó: la política, la religión, la educación, la literatura, el crimen. La vida se ha convertido en una actuación, una performance, un acto que se realiza para satisfacer a los otros como si fuera una audiencia televisiva [...] El espectáculo produce una conciencia que apunta a la celebridad, a la belleza, a la fama, reevalúa cualquier reacción de shock [...] el resultado, una ironía: todos creemos que somos protagonistas porque somos espectadores (Rincón 2006, pp.7,58).

Benjamin asume al espectáculo como una crítica a la sociedad industrial en que el arte ha sido desplazado por una industrialización de las obras artísticas. El espectáculo como categoría de análisis comunicacional parte del verbo latino "spectare" y del dominativo "spectaculum" el primero hace evocación a mirar y el segundo aquello que se ofrece a la visión. 
El espectáculo consiste en la puesta en relación de dos factores: una determinada actividad que se ofrece y un determinado sujeto que la contemplen. Nace así el espectáculo, de la dialéctica de estos dos elementos que se materializan en la forma de una relación espectacular (Gonzalez Requena 1992: 55).

El espectáculo se descubre como una elaboración de la seducción, un ejercicio nacido desde el poder que recae en el deseo de mirar a lo otro "esta es la causa de que todo poder deba, necesariamente, espectacularizarse, pues sólo pervive y se asiente el poder capaz de hacerse desear" (Gonzalez Requena, 1992: 60). En este sentido, Guy Debord aseveraba que el espectáculo es una creación del poder.

En la raíz del espectáculo se halla la más vieja especialización social, la especialización del poder: El espectáculo es entonces una actividad especializada, que habla en nombre de todas las demás, Es la representación diplomática de la sociedad jerárquica ante sí misma, donde toda otra palabra está excluida. Lo más moderno es también lo más arcaico (Debord, 2008:37).

Por ello las sociedades contemporáneas son dirigidas no tanto por las relaciones de producción, sino por las relaciones de seducción como lo ha anunciado Lipovetsky (2006). Para Debord el espectáculo comprende una serie de dinámicas comunicacionales creando un mundo de imágenes seductores de la vida, acumulándose como discursos reiterativos que se apropia de los sentidos.

Las imágenes desprendidas de cada aspecto de la vida se fusionan en un cauce común, donde la unidad de esta vida es irrecuperable. La realidad vista parcialmente se despliega dentro de su propia unidad general como pseudomundo aparte, objeto de mera contemplación. La especialización de las imágenes del mundo halla su culminación en el mundo de la imagen autónoma donde el mentiroso se miente a sí mismo. El espectáculo es en general, como inversión concreta de la vida, el movimiento autónomo de lo no viviente (Debord, 2008: 32). 
La espectacularización funciona bajo lógicas y modelos de comunicación unilateral y unidireccional, una especie de mercadería de intercambios simbólicos, el espectáculo sobredimensiona el hecho social mercantilizándolo para obtener un rédito económico.

El espectáculo en la sociedad corresponde a una fabricación concreta de la alienación. La expansión económica se da principalmente a través de la expansión de esa producción industrial específica. Lo crece con la economía que se mueve por sí misma no puede ser sino la alienación que precisamente se hallaba en su núcleo original (Debord, 2008: 41).

El espectáculo y la espectacularidad han permitido que la realidad se convierta en una especie de bien público, donde la confusión entre el sujeto que mira y el objeto que se observa desencadene en una falsa representación de la realidad. "La representación ya no es portadora por un sujeto único, sino que flota, se diluye, es ubicua es derecho de todos y territorio de nadie: la imagen deviene imaginería, colección de imágenes repetitivas, que cada uno consume” (Imbert, 2003: 107).

El espectáculo desarrolla mecanismos de ideologización "en el sentido de Mannheim, despotismo del fragmento que se impone como seudosaber de un todo fijado, visión totalitaria se realiza desde ahora en el espectáculo inmovilizado de la no-historia. Su realización es también su disolución en el conjunto de la sociedad" (Debord, 2008, pág. 67), la espectacularización construye una imagen, una visión del mundo que enuncia una fantasía que llega como mensaje a la audiencia.

Según Vargas Llosa el espectáculo tiene una mirada económica marcada por la idea de la cultura como algo autónomo lleno de valores estéticos, éticos e ideas, donde las obras de artistas interactúan con el resto de la vida social. La conceptualización de Vargas Llosa sobre el espectáculo gira en torno a las ideas de ocio y vaciedad de la sociedad.

La de un mundo donde el primer lugar en la tabla de valores vigente lo ocupa el entretenimiento, y donde divertirse, escapar del aburrimiento, es la pasión universal [...] Pero convertir esa natural propensión a pasarlo bien en un valor supremo tiene consecuencias inesperadas: la banalización de la frivolidad y, en el campo de la información, que prolifere el periodismo irresponsable de la chismografía y el escándalo (Vargas Llosa, 2012, pp. 33-34). 
Arlindo Machado, a diferencia de Vargas Llosa, argumenta que el espectáculo se acerca a una mirada platónica encuadrada en el simulacro, el mundo contemporáneo es una civilización de imágenes que sería un sinónimo de la sociedad del espectáculo. Para Machado la palabra espectáculo constituye un argumento para designar un mundo donde se centraliza a la imagen sobre los argumentos.

El espectáculo, tal como lo entiende Debord, tiene más afinidades con el simulacro platónico que con la mercancía marxista, resultando por lo tanto un concepto pre-capitalista. Parece que toda la tragedia del mundo contemporáneo, en el argumento de Debord, residiera en el hecho de que las cosas se volvieran imágenes, lo que me parece una forma de escamotear el verdadero origen de los problemas y de transformar las dificultades reales en un parloteo filosófico (Machado, 2000, pp. 8-9).

Para Paula Sibilia el espectáculo nace como una manera de ver el mundo por medio de las imágenes destinadas a satisfacer el triunfo de un modo de vida basado en el disfrute.

Otra mirada crítica es la de Alessandro Baricco quién argumenta que la humanidad está atravesada por el discurso de un fatalismo cultural: "Todo el mundo percibe, en el ambiente, un incomprensible apocalipsis inminente; y por todas partes, esta voz que corre: los bárbaros están llegando, estamos siendo saqueados por depredadores sin cultura y sin historia" (Baricco, 2008: 12). Para este autor vivimos una especie de mutación cultural que se sustenta en la espectacularidad y velocidad, matizado por efectos especiales (música, guiones, montajes, entre otros).

Si tuviere que resumirle, diría lo siguiente: todo el mundo percibe, en el ambiente, un incomprensible apocalipsis inminente; $y$, por todas partes, esta voz que corre: los bárbaros están llegando. Veo mentes refinadas escrutar la llegada de la invasión con los ojos clavados en el horizonte de la televisión (Baricco, 2008: 12).

El espectáculo se ha convertido en la narrativa mediática más importante enfocado en los dramas y conflictos comunes, "así, el espectáculo no es un mal contemporáneo, sino un modo de ser sujeto llamado humano y de los colectivos sociales en busca de pasar lo mejor posible la vida cotidiana" (Rincón, 2006: 62). 
El espectáculo tiende a crear una representación de la realidad, de ahí que "la representación ya no es portadora por un sujeto único, sino que flota, se diluye, es ubicua es derecho de todos y territorio de nadie: la imagen deviene imaginería, colección de imágenes repetitivas, que cada uno consume" (Imbert, 2003:107).

\section{Sobre las audiencias}

Los contenidos mediáticos, en especial desde la televisión, han hecho que la opinión pública se vaya alienando a un pensamiento consumista, hoy las audiencias que están frente a las pantallas siguen siendo receptoras de información; éstas no debaten, no indagan, no desarticulan los mensajes y las informaciones que la televisión y demás medios de comunicación les ponen en frente a través de la publicidad.

Los encuentros personales se vuelven contactos virtuales, en todo caso experiencias vicarias, y la participación de las audiencias que se posibilita, salvo excepciones, se traduce en exclamaciones y zappings bajo techo, mientras que la inconmensurable representación mediática sigue teniendo un crecimiento vertiginoso y se constituye en producto y proceso a la vez, y en el vehículo para conocer, aprender, sentir y gustar (Orozco, 2001:157).

Quizá uno de los problemas sobre las audiencias pasivas sea el tipo de información que se genera, además el interés de las audiencias versa en el consumo de lo que consideran interesante o que se ajusta a sus necesidades de entretenimiento y de espectáculo, que son utilizados como recursos de la publicidad para hacer más "atractivo" un producto o un servicio y llevarlo a las pantallas para lograr que este sea consumido.

El espectáculo y el entretenimiento han pasado a ser parte de la vida light del ser humano, son considerados dentro de la esencia del individuo, pues los individuos no están extasiados por obtener información; estos comportamientos son algunas de las causas que han demostrado la pasividad con las que se han mostrado las audiencias.

Ante estos problemas que se han ido generando, se puede considerar que gran parte de la responsabilidad también la tienen los avances tecnológicos que han hecho que las audiencias tengan la información a la carta y al día, es por ello que un individuo no se preocupa por salir a buscar información, sino que solo acude a los medios tradicionales y 
digitales para enterarse del acontecer de la sociedad. "Hoy no importan los valores, la inteligencia, los saberes; se nos juzga, por cuán entretenidos somos" (Rincón, 2003: 70), pues Rincón (2003) considera a la televisión como la "máquina de producción de mensajes", esa producción que llega directamente a las audiencias, como bien se mencionó en párrafos anteriores, esa producción que invade el cerebro y le lleva a producir diferentes acepciones sobre lo que se ve y se escucha.

Los mensajes que se emiten, cada vez están más pensados para que las audiencias solo consuman, como bien se mencionó, son audiencias que solo buscan que la información que reciben les cause placer, por ende la información que se les coloca en frente para su consumo, es aquella que entretiene, es aquella que causa satisfacción, que no obliga a los individuos a pensar ni reflexionar sobre el contenido, sobre la esencia del mensaje.

Lo referido en el párrafo anterior, se contrasta con lo que Vargas Llosa menciona sobre que el espectáculo gira en torno a las ideas de ocio y vaciedad de la sociedad; es decir un desinterés muy arraigado por lo que no parece "interesante", por lo que obliga o lleva a la reflexión. Se puede afirmar que nos encontramos dentro de una sociedad que vive una vida light que solo está interesada en consumir y consumir; es por eso que la telenovela de las 10 de la noche, o la serie del amor imposible, venden más que un reportaje o un aporte desde la ciencia.

Estamos viviendo en una sociedad light y que así como hoy la Coca Cola no tiene azúcar, el café es descafeinado, la cerveza no tiene alcohol y todo es fat free, la sociedad carece de sustancia, de pensamiento y ha perdido sus valores esenciales (La Nación, 2001).

De todos esos hombres y mujeres light, está conformada la sociedad de la "nueva era", en donde sus individuos están presentes, sí, pero presentes físicamente porque en mucho de los casos, el pensamiento queda en segundo plano, pues el hombre light es inmediatista, se conforma con ser feliz sin poner a duda ningún aspecto en su vida.

Para entender por qué la televisión se ha convertido en ese inmenso cajón de sastre en el que "todo vale, si es por la audiencia", es imprescindible tener en cuenta el contexto global en el que se desarrolla 
esta actividad. Sólo teniendo presente dicho contexto (García Reina, 2004).

De estas sociedades, también se deben preocupar los medios de comunicación, pues así como se tienen que adaptar los programas de televisión, las novelas; también se debe estar pendiente de las audiencias tan cambiantes, que un día quieren algo y al otro día ya tienen otras preferencias; sin duda alguna, es necesario realizar un replanteamiento del accionar de los medios de comunicación y de que estrategias se están trabajando y se tienen que adoptar para entretener y crear pertenencia en las audiencias.

\section{El fenómeno televisivo y la migración}

La percepción de los asuntos sociales ha estado condicionada en gran parte por la contribución de los medios de comunicación, así se lo ha especificado en la teoría de la Agenda Setting, dado a que los medios han puesto énfasis en ciertos temas y la migración ha sido uno de estos temas.

La migración ha sido el foco de atención para las sociedades, creando diferentes debates a su alrededor. Las imágenes capturadas por los medios de comunicación han causado diversas miradas al tema de la migración.

La migración mantiene un vínculo estrecho con los medios de comunicación, así lo demuestran los estudios sobre esta temática, entre los más relevantes tenemos "la integración de las poblaciones migrantes, la desterritorialización de las culturas (García Canclini, 2009) y el mantenimiento de su identidad cultural y vinculación con los territorios de origen (Cornejo, Bellón \& Sánchez, 2008; King \& Wood, 2001; Meyer, 2005)" (Echeverría, 2013, 63).

La televisión proporciona elementos subjetivos para los migrantes que necesitan crear un imaginario territorial dentro de otro espacio geográfico, creando sobre estos un dispositivo de cercanía a estas, conectados mediáticamente con noticias, producciones televisivas y así tener un sentido de cercanía.

Pero también la televisión y los medios de comunicación ayudan a los migrantes a insertarse en las sociedades donde se establecen, al 
visibilizar las cotidianidades y particularidades culturales, haciendo la inserción de los migrantes un poco más amigable.

Los individuos, familias y comunidades enteras aceptan algunas, rechazan otras y las combinan en los "mundos imaginados" lejanos de su realidad situada [...] Si este mundo imaginado se convierte en poderoso y persuasivo, algunos individuos pudieran proyectarse a sí mismos en el rol de un migrante en un destino deseado, y esta imaginación pudiera llegar a la migración concreta. Otros pudieran imaginarse a sí mismos en el difícil recorrido hacia los EE. UU. Y pudieran elegir quedarse en su comunidad (Sladkova, 2007: 191).

De esta manera, los medios de comunicación conforman herramientas necesarias no solo para saber sobre los procesos de migración, sino dispositivos de inserción cultural, es decir, funcionan como dispositivos pedagógicos para los migrantes.

\section{Imágenes y sensibilidades de la migración}

Existe una dicotomía sobre las imágenes y la migración, muchas de estas son repetitivas y poseen una carga discursiva de horror, dolor y violencia, y con ello la estereotipada de peligrosidad de los migrantes. No obstante, estas imágenes cada día, son más recurrentes, creando sobre este grupo social estigmas.

Sin embargo, los medios de comunicación han creado una esfera sensible sobre ciertos grupos de migrantes como personas desprotegidas que huyen de sus países por diversas situaciones. Una de las imágenes más sensibles fue la del año 2015, donde se observa un niño sirio muerto a orillas del mar en Turquía que causó conmoción a las audiencias "gracias a Nilufer Demir y a los medios de comunicación sabemos que se llama Aylan Kurdi, que tenía tres años y que murió junto a su hermano de cinco, Galip Kurdi, y su madre" (Pastrana, 2015). Los medios de comunicación son los transmisores de la información, pero también surgen las preguntas ¿hasta qué punto los medios deben informar?, ¿qué realidades nos están informando? ¿Son acaso lo transmisores de unos estereotipos que solamente nos hacen ver una cara de la moneda de este fenómeno denominado migración?

Los migrantes no son solo noticias, son una realidad que, sin duda, cada vez se van insertando como tema de debate. Aunque existe un discurso reiterativo sobre la migración cada vez se pueden observar 
otros tratamientos mediáticos sobre este fenómeno tendientes a sensibilizar a las audiencias, se conserva un discurso negativo creando, en muchos casos, el imaginario de inseguridad que dejan en la sociedad una preocupación.

Hemos tratado el fenómeno de la Inmigración como cualquier otro hecho informativo. Es decir, se ha aplicado a este fenómeno las reglas y los criterios de lo noticiable, que suele coincidir con lo conflictivo, lo polémico y lo controvertido sin pensar demasiado en que, a diferencia de otros acontecimientos contados como noticias, éste fenómeno carece de un contexto previo (Ortega Dolz, 2004).

En este contexto, y al aplicar los criterios de lo noticiable, la televisión se ha convertido en ese espacio que visibiliza las experiencias de una sociedad en la que los migrantes han creado espacios donde se van insertando, "la presencia habitual de la inmigración en los medios indica que nos encontramos ante un proceso que preocupa a las instituciones, genera controversia social, provoca la adaptación de los discursos ideológicos (...) y genera una enorme masa de contenidos informativos" (Xambó, 2010: 161).

\section{Bibliografía}

Abruzzese, M. (2002). Zapping. Sociología de la experiencia televisiva. Madrid: Cátedra.

Adorno, T. (1964). La televisión. Caracas: Monte Ávila.

Bajtin, M. (2003). La cultura popular en la edad media y en el renacimiento. Madrid: Alianza.

Baricco, A. (2008). Los bárbaros. Barcelona: Anagrama, 2008.

Benjamin, W. (2010). La obra de arte en la época de su reproductibilidad técnica. Quito: Rayuela ediciones.

Bourdieu, P. (1997). Sobre la televisión. Barcelona: Anagrama.

Echeverría, M. (2013). Cultura migratoria y comunicación masiva e interpersonal en los imaginarios juveniles. Comunicación y sociedad, (19), 61-86. Recuperado en 08 de noviembre de 2018, de

http:/ / www.scielo.org. $\mathrm{mx} /$ scielo.php?script=sci_arttext\&pid= S0188-252X2013000100004\&lng=es\&tlng=es. 
Debord, G. (2008). La sociedad del espectáculo. Buenos Aires: La Marca Editora.

García Reina, L. (2004). Juventud y medios de comunicación. La televisión y los jóvenes: Aproximación estructural a la programación y los mensajes. Ámbitos, 115-119, de https://www.ull.es/publicaciones/latina/ambitos/1112/archivos11_12/reina.pdf

González Requena, J. (1992). El discurso televisivo: espectáculo de la posmodernidad. Madrid: Cátedra.

Grimson, A. Varela, M. (1999). «Audiencias, cultura y poder» En Audiencias, cultura y poder, de Alejandro, Varela Mirta Grimson, 197, 198. Buenos Aires: Eudeba.

Imbert, G. (2003). El zoo visual. Barcelona: Gedisa.

La Nación. (2001). ¿Una sociedad light?, de https://bit.ly/2Nwgygp Lipovetsky, G. (2006). El imperio de lo efímero: la moda y su destino en las sociedades modernas. Barcelona: Anagrana.

Machado, A. (2000). El paisaje mediático. Buenos Aires: UBA/Libros del Rojas.

Martel, F. (2012). Cultura Mainstream. Madrid: Punto de Lectura.

Martín-Babero, J. (2003). De los medios a las mediaciones. Bogotá: Convenio Andrés Bello.

Martín-Babero, J. (2002). Oficio de cartógrafo. Santiago: Fondo de Cultura Económica.

Orozco, G. (2001). Audiencias, Televisión y Educación: Una deconstrucción pedagógica de la "televidencia" y sus mediaciones. España: Revista Iberoamericana.

Ortega Dolz, P. (2004). La inmigración contada. Madrid: Jornadas de Periodismo y de Comunicación. Obtenido de http://www.carm.es/ctra/cendoc/doc-pdf/pub/pub-0051.pdf Pastrana, E. (3 de septiembre de 2015). El Confidencial. Muerte de un ruiseñor: la foto del niño sirio muerto en la playa conmociona al mundo. Obtenido de https://www.elconfidencial.com/mundo/2015-09-03/ninosirio-muerto-orilla-playa-turquia_998584/

Rincón, O. (2003). La televisión industrial. Crisis + entretenimiento. Colombia: La Tadeo, 2003.

Rincón, O. (2006). Culturas mediáticas. Bogotá: Gedisa. Sarlo, B. (1994). Escenas de la vida posmoderna. Buenos Aires: Ariel. 
Sladkova, J. (2007). Expectations and motivations of Hondurans migrating to the United States. Journal of Community \& Applied Social Psychology, 17, 187-202.

Tufte, T. (1997). Televisión, modernidad y vida cotidiana. Guadalajara: Universidad de Gudalajara.

Vargas Llosa, M. (2012). La civilización del espectáculo. Quito: Alfaguara.

Vattimo, G. (2003). En torno a la posmodernidad. Barcelona: Anthropos Editorial, 2003.

Wolton, D. (1995). Elogio del gran público: una teoría crítica de la televisión. Barcelona: Gedisa, 1995.

Xambó, R. (2010). La inmigración en los medios de comunicación. Tendencias Discursivas (23), 161-171. Obtenido de https://www.uv.es/ sociolog/arxius/ARXIUS\%2023/ARXIU S_23_13.pdf 



\title{
“Territorialización 2.0.": la red en los procesos migratorios y los social networks al servicio de las comunidades
}

\author{
Gianluca Gaias \\ Università degli Studi di Cagliari, Italia
}

\section{Resumen}

En un mundo cada vez más conectado y global, donde es difícil definir las categorías de "aquí" y "nosotros", la información y la comunicación se mueven de una manera cada vez más fluida a través de la red y, específicamente, a través de las redes sociales. El uso de estas herramientas permite a individuos y grupos dar vida y participar en comunidades virtuales reales, sentando las bases para la construcción de espacios sociales en todos los aspectos, aunque anclados a una condición física diferente a la del "lugar" entendido en términos materiales. En la puesta en escena de estas "plazas" virtuales, las comunidades tan fragmentadas o, como en el caso de la migración, diseminadas por los cuatro rincones del planeta, pueden reunirse y reconstituirse, persiguiendo un objetivo común independientemente del propósito o el significado de esta unión. En este caso concreto, algunas comunidades de migrantes operan en la web para canalizar el interés hacia la misma comunidad, en un intento de trabajar en la búsqueda de la cohesión interna en otro contexto, disperso y, al menos inicialmente, poco familiar. La reconstrucción de este contacto familiar es solo uno de los objetivos de la constitución de estos "alter-egos" de las comunidades territoriales. De hecho, la aparición de estas comunidades virtuales, paralelas o como resultado de un primer 
ejercicio de "apropiación física" del territorio, representan a todos los efectos un ejemplo de "territorialización 2.0.", insertándose desde "abajo" en una ventana de diálogo abierta y potencialmente accesible a todos, garantizando un lugar relevante en el interior del espacio público global y del territorio urbano contemporáneo.

Palabras clave: Migraciones; Cerdeña; social networks; Cultural Studies

\section{Introducción}

$\mathrm{N}$

O HACE mucho tiempo, un artículo publicado en una célebre revista internacional captó mi atención. En él se relataba el contenido de un video que apareció unos días antes en la cadena televisiva $\mathrm{CNN}^{1}$. Tanto el artículo como el video tenían como objetivo principal mostrar cómo los migrantes construyen una compleja red de relaciones que permite obtener un alto nivel de conocimiento de la ruta migratoria, especialmente en relación a los contextos de asentamiento en el exterior. En aquel video se mostraba cómo los migrantes usan la web, y en especial una de las muchas páginas de Facebook, para movilizarse e intercambiar continuamente informaciones de variada y de diversa utilidad sobre sus viajes.

Las dos fuentes mencionadas anteriormente, muestran de qué manera las posibilidades de diversificar el viaje a través de variadas redes de relaciones podrían dar alternativas al sistema de migración ilegal, llevando a grupos de personas a emprender un viaje separándose de las rutas ilegales que gobiernan la trata de personas en el Mediterráneo. Al margen de que no hubiera evidencias de esta afirmación, lo que es cierto es que el uso de internet, en gran parte por medio de smartphones, no se desarrolla de la misma manera por todo el colectivo migrante. Está claro, por ejemplo, que, a mayores posibilidades económicas, existe una mayor disponibilidad de medios tecnológicos por parte de cada individuo.

La dimensión en la que quiero concentrarme, sin embargo, es de naturaleza sensiblemente diferente. $\mathrm{Y}$ pese a que existen puntos en

\footnotetext{
${ }^{1}$ Aquì el link del articulo y del video: https://edition.cnn.com/2015/09/10/europe/migrant-facebook-refugees/
} 
común con el uso de Internet en general, trataré de manera más específica sobre la emergencia en las plataformas de redes sociales de algunas páginas Facebook, Instagram -y más en general en los social networks- de contenidos de matriz religiosa y comunitaria como respuesta al "dato espacial". De hecho, esto revela algunas dinámicas de asentamiento que dan vida a "nuevas etapas virtuales y reales" de representación política entendida de manera simbólica. Más precisamente, quiero decir que estas formas de comunicación transversal, horizontal y sistemática escapan a la lógica del poder de la comunicación "local", dando lugar a sistemas de auto representación espacial y publica que permiten al grupo o individuo revelarse al "otro", apropiarse del espacio y al mismo tiempo cuestionarse en una plataforma abierta y accesible.

\section{Nuevos territorios sagrados en las ciudades: el ejemplo de Cerdeña}

El proceso migratorio contemporáneo produce una heterogeneidad de flujos sin igual, en comparación con los flujos migratorios y la movilidad que la humanidad había conocido anteriormente. De hecho, en los últimos 30 años, la isla de Cerdeña y otras regiones del sur de la península italiana conocieron gradualmente un proceso de inmigración que colocó a las zonas del sur de Italia dentro un sistema que fue invirtiendo la tendencia migratoria, transformando a estas mismas, de zonas de emigración a zonas de inmigración. Una de las peculiaridades de la experiencia italiana ha sido $-\mathrm{y}$ sigue siendo- una notable fragmentación y globalización de proveniencias geográficas, caracterizándola como diferente de la mayoría de otros países europeos con tradición migratoria más antigua. A esta heterogeneidad de presencias correspondería una igualmente amplia diversidad cultural, de tradiciones y de religiones. Los datos estadísticos lo confirman: por lo que concierne la religión, en Cerdeña, el cristianismo representaría con un $57,6 \%$, la religión mayoritaria por los extranjeros $(32,6 \%$ ortodoxos, $18,4 \%$ católicos, $6 \%$ protestantes, $0,6 \%$ otros cristianos), seguido con el $28.2 \%$ por el islam (en mayor parte sunnî), seguido por hindúes, budistas, sikhs y otros cultos (en porcentajes entre 0.2 y $2.1 \%$ ) (IDOS, 2017). Sin embargo, tanto los datos nacionales o internacionales como los de mayor escala solo pueden establecer una correspondencia general entre las comunidades nacionales $-\mathrm{y}$, por lo 
tanto, el Estado de origen-, y sus contextos religiosos y culturales ${ }^{2}$. Los datos correspondientes al escenario de Cerdeña, que reflejan el escenario migratorio nacional, muestran todavía una imagen parcial: no tienen en cuenta a los migrantes que solicitan asilo y a todos los extranjeros "no regulares" o "ilegales" que se encuentran en el territorio. Por lo tanto, además de las indicaciones generales sobre el tema -que pueden ser engañosas-, los problemas que este tipo de investigación quiere resaltar sólo pueden ser conducidas y desarrolladas con una investigación de campo, favoreciendo los enfoques cualitativos y participativos.

De hecho, este "excursus extraterritorial" fue el análisis de campo que proporcionó informaciones más completas y complejas sobre las dinámicas de asentamiento y las articulaciones de las "religiones migrantes" en el contexto bajo examen. A partir de esta encuesta, observamos cómo el panorama que podemos representar es decididamente más complejo en comparación con los datos proporcionados por los organismos de censo y registro que hemos mencionado anteriormente (IDOS, 2017).

\section{Aparición local y elementos territoriales: variedad del paisaje urbano}

Si dejamos a un lado los datos numéricos y estadísticos, y nos paramos a analizar el contexto local, observamos cómo la prueba de la aparición espacial de los grupos migrantes en el contexto estudiado no sólo es

\footnotetext{
${ }^{2}$ La estimación de la pertenencia religiosa de los inmigrantes en Italia se centra sobre una metodología que la Inmigración del Dossier Estadístico sigue de su primera edición (1991). La metodología desarrollada, en la falta de otros criterios más exhaustivos, consiste en considerar que las membresías religiosos encontrados en los países de origen, deducibles de la comparación de publicaciones especializadas a este respecto, también pueden aplicarse a las respectivas comunidades emigraron al exterior, a veces haciendo coeficientes medidas correctivas determinadas por la relevancia de los factores de empujar o tirar en particular relevante (pensemos, por ejemplo, en el impulso de emigrar) Cristianos nigerianos o indios). Esto da una imagen cercana a la realidad, excepto que para "afiliación religiosa" nos referimos solo al enlace con un cierto contexto cultural-religioso (sin ninguna posibilidad conocer las posiciones personales de fe del individuo, su predisposición práctica religiosa e incluso conversiones mientras tanto ocurrido). Además, la metodología adoptada encuentra una natural finalización en evidencia empírica (IDOS, 2017).
} 
proporcional al aumento en el número de migrantes o centros de oración. Hay que añadir, de hecho, una serie completa de elementos paralelos y complementarios a éstos, pero de carácter notablemente diferente. Entre ellos, podemos destacar los elementos visuales, auditivos, olfativos o "virtuales" que nacen y se desarrollan a través de la web.

La variedad semántica del paisaje urbano aumenta significativamente con la presencia en el espacio público de la ciudad de nuevas comunidades, cada una con sus propios sonidos, ritmos, colores y aromas. Aunque los migrantes estén en el interior de un paisaje urbano que es expresión de la comunidad que lo ha producido, los mismos introducen aparatos simbólicos y signos territoriales diferentes. Estos signos pueden ser atribuibles a la transformación de áreas territoriales enteras y extendidas, o limitada a yuxtaposiciones en el tejido urbano que generan complejidad dentro del mismo, a veces dando lugar a "espacios intersticiales" (Memoli y Cattedra, 2003) que surgen como elementos de discontinuidad en el contexto del espacio público.

En un espacio urbano en fase de re-determinación, observa Camille Schmoll,

las transformaciones espaciales inducidas por la presencia de los migrantes permiten a los mismos migrantes, a través de la redefinición de una identidad ligada al lugar de nuevo asentamiento, superar algunos problemas relacionados con la distancia desde el lugar de origen. Todo emigrante -mientras se busca una nueva identidad y una progresiva integración con la sociedad de acogida- trae la experiencia y la memoria de su lugar de origen, la organización espacial, social y cultural diferente, en el que se inserta y respeto por el que había desarrollado un sentido de identidad (Schmoll, 2006:4).

Estos elementos participan en la redefinición del orden del espacio público en las ciudades, reconfigurando las funciones elementales del espacio dedicado a la reunión (de culturas), a la discusión, al diálogo o al conflicto (Appadurai, 2001). Además, dan forma a un conjunto polisémico que transforma los ritmos del entorno urbano, con nuevas texturas y movilidad. 
El sistema de afiliación religiosa de las comunidades migrantes es una de las lentes a través de la cual se puede intentar observar este tipo de modificación del paisaje urbano. Las religiones en movimiento son portadoras de formas culturales, lingüísticas, sonoras y gastronómicas diferentes, típicas o características de una población. Se tratan de conjuntos de personas, con rasgos diferentes según la edad, el género, el estado social y, a veces, incluso la procedencia geográfica o la lengua que emplean ${ }^{3}$. Dicho esto, ¿cómo logran estos grupos visibilidad en un espacio público teóricamente abierto y accesible?

Siguiendo a Vázquez y Knott (2014) y Giorda (2015), la apariencia local de diferentes afiliaciones religiosas tiene lugar principalmente a través de tres tipos de asentamientos: place keeping (mantenimiento de lugar), place seeking (buscar un lugar) y place making (hacer el lugar).

A través de este posicionamiento interpretativo, es posible reconducir la aparición de nuevos lugares de culto con estos modos de apropiación espacial, como el punto de partida de un trabajo de estudio e interpretación de su grado de divulgación pública. La práctica del culto y la dimensión sagrada juegan un papel fundamental en la producción y reproducción del espacio social, especialmente cuando se considera en su dimensión diaspórica de "religiones en movimiento": desde la dimensión doméstica hasta una dimensión más ampliada y pública, las comunidades transnacionales se arraigan tanto en su contexto familiar como en los contextos que las mismas comunidades inscriben en las nuevas redes de migración ${ }^{4}$.

Las comunidades o grupos religiosos en cuestión se expresan a nivel espacial a través de la movilidad de sus fieles, sea en la materialidad del

\footnotetext{
${ }^{3}$ Este es el caso, por ejemplo, de las comunidades islámicas en contextos migratorios. De hecho, a menudo la comunidad islámica se compone de orígenes heterogéneos y diversificados en una base lingüística, nacional, geográfica o incluso ritual. Por ejemplo, si pensamos a un centro de culto islámico de una cualquiera ciudad europea: los fieles vendrán probablemente de diferentes partes del mundo, unidos en la participación a los rituales por la fe, y al mismo tiempo, distantes por otras razones como el idioma, rasgo fundamental en la participación en un ritual religioso.4

${ }^{4}$ Específicamente, nos referimos a los países que no se vieron afectados anteriormente por los procesos de migración global, como Italia u otros países europeos en el área mediterránea.
} 
espacio en sí mismo, que en el espacio de comunicación o en los espacios virtuales de la web, así como a través de "performances territoriales", sean diarias o rituales (Knott, 2005).

A partir de esto, se puede ver una correlación entre un cierto grado de visibilidad pública de estos lugares y estas prácticas y las modalidades de asentamiento indicadas anteriormente: por esta razón, las instituciones vinculadas a la religión dominante, que podemos definir religión del establishment (en este caso el cristianismo católico) (Giorda, 2015), implementan aparentemente estrategias de mantenimiento - de resistencia- frente a la concurrencia de nuevas confesiones en el panorama religioso local, como las religiones migratorias, diaspóricas y transnacionales, o también los nuevos tipos de espiritualidad emergente en la escena nacional e internacional. Éstos, a su vez, implementan sobre el territorio estrategias de place making y place seeking. En este sentido, los "espacios migrantes" actúan tanto como estrategias de búsqueda del lugar (buscando un lugar de reconocimiento en el espacio público y/o en la esfera pública urbana) como estrategias de construcción territorial (en cuanto propiamente fabrican y fundan el lugar). Además, desde su creación, todo el proceso migratorio (de principio a fin, desde el origen al asentamiento) ve a las comunidades implementando estrategias de mantenimiento (place keeping), o sea preservando un cierto grado de arraigo territorial a través de los lazos transnacionales con los contextos de origen, a los que se orienta precisamente la idea del lugar sagrado en cuestión (en un sentido físico y simbólico): de la Meca a Roma, de Touba a Cagliari, las instituciones religiosas globales

"shape the transnational migration experience at the same time that migrants chip away at and recreate global religions by making them local and then starting the process anew. Transnational migrants bring particular incarnations of global religion with them, create new forms by combining what they bring with what they encounter, and then reintroduce these ideas, practices, identities and social capital- or what I call social remittances- back to their sending communities." (Levitt, 2003:849).

Dicho esto, incluso el mantenimiento de una relación multilateral de (r)existencia lejos del contexto original puede ser considerado parte de una estrategia más amplia de reconstrucción de la identidad y de 
afiliación, y por lo tanto de mantenimiento (place keeping) de una impronta para la replicación de rasgos originales en lugares "otros".

\section{Formas de la territorialización: ¿la red como instrumento de apropiación territorial?}

Con relación a las formas de "fabricar el territorio" indicadas anteriormente, encontramos el mismo proceso de construcción también en la producción de un espacio virtual, entendido como operación conjunta de place making (construcción) y place keeping (mantenimiento) (Knott, Vázquez, 2014). Por un lado, se trata de la construcción de un espacio virtual en el sentido más tecnológico del término: programación de la página web, identificación de un público, elaboración y contenidos a difundir; por otro lado, se trata también de la conservación de prácticas de pertenencia multiformes, como un acto de apropiación semántica del espacio: lenguaje, símbolos, elementos con una visibilidad disruptiva que se producen y reproducen en el espacio web. Es un proceso de territorialización que se mueve a lo largo de un eje espacial diferente del eje Euclidiano "canónico", en sus evidencias físicas y materiales; además, surge como un medio simbólico de apropiación territorial de la comunidad en el territorio del "otro", actuando a veces como un punto de referencia cultural tanto para quienes emprenden la migración como para quienes desean mantener un fuerte vínculo con la comunidad.

La aparente dicotomía entre lo "real" y lo "virtual" es aquí superada en el sentido geográfico: la incorporación simultánea en una única esfera del espacio "material" -físico y factual que incluye artefactos humanos y relaciones sociales- y el espacio "virtual" simbólico, referido a la representación potencial de la realidad, modelado a través de nombres y símbolos (Giorda, 2001). Es difícil recuperar la distinción entre lo que es virtual y lo que es real. En este sentido, la fuerza de los medios de comunicación y la realidad virtual (nomen omen) es, precisamente, la de crear universos de significado paralelos y complementarios que hoy en día son prácticamente inseparables. Siempre en un sentido geográfico, debido a su función de "puesto de avanzadilla" territorial mencionada anteriormente, se constituye como un elemento de discontinuidad espacial en un sistema basado sobre una cierta fijeza espacial, que se caracteriza por un modelo -lo tradicional, lo occidental y lo italiano- que es puesto en duda también por la aparición de estas 
nuevas formas de interpretar el espacio. De hecho, observa Giorda, el espacio virtual representaría la capacidad del ser humano de ampliar su "espacio vivido" (Fremont, 2005) en un lugar "no-lugar" que no es tan diferente del espacio real. Evidentemente no es un espacio material, pero es real, estructurado, en constante cambio y expansión, suficiente para formar un sistema geográfico diferente que, sin embargo, tiene lazos muy evidentes con el espacio geográfico tradicional (Giorda, 2001). Además, hoy en día la red puede ser considerada a todos los efectos como un aparato tecnológico, una extensión o una prótesis técnica del espacio público cotidiano, y por esto parte integrante de las relaciones que en ella tienen lugar.

En consecuencia, la observación de las prácticas implementadas por un grupo o comunidad en el campo de la realidad virtual es importante para llevar a cabo algunas dinámicas que pueden estar sujetas a elementos de "demostración espacial" (Gaias, 2015) o prácticas relacionadas con la visibilidad del grupo y las relaciones con otros actores locales. Un "Me gusta" o una "Compartir" en Facebook, se traduce en este sentido como un gesto simbólico de reconocimiento que puede ser positivo o negativo, tanto para el individuo como para el grupo.

La breve investigación realizada hasta aquí se ha centrado en la aparición de algunas páginas web (Facebook, Instagram, Twitter, Youtube) directamente relacionadas con la cofradía Sufí de los Mourides de Senegal. Las páginas observadas cuentan con un gran número de seguidores (más de 5.600 en Facebook), son ricas en referencias simbólicas, ya sean objetos, personas físicas, imágenes y fotos con citas o máximas extrapoladas de textos religiosos.

Sin embargo, esta contribución no tiene la intención de proceder como investigación (n)etnográfica, sino que se propone como primer enfoque el de observar desde un punto de vista geográfico algunas referencias que se dirigen al tema de un paisaje urbano en mutación, así como resaltar algunas marcas territoriales, ya sea en un lugar físico o en un lugar virtual y al mismo tiempo real, que contribuyen a cambiar y metamorfosear los espacios y el significado que traen consigo.

Si por un lado la red se constituye como medium capaz de ayudar al individuo en la planificación del viaje y en la construcción -alternativa 
o no- de la ruta migratoria, por otro representa un instrumento de territorialización por las comunidades que en ese territorio se establecen. En un primer momento, las relaciones que el individuo mantiene con el contexto de origen se mueven precisamente a través del canal web. Con el tiempo, estos canales informales de comunicación e intercambio de informaciones pueden constituirse en canales más formales e institucionalizados, o también poseer funciones más específicas. En este caso particular, pude observar cómo el potencial de la comunicación en red permite a la comunidad senegalesa Murid de Cerdeña, y más puntualmente del área metropolitana de Cagliari, operar un tipo de "territorialización 2.0" que da lugar a nuevas formas de representación social y espacial.

Los senegaleses de Cerdeña son una de las poblaciones numéricamente más consistentes en toda la isla. Está formada por unas $4.813^{5}$ personas, la mayoría de las cuales, aunque faltan datos oficiales, pertenecen a la cofradía sufí islámica de la Muridyya ${ }^{6}$. Esta última ha favorecido fuertemente, en los últimos treinta años, la migración transnacional de la población senegalesa, configurándose como un sistema altamente estructurado de comunicación, intercambio y contacto tanto desde el punto de vista social como desde el punto de vista comercial, cultural y político.

A partir de esto, encontramos elementos importantes que se mueven a través de la de la red: seguir y observar la "comunidad virtual (religiosa)" proporciona una información complementaria al intento de observar operaciones de "extraterritorialización" en varios niveles:

\footnotetext{
${ }^{5}$ Datos extrapolados de www.tuttitalia.it, elaboración sobre base ISTAT (Instituto de Estadística Italiano). La población de origen senegalesa es la segunda por número después de la rumana, que ocupa con 4.216 individuos la primera posición, sobre una población inmigrante total de 54.224 personas. ${ }^{6}$ De hecho, no hay evidencia numérica de lo escrito: la información procede de la observación y el trabajo de campo, así como de contactos directos con figuras prominentes de la comunidad o de las asociaciones que gravitan a su alrededor. Además, esta información es susceptible de errores e inexactitudes, también debido a la imprevisibilidad del fenómeno migratorio y la inestabilidad de la situación jurídica del migrante: a veces se encuentran en condiciones de "ilegalidad" debido a la falta de documentos necesarios para la estancia y, por lo tanto, no se consideran como "estables" a efectos de un censo.
} 
desde la participación política a la comunitaria y tanto desde el plano local como de la transnacional.

\section{Material (y) virtual}

Los sistemas de interacción entre individuos, ya sea porque pertenezcan a la misma comunidad o a varios grupos, comunidades o sociedades, han sido fuertemente reafirmados por el uso cada vez más masivo de la red. La circulación de información visual y de contenidos audiovisuales o textuales en el medio web, produce una cantidad de material informativo enorme, que tal vez puede ser de matriz e interés diferente.

Sobre todo por lo que concierne el primer período del advenimiento de formas de sociabilidad web (chat, listas de correo, primeros social networks) algunos estudios sobre el establecimiento de grupos compartidos en el ciberespacio, vieron estas formas de agregación como "asociaciones sin vínculos creadas para compartir un mismo lugar físico, pero basado en un vínculo comunicativo e interactivo entre los sujetos que se mueven en el mismo espacio virtual, y que se configura como un verdadero sistema social des-territorializado (...) (Riva, 2015). Sin embargo, de acuerdo con lo observado, esta relación con el lugar físico, especialmente en el caso bajo estudio, existe y está bien presente, y tanto los city users como los virtual city users, crean y construyen lugares en función de su conexión con otros lugares y otros actores.

El ejemplo de la comunidad Murid es, en mi opinión, extremadamente apropiado. Touba, la principal ciudad religiosa y el segundo centro urbano de Senegal después de la capital, Dakar, es un ejemplo notable de este tipo de encuentro entre lo local y lo global, la tradición y la modernidad (Gueye, 2002). Como también enfatizó Sophie Bava, los diversos centros de agregación de los Murids utilizan nuevas tecnologías para promover la identidad grupal, difundir los valores religiosos y "conquistar" el territorio de Internet (Bava, 2001). La red se pone como complemento y extensión tecnológica del individuo, y también como dimensión paralela del espacio público, constituyendo una forma alternativa de aparición en el discurso público del territorio.

Los sujetos que participan en estas plazas virtuales comparten idealmente el mismo lugar físico, la matriz espacial de la ciudad santa 
de Touba, la "Capitale des Mourides" (Gueye, 2002). Touba es central por la identidad Murid y juega un papel ideológico fundamental en la mentalidad de los miembros de la cofradía. Touba es una "marca" y por eso, su nombre recurre simbólicamente como parte del nombre del objeto virtual: en las páginas Facebook o accounts Instagram o youtube que se refieren a las dahiras ${ }^{7}$ en el extranjero, Touba está a menudo puesta en prefijo al nombre de la ciudad que acoge la dahira: Dahira Touba Cagliari, Dahira Touba Sabadell, Dahira Touba Marrakech, Dahira Touba Granada, etc. Touba es aquí "marca territorial" en un contexto otro.

Si la web permite mantener un cierto grado de despersonalización y des-territorialidad, aparece claro que la construcción de las mismas páginas web tiene dos propósitos principales, ambas de igual importancia. La primera está ciertamente vinculada al contexto de asentamiento: los fieles encuentran en la plaza virtual de Touba un lugar común y una zona de confort telemática a la que remitirse para obtener información sobre las actividades religiosas, y también un lugar común de carácter social, económico y político; el segundo está dirigido directamente a su comunidad en Senegal, funciona como un escaparate de actividades, en un cierto sentido, de la vida de los Murids para el público en Senegal. Además, para volver a las posibilidades que Internet y las telecomunicaciones ofrecen a la migración, esta declinación de las páginas web en cuestión ciertamente también funciona en esa dirección de permitir continuos intercambios e interacciones multinivel en diferentes lugares situados a lo largo y ancho del mundo.

Los participantes y los responsables de la gestión de estos espacios virtuales, al "publicar" videos, fotos y testimonios relacionados con las reuniones, demuestran un cierto grado de apariencia pública y una fuerte afiliación comunitaria, mostrando cómo las modalidades a través de las cuales la proximidad entre individuo, comunidad y religión (aquí

\footnotetext{
${ }^{7}$ La Dahira es una asociación de carácter religioso y social que tiene la función de agrupar los discípulos (talibées, en wolof "estudiantes") de un Marabuto, su guía espiritual. Constituye, tanto en Senegal como al extranjero, una unidad básica para el desarrollo de actividades religiosas en contextos urbanos y ofrece apoyo psicológico y logístico a los migrantes (Paltrinieri Casella, 2006).
} 
la cofradía) persisten y se reproducen en contextos físicamente distantes.

Las páginas, durante el período en el que pude observarlas, han cambiado tanto en relación con los cambios dentro de la comunidad (aumento de la población senegalesa en Cerdeña, diferencias generacionales, etc.) como en relación con el continuo cambio del medium utilizado (diversificación del uso y forma de las principales redes sociales). Con el tiempo, las páginas de la red se han multiplicado; de contenidos exclusivamente en wolof-francés, nuevas páginas nacieron exclusivamente en italiano, también destinadas a extender el sentimiento comunitario en toda la isla: después de Touba Cagliari o Touba Sassari nació la página de Touba Sardegna. Su función, podemos suponer, es tanto la de reconstruir relaciones sociales comunitarias en un contexto cultural post-secular, como es lo italiano, cuanto la de proponer su propia identidad comunitaria al resto de las comunidades que se encuentran en el territorio, a través de la hípervisibilidad que la red les permite de obtener.

Fig.1- Imágenes de las paginas Facebook o Instagram de los grupos de las comunidades Murid de Cerdeña en la web
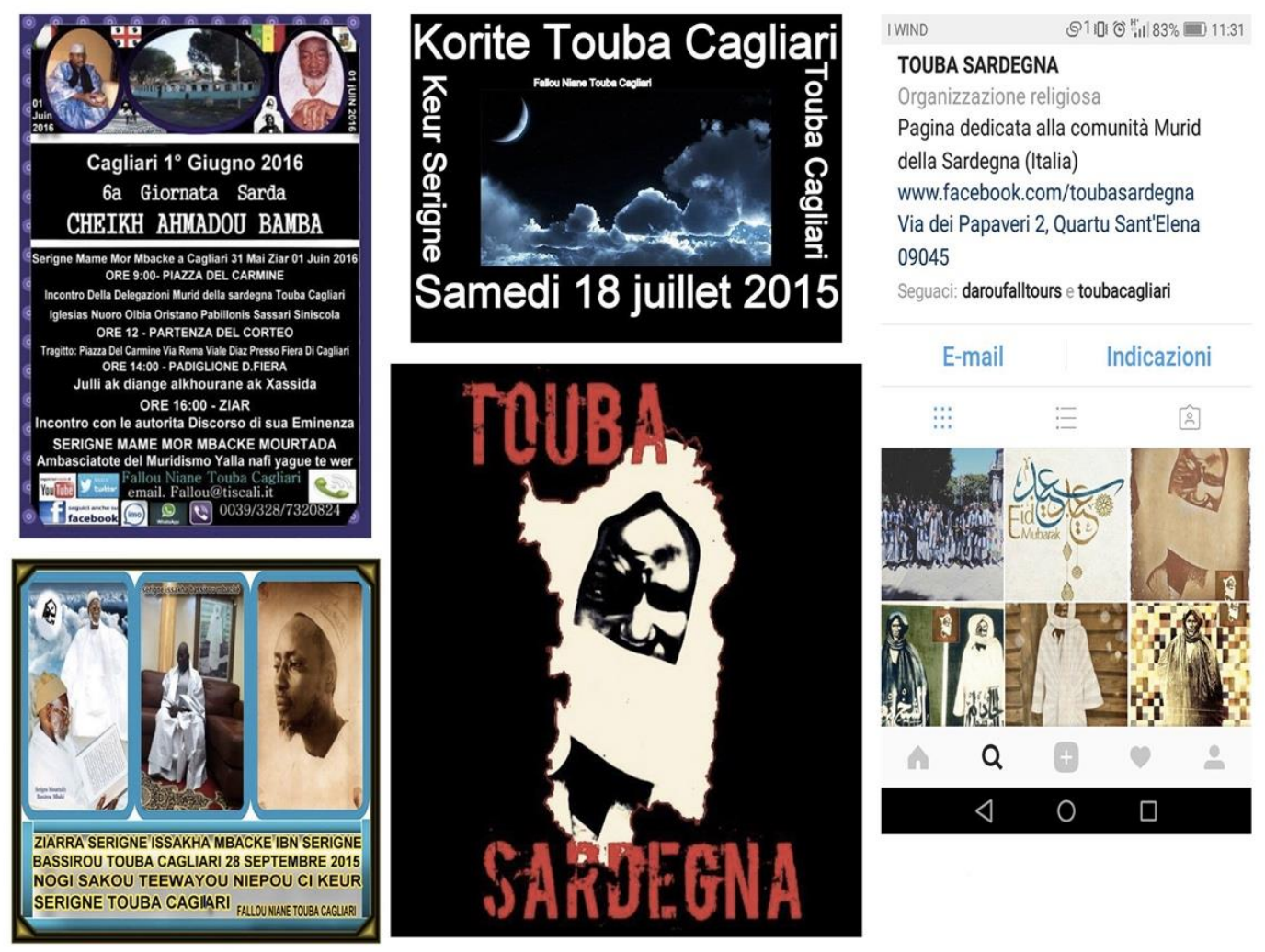

Fuente: Elaboración propia a partir de las páginas de Facebook e Instagram. 
Estas plazas virtuales, en lugar de limitar, como se podría pensar, el uso de espacios físicos de encuentro - y más propiamente públicos, generan diferentes modelos de movimiento a nivel geográfico. Los casos de Touba Sardegna y Touba Cagliari son ejemplares: la información se presenta íntegramente en italiano, idioma vehicular, para diferentes propósitos. Lo primero y más importante es permitir que las nuevas generaciones de sardo-senegaleses participen activamente y aprendan tanto como sea posible sobre el mensaje de Serigne Touba; en segundo lugar, para transmitir de manera positiva a las comunidades locales un mensaje de diálogo y para promover la difusión de una información sobre la comunidad que es tal vez víctima de una visión estereotipada y estandarizada de la realidad. Además, proporcionar una clave de interpretación de una comunidad que va buscando una inclusión en el espacio público y una representación en la esfera local y transnacional, promoviendo así una movilidad del saber religioso del y de la participación transnacional, tanto mediática cuanto física.

Un segundo tipo de movilidad, por otro lado, es la movilidad humana concretamente y materialmente entendida, y a su vez puede tener una doble dirección. Puede configurarse como polo de atracción y interés por aquellos que tengan la intención de emprender una ruta migratoria y encontrar en esta densa red de nodos - las dahiras - una amplia área de referencia sobre la cual proyectar su propia experiencia con la seguridad de encontrar un apoyo local sólido y receptivo ; en segundo lugar, también se promueve la movilidad dentro de la misma isla de Cerdeña, diaria o ritual, ya que la plaza virtual desempeña una función de llamada a las Dahiras en todo el país durante los muchos eventos que la comunidad senegalesa organiza durante todo el curso del año. Las páginas web en cuestión actúan como una antesala o parte de lo que sucede en parte fuera y se refiere a la comunidad Murid.

\section{Conclusiones y reflexiones finales}

Este breve contribución sobre las emergencias virtuales de prácticas, usos y dinámicas relacionadas con el uso de la red en la realidad migrante, lejos de ser exhaustivo, pretende ser un primer acercamiento a la observación, en clave complementaria a otros aspectos relacionados con la migración de personas, objetos, símbolos y culturas, que trata de proporcionar una imagen más completa de la 
dinámica puesta en marcha durante el proceso migratorio y el proceso de aculturación territorial de las comunidades migrantes.

Lo que podría aportar la investigación de este fenómeno social producido por los migrantes transnacionales y las comunidades de la diáspora, se puede estructurar en diferentes líneas de investigación: un primer punto de interés cubriría principalmente el factor de la "visibilidad", o la capacidad de aparecer en un "lugar" como la web, dinámica y espacio de participación, que permite ser visibles en el contexto de acogida y abre potencialmente al dialogo con el "otro"; una segunda línea se refiere al factor "reconocimiento" y incluye no sólo el intento de un reconocimiento efectivo de una identidad en el contexto de asentamiento, sino un proceso más amplio de intercambio, de "aculturación bilateral" y de producción simbólica que permite al migrante reconocerse y ser reconocido como un "sujeto cultural"; un tercero (más implícito y también referido a los primeros dos), enfatiza una falta de ciudadanía y se configura como un proyecto de autoorganización y auto-representación espacial: el ciberespacio representa un entorno que se "encaja en la escala espacial de la vida cotidiana ", y precisamente por su característica de moverse tanto a nivel local como a nivel translocal, "asume (...) de esta manera el valor de un espacio geográfico en todos sus aspectos"(Giorda, 2001: 98). Al hacer esto, en la planificación, uso e intercambio de un espacio virtual y real, los grupos son capaces de organizar y dar vida a algo que falta en el espacio público, creando procesos innovadores de participación desde abajo, que reestructuran el espacio físico de la ciudad y permiten nuevas lecturas de un paisaje urbano en continua mutación.

Las posibilidades de futuras investigaciones partiendo desde Touba Cagliari, con el objetivo de profundizar en las redes que se mueven en una diversidad de escalas (Touba, Cagliari, Sassari, Cerdeña, Touba Italia Ontevico, Brescia), nos permitirá leer ciudades como Cagliari o Granada -ciudades provinciales, más pequeñas que las grandes capitales- como nodos de un sistema de comunización global y transnacional que nos ayudan a reinterpretar estos espacios urbanos. Pequeñas ciudades en donde se asientan grupos o comunidades migrantes y que se proyectan como escenarios compartidos y fragmentados en donde la diversidad se configura como la matriz fundamental. 


\section{Bibliografía}

Appadurai, A. (2001). Modernità in polvere. Dimensioni culturali della globalizzazione. Roma: Meltemi.

Bava, S. (2001). Routes migratoires et Itineraires religieux. Des mourides entre Marseille et Touba. Dakar: Panafrika - Siles Nouvelles du Sud

Bignante, E. (2011). Geografia e ricerca visuale. Strumenti e metodi. Bari: Laterza.

Cattedra, R. \& Gaias, G. (2019). Costruzioni territoriali e migrazione. Spazi del sacro e identità religiose a Cagliari. Atti XXXII CGI L'apporto della Geografia tra rivoluzioni e riforme. Roma: A.Ge.I.

Cattedra, R. \& Memoli, M. (2013). Spazi di "nuova Italia": situazioni cosmopolite e forme di eterotopia. Aru, S., Corsale, A. \& Tanca, M. (eds). Percorsi migratori della contemporaneità. Forme, pratiche, territori. Pp. 83-98, Cagliari: Cuec

Frémont A. (2005). ¿Vi piace la geografía? Roma: Carocci editore.

Gaias, G. (2016). [Spazi migranti. Luoghi, suoni e volti di un paesaggio urbano dell'immigrazione.] Unpublished raw data.

Giorda M. C., (2015). "I luoghi religiosi a Torino. Le religioni nei contesti urbani contemporanei", Quaderni di diritto e politica ecclesiastica, 2 (8), pp. 339-358

Giorda, C. (2001). Cybergeografia. Estensione, rappresentazione e percezione dello spazio nell'epoca dell'informazione. Torino: Tirrenia stampatori.

Gueye, C. (2002). Touba. La Capitale des Mourides. Paris: Eid Kharthala

Gueye, C. (2003). New Information and Communication Technology Use by Muslim Mourides in Senegal, Review of African Political Economy, 30(98), pp. 609-625

IDOS, (2017). Dossier statistico Immigrazione, Roma.

Knott, K. (2005). Spatial Theory and Method for the Study of Religion. Leeds: University of Leeds

Paltrinieri Casella, A. (2006). (ed.), Un futuro in gioco. Tra Muridi Senegalesi e Comunità italiana. Milano: Franco Angeli.

Piangerelli, L. (2004). Tribale e globale: internet e le metamorfosi della comunicazione, Rivista trimestrale di studi e 
documentazione dell'Istituto italiano per l'Africa e l'Oriente, 59 (3/4), pp.- 466-480

Riva, C. (2005). Spazi di comunicazione e identità immigrata. Roma: Frano Angeli

Turco A. (2010). Configurazioni della territorialità. Milano: Franco Angeli

Vazquez, M.A. \& Knott, K. (2014). Three dimension of religious place making in diaspora, Global Networks 14(3), pp. 326-347. 



\title{
Usos de las lenguas y preferencias lingüísticas entre inmigrantes y refugiados
}

\author{
Rosella Bianco \\ Instituto de Migraciones, Universidad de Granada, España \\ Mónica Ortiz Cobo \\ Departamento de Sociología, Instituto de Migraciones, Universidad \\ de Granada, España
}

\section{Resumen}

El proceso migratorio se relaciona directamente con el aprendizaje lingüístico de manera natural, porque el migrante aprende espontáneamente la lengua del país de la migración. Por otro lado, el aprendizaje de esta lengua se liga a otro tipo de aprendizaje, el requerido por las políticas migratorias como requisito para acceder y permanecer en un país europeo. En este panorama, no se tienen en cuenta las necesidades reales de quienes migran, ni el repertorio lingüístico que ellos disponen. Este trabajo presenta un análisis etnográfico, desarrollado a partir de un periodo de observación participante en clase de italiano como segunda lengua durante el cual se han realizado entrevistas y cuestionarios a sujetos inmigrantes y a refugiados. Con esta investigación se ha pretendido analizar los usos y las preferencias lingüísticas reales de estos sujetos, para conocer cuáles son las relaciones reales de quien migra con las lenguas conocidas y las de aprendizaje. Los resultados obtenidos reflejan la particularidad en los usos y las preferencias lingüísticas entre el colectivo de inmigrantes y refugiados, los cuales se distinguen debido al diferente origen migratorio de los mismos. 
Palabras clave: Refugiados, inmigrantes, lenguas, migración, actitudes.

\section{Introducción}

Z L AUMENTO de las migraciones hacia Europa ha comportado migratorios. Bajo el punto de vista lingüístico, las políticas migratorias presentes en varios países de Europa han considerado la lengua como factor de acceso al país de la migración. En otros casos, de manera similar a este tipo de requisito, el factor lingüístico tiene un papel importante en la posible permanencia del inmigrante en el país europeo (Pulinx, Van Avermaet \& Extramiana, 2014). De esta manera, las certificaciones y conocimientos lingüísticos son no solo parte del propio equipaje cultural, sino que han adquirido un carácter administrativo y legal. Es decir, el conocimiento lingüístico, requerido en nombre de la integración sociocultural en el país de inmigración, llega a jugar un papel importante en el control y en la gestión de la migración. Por otro lado, la imposición del aprendizaje de la lengua y en algunos casos de fundamentos de educación cívica (véase el llamado "acuerdo de integración" italiano regulado por el art. 4-Bis T.U. sull'immigrazione N. 286/98) se coloca en el seno de una dinámica asimilacionista común a los países europeos (Locchi, 2012; Catarci, 2014).

Por otro lado, hay que señalar que la crisis de asilo ha sido asociada a la necesidad de control de la inmigración, descuidando casi completamente otros factores, entre los cuales destaca el factor educativo (Pinson y Arnot, 2007) y de manera más general la atención a las necesidades educativas de este colectivo particular de estudiantes.

A este propósito, es importante tener en cuenta las complejidades de las identidades lingüísticas de los migrantes. Por un lado, señalar el proceso continuo de aprendizaje lingüístico al cual ellos están sujetos durante la migración, siendo influenciados por la situación lingüística y las políticas lingüísticas del país de la migración. Gracias a ello, estos sujetos llegan a tener (o a ampliar) un repertorio lingüístico plurilingüe. Por otro lado, es imprescindible considerar la relación con las primeras 
lenguas (L1). Ellas están directamente conectadas con la identidad personal y por ello, en caso de que estén relacionadas con violencia y persecución vividas en sus países de origen, algunos migrantes quieren dejarlas atrás. De manera contraria, en el caso de otros migrantes, las lenguas nativas se reflejan en un sentimiento de pertenencia que se necesita promover, siendo estas lenguas la representación del único elemento de estabilidad en sus vidas precarias (Krumm \& Plutzar, 2008).

A la luz de estos factores, es necesario profundizar sobre cuáles son las necesidades lingüísticas reales de quien migra, lo que representa un objeto de estudio escasamente tratado en la literatura. Además, como sugieren las diferentes relaciones identitarias que los migrantes pueden establecer con la lengua, en este análisis resulta necesario atender a los varios tipos y sujetos de migración. En primer lugar, es esencial considerar las diferentes experiencias migratorias que tienen los refugiados frente a los inmigrantes económicos o familiares. El proceso migratorio de los primeros es netamente distinto de los otros dos, tanto en lo que se refiere al recorrido migratorio como a la permanencia en el país de la migración. Pensemos en los riesgos que los refugiados suelen encontrar durante el viaje hacia el país de acogida, además de la situación administrativa que los solicitantes de asilo tienen en este país, viviendo situaciones que Campesi (2011) relaciona con la detención.

Por supuesto, la migración está relacionada con el aprendizaje de lenguas, pues en los países de migración los sujetos se enfrentan a nuevas lenguas y culturas diferentes a la propia. Por lo tanto, de manera espontánea o también formal, aprenden la lengua del país de migración (Blommaert y Backus, 2013; Franceschini, 2006).

En este panorama, cabe destacar el potencial lingüístico de quien migra, el cual alcanza un repertorio lingüístico plurilingüe con niveles de competencias diversificados en las lenguas aprendidas según las específicas necesidades del contexto migratorio vivido. Finalmente, señalar que este resultado lingüístico de la migración se relaciona con los objetivos lingüísticos expresados por el consejo de Europa, el cual aspira a la difusión de competencias lingüísticas plurilingües y variadas (Landone, 2004; Consejo de Europa, 2002). 


\section{Presentación de los objetivos del estudio}

A partir de este contexto teórico, este trabajo se propone analizar las relaciones que los inmigrantes y refugiados tienen con las lenguas. Específicamente, para ello nos hemos planteado los siguientes objetivos:

- Observar e investigar la competencia lingüística de refugiados e inmigrantes en las varias lenguas conocidas y utilizadas;

- Analizar los usos de las lenguas habladas por inmigrantes y refugiados;

- Identificar particularidades en las preferencias lingüísticas en ambos colectivos.

Para lograr estos objetivos, se ha analizado el complejo de relaciones de dichos aprendices con las lenguas habladas, atendiendo a los usos y contextos de cada lengua y a los motivos de la preferencia en la elección de la lengua utilizada según contextos.

\section{Metodología}

Para realizar esta investigación se ha empleado una metodología etnográfica que ha permitido la aproximación a los sujetos y al contexto de la investigación de manera natural. Se ha llevado a cabo un trabajo de campo prolongado, el cual nos ha permitido integrarnos en el contexto de investigación, además de conocerlo sin filtros, directamente, y en profundidad (Alvarez, 2008).

Para este estudio, se ha utilizado los siguientes instrumentos: la observación participante, el cuestionario y la entrevista informal. La entrevista nos ha permitido complementar el cuestionario para profundizar en los datos recogidos y contrastarlos, pudiendo triangular los instrumentos de recogida de información.

La observación se ha realizado en cuatro clases de italiano en Salento, Italia. En una clase de un centro que se ocupa de la acogida de los solicitantes de asilo y refugiados y en tres clases de un centro para la educación de los adultos. A lo largo del artículo, estas entidades serán nombradas a través de códigos identificativos, con el objetivo de proteger la identidad y garantizar el anonimato de las mismas. De la misma manera se procederá con los sujetos informantes. Es decir, se 
utilizará el acrónimo CEA para referirse al centro de educación de los adultos y CAR para el centro de acogida de los refugiados. Además, para nombrar a los informantes se utilizará un código compuesto por "R" para el colectivo de refugiados e "I" para los inmigrantes. Estas letras irán seguidas por un número con el fin de diferenciar los informantes pertenecientes al mismo colectivo. Por último, se indicará el país de procedencia del informante (ejemplo: R2 Guinea, I1 Brasil).

En lo que se refiere al periodo de observación participante, este se ha llevado a cabo durante dos meses de asistencia diaria a las clases. Este contacto cotidiano ha permitido la aproximación a los sujetos del estudio. Acercarse a ellos, sobre todo al colectivo de refugiados, no ha sido fácil. Es común que los refugiados asocien situaciones similares a las entrevistas con los procedimientos legales inherentes a las solicitudes de asilo, lo que a menudo genera en ellos un sentimiento de estrés. Así que, la relación prolongada con ellos ha ayudado a establecer relaciones de confianza, esenciales para el desarrollo de la investigación.

Durante las sesiones de observación participante, además, se ha aprovechado para administrar el cuestionario y realizar las entrevistas informales. Más en detalle, el cuestionario ha constado de cincuenta y cuatro preguntas de respuestas tanto abiertas como cerradas, divididas en tres partes. Una primera parte hace referencia a la motivación y expectativas, una segunda parte aborda los usos de las lenguas habladas y una tercera recoge la relación del estudiante con el aprendizaje del italiano. La administración del cuestionario se ha realizado de forma escrita y de forma oral en los casos en que el nivel educativo no permitiera la administración escrita. Esto porque algunos aprendices de la muestra están escasamente alfabetizados mientras que otros, aun estando alfabetizados, han tenido dificultades en la lectura y comprensión del texto. Por este motivo, algunos cuestionarios iniciados de manera escrita se han continuados oralmente.

Por lo que se refiere a las entrevistas, ellas han sido realizadas en varias sesiones, durante la observación participante. El tipo de entrevista utilizado ha sido el informal, que ha permitido de un modo relajado lograr la visión subjetiva de los entrevistados y profundizar en su relación con la lengua italiana. Usar una modalidad más formal de entrevista probablemente habría condicionado su actitud y respuestas. 
Por este motivo se ha optado por un acercamiento lo más natural posible.

En total, se han administrado treinta y tres cuestionarios (veintitrés refugiados y diez inmigrantes) y once entrevistas (seis refugiados y cinco inmigrantes). Los cuestionarios se han repartido entre tres clases del CEA: diez cuestionarios en la clase 1 , doce en la clase 2 y once en la clase 3. Las once entrevistas se han realizado también en tres clases: tres en la clase 1 , tres en la clase 2 y cinco en la clase 3.

Durante la investigación, ha sido necesario el uso de diversas lenguas, a causa del bajo nivel de italiano de muchos estudiantes. Se ha utilizado el portugués, el inglés, el francés, y el árabe. Estas lenguas han permitido la comunicación con todos los aprendices a excepción de dos, pues uno únicamente hablaba criollo y el otro bengalí. Algunas veces nos hemos servido de los estudiantes en calidad de mediadores lingüísticos y hemos empleado más de una lengua.

En cuanto a la muestra, hemos contado con la participación de treinta y tres individuos de entre dieciséis y cuarenta años. De ellos, veintitrés son refugiados y diez son inmigrantes. Los dos colectivos viven en Italia hace poco, por un periodo que oscila entre un mes y tres años. La procedencia de los estudiantes está repartida del siguiente modo: dos aprendices de Somalia, siete de Nigeria, uno de Egipto, uno de Marruecos, uno de Mauritania, uno de Guinea, uno de la Costa de Marfil, uno de Guinea Bissau, tres de Gambia, uno de Ghana, uno de Sierra Leona, uno de México, uno de Colombia, uno de Argentina, uno de Brasil, uno de Ucrania, dos de Polonia, dos de India y dos de Pakistán. En suma, dieciocho aprendices proceden de África Occidental, dos del Norte de África, dos de África Oriental, cuatro del Sur de Asia, cuatro de América del Sur y tres de Europa del Este.

\section{Evidencias}

\section{Lenguas habladas y competencia plurilingüe}

La competencia comunicativa (o competencia oral) de los dos colectivos es generalmente plurilingüe (veintinueve de los treinta y tres informantes). Solo cuatro sujetos (dos refugiados y dos inmigrantes) han declarado hablar una sola lengua. Las lenguas habladas por el colectivo de los refugiados son: edo, esan, twi, fula, wolof, mandinka, soninké, diakanké, balanta, criollo, dyula, yoruba, hausa, somalí, árabe. 
Debido a la gran presencia de hablantes africanos, la mayoría de las lenguas presentes en el colectivo de refugiados pertenecen a los grupos de lenguas nigerocongolesas y afro-asiáticas (las lenguas nigerocongolesas son aquellas de la familia de lenguas que se habla en la región de África por debajo del Sahara hasta Sudáfrica, mientras que las afroasiáticas forman una macrofamilia de doscientas cuarenta lenguas habladas en el Norte de África, África Oriental, el Sahel y Oriente Medio). También están presentes, aunque minoritariamente, lenguas del grupo indo-iraní, subgrupo de la familia indoeuropea (grupo lingüístico del protoindoeuropeo, lengua de la cual deriva la casi totalidad de las lenguas que han tenido origen en el espacio que va desde el occidente de Europa hacia parte de Asia central y del sur).

Además, casi todos estos estudiantes hablan una lengua colonial: francés, inglés o portugués. En siete casos, las lenguas habladas por los refugiados son idiomas que identifican grupos étnicos que se extienden fuera del área nacional de un país y que son dialectos de una misma lengua y por ello mutuamente inteligibles. Así que, refugiados de países próximos se comunican sin ninguna dificultad, aun no compartiendo la misma nación de origen. De hecho, muchos de ellos proceden de naciones multilingües y multiétnicas y tienen competencias lingüísticas no solo en la lengua de su grupo étnico sino también en otras, disponiendo de competencias plurilingües. Estas competencias, a veces se limitan solo al ámbito de la comprensión (es decir entender un texto escrito y/o un discurso oral), mientras que otras veces se extienden también a la producción (o sea a la capacidad de utilizar la lengua oralmente y/o por escrito). Por ejemplo, es el caso de los hablantes de la lengua wólof, del mandinka, del soninké y de la fula (el wólof se habla en Gambia, Senegal y Mauritania; el Mandinka en Senegal, Gambia y Guinea Bissau; el soninké en Costa de Marfil, Gambia, Guinea, Guinea Bissau, Mauritania y Senegal; la Fula es una lengua hablada en Guinea, Gambia, Camerún, Sudan y Senegal). También se da el caso de lenguas similares como el hindi, el punjabi y el urdo, que permiten el mutuo entendimiento entre ciudadanos pakistanís e indianos.

También la procedencia del colectivo de inmigrantes es variada, encontrándose la sudamericana, indiana, norteafricana y de países del este de Europa. También en este caso, casi todos hablan más de una lengua y conocen lenguas vehiculares (lenguas utilizadas para lograr la 
comunicación entre personas que no hablan la misma lengua, pero conocen una lengua en común). Las lenguas habladas por el colectivo de los inmigrantes son: español, portugués, hindi, punjabi, polaco, ruso, ucranio y árabe. Es decir, lenguas del grupo indoeuropeo, más específicamente el grupo eslavo, latino e indo-iraní pero también en el caso de la lengua árabe, lengua semítica, del grupo afroasiático. En cuanto a las lenguas vehiculares, este colectivo logra comunicarse con los otros compañeros de clase principalmente a través del español y el inglés.

Respecto a la competencia escrita, en lo que se refiere a los refugiados alfabetizados en su lengua, no siempre la competencia oral de una segunda lengua implica la competencia escritora de la misma. Hay por ejemplo quien habla urdo e inglés, pero está alfabetizado sólo en la primera lengua, no obstante, la lengua inglesa es, junto al urdo, lengua oficial del Pakistán. Por ello, aprende el sistema alfabético inglés a través de la alfabetización en italiano. Los inmigrantes que participan en este estudio, al contrario, están alfabetizados en todos los sistemas fonéticos de las lenguas que hablan.

El mutuo entendimiento entre dialectos permite la comunicación y la socialización en clase entre varios estudiantes, así como la competencia oral en lenguas coloniales/vehiculares tal como el inglés, el francés y el portugués. En los dos colectivos estudiados, la lengua vehicular predominante es el inglés, hablada por veintiún de treinta y tres aprendices. A excepción de un estudiante mauritano, otro egipcio, un colombiano y una argentina, todos los estudiantes son plurilingües y hablan de una a un máximo de cinco lenguas. Las lenguas francas (LF) permiten la comunicación no solo entre algunos grupos de aprendices, sino también entre los estudiantes y el docente, siendo vehiculares durante las explicaciones en clase. Otras veces, la lengua vehicular puede ser al contrario un motivo de exclusión. Así se pone de manifiesto en expresiones empleadas con frecuencia del tipo: "Yo no he entendido, profesora, porque hablas inglés" (R1, Egipto).

Para concluir subrayaremos que los dos colectivos se caracterizan por competencias plurilingües y que, a pesar de que éstas no siempre se reflejan en habilidades escritoras, representan una gran ventaja desde el punto de vista comunicativo y relacional. De hecho, lo que emerge es que el conocimiento de varias lenguas permite el mutuo 
entendimiento entre aprendices de origen diferente, por un lado, entre individuos de países próximos, gracias a lenguas ligadas a grupos étnicos y por el otro, entre sujetos procedentes de países aún lejanos, gracias al conocimiento de lenguas de origen colonial.

\section{Lenguas y uso}

\section{Usos lingüísticos de los refugiados}

A través del análisis de los datos recogidos en el campo, se ha evidenciado como la peculiar condición de migrantes forzados influye en la posibilidad de hablar y elegir qué lengua utilizar en los contextos de vida cotidiana. Ellos no tienen ningún lazo familiar en Italia y casi todos están solos en dicho país. De veintitrés refugiados solo uno declara estar en Italia con su familia y solo siete declaran tener amigos. Se trata en la mayoría de amistades nacidas en Italia, en el caso de aquellos refugiados que llevan más tiempo en el país y con cuyas amistades se comparte la lengua nativa o el conocimiento de una LF. Es decir, todos los sujetos de este colectivo viven en casas gestionadas por organizaciones financiadas por el gobierno y comparten habitaciones con otros refugiados de varias nacionalidades. Así que, la posibilidad de hablar una u otra lengua depende del azar, si les toca vivir con alguien que comparte la(s) misma(s) lengua(s). En la mayoría de los casos, la lengua materna es hablada puntualmente solo por teléfono con los parientes que viven en el país natal. Son excepción seis sujetos que comparten la casa con connacionales, además de con otros. El resto de refugiados (diecisiete sujetos), para comunicarse con los compañeros de casa utilizan una LF, la mayoría inglés e italiano (en esta última lengua a un nivel casi siempre muy bajo). Esto implica que no siempre se dispone de una lengua compartida y por tanto la comunicación resulta imposible. Además, la permanencia en una casa no es estable porque cada ocupante se queda por un tiempo limitado y a menudo a los ocupantes se les pide cambiar de casa por motivos organizativos. Luego la posibilidad de hablar una u otra lengua es sometida a continuos cambios.

Consiguientemente, se suele utilizar una LF como el inglés para comunicarse con los otros compañeros y solo cuando no hay otra lengua compartida se intenta hablar en italiano. Al respecto recogemos la afirmación de un informante, registrada durante las sesiones de 
observación: "Con los italianos y otros países que no hablan inglés, esta es la sola manera para hablar" (R2, Nigeria). Además, los que trabajan en las organizaciones de acogida están generalmente formados para hablar con los refugiados siempre y solo en italiano.

También, se les pide la asistencia a los cursos de italiano impartidos por el CAR, y se les inscribe en otros cursos de italiano organizados por los CEA, así que en estos casos reciben dos cursos de lengua italiana simultáneamente. Por otro lado, el uso del italiano en el tiempo libre tampoco parece ser de libre elección entre este colectivo. Muchos declaran no poder ver la televisión en otra lengua porque la casa donde viven dispone solo de canales italianos. No falta quien sufre por esta situación, sirva como muestra lo que el informante R3 nos dice: "Lo que yo propio no soporto es que no puedo vivir sin escuchar la música de mi país y aquí no sé cómo hacer" (R3, Guinea Bissau). Al respecto cinco de seis entrevistados utilizan los móviles para ver videos o escuchar músicas en su propia lengua, ya que no disponen aún de ordenadores y televisión en lengua nativa. En el tiempo libre los que conocen connacionales se reúnen, momento que también es empleado para realizar llamadas a la familia, por este motivo el uso de la lengua materna aumenta. En el gráfico 1 se representa el uso de las lenguas habladas en función del contexto: tiempo en casa y tiempo libre. Se hace referencia a estos dos contextos porque ninguno de los refugiados trabaja todavía y porque las actividades formativas proporcionadas por la organización de acogida se desarrollan en casa. Así que es posible diferenciar entre las lenguas utilizadas con los profesionales de la organización de acogida y con los otros refugiados con los que se viven y las lenguas utilizadas con las personas que se eligen libremente, o sea con los que se decide compartir el tiempo libre, sean ellos connacionales o no. A diferencia de lo que se produce en clase, donde muchas son las posibilidades de contacto lingüístico debido a la variedad en la procedencia de los estudiantes, en los dos contextos aludidos no se utilizan lenguas de grupos étnicos diferentes del propio para comunicarse. En casa y en el tiempo libre, las lenguas de comunicación resultan ser las lenguas maternas y lenguas francas tales como el italiano, el inglés, el francés y el árabe. Estas lenguas vehiculares, junto a sus propias lenguas maternas, permiten la comunicación entre nuestros informantes refugiados y los sujetos con 
los que se relacionan en los dos contextos principales de su vida en Italia.

Gráfico 1. Uso de las lenguas según el contexto - refugiados
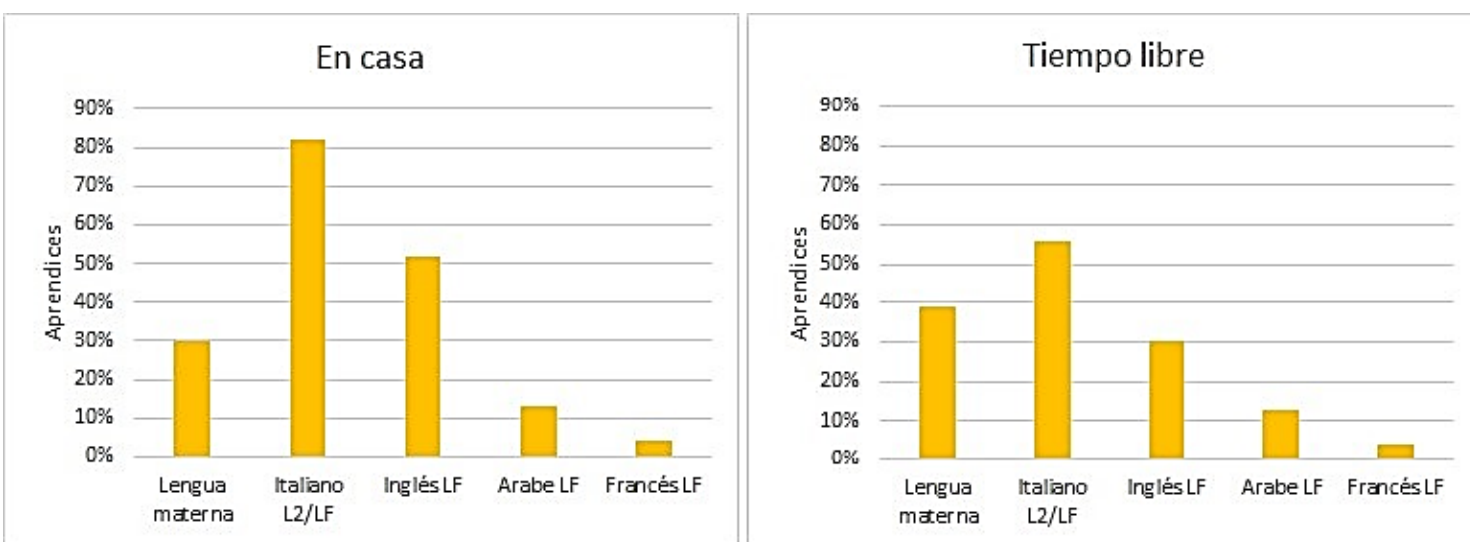

Fuente: Elaboración propia a partir de los datos recogidos en el campo

Como se muestra en el gráfico 1, el uso de la lengua materna es mayor en el tiempo libre que en casa. Casi el 40\% de los informantes la utiliza en el tiempo libre, mientras que en casa el 30\%. Sin embargo, la tendencia se invierte al considerar el uso del italiano y el inglés. El italiano es hablado por más del $80 \%$ de los sujetos en casa como LF con los profesionales de la acogida y con los otros refugiados, sin embargo, en el tiempo libre disminuye al 56\%.

\section{Usos lingüísticos de los inmigrantes}

$\mathrm{Al}$ analizar el colectivo de inmigrantes, utilizamos los mismos contextos de uso para poder hacer una comparativa e identificar diferencias entre colectivos.

El uso y los contextos de uso de las lenguas cambian cuando nos referimos a los inmigrantes. Ellos viven casi todos (nueve de diez) con la familia o con parientes de su familia. Y cuando no viven con la familia, viven con connacionales. Así que el uso de la lengua nativa está garantizado en casa y en las conversaciones telefónicas. Diferente es la situación de aquellos cuyo cónyuge es italiano. En estos casos (sobre todo en parejas con hijos), a la(s) lengua(s) nativa(s) se añade la lengua italiana que se utiliza con el cónyuge y los hijos. Además, las lenguas utilizadas en el tiempo libre serán las mismas que las empleadas en casa, concretamente la lengua materna y el inglés se utilizan en la misma 
medida en ambos contextos, aunque se da un aumento muy marcado (de un 60\%) del uso del italiano en el tiempo libre, tal y como se refleja en el gráfico 2:

Gráfico 2. Uso de las lenguas según el contexto - inmigrantes

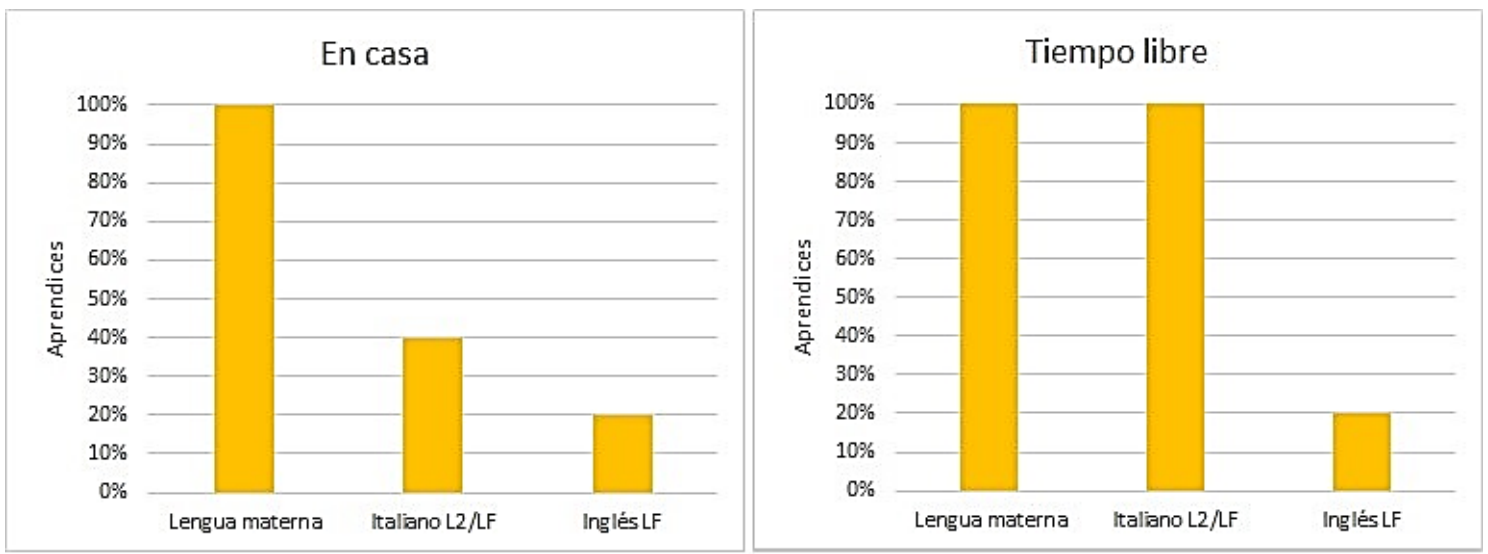

Fuente: Elaboración propia a partir de los datos recogidos en el campo

En este caso, el uso del italiano no está dictado por la condición, sino que se trata de una libre elección del individuo, que ha sufrido un proceso migratorio de carácter voluntario por motivos laborales o familiares. Además, comparando los datos referido a refugiados e inmigrantes, los segundos utilizan menos lenguas francas, debido a su origen y en consecuencia a su competencia lingüística. Mientras que el colectivo de refugiados utiliza como LF el italiano, el inglés, el francés y el árabe, los inmigrantes utilizan como LF solo el italiano y el inglés. El colectivo de inmigrantes se distingue también por el uso de televisión, revistas e internet/ordenador. Disponen de la posibilidad de elegir la lengua de uso de estos medios al contrario que los refugiados, todos poseen un televisor y un ordenador.

\section{Preferencias lingüísticas}

\section{Preferencias lingüísticas de los refugiados}

En nuestra investigación hemos cuestionado sobre las lenguas que les gustaría aprender al colectivo de refugiados, así como los proyectos de vida futuros. En relación a las preferencias lingüísticas, encontramos dos tendencias: quien quiere aprender más de una lengua extranjera (trece informantes de los veintitrés) y quién quiere aprender sólo el italiano (diez informantes). 
Las lenguas mencionadas hacen referencias casi en su totalidad a lenguas europeas. Con la excepción de un estudiante egipcio que, al no profundizar en los estudios en su tierra, declara querer aprender mejor su lengua materna. Las lenguas que la mayoría de ellos eligen para un posible futuro curso son el inglés, el francés y el alemán. Estas lenguas han sido elegidas por ser las lenguas que facilitan la movilidad entre países y es fundamental conocerlas para quien se plantea vivir en otro país. A continuación, recogemos algunos testimonios que lo ponen de manifiesto "No es posible vivir sin ellas porque son las lenguas del mundo hoy" (R12, Mauritania); "El francés y el inglés son habladas en todo el mundo" (R13, Niger); "Es la lengua universal" (R4, Costa de Marfil); "Me permitirán de circular fácilmente en el mundo" (R14, Guinea); "Para trabajar, si hablas inglés, puedes ir donde quieres" (R15, Gambia).

Holanda parece ser uno de los destinos ideales de los estudiantes nigerianos, algunos de ellos han expresado la voluntad de aprender la lengua holandesa además del deseo de viajar a dicho país en un futuro. No obstante, en muchas ocasiones el colectivo de refugiados declara no saber que le reserva el futuro y que todo depende de dónde encuentren trabajo. Por lo que se refiere al italiano, debe ser aprendido necesariamente porque no hay posibilidad de utilizar una LF para comunicarse con la población local. Así se pone de manifiesto en las entrevistas y cuestionarios realizados: "Necesito aprender italiano para ser capaz de comunicar con los otros y comprendernos bien, si no hablo italiano no puedo hablar con nadie... ¿Por qué es así aquí? Nadie habla inglés. ¿Por qué? Si yo quiero decir algo a una persona en la calle, no puedo, tengo que hablar en italiano. Esto es malo.” (R7, Gambia).

En cambio, para otros el aprender italiano es natural: "Porque estoy viviendo en Italia" (R11, Guinea Bissau). También no faltan los que ven Italia como la tierra donde establecerse y formar una familia $y$ muestran voluntad de integrarse en este país: "Quiero quedarme en Italia, tener un trabajo y una familia y quiero aprender más sobre Italia; sobre leer y escribir y leer las noticias." (R16, Sierra Leona). Opinan de este modo los que declaran preferir la lengua italiana a la lengua nativa, es el caso de cinco refugiados, mientras que los dieciocho restantes declaran preferir la lengua materna. En este caso el tiempo de permanencia en Italia no es un factor determinante en la elección ya 
que en ambos casos los informantes llevan en Italia el mismo tiempo; parece más una elección personal no ligada a una variable en particular.

\section{Preferencias lingüísticas de los inmigrantes}

Las preferencias lingüísticas del colectivo de inmigrantes parecen diferir de las de los refugiados en cuanto a la consideración de la lengua italiana como lengua principal en las preferencias de los estudiantes. De hecho, la mayoría de los inmigrantes entrevistados considera la lengua italiana como aquella necesaria para vivir y siete de los diez aprendices declaran querer aprender solo italiano. Entre los tres restantes, dos quieren aprender inglés y uno quiere aprender español, además de italiano. Aunque se manifiesta curiosidad o necesidad por mejorar el inglés (considerada ésta una lengua que debería aprenderse por cualquier individuo) es la lengua italiana a la que se le concede mayor relevancia. Por otro lado, algunos inmigrantes casados con italianos consideran la lengua italiana al mismo nivel que la lengua nativa, concretamente cinco de los diez inmigrantes consideran las dos lenguas al mismo nivel, sin preferencias.

Estas preferencias están motivadas por el hecho que los inmigrantes se han establecido en Italia con su familia y planean quedarse de manera estable. Lo que sorprende es que la preferencia por el italiano es también mantenida por quien está en Italia hace poco y eso parece estar motivado por tener familia y trabajo en Italia, lo que significa para ellos que su futuro está en Italia. Similar es el sentimiento de quien vive en Italia porque está casado con un italiano. Para ellos, aunque su nivel de conocimiento del italiano no es muy alto, utilizan esta lengua para comunicarse en el día a día y por eso la reconocen como lengua propia.

\section{Conclusiones}

El proceso migratorio conlleva al aprendizaje de las lenguas de manera espontánea, llevando al migrante a manejar varias lenguas en niveles diferentes (Blommaert y Backus, 2013; Franceschini, 2006). Además de este tipo de aprendizaje realizado de manera espontánea y "voluntaria", el proceso migratorio está conectado también con un aprendizaje obligado, ligado a las políticas migratorias de los países europeos que lo establece como requisito de acceso y permanencia en el país (Pulinx, Van Avermaet \& Extramiana, 2014). En relación con el aprendizaje de nuevas lenguas durante el recorrido migratorio y la utilización del 
propio repertorio lingüístico, refugiados e inmigrantes se enfrentan a necesidades y preferencias lingüísticas particulares, lo que ha sido objeto de interés de esta investigación.

Al analizar los usos lingüísticos de inmigrantes y refugiados, se ha puesto de manifiesto que los dos colectivos se diferencian por la posibilidad de elegir qué lengua hablar, tanto en el tiempo libre como en casa. Si bien, por un lado, los inmigrantes eligen las lenguas para comunicarse en las dos situaciones, en el caso de los refugiados dicha elección depende de otros factores. Al respecto la posibilidad de hablar su lengua nativa depende directamente de la casualidad de vivir con un connacional o con alguien de su misma etnia en la casa de acogida. Así pues los refugiados utilizan muy a menudo lenguas vehiculares en las dos situaciones mencionadas (tiempo libre y hogar), mientras que los inmigrantes emplean la lengua de la familia, sea esta la lengua nativa y/o la lengua italiana.

Respecto al aprendizaje de lenguas extranjeras, los refugiados están más dispuestos a aprender otras lenguas europeas, debido en general a la eventualidad de vivir en otro país en el futuro. Al contrario, los inmigrantes manifiestan interés principalmente por el italiano y en menor proporción por aprender otras lenguas extranjeras.

Parte de este estudio pone el acento en la competencia plurilingüe de los aprendices del estudio: la casi totalidad de los estudiantes (veintisiete de treinta y tres informantes) habla una lengua vehicular y además poseen una amplia competencia comunicativa que les permiten hablar con compañeros de otras nacionalidades. También la comunicación entre el estudiante y el docente o trabajadores de los centros de atención o acogida está casi siempre garantizada por la utilización de lenguas vehiculares. Finalmente, a veces se dan situaciones asimétricas en las cuales el aprendiz posee una competencia comunicativa más elevada que la del docente, pues son conocedores de varias lenguas.

\section{Bibliografía}

Alvarez, C. (2008). La etnografía como modelo de investigación en educación. Gazeta de Antropología, 24 (1), 1-15. 
Blommaert, J. y Backus, A. (2013). Superdiverse repertoires and the individual. En I. Saint-Georgee y J.J. Weber (eds), Multilingualism and multimodality, (pp. 11-32). Rotterdam: SensePublishers.

Campesi, G. (2011). La detenzione amministrativa degli stranieri: storia, diritto, politica. Democrazia e diritto, 3-4, 177-225.

Catarci, M. (2014). Considerazioni critiche sulla nozione di integrazione di migranti e rifugiati, REMHU, 43, 71-84.

Consejo de Europa (2002). Marco común de referencia para las lenguas: aprendizaje, enseñanza, evaluación. Ministerio de Educación, Cultura, Deporte, Instituto Cervantes y Editorial Anaya.

Franceschini, R. (2006). Unfocussed Language Acquisition? The Presentation of Linguistic Situations in Biographical Narration. Historical Social Research, 31 (3), 29-49.

Krumm, H-J. y Plutzar, V. (2008). Tailoring language provision and requirements to the needs and capacities of adult migrants. Thematic Study V. Council of Europe, 1-14. Strasbourg, Council of Europe.

Landone, E. (2004). Plurilinguismo y pluriculturalismo en el Portfolio Europeo de las Lenguas. Mots Palabras Words, 5, 35-55. Locchi, M. C. (2012). L'accordo di integrazione tra lo stato e lo straniero. (Art. 4-Bis T.U. sull'Immigrazione N. 286/98 alla luce dell'analisi comparata e della critica al modello europeo di "integrazione forzata". Associazione italiana dei costituzionalisti, 1.

Pinson, H. y Arnot, M. (2007). Sociology of education and the wasteland of refugee education research. British Journal of Sociology of Education, 28(3), 399-407.

Pulinx, R., Van Avermaet, P. y Extramiana, C. (2014). Linguistic integration of adult migrants: Policy and practice. Final report on the 3rd Council of Europe Survey. Strasbourg: Council of Europe. 


\title{
Discurso del profesorado sobre alumnado extranjero y escolares con necesidades educativas especiales en la escuela italiana ${ }^{89}$
}

\author{
Alessandra Cama \\ Instituto de Migraciones, Universidad de Granada, España
}

\section{Resumen:}

El trabajo que presentamos forma parte de una tesis doctoral que pretende investigar la presencia de "escolares de nacionalidad extranjera" en el alumnado con "necesidades educativas especiales" y su eventual sobrerrepresentación en el conjunto del sistema educativo italiano. Como primer paso empezamos aclarando quiénes son los escolares que se etiquetan de "extranjeros" y qué se entiende por necesidad educativa especial analizando la normativa italiana sobre la adscripción de los escolares a esa categoría. A continuación, hacemos dialogar los textos escritos y los puntos de vista y representaciones de un grupo de profesionales de la escuela, escuchados durante nuestro trabajo de campo en diversos centros escolares de la ciudad de Mesina.

\footnotetext{
${ }^{8} \mathrm{El}$ trabajo que se presenta forma parte de una tesis doctoral en curso, que se está realizando en el Programa de Doctorado en Estudios Migratorios de la Universidad de Granada, bajo la dirección del Prof. F. Javier García Castaño. Queremos agradecer al Ministerio de la Instrucción Pública italiano la concesión de una licencia por estudios para el desarrollo de esa tesis doctoral. ${ }^{9}$ En todo el texto de la comunicación la traducción al español es mía.
} 
Finalmente, presentamos algunas reflexiones sobre la utilidad de usar esta "etiqueta", como forma de gestionar la diversidad.

Palabras clave: escolares extranjeros, Necesidades Educativas Especiales (NEE), diversidad, normativa, Italia.

\section{Introducción}

T A ESCUELA, espejo de la sociedad, está intrínsecamente 1 caracterizada por lo plural, por una diversidad que quizá se percibe más por la presencia creciente en las aulas de niños y niñas con una historia, directa o familiar, de migración, por recibir, cada vez más, a escolares de diferentes procedencias, cuyo país de nacimiento es distinto del de acogida o cuyos padres nacieron en un país diferente de aquel donde residen.

Según el último informe de la Fundación ISMU (2014/2015), realizado en colaboración con el Ministerio de Educación italiano, en Italia, las inscripciones del alumnado de nacionalidad extranjera en el periodo 2001/02-2014/15 se han cuadruplicado. En efecto, se ha pasado de los 196.414 escolares del curso 2001/02 (2,2\% de la población escolar global) a los 814.187 del curso 2014/15 (9,2\% del total).

Una tasa de crecimiento de ese tipo, junto a la complejidad del fenómeno, llevaron al Ministerio de Educación italiano a adoptar en 2014 unas nuevas ${ }^{10}$ Linee guida per l'accoglienza e l'integrazione degli alunni stranieri" ${ }^{11}$. Se trata de un documento que se presenta como "un instrumento de trabajo para directores, profesores, padres, agentes de las asociaciones [...] para reconsiderar y renovar la acción didáctica en beneficio de todos". Dicho de otro modo, ante el constante aumento de estos "nuevos escolares", la escuela habla de acogida y de integración, quiere ser "de todos".

El uso de la expresión "integración" remite inmediatamente a otro ámbito educativo, el de la educación especial, en el que se lleva usando ya desde hace más de treinta años y, más recientemente, al de las

\footnotetext{
${ }^{10}$ Nuevas porque las primeras Linee guida per l'accoglienza e l'integrazione degli alunni stranieri habían sido adoptadas en 2006, casi diez años antes.

${ }^{11}$ Directrices para la acogida y la integración de los escolares extranjeros.
} 
llamadas Necesidades Educativas Especiales ${ }^{12}$ (NEE), que incluyen entre sus sub-categorías precisamente a los escolares extranjeros, o bien con "dificultades causadas por el hecho de no conocer la cultura y la lengua italiana por ser pertenecientes a culturas diferentes" 13 . Ahora bien, si es cierto que para relacionarse en un grupo es muy útil conocer la lengua que se usa y sus formas y estrategias de relación, no podemos dejar de cuestionarnos sobre lo oportuno que es incluir, en nombre de la integración o de la inclusión, a personas que desconocen tal lengua y tales formas de relación en el mismo grupo en que se incluyen a quien tiene algún tipo de discapacidad funcional o trastorno del desarrollo. Asimismo, el discurso normativo aparece ambiguo y no pocas veces retórico y termina confundiendo a los mismos profesionales que tendrían que llevarlo a la práctica.

En el presente texto, nos centraremos en la posición que ocupan los llamados escolares extranjeros dentro de la categoría de las NEE en la actual "escuela inclusiva" italiana, para reflexionar sobre la necesidad de introducir esta forma de etiquetado como un recurso para poner orden y controlar esa diversidad que es solo del "otro". Para ello nos apoyaremos en una serie de entrevistas a un grupo de profesionales de la escuela realizadas durante nuestro trabajo de campo. Terminaremos con una serie de reflexiones sobre el uso de conceptos como diversidad, inmigrante o necesidades educativas especiales, en una escuela, reflejo de una sociedad que se define plural, pero que usa etiquetas que pueden terminar construyendo diferencias.

\footnotetext{
${ }^{12}$ Históricamente la noción de Necesidades Educativas Especiales aparece por primera vez en Inglaterra, en el célebre Informe Warnock de 1978. En este documento se indicaba que la situación dual del sistema educativo inglés, que catalogaba aproximadamente a un $2 \%$ de la población escolar como deficiente y por lo tanto atendida por el sistema de educación especial, mientras que el resto asistía a la escuela ordinaria era incorrecta. De hecho, Warnock consideraba que las causas de las dificultades para aprender no son únicamente deficiencias físicas, sensoriales o mentales, sino también escolares, sociales y de personalidad (Warnock, 1978: 37).

${ }^{13}$ En Italia se empieza a hablar de NEE solo a finales de 2012, o sea después de la adopción de la Directiva ministerial del 27 de diciembre, Strumenti di intervento per alunni con Bisogni Educativi Speciali e organizzazione territoriale per l'inclusione scolastica a la que siguió la Circular n. 8/2013, que apuntaba a ofrecer indicaciones operativas para identificar los escolares con NEE.
} 


\section{Metodología}

Como ya anunciábamos, para alcanzar el objetivo de nuestro trabajo e investigar la presencia de "escolares extranjeros" en el alumnado con "necesidades educativas especiales", nos ha parecido conveniente hacer dialogar los textos escritos y los puntos de vista y representaciones de un grupo de profesionales de la escuela. Por ello, hemos seguido una metodología etnográfica. Iniciamos nuestro trabajo de campo en septiembre de 2016, en Mesina, una ciudad de la zona oriental de Sicilia que cuenta con 649.824 habitantes en su último censo (2011) y, según los datos disponibles al 1 de enero de 2016, una población con nacionalidad extranjera que asciende a 28.136, correspondiente al 4,4\% de la población residente ${ }^{14}$.

En concreto, hemos contactado con profesionales de seis centros educativos, tanto de la escuela primaria como secundaria. Después de haber elaborado un protocolo de entrevista con preguntas generales sobre el tema de las NEE, la normativa y la forma en que se atiende a este colectivo de escolares, se han seleccionado personas con experiencia directa en el ámbito de la "necesidades educativas especiales", figuras responsables, profesores de educación especial, pero también maestras y profesoras curriculares que no tienen ninguna experiencia en educación especial. Se ha utilizado el llamado método de la "bola de nieve", o sea empezando por personas conocidas, docentes de la escuela primaria y secundaria. En total hemos desarrollado trece entrevistas a doce docentes. De ellas seis con responsabilidades directas sobre la llamada "educación especial" y seis no (son maestras y profesoras de Italiano, Matemáticas, Educación Física y Español); todas con más de quince años en su función docente. También hemos entrevistado a dos Directoras, a dos neuropsiquiatras infantiles y a dos pedagogas, éstos últimos por estar relacionados muy directamente con los procesos de diagnóstico de los escolares con NEE. Todas las entrevistas realizadas se han registrado electrónicamente (excepto las de las pedagogas que se han negado a

\footnotetext{
${ }^{14}$ Datos Istat, recuperados en http://www.tuttitalia.it/sicilia/provincia-dimessina/statistiche/cittadini-stranieri-2016/. En dicha ciudad se dispone de 299 escuelas de educación Primaria, 136 escuelas del primer ciclo de Secundaria, 68 Institutos Comprensivos; 64 Liceos; 48 Institutos Técnicos y 22 Institutos Profesionales.
} 
permitir la grabación). Luego se han transcrito y se ha ordenado el discurso a partir de las expresiones "escolares extranjeros" y "Necesidades Educativas Especiales".

\section{¿Quiénes son los escolares considerados inmigrantes o extranjeros?}

En Europa existen grandes diferencias a la hora de usar una terminología para identificar al alumnado denominado de "origen inmigrante". Algunos estudios usan el término "minoría étnica" o "grupos étnicos minoritarios" (UNESCO, 1994; Lindsay, Pather y Strand, 2006), mientras que otros emplean "migrantes" (OECD, 2007; Comisión Europea, 2008), "inmigrantes" (OECD, 2006), "alumnado bilingüe" o "minorías" (Consejo de Europa, 2006).

No cabe duda de que "llamar inmigrantes a personas asentadas en un territorio resulta cuanto menos inexacto, pues supone definir su condición social a partir de una acción, la de inmigrar, que puede haber sucedido hace tiempo o no haber sucedido" (Castilla Segura, 2018: 26), y, que, de todas formas, en el caso de los escolares, no se puede heredar. Quizá es por esto que, al menos en ámbito educativo, se nota un mayor uso de la expresión "extranjero".

Con todo, autores como Cohen (2003), García Borrego (2008) y Simon (1998) han reflexionado sobre la importancia de indicar con claridad de qué se está hablando cuando se emplea la expresión "alumnado de origen extranjero". ¿Se está hablando de la nacionalidad del escolar, de su procedencia? $O$, realmente, de lo que se habla es de que la lengua que éste aporta a la escuela no es convalidable con las "lenguas oficiales" que circulan por ella.

Como afirma Goussot (2010), habría que hablar de escolares hijos de migrantes, ya que no todos los escolares de origen extranjero son inmigrantes, o sea la mayoría de ellos no vivieron la experiencia de la migración porque nacieron en Italia. Tampoco es apropiado hablar de alumnado extranjero, ya que en muchos casos se trata de niños y niñas que de hecho son italianos y solo son hijos de padres de origen no italiano; además está el caso de los hijos de parejas mixtas, donde sólo uno de los padres es italiano. De hecho, según Caldin (2012), la acepción "menor extranjero" es muy difusa y no llega a expresar lo poliédrica que es la situación, máxime cuando bajo esta etiqueta 
englobamos a menores no acompañados, reagrupados, nacidos en Italia de padres ${ }^{15}$ migrantes, entre muchas otras situaciones concretas.

\section{¿A quiénes se refieren los textos ministeriales?}

Con todo esto, a pesar del carácter multifacético de esta realidad, los documentos del Ministerio de Educación italiano usan principalmente la expresión "alumnado extranjero"16, aunque, también es cierto que en un mismo texto, como por ejemplo la Circular Ministerial n. 301 del 8/9/1989, Inserimento degli alunni stranieri nella scuola dell'obbligo 17 , se pueden encontrar múltiples expresiones para referirse siempre al mismo colectivo: "Jóvenes inmigrados", "menores extranjeros", "jóvenes procedentes del extranjero", "hijos de trabajadores migrantes", "sujetos de reciente inmigración", "alumnos inmigrados", "alumnos pertenecientes a etnias diferentes".

Pero, veamos qué aparece en el documento más reciente, esto es, en las ya citadas nuevas Linee guida. En el apartado titulado Quiénes son los escolares de origen extranjero, leemos una primera distinción entre los "escolares de ciudadanía no italiana nacidos en Italia" y los "recién llegados" o "escolares de reciente inmigración" que representarían, en palabras del Ministerio, "los dos extremos opuestos del «planeta» escolares extranjeros". La cuestión subyacente y determinante para pertenecer a este grupo parece ser lingüística, o sea si dominan o no la lengua vehicular de la institución escolar. Sin embargo, a continuación, se admite que "simultáneamente, la experiencia de estos años ha puesto de relieve la necesidad de prestar atención a nuevos tipos de estudiantes con problemáticas interculturales y de integración, a pesar de contar con la nacionalidad italiana" (Linee guida per l'accoglienza e l'integrazione degli alunni stranieri: 5). Por ello el texto normativo usa

\footnotetext{
15 Aquí y en todo el texto el término "padres" engloba a padres y madres.

${ }^{16}$ De manera resumida citamos las siguientes normas: La CM n. 301 del 8/9/1989, Inserimento degli alunni stranieri nella scuola dell'obbligo. Promozione e coordinamento delle iniziative per l'esercizio del diritto allo studio; la CM n. 205 del 26/07/1990 La scuola dell'obbligo e gli alunni stranieri: l'educazione interculturale; la CM n.122 del 28/04/1992 Pronuncia del Consiglio Nazionale della P.I. sulla educazione interculturale nella scuola; la CM n. 73 del 2/3/1994 Proposte e iniziative per l'educazione interculturale; o la CM n. 24, del 1/3/2006 Linee guida per l'accoglienza e l'integrazione degli alunni stranieri.

${ }^{17}$ Inserción de los escolares extranjeros en la enseñanza obligatoria.
} 
una serie de expresiones para detallar situaciones particulares que ampliarían el marco global de los grupos a los que hacen referencia las citadas Linee guida: "escolares de nacionalidad no italiana"; "escolares con entorno familiar no italófono"; "menores no acompañados"; "escolares hijos de parejas mixtas"; "escolares llegados por adopción internacional"; "escolares romaníes, sintis e itinerantes". Resulta evidente que hablar de escolares inmigrantes es incorrecto, igual que no parece nada acertada la etiqueta de "extranjeros", al representar a menudo a sujetos que nacieron en el territorio italiano y están escolarizados en el sistema educativo italiano desde la escuela infantil, por lo que se sienten "autóctonos" de derecho.

\section{¿A quiénes se refiere el profesorado entrevistado?}

A partir de una serie de entrevistas semiestructuradas, hemos podido hacer una primera descripción de los tipos de discursos que se producen en el ámbito escolar sobre el concepto de escolares extranjeros. El profesorado entrevistado parece no considerar realmente como extranjeros a los escolares nacidos en Italia y destacan la distinción ligada al lugar de nacimiento. Algunos docentes, como María $^{18}$, maestra de educación especial y responsable para la discapacidad de un centro escolar con una importante presencia de escolares de origen extranjero, usa la expresión "de primera generación, o sea los que nacieron fuera de aquî" en contraposición con los que nacieron en Italia, como si el hecho de haber nacido en nuestro país los hiciera menos extranjeros. De la misma opinión es Simona, profesora de italiano de secundaria que dice: "Yo por ejemplo en una clase tengo a 5 chicos filipinos, pero nacieron aquí. Por lo tanto, no hay esas dificultades que se presentan con quien está de paso, como un menor no acompañado o que lleva poco tiempo en Italia”.

\footnotetext{
${ }^{18}$ En todos los casos los nombres del profesorado utilizados son ficticios para mantener el anonimato de los profesionales con los que hemos trabajado en nuestro trabajo de campo.

${ }^{19}$ Aunque los textos de las transcripciones de las entrevistas están en italiano, hemos decidido poner aquí la traducción al español, para facilitar el análisis del discurso y evitar interrumpir la lectura, sobre todo teniendo en cuenta que la Comunicación ha sido elaborada para ser presentada en la Universidad de Granada.
} 
La misma representación la constatamos en Patricia, profesora de matemáticas en un Instituto Técnico, quien, a la pregunta "AActualmente tienes a muchos escolares extranjeros?, contesta: "Tengo a dos en segundo, (...) y en quinto tengo a una, sí, pero ya..., o sea ¿extranjera?, pienso que ya sus padres... la chica nació aquí, habla perfectamente italiano".

Estos datos ilustran cómo el profesorado asocia de alguna manera la etiqueta de "extranjero" a no dominar el italiano o a otras dificultades de integración, pero no asocia de forma automática el término a la nacionalidad.

\section{¿Quiénes son los sujetos con Necesidades Educativas Especiales en la escuela?}

En el escenario internacional existen importantes diferencias entre los sistemas educativos, sobre todo y en particular, en lo que atañe a la educación de personas con "discapacidad" y/o con "necesidades educativas especiales". El propio término de educación especial o de "necesidades educativas especiales" responde a realidades muy diferentes según los países. Cubre una variedad de alumnado que en algunos países corresponde exclusivamente a alumnos con discapacidad y en otros países a cualquier escolar que presente alguna necesidad educativa por razones tales como la pertenencia a minorías étnicas, pobreza, etc.

Para una correcta "delimitación" de los alumnos que se incluyen en estas categorías se debe acudir, en primer lugar, a la normativa de cada país. Como nuestro trabajo se centra en el caso italiano, nos detendremos brevemente en la norma italiana que nos ayuda a definir quiénes son los sujetos con "necesidades educativas especiales" en ese contexto territorial.

\section{Normativa italiana que "delimita” a los escolares con NEE}

En la escuela italiana se empieza a hablar de $\mathrm{NEE}^{20}$ a partir de finales de 2012, es decir, después de la adopción de la Directiva ministerial del

\footnotetext{
${ }^{20}$ Históricamente la noción de Necesidades Educativas Especiales aparece por primera vez en Inglaterra, en el Informe Warnock de 1978. En este documento se indicaba que la situación dual del sistema educativo inglés, que catalogaba aproximadamente a un $2 \%$ de la población escolar como deficiente y por lo
} 
27 de diciembre de 2012, Strumenti di intervento per alunni con Bisogni Educativi Speciali e organizzazione territoriale per l'inclusione scolastica.

La citada Directiva incluye en las NEE tres grandes sub-categorías:

la discapacidad, certificada en virtud del art. 3, apartados 1 o 3 (gravedad) de la Ley 104/92, que da derecho a la asignación de un profesor especial;

los Trastornos Específicos del Desarrollo (TED), diagnosticados en virtud del art. 3 de la Ley 170/2010, que, según la Directiva, si no son certificados o no pueden ser certificados conforme a la ley 104/92, no dan derecho al profesor especial y comprenden, además de los trastornos específicos del aprendizaje, los trastornos por déficit del lenguaje, de las habilidades no verbales, de la coordinación motora, de la atención e hiperactividad y el funcionamiento intelectual limitado (FIL), que se considera un caso límite entre la discapacidad y el trastorno específico; la desventaja socio-económica, lingüística, cultural: la Directiva establece que la identificación de estas tipologías de NEE debe corresponder a los Consejos escolares.

A esta Directiva siguió la Circular n.8/2013 del Ministerio de Educación, con el fin de ofrecer indicaciones operativas, para identificar al alumnado con NEE.

En su introducción se lee:

La Directiva redefine y completa la tradicional aproximación a la integración escolar, basada en la certificación de la discapacidad, extendiendo el campo de intervención y de responsabilidad de toda la comunidad educativa al entero ámbito de las Necesidades Educativas Especiales (NEE), que incluye: “desventaja social y cultural, trastornos específicos del aprendizaje y/o trastornos específicos del desarrollo, dificultades debidas al no conocimiento de la cultura y de la lengua italiana por ser de culturas diferentes".

tanto atendida por el sistema de educación especial, mientras que el resto asistía a la escuela ordinaria era incorrecta. De hecho, Warnock consideraba que las causas de las dificultades para aprender no son únicamente deficiencias físicas, sensoriales o mentales, sino también escolares, sociales y de personalidad (Warnock, 1978: 37). 
Es de gran interés para nuestro estudio el epígrafe sobre "el área de la desventaja socio-económica, lingüística y cultural". Es en ésta donde se especifica y justifica la presencia, dentro del alumnado "con necesidades especiales", de la población escolar de nacionalidad extranjera por no dominar la lengua italiana (alumnado de origen extranjero de reciente inmigración). En la Circular se puede leer:

Asimismo, se quiere llamar aún más la atención sobre aquella área de las NEE que interesa la desventaja socio-económica, lingüística, cultural. Al respecto, la Directiva recuerda que "cada escolar, de forma continuada o durante determinados periodos, puede manifestar Necesidades Educativas Especiales: o por razones físicas, biológicas, fisiológicas o también por motivos psicológicos, sociales, por los cuales hace falta que las escuelas ofrezcan una respuesta adecuada $y$ personalizada". (...) Para estos escolares y en particular para aquellos que experimentan dificultades como consecuencia de no conocer la lengua italiana -por ejemplo alumnos de origen extranjero de reciente inmigración y, especialmente, aquellos que han entrado en nuestro sistema escolar en el último año- es posible también poner en marcha itinerarios individualizados y personalizados, además de adoptar instrumentos compensatorios y medidas de dispensa (por ejemplo dispensar de leer en voz alta y de llevar a cabo actividades en las cuales la lectura es objeto de evaluación, escritura rápida al dictado, etc.), con las modalidades anteriormente mencionadas (Circular ministerial, n. 8 del 6 de marzo de 2013).

En conclusión, la normativa no "delimita", sino que lo pone todo en un mismo "saco": razones físicas, biológicas, fisiológicas, pero también motivos psicológicos, sociales, económicos o el hecho de ser de cultura diferente y no dominar el idioma vehicular del centro escolar.

\section{¿Y qué dice el profesorado aludiendo a esos escolares?}

Sobre "escolares extranjeros" y "necesidades educativas especiales", la primera evidencia que destacamos es que el hecho de no hablar la lengua vehicular de la escuela es un elemento determinante a la hora de establecer si un escolar de origen extranjero es también un escolar con NEE o no. Por ejemplo, tenemos el caso de Caterina, responsable para los escolares con NEE de un Instituto que incluye jardín de infancia, escuela primaria y primer ciclo de secundaria, y también referente para 
la Asociación Resabes (REte Scuole Alunni con Bisogni Educativi Speciali), que ofrece asesoramiento y formación a docentes, familias y profesionales, quien nos habla del caso de uno de sus alumnos, ruso, que, a pesar de no hablar el italiano, no fue considerado con NEE:

"No lo consideramos porque había asistido ya durante un año a nuestro jardín de infancia (...). Bueno, digamos, lo consideramos entre comillas un escolar con "desventaja" pero no lo declaramos ni elaboramos un $\mathrm{PDP}^{21} ;(\ldots)$. No lo consideramos porque, sabes, el primer año de primaria es difícil identificar a escolares NEE, o sea esperas, les das tiempo a los niños. Normalmente ya desde el segundo año los señalas, mejor dicho, a finales de segundo informas al equipo y les dices a la familia que el hijo debe someterse a visita".

Asimismo, hay profesionales que mantienen que, ya que todos los escolares presentan necesidades diferentes y especiales, en lugar de identificar esas necesidades especiales se necesitaría más bien introducir y hablar de una enseñanza educativa especial.

Ana, por ejemplo, profesora de educación especial y responsable para la inclusión de un centro escolar donde hay una presencia significativa de alumnado extranjero, sobre todo en la educación primaria, afirma que en la práctica todos los escolares podrían ser niños con NEE:

"Se ha creado esta mega-categoría de escolares, la categoría de las necesidades educativas especiales, necesidades educativas especiales que de alguna manera lo dicen todo y no dicen nada (...). Es necesario leer la necesidad educativa especial como la necesidad de que cualquier estudiante sea atendido, sea visto de manera personal".

Similar opinión mantiene Matilde, profesora de italiano en Secundaria en un Instituto donde hay una importante presencia de escolares de Filipinas, Sri Lanka y China, pero en el que no se suele asociar la nacionalidad extranjera con tener necesidades especiales:

" $\mathrm{Si}$ consideramos específicamente las necesidades educativas especiales, si realmente analizamos cada una de ellas, todos los escolares pueden serlo, todos necesitan atención, si ésta es la línea del Ministerio. Creo que, más allá de la normativa, siempre y en cualquier caso hemos atendido a un estudiante con necesidades particulares, que

${ }^{21}$ Se trata de un plan de trabajo personalizado. 
sé yo, porque está en una franja de edad difícil, compleja, tal vez porque, no sé, sus padres se han separado, o porque viven un momento particular de conflicto, por lo que siempre han sido escolares con NEE, sí, probablemente incluso nosotros lo fuimos, cuando íbamos a la escuela, y nadie nunca se dio cuenta ni se preocupó”.

Al respecto, Chiara, directora de un centro que incluye jardín de infancia, escuela primaria y primer ciclo de secundaria, muy sensible a la cuestión de la diversidad, afirma tener una opinión contra corriente en lo que atañe a la introducción de la expresión NEE:

"Yo le daré una respuesta que va contra corriente, porque asumo que las necesidades educativas especiales son las necesidades educativas de todos, ¿por qué no?, Usted también, yo también, del ser humano, y todos somos diferentes y es la escuela la que debe garantizar una individualización continua y constante de la enseñanza y, por lo tanto, de las modalidades de aprendizaje y socialización".

La observación y las entrevistas destacan que, en la mayoría de los casos, los consejos escolares no suelen englobar de forma automática en el colectivo de las NEE a todos los escolares que "no conocen la cultura y la lengua italiana por ser de culturas diferentes".

Además, en general, el profesorado se resiste a incluir al alumnado en ese colectivo, - salvo que no haya un diagnóstico que les obliga -, ya que hacerlo se traduce en una serie de trámites burocráticos e informes a redactar y presentar que dificultan y hacen más laboriosa su labor en el aula.

\section{Concluyendo: escolares extranjeros, Necesidades Educativas Especiales y construcción de diferencias}

La escuela, espejo de una sociedad que se organiza y establece formas y modos estandarizados de comportarse, parece querer introducir términos aparentemente inocuos, - como "necesidades especiales", sinónimo de "necesidades diferentes", - para afirmar la importancia de reconocer que somos todos diferentes. Se trata de un discurso políticamente correcto difícil de cuestionar. Sin embargo, hay mucha heterogeneidad bajo el epígrafe de diversidad. De hecho, si la diversidad es una característica, natural, connatural, positiva y enriquecedora, cabe preguntarse ¿por qué hace falta excluir a algunos "diversos" e incluirlos en itinerarios diferenciados? En palabras de 
Almeida, “...este paraguas de la diversidad nos provee de nombres lavados aparentemente menos violentos que protegen más a quien nombra que a quien es nombrado" (2010: 31). En realidad, según Teresa, una neuropsiquiatra infantil, Directora de un Centro de diagnóstico y tratamiento de NEE y trastornos del aprendizaje, que colabora con muchas escuelas en muchos proyectos, se necesitaría crear, en lugar de

"Una necesidad educativa especial, una enseñanza educativa especial. Habría que usar una metodología diferente, hecha precisamente por los docentes, un método diverso (...). Y el método debería ser esto, en mi opinión: cada uno debería estudiar como le dé la gana, siempre y cuando alcanza el objetivo. Y así, no se necesitaría especificar un diagnóstico u otro, una necesidad educativa en lugar de otra. No haría falta”.

Sin embargo, la normativa insiste en "adoptar instrumentos compensatorios y medidas de dispensa (por ejemplo, dispensar de leer en voz alta y de llevar a cabo actividades en las cuales la lectura es objeto de evaluación, escritura rápida al dictado, etc.)", quedándose en la lógica escolar según la cual lo más importante es medir resultados, una lógica que se funda en establecer distancias diferenciales, escalas o niveles. Así, en nombre de la diversidad, en realidad se crean diferencias y desigualdades, en una institución que proclama "el intercambio, el diálogo, el mutuo reconocimiento y enriquecimiento de las personas en el respeto de las diversas identidades y pertenencias y de la pluralidad de experiencias a menudo multidimensionales de cada uno, italiano y no" (Linee guida per l'accoglienza e l'integrazione degli alunni stranieri: $4)$.

A pesar de que existe un amplio consenso sobre las distorsiones que produce la categorización de alumnos, estos criterios categoriales están presentes en los informes que elaboran el profesorado, así como en los Planes Didácticos Personalizados que deben elaborar los centros. Parece evidente que el uso de estos criterios responde a procesos de gestión educativa y de control institucional, muy vinculados a la distribución de recursos en el caso de las NEE.

A pesar de todo, la escuela representa una oportunidad única para construir y consolidar vínculos fundados precisamente en la diversidad, 
pero hace falta revolucionar todo el sistema. No basta con cambiar la terminología, es necesario un cambio de paradigma. Lo explica bien Skliar, cuando afirma que estamos obsesionados por los diversos y habla de "un cambio paradigmático que aún no hemos hecho: una transformación ética que desplace la mirada sobre sujetos apuntados como diferentes, y pase a ser una mirada puesta en un nosotros, en aquello que pasa - pedagógicamente - entre nosotros" (Skliar, 2008: 15).

La escuela puede hacer que la experiencia educativa se convierta en una posibilidad de participación y crecimiento para la toda la comunidad, pero se necesitan principios y valores compartidos por todos los actores (Ostinelli, 2014). Es precisamente esto lo que manifiesta Caterina, que ya hemos citado, haciendo referencia a un episodio de aparente rechazo de un compañero extranjero por parte de una niña de unos 6 años que se puso a llorar porque no quería a ese niño recién llegado de Rumania: "¿qué deberíamos hacer nosotros? Educar, a nuestros escolares, al hecho de que ya la sociedad es multiétnica, multicultural, ayudarlos a que se abran a las diferentes experiencias. (...) Hace falta trabajar, pero no debe trabajar solo la escuela, en primer lugar, la familia".

Y además de valores compartidos, se necesitan, por último, políticas que no se preocupen solo por poner orden en la diversidad, sino que sean solidarias porque, en resumidas cuentas, "es la solidaridad que permite percibir la diferencia como una riqueza y no como una amenaza” (Dovigo, 2017:105).

\section{Bibliografía}

Almeida, M. (2010). Nuevas retóricas para viejas prácticas.

Repensando la idea de diversidad y su uso en la comprensión y abordaje de la discapacidad". Política y Sociedad, XLVII, 1: 2744.

Booth, T., y Ainscow, M. (2008). L'index per l'inclusione.

Promuovere l'apprendimento e la partecipazione nella scuola. Trento, Edizioni Erickson. 
Caldin, R. (2012). Alunni con disabilità, figli di migranti: approcci culturali, questioni educative, prospettive inclusive, Roma: Liguori Editore.

Cama, A. (2017a). Normativa italiana sobre la delimitación de escolares con necesidades educativas especiales y su relación con la población de nacionalidad extranjera. Comunicación presentada en el Seminario Doctoral de Investigación Perspectivas Jurídicas y Políticas en los Estudios Migratorios (Palermo, 14-16 de febrero de 2017).

Cama, A. (2017b). Integración versus inclusión: la escuela se llena de inclusividad. Comunicación presentada en el Seminario Doctoral de Investigación Perspectivas Psicológicas y Educativas en los Estudios Migratorios (Palermo, 28-30 de marzo de 2017).

Cama, A. (2017c). La sobrerrepresentación de escolares de nacionalidad extranjera en el grupo de alumnado con necesidades educativas especiales. Comunicación presentada en el Seminario Doctoral de Investigación Perspectivas Culturales en los Estudios Migratorios (Palermo, 9-11 de mayo de 2017).

Castilla Segura, J. (2018). Las Atal: una experiencia andaluza de incorporación del "alumnado inmigrante" considerado de "origen extranjero".

Cohen, A. (2003). Las categorías estadísticas de la inmigración: acotaciones a un debate francés. Eria, (60), 5-15.

Comisión Europea (2008). Libro Verde: Inmigración y movilidad. Retos y oportunidades para los sistemas educativos de la UE (423).

Consejo de Europa (2006). Recomendación Rec(2006)5 del Comité de Ministros a los Estados miembros sobre el Plan de acción del Consejo de Europa para la promoción de derechos y la plena participación de las personas con discapacidad en la sociedad: mejorar la calidad de vida de las personas con discapacidad en Europa 2006-2015.

Dovigo, F. (2017) Integrare e/o includere: l'esperienza italiana alla luce della letteratura internazionale CQIA RIVISTA, VII, 20: 100-108. 
Fundación ISMU-MIUR (2015). Alunni con cittadinanza non italiana. Tra difficoltà e successi. Rapporto nazionale A.s. 2013/2014. Milán: Fundación ISMU.

Fundación ISMU-MIUR (2016). Alunni con cittadinanza non italiana. La scuola multiculturale nei contesti locali. Rapporto nazionale A.s. 2014/2015. Milán: Fundación ISMU.

García Borrego, I. (2005). La construcción social de la inmigración: el papel de la universidad. En A. Pedreño Cánovas \& M. Hernández Pedreño (Eds.), La condición inmigrante.

Exploraciones e investigaciones desde la Región de Murcia (pp. 19-32). Murcia: Universidad de Murcia.

García Borrego, I. (2008). Herederos de la condición inmigrante: adolescentes y jóvenes en familias madrileñas de origen extranjero. Universidad Nacional de Educación a Distancia.

García Castaño, F. J. (2016). Terminologías y denominación de los "grupos minoritarios". Sobre la contribución de la ciencia a la construcción de la diferencia y la desigualdad. Ponencia invitada pronunciada en el V Congreso Internacional Multidisciplinar de Investigación Educativa (CIMIE 16): Investigación educativa con impacto social (Sevilla, 30 de junio a 1 de julio de 2016).

García Castaño, F. J. (2016). ¿Existen las personas que denominados "escolares inmigrantes extranjeros"? Ponencia invitada pronunciada en el Seminario Doctoral de Investigación Perspectivas Psicológicas y Educativas en los Estudios Migratorios (Palermo, 28-30 de marzo de 2017).

Goussot, A. (2010). Bambini stranieri con bisogni speciali: rappresentazione della disabilità dei figli da parte delle famiglie migranti e degli insegnanti. Ricerche di Pedagogia e didattica, 5(1), 271-296.

Lindsay, G., Pather, S., y Strand, S. (2006). Special Educational Needs and Ethnicity: Issues of Over- and Under-Representation. Nottingham, UK: Department for Education and Skills. Ministero dell'Istruzione, dell'Università e della Ricerca (1989), Inserimento degli alunni stranieri nella scuola dell'obbligo, Roma: MIUR.

Ministero dell'Istruzione, dell'Università e della Ricerca (2012). Strumenti di intervento per alunni con Bisogni Educativi 
Speciali e organizzazione territoriale per l'inclusione scolastica. Roma: MIUR.

Ministero dell'Istruzione, dell'Università e della Ricerca (2014). Linee guida per l'accoglienza e l'integrazione degli alunni stranieri. Roma, MIUR.

Ministero dell'Istruzione, dell’Università e della Ricerca (2015).

L'integrazione scolastica degli alunni con disabilità - a.s.

2014/2015. Roma: MIUR - Ufficio di Statistica.

Observatorio Europeo del Racismo y la Xenofobia. (2004).

Actividades del Observatorio Europeo del Racismo y la

Xenofobia: informe anual 2004-2005. Oficina de Publicaciones

Oficiales de las Comunidades Europeas.

Organización de las Naciones Unidas para la Educación, la Ciencia y

la Cultura (1994). La Declaración de Salamanca y el Marco de

Acción sobre Necesidades Educativas Especiales. Adoptada por

la Conferencia Mundial sobre Necesidades Educativas

Especiales: Acceso y Calidad. Salamanca: UNESCO.

Organización para la Cooperación y el Desarrollo Económico (2006).

Dónde tienen éxito los estudiantes migrantes. Un examen

comparativo de rendimiento y compromiso en PISA 2003.

París: OCDE

Organización para la Cooperación y el Desarrollo Económico (2007).

Grupos de riesgo: El caso especial de los migrantes y las minorías. En No más fracasos: diez pasos para la equidad en educación. París: OCDE.

Skliar, C. (2008). ¿Incluir las diferencias? Sobre un problema mal planteado y una realidad insoportable. Orientación y Sociedad, 8, 1-17.

Warnock, B. M. W. (1978). Meeting Special Educational Needs: A Brief Guide by Mrs. Mary Warnock to the Report of the Committee of Enquiry Into [the] Education of Handicapped Children and Young People. Londres: Stationery Office. 



\title{
E1 condicionante de la terminología en el caso de las migraciones
}

\author{
Amaia García-Azpuru \\ Profesora Agregada de la Escuela Universitaria de la \\ Cámara Bilbao University Business School (CámaraBilbaoUBS) \\ amaia.garcia@camarabilbaoubs.com
}

\section{Resumen}

Este trabajo analiza cómo en la sociedad vasca en particular sigue persistiendo desconocimiento terminológico en el ámbito de las migraciones y la influencia de los medios de comunicación sobre dicha cuestión, a pesar de que desde casi tres décadas, la llegada tanto de inmigrantes como extranjeros a España ha sido notoria, modificando la realidad social del país.

Con tal objetivo, se ha planteado una investigación empírica de carácter cuantitativo teniendo como base una encuesta realizada en tres centros educativos de la Comunidad Autónoma de Euskadi (CAE), seleccionados a través de un método no probabilístico, para los años 2009 y 2017; y al rastreo con base en los medios de comunicación de aquellas noticias que recogieran los términos inmigrante y extranjero; todo ello con el fin de comprobar si el uso que los medios hace de ellos es vinculante sobre el imaginario social y su posterior uso popular.

Los resultados extraídos muestran que sigue existiendo una falla entre lo que la población autóctona identifica como Inmigrante y Extranjero, y lo que ambos términos son en realidad. Además, se confirma que los medios de comunicación tienen mucho que ver en que el imaginario colectivo separe a inmigrantes y extranjeros por cuestiones diferentes a las reales, fomentando el uso erróneo de los términos, lo que a su vez 
puede derivar en consecuencias poco ventajosas de cara a conseguir una cohesión social.

Palabras clave: Inmigrante; extranjero; medios de comunicación; País Vasco; recursos económicos.

\section{Introducción}

A menudo se tiende a situar la contribución de la inmigración internacional en los países en el ámbito económico -tal y como recogen las tesis economicistas-, minusvalorando así otro tipo de causas y efectos. Sin embargo, desde la última década del siglo pasado, España ha visto cómo su nueva realidad social (la inmigración) está alterando desde la raíz el sustrato de la sociedad. Algo que, evidentemente también está sucediendo en la Comunidad Autónoma de Euskadi (CAE), aunque en este caso concreto la llegada de inmigración sucede de manera más lenta y tardía que en el resto de España.

Los flujos migratorios internacionales se convierten así en uno de los motores de las transformaciones sociales. Una gran fuerza que propicia cambios tanto en las sociedades de origen como en las de destino, contribuyendo al enriquecimiento de estas últimas no sólo en términos económicos sino también en términos sociales, al traer consigo una mayor diversidad y riqueza étnica y cultural; algo a lo que España no ha quedado ajena.

Desde la segunda mitad del siglo XIX la CAE ya se viene enfrentando a esas transformaciones sociales viviendo inicialmente la transición de momentos de emigración a otros de inmigración nacional -los años de la industrialización vasca, sobre todo para el caso de Vizcaya, pero también Guipúzcoa y Álava-, hasta llegar a una actualidad más reciente en la que la inmigración tiene un tinte más internacional. Inmigración que, en todos los casos, no sólo ha sido fundamental para el desarrollo de los territorios en su contribución económica sino también en la socio-demográfica, si bien los términos del pasado son diferentes a los del presente, radicando dichas diferencias en la propia naturaleza de los flujos. Naturaleza que presenta unas procedencias mucho más lejanas, más diversas y que muestra unas distancias sociales y culturales mayores a las de antaño. 
Más de dos décadas han pasado ya desde que en España se produjo un cambio social muy relevante y es que se pasó de ser un país eminentemente emigrante a ser un país clave en el destino de la inmigración internacional, colocándose como uno de los países que mayores flujos inmigratorios recibía en la primera década del siglo XXI. Es ahí cuando el país cambia su trayectoria histórica emigrante por una más inmigrante, hecho éste que tiende a indicar un desarrollo del país.

Sin embargo, lejos de ver ese cambio social como una parte fundamental y positiva para la mejora interna del país, a menudo se interpreta como un lastre que no hace sino interrumpir la cotidianeidad y la cohesión social. Surgen así recelos para ese "nuevo" colectivo que completa ahora nuestra sociedad y nuestra identidad. Recelos que, a menudo, surgen y se retroalimentan de la información que llega a través de los medios de comunicación y que se extiende y potencia aún más entre la propia sociedad, en nuestros entornos más cercanos.

Así pues, podría estar sucediendo que los discursos que vamos construyendo con respecto a la inmigración llegada a España tienen mucho más que ver con esos recelos que se van generando y retroalimentando que con la propia realidad. En otras palabras, estaríamos basando nuestras opiniones más en las percepciones de la realidad que en la realidad en sí misma. Hecho que no beneficia en absoluto la integración social, la convivencia ni la cohesión social.

Es más, el tratamiento que desde los medios de comunicación se hace del fenómeno migratorio cobra relevancia en el momento en que dicho fenómeno se instrumentaliza con el fin de conseguir ciertos objetivos políticos o servir de chivo expiatorio, útil para canalizar otro tipo de tensiones sociales y desviar debates sociales de mayor calado.

Los últimos años han sido muy prolijos en cuanto a la aparición del fenómeno migratorio en los medios de comunicación, coincidiendo además con que ésta se volvía desmesurada en los meses de verano, cuando la llegada de personas a España a través de las costas era más abundante ${ }^{22 .}$ De este modo, el ideario popular se va construyendo de

\footnotetext{
${ }^{22}$ Garcia Azpuru, Amaia (2016): "Influencia de los medios de comunicación en la sobrerrepresentación de los flujos migratorios en España”, en Herreros, J. y Mateos, C. (coord.), Del verbo al bit, Universidad de La Laguna, Tenerife, pp. 723-742.
} 
tal manera que, tanto los términos que se acabarán utilizando en su vocabulario habitual como la imagen que van forjándose sobre la inmigración, los pros y contras de su llegada, así como de su "utilidad", están totalmente vinculados y son fácilmente manipulables por intervenciones políticas, institucionales o periodísticas cuyo único propósito, a menudo, es encaminar la opinión pública hacia los objetivos prediseñados.

Una visión distorsionada de la realidad de los flujos migratorios internacionales que llegan al país redunda no sólo en términos de convivencia sino también en términos laborales, siendo más benévolos con unos colectivos y menos permisivos con otros, incluso perjudicándoles. Esta afirmación parece confirmarse cuando se observa el mercado laboral y la inserción más rápida o más dificultosa de determinadas procedencias extranjeras, posiblemente consecuencia de ese imaginario colectivo que posiciona a algunas personas por encima de otras, vinculando a las primeras con el concepto extranjero y a las segundas (las peor paradas) con el de inmigrante.

Intentando comprobar la pertinencia de dicha hipótesis, se realizó en 2009 una investigación ${ }^{23}$ donde se partía de la convicción de que la sociedad y el mercado laboral aceptan más fácilmente a aquél que consideran extranjero que al que consideran inmigrante; ya que en el País Vasco se discrimina negativamente al inmigrante y positivamente al extranjero. Y para cuya validación se analizó el conocimiento que una pequeña muestra de la sociedad vasca tenía en torno a esos conceptos clave: Inmigrante y Extranjero. Ambos términos ambos utilizados de forma cotidiana tanto por la población como por los medios de comunicación. El objetivo era comprobar si esas dos palabras de uso habitual en el vocabulario de la sociedad estaban siendo bien utilizadas y mantenían su definición original o, por el contrario, se les había conferido connotaciones diferentes a las que el propio término refería y, en consecuencia, podrían estar siendo responsables del posicionamiento parcial de la sociedad en favor de unos y en contra de otros. Esta investigación que se retomó en 2017 con el fin de evaluar

\footnotetext{
${ }^{23}$ Garcia Azpuru, Amaia (2009): Algunas percepciones sobre la funcionalidad económica de la inmigración en la sociedad vasca, tesina fin de máster Globalización y Desarrollo, HEGOA, Universidad del País Vasco/Euskal Herriko Unibertsitatea, Bilbao.
} 
la evolución de los resultados, que permitirían ver si la sociedad mantenía el mismo (des)conocimiento terminológico que presentaba en 2009, por el contrario, éste había cambiado. Dichos resultados se pasarán a detallar en posteriores apartados.

La investigación partía de la base de que los medios de comunicación tienen una gran responsabilidad en el posicionamiento de la sociedad en relación a los flujos migratorios, habiendo viciado las palabras inmigrante y extranjero con connotaciones negativas hacia esta primera y otras más positivas hacia la segunda, lo que ha revertido en una asimilación de los conceptos dentro de la sociedad que distan de su sentido original y que hacen que ésta (la sociedad receptora) actúe en consonancia a estos nuevos significados. Además, en ningún caso parece que se haya entrado a valorar si ha habido intencionalidad por parte de los medios en hacer esa diferenciación entre inmigrantes y extranjeros, o si, por el contrario, ha sido algo aleatorio que ha ido fluyendo paulatinamente.

\section{Dualización de la inmigración: Inmigrante Vs Extranjero}

Es habitual que los términos que se usan cotidianamente corran el riesgo de desvirtuarse en su contenido. Es algo que pasa en muchas ocasiones y el ámbito de las migraciones no queda ajeno a ello. La cuestión es que, cuando hablamos de migraciones no estamos hablando de algo etéreo sino de personas de carne y hueso y de ahí la importancia de hacer un uso correcto de las palabras, ya que hacerlo erróneamente puede alterar la percepción que la sociedad autóctona tiene de esas personas, a la par que puede perjudicar incluso la integración de las mismas en su lugar de llegada.

Es este punto el que nos llama a que analicemos más de cerca el tratamiento que se hace en la sociedad y en los medios de dos palabras, a priori, sencillas de comprender y utilizar que son: Inmigrante y Extranjero.

Antes de proseguir, se considera interesante hacer una pequeña aclaración sobre dichos términos, de cara a que el lector pueda interpretar mejor todo el documento y los resultados obtenidos en el estudio.

El término "migración" hace referencia a uno de los fenómenos sociales más importantes de nuestra era, formando parte del común 
acervo cultural y lingüístico. Sin embargo, no existe una definición operativa que nos permita diferenciar claramente qué movimientos de población pertenecen a esta categoría y cuáles, por el contrario, se escapan a ella.

Esta situación de indeterminación terminológica no es intranscendente, ya que puede tener efectos, en ocasiones, claramente negativos. En el caso que nos ocupa, de la ausencia de definición concisa de lo que puede ser considerado como migración se deriva, al menos, una consecuencia que, a su vez, genera efectos perversos sobre la propia realidad migratoria.

La falta de concreción terminológica deja paso al lenguaje común para que utilice y cree sus propias categorías y términos en función, muchas veces, de los estereotipos y prejuicios dominantes. Las migraciones son un claro ejemplo de ello. (Garcia-Azpuru, 2017:475)

Así, es fácil encontrar sociedades receptoras en las que se opera una dualización de los inmigrantes -o lo que es igual, se denomina con términos distintos lo que en realidad debería ser una única categoríasegún sea su lugar de origen, reservando para los procedentes de países desarrollados el término "extranjero", mientras que el de "inmigrante" lo aplican exclusivamente a aquellas personas extranjeras que proceden de países económicamente menos favorecidos. Asociando, además, cargas valorativas completamente opuestas entre sí, más favorable en el caso de los "extranjeros" y más desfavorable en el de los "inmigrantes". Todo ello conduce a una difusión y potenciación a través del lenguaje de la percepción de que hay diferentes "tipos" de inmigrantes, estableciendo una distancia cada vez mayor ente ambos grupos de extranjeros y, con ello, reforzando la mayor permisividad hacia unos y el mayor rechazo social hacia otros (Garcia-Azpuru, 2017:476). En la actualidad, es habitual evitar el uso del término "inmigrante" en las personas que se mueven dentro del mismo país por la carga peyorativa que ello conlleva.

Sin embargo, la diferencia entre inmigrante y extranjero no radica en su estatus económico-social sino en una cuestión jurídico-legal. Dicho en otras palabras, mientras que extranjera es la persona cuya nacionalidad es diferente a la nuestra; el inmigrante es aquél que reside en un lugar diferente al que ha nacido, independientemente de su 
nacionalidad e incluso del país de origen. Así nos podemos encontrar con distintas figuras que recogemos a continuación con el fin de aclarar un poco al lector sobre el tema:

- Inmigrante nacional: persona que no reside en el lugar que ha nacido, si bien su nacionalidad es la del país de residencia y ha nacido en él.

- Inmigrante nacional extranjero: persona que no reside en el lugar que ha nacido (aunque lo haya hecho en ese mismo país) y cuya nacionalidad no es la de ese país.

- Inmigrante internacional extranjero: persona que no reside en el país que ha nacido y cuya nacionalidad es diferente a la del país de residencia.

- Inmigrante internacional nacionalizado: persona que no reside en el país que ha nacido pero cuya nacionalidad es la del país de residencia.

En resumidas cuentas, a pesar de las figuras arriba expuestas, las sociedades receptoras en general, y la vasca en particular, diferencian entre inmigrantes y extranjeros de tal manera que esa diferenciación tiende a acarrear consecuencias sociales en el ámbito de la convivencia, la inserción y la adaptación del inmigrante dentro de esa nueva sociedad, poniéndoselo más difícil a él/ella de lo que le resulta a aquella persona que es catalogada como extranjero. Es más, no sólo se trata de una diferenciación social sino que el propio mercado de trabajo en destino también se hace eco de esa diferenciación y la amplifica cuando oferta sus puestos de trabajo, lo que retroalimenta las diferentes oportunidades y/o facilidades de incorporación a la nueva realidad de la persona recién llegada ${ }^{24}$.

\section{Metodología}

Esta investigación se ha realizado en dos fases con el fin de conseguir resultados que permitieran analizar no sólo el conocimiento que la sociedad vasca tiene de los términos "inmigrante" y "extranjero" en

\footnotetext{
${ }^{24}$ Léase Garcia Azpuru, Amaia (2017): Casualidad o causalidad de la afluencia inmigratoria en la Comunidad Autónoma de Euskadi, Tesis de Doctorado, HEGOA, Universidad del País Vasco/Euskal Herriko Unibertsitatea, Bilbao.
} 
esas dos fechas, sino la evolución de ese conocimiento, fruto del transcurso del tiempo y del trabajo de concienciación que desde distintos ámbitos (público-privado), como la campaña anti-rumores extendida por los tres territorios vascos, se ha venido llevando a cabo estos últimos años.

La primera fase de trabajo se llevó a cabo en junio de 2009, momento en el que da comienzo el estudio; y la segunda fase comprendió los años 2016-2017.

Se trata de una investigación empírica de carácter cuantitativo, basada en una encuesta realizada en tres centros educativos de la CAE, seleccionados a través de un método no probabilístico, dos de ellos repetidos en el tiempo y un tercero modificado por razones de operatividad. (Tabla 1.)

La encuesta se componía de cinco cuestiones relacionadas con los conceptos "inmigrante" y "extranjero", tal y como se recoge en el apartado Anexos.

Tabla 1. Centros seleccionados en 2009 y 2007 y número de encuestas anónimas realizadas

\begin{tabular}{|c|c|c|}
\hline CENTROS SELECCIONADOS & 2009 & 2017 \\
\hline Cámara Bilbao University Business School* & [54] & [112] \\
\hline $1^{\circ}$ carrera & 29 & 86 \\
\hline $3^{\circ}$ carrera & 25 & --- \\
\hline $4^{\circ}$ carrera & --- & 26 \\
\hline Escuela Pública Cervantes (Infantil y Primaria) & 21 & 18 \\
\hline UPV/EHU - $2^{\circ}$ Sociología & 9 & --- \\
\hline Colegio Inglés - $4^{\circ} \mathrm{ESO}$ & --- & 27 \\
\hline TOTAL ENCUESTAS & 84 & 157 \\
\hline
\end{tabular}

* La Cámara Bilbao University Business School (universidad privada) cambia su denominación a esta nueva en el curso 2017-2018, siendo anteriormente conocida como Escuela Universitaria de la Cámara de Comercio de Bilbao (EUCCB). El contenido de los grados también se mantiene prácticamente igual aunque su denominación varía pasando a llamarse actualmente: Grado en Gestión y Marketing Empresarial.

Fuente: elaboración propia. 
En 2017 se trabajó con una muestra de ciento cincuenta y siete personas, casi el doble de las que participaron en 2009 (84). La diferencia muestral es consecuencia de la premura con la que se tuvo que realizar la encuesta y explotación de los resultados en 2009, debido a los plazos de presentación de la tesina fin de máster en la que estaban englobados. Plazos que fueron modificados y reducidos en el último momento, no permitiendo una mejor planificación y/o recogida de datos.

A pesar de ello, esa diferencia en el tamaño muestral no impidió realizar una comparativa de los resultados obtenidos que permitieron aproximarnos a la realidad de la sociedad vasca y su evolución en los últimos ocho años. Años que, además, coinciden con el periodo de crisis económico-financiera que ha vivido el país -y que empieza a emerger entre 2009-2010 en el País Vasco- y con el comienzo de la recuperación.

Tabla 2. Medios de comunicación de los que se han extraído noticias relacionadas con las personas inmigrantes y extranjeras (desde 2002 hasta 2017) (número de noticias examinadas)

INMIGRANTE EXTRANJERO

\begin{tabular}{lrr}
\cline { 2 - 3 } www.abc.es & 358 & 92 \\
www.elcorreo.com & 624 & 411 \\
www.elmundo.es & 525 & 254 \\
www.elpais.com & 410 & 362 \\
www.expansion.com & 75 & 541 \\
www.huffingtonpost.es & 141 & 94 \\
www.lavanguardia.com & 263 & 178 \\
www.antena3.com & 55 & 44 \\
www.cuatro.com & 26 & 14 \\
www.eitb.eus & 65 & 78 \\
www.lasexta.com & 88 & 69 \\
www.rtve.es & 74 & 41 \\
www.telecinco.es & 68 & 47 \\
\hline TOTAL NOTICIAS & $\mathbf{2 . 7 7 2}$ & $\mathbf{2 . 2 2 5}$ \\
\hline
\end{tabular}

Nota: el número de noticias examinadas no implica que en dichos medios no se hayan producido más relativas a los términos objeto de nuestro estudio, sino que son las que se recogieron como muestra.

Fuente: elaboración propia. 
En paralelo a la encuesta entre 2016 y 2017 se realizó un rastreo con base en los medios de comunicación en general. Se pretendía analizar aquellas noticias en las que aparecieran los dos conceptos que venimos mencionando para ver si estos venían asociados a características específicas (unas asociadas al término "inmigrante" y otras al término "extranjero") o si, por el contrario, ambos términos eran utilizados indistintamente de cuál fuera el contenido de la noticia o las características asociadas a él. Con este barrido de medios se quería verificar si el tratamiento que de esos dos términos se hace en los medios es vinculante sobre el imaginario colectivo y su posterior uso popular. Lo prolijo de los datos analizados hace inviable la incorporación de todas las noticias en este artículo, si bien a continuación se muestran los medios con los que se ha trabajado (tabla 2.).

\section{Evidencias}

El análisis de los datos recogidos en el estudio de 2009-2017 permitió comprobar la pertinencia de considerar que la forma en la que los medios de comunicación hacen uso de los términos "inmigrante" y "extranjero" no sólo a menudo es errónea, sino que redunda en una contribución poco favorable para la migración en general, posicionando a ésta de manera inadecuada en el imaginario colectivo.

Así pues, de las encuestas pasadas en 2009 y 2017 se extraían una serie de conclusiones que, unidas al trabajo de rastreo de noticias en los medios, facilitaban la confirmación de que no sólo los medios de comunicación influyen en los estados de ánimo de la sociedad receptora de inmigración sino que también lo hace en el uso que posteriormente se hace de ambos términos -inmigrante y extranjero-, piedras angulares de la percepción y aceptación de las personas foráneas por parte de la población autóctona.

En los próximos subapartados se recoge el análisis de las encuestas, así como del rastreo de los medios de comunicación.

\section{Análisis de los resultados de las encuestas (2009 y 2017)}

En 2009 se comienza con la primera fase de la investigación. Se toma una muestra relativamente significativa de personas entre los que hay tanto alumnos/as universitarios de universidad privada y pública, como profesorado de infantil y primaria de la escuela pública del País 
Vasco, y se les pasa una encuesta de cinco preguntas - cuatro preguntas cerradas y una abierta- de las que se obtuvieron una serie de resultados que plasmaban una aproximación de la percepción social en el País Vasco en términos de migraciones internacionales.

En esta primera fase de la investigación (2009), los alumnos peruanos eran considerados inmigrantes en términos generales (49,7\%), siendo el profesorado de infantil y primaria así como el alumnado de $2^{\circ}$ de sociología los que así lo mencionan de forma más contundente; mientras que las personas alemanas se convertían en extranjeros para la mayoría de los/as encuestadas (61\%), siendo llamativo el hecho de que nadie de entre el alumnado de $3^{\circ}$ de carrera vincule a esos estudiantes con el término inmigrante, así como el hecho de que los/as de sociología son quienes, en contraposición al resto de respuestas obtenidas, con un $66,7 \%$ relacionan a los alemanes con la figura de inmigrante.

Por otra parte, al preguntar por los vecinos senegaleses, el 55,2\% de las personas encuestadas les conectaba con la imagen del inmigrante, siendo de nuevo el alumnado de sociología y el profesorado de la escuela pública vasca quienes apoyaban dichas respuestas de manera más significativa, con mayor intensidad en el caso del profesorado $(94,7 \%)$.

En 2009 los resultados obtenidos parecían avalar la hipótesis de partida en la que se determinaba que el término "inmigrante" era vinculado a determinados colectivos de menor poder adquisitivo, en situaciones de mayor vulnerabilidad y, a menudo, procedentes de países menos desarrollados. De este modo, ante la tercera pregunta de si los senegaleses eran inmigrantes o extranjeros, los resultados mostraban que había una opinión mucho más unánime de entender que éstos eran inmigrantes que para el caso de los estudiantes peruanos, a pesar de que el alumnado de tercero de carrera suavizaba un poco ese resultado tan unánime (en la pregunta tres) al aportar respuestas propias -opción c: "otros"- siendo, eso sí, todas ellas respuestas vinculadas al propio enunciado y, en muchas ocasiones, con calificativos peyorativos como: okupas, negritos, conflictivos,... Sin embargo, es en la cuarta pregunta donde se observa la mayor unanimidad de respuesta entre las personas encuestadas. El 82,5\% de las respuestas asociaba a las personas del top- 
manta con los inmigrantes siendo, una vez más, el colectivo de maestros/as de escuela quien lo hacía de forma más acusada (94,7\%).

De todo ello se concluía que, si bien la nacionalidad posiciona a la sociedad a la hora de utilizar la palabra "inmigrante" o "extranjero" (preguntas 1 y 2), el poder adquisitivo y, por ende, su medio de vida (su trabajo) lo determinan aún más si cabe (pregunta 4). Siendo asimismo importantes los condicionantes relativos a la etnia, la religió, la cultura,

En 2017 se da comienzo a la segunda fase del estudio. En este caso de vuelve a pasar la misma encuesta a cuatro colectivos, tres de ellos de las mismas características ${ }^{25}$ y sustituyendo al alumnado de segundo curso de sociología de la universidad pública por el de $4^{\circ} \mathrm{ESO}$ de un colegio privado.

Gráfico 1. Resultados a la pregunta 1. Si en tu clase hubiera tres alumnos peruanos los catalogarías como... (Años 2009 y 2017) (\%)

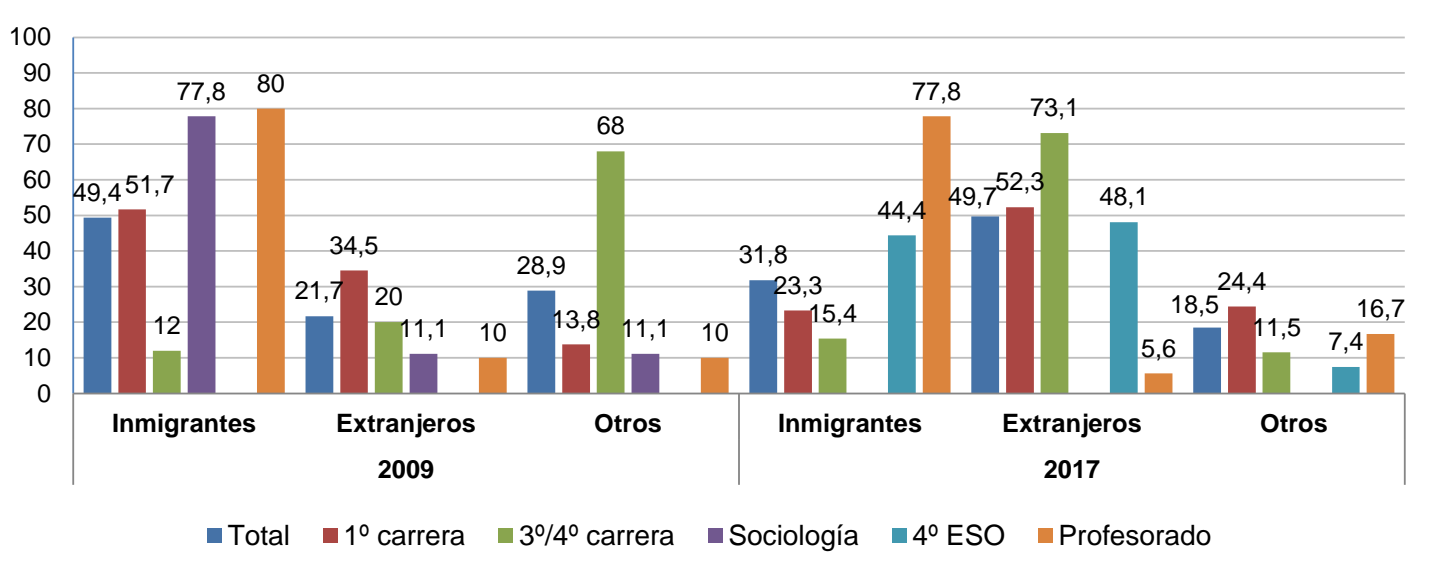

Fuente: elaboración propia.

En esta ocasión se obtenía, sobre todo, una diferencia entre los resultados obtenidos en 2009 y 2017 en la pregunta 1. En ella, las personas encuestadas en 2009 asociaban casi con un 50\% al estudiante peruano con la figura del inmigrante. Sin embargo, en 2017, ese mismo porcentaje lo hacía con la figura de extranjero. Asimismo, se observaban tres aspectos significativos en la comparativa de resultados: el primero era que tan sólo el grupo de profesores/as de infantil y

${ }^{25}$ Los alumnos de $3^{\circ}$ y $4^{\circ}$ de carrera podrían entenderse como un mismo grupo puesto que la conversión de la carrera de diplomatura a grado hizo que lo que en 2009 era el último curso en esa universidad (3º), en 2017 sea el $4^{\circ}$ curso. Así, en los gráficos aparecerán como un único grupo, aunque en las tablas se reflejarán los datos por separado. 
primaria parecía mantener bastante parejas sus respuestas en ambos años; el segundo mostraba la disparidad de respuesta entre el grupo saliente (sociología) y el entrante $\left(4^{\circ} \mathrm{ESO}\right)$, lo que tenía consecuencias sobre los resultados generales; y un tercer aspecto que mostraba un cambio en las respuestas del alumnado de primer año de carrera, quienes invertían sus resultados entre 2009 y 2017. (Gráfico.1.)

Para el resto de preguntas (preguntas 2, 3 y 4) si bien en 2009 y 2017 los resultados generales son similares, se observa un ligero incremento en el porcentaje de personas que asocian al estudiante alemán con el término extranjero (de 61\% a 65\%) y un pequeño descenso en lo relativo al senegalés inmigrante (de $59,8 \%$ a $51 \%$ ) y al peruano del topmanta inmigrante (de 82,5\% a 79,5\%). (Gráficos 2.-4.)

Gráfico 2. Resultados a la pregunta 2. Si en tu clase hubiera 2 alumnos alemanes los catalogarías como... (Años 2009 y 2017) (\%)

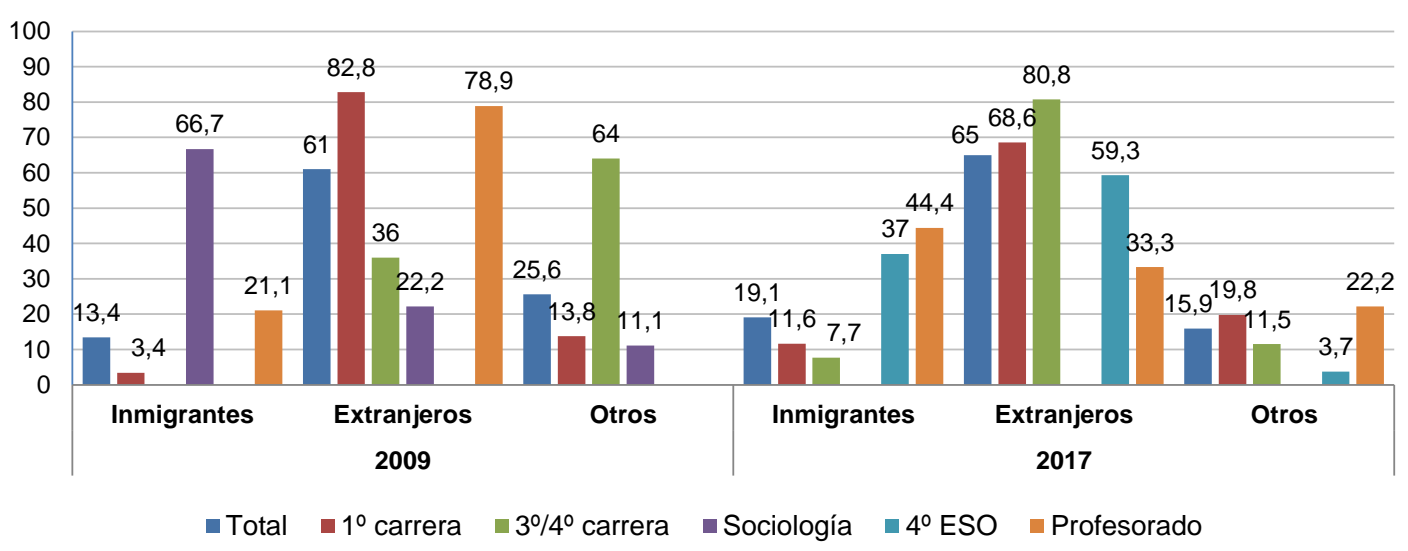

Fuente: elaboración propia.

Gráfico 3. Resultados a la pregunta 3. Si en el piso de al lado se van a vivir dos senegaleses, los catalogarías como... (Años 2009 y 2017) (\%)

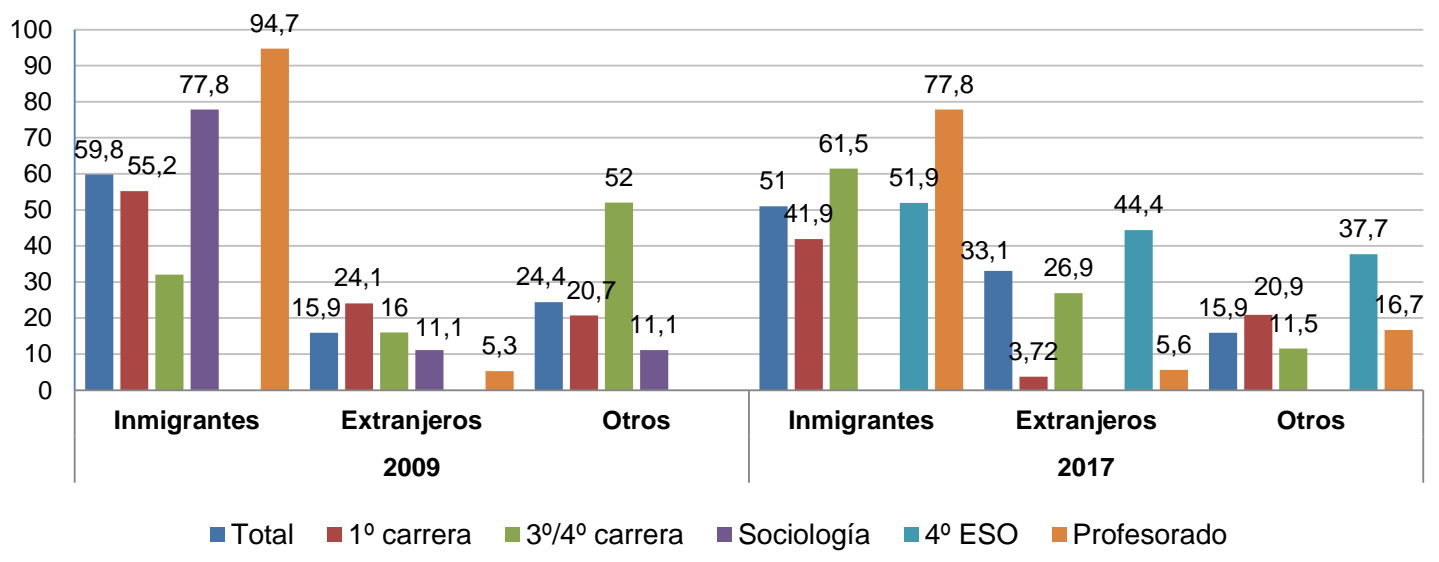

Fuente: elaboración propia. 
Gráfico 4. Resultados a la pregunta 4. Los peruanos que venden por la calle (top-manta), relojes, collares..., lo catalogarías como... (Años 2009 y 2017) (\%)

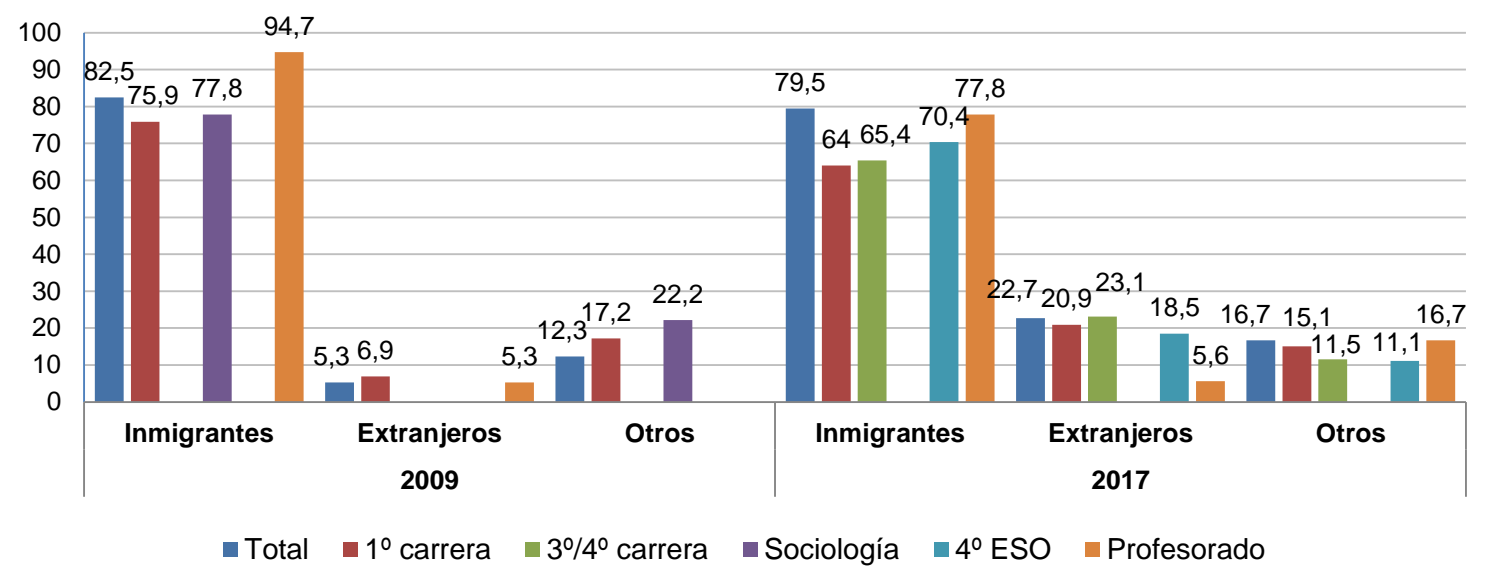

Fuente: elaboración propia.

De este modo, en términos generales, en 2017 la mitad de las personas encuestadas hablaban de "extranjeros" cuando se mencionaba la procedencia de algunos alumnos compañeros de clase -preguntas $1 \mathrm{y}$ 2 -, siendo más rotunda dicha asociación de término a los alumnos alemanes $(65 \%)$ que a los peruanos $(49,7 \%)$. De igual manera sucedía con el término "inmigrante". En las preguntas 3 y 4, cuando se mencionaba a los vecinos de piso senegaleses o vendedores de calle peruanos, ambos eran vinculados al término "inmigrante", en términos generales, siendo dicha asociación mucho más significativa $(79,5 \%)$ en el caso del vendedor ambulante. En cierto modo parecía entreverse que, si bien la procedencia de las personas en algunos casos puede vincularle a un término u otro -inmigrante o extranjero-, parece que las personas entrevistadas veían más claro el vínculo entre capacidad económica y el término en cuestión. Así, una persona con mayor poder adquisitivo o mejor situación económica era vinculada al término "extranjero", frente a una de inferior posición económica, quien era catalogada como "inmigrante". De este modo, las dos primeras preguntas -que implican nivel de estudios y/o económico- muy posiblemente eran interpretadas, sobre todo en el caso de los encuestados universitarios del centro privado y del Colegio Inglés, como que si sus compañeros de clase podían pagarse los estudios en su mismo centro (centros privados ambos), posiblemente fuera porque económicamente tenían recursos y, por tanto, eran “extranjeros". Algo que no sucedía en el caso del centro público (escuela de infantil y 
primaria), con modelo educativo $\mathrm{A}$ y $\mathrm{D}^{26}$, donde el profesorado, de forma mayoritaria $(77,8 \%)$, entendía que sus alumnos peruanos eran inmigrantes en unos porcentajes muy superiores a cuando éstos eran alemanes $(44,4 \%)$, posiblemente al interpretar que una persona sin recursos no tiene más remedio que acudir a la enseñanza pública, mientras que la que tiene recursos puede elegir entre la pública, la privada o la concertada ${ }^{27}$.

Así, en ambos años las personas encuestadas parecen asociar las situaciones de mayor vulnerabilidad social y económica principalmente con el término "inmigrante"; y lo contrario con el de "extranjero", aunque habiendo diferencias en las respuestas según colectivos.

\section{Cruce de resultados: encuestas y noticias}

Tras el análisis de los resultados de las encuestas se observaba que, a priori, la sociedad vasca tiende a catalogar a las personas foráneas en función de una serie de variables, y es en función de ellas que se referirá a unos y otros como inmigrantes o extranjeros. Donde la palabra "extranjero" queda vinculada a una serie de características más positivas, frente a una carga negativa e incluso peyorativa en el caso de la palabra "inmigrante". El porqué de dicha distinción terminológica abrió una vía nueva dentro del estudio donde se planteaba que la percepción de lo que es un inmigrante y un extranjero, y el uso que habitualmente la sociedad vasca hace de dichos términos está totalmente condicionado por lo que los medios de comunicación les transmiten. De ahí que se realizara un rastreo a través de los medios de todas (o muchas) aquellas noticias que mencionaran alguno de esos dos términos -inmigrante o extranjero- para comprobar si en ellas también

\footnotetext{
${ }^{26}$ Modelo educativo A, es un modelo donde la lengua vehicular es el castellano y sólo tienen las asignaturas de lengua extranjera y euskera en diferente idioma. Modelo educativo D, es un modelo donde la lengua vehicular es el euskera y tan sólo las asignaturas de lengua extranjera y lengua castellana se dan en otro idioma.

${ }^{27}$ La diferencia entre enseñanza pública, privada y concertada, grosso modo, radica en que en la primera tanto los recursos como la gestión del centro es pública (en el caso del País Vasco es del Gobierno Vasco); en la privada tanto la gestión como los recursos son privados; y en la concertada gran parte de los recursos provienen de lo público pero la gestión es privada (con una muy escasa intervención de lo público).
} 
se hacía un uso discriminado de los mismos, asociando uno con factores o aspectos más positivos de la sociedad y la economía, y el otro con situaciones de carga negativa.

En este caso se detectó que en torno al 77\% de las noticias que hablaban de "extranjeros" lo hacían en términos positivos, vinculándolo al ámbito económico y/o deportivo; mientras que las referentes a "inmigrantes", en su gran mayoría (más del 90\%) estaban asociadas a la irregularidad/ilegalidad, conflictividad o ayudas sociales. (Tabla 3.)

Tabla 3. Vinculación en los medios de comunicación del término "inmigrante" y "extranjero" según aspectos positivos y negativos (categorías) (2002-2016) ( $\mathrm{n}^{\circ}$ noticias y \% por categorías respecto del total de noticias de inmigrantes y extranjeros respectivamente) ${ }^{28}$

\begin{tabular}{|c|c|c|c|c|}
\hline & \multicolumn{2}{|c|}{ INMIGRANTE } & \multicolumn{2}{|c|}{ EXTRANJERO } \\
\hline & № noticias & $\%$ & № noticias & $\%$ \\
\hline Irregularidad/ilegalidad (sin papeles, valla Melilla, pateras,...) & 1.358 & 49,0 & 92 & 4,1 \\
\hline Conflictos (robos, violencia,...) & 624 & 22,5 & 302 & 13,6 \\
\hline Ayudas sociales $(\mathrm{RGI}, \ldots)$ & 505 & 18,2 & 40 & 1,8 \\
\hline Situaciones de vulnerabildiad & 210 & 7,6 & 45 & 2,0 \\
\hline Empresarios/poder adquisitivo & 75 & 2,7 & 1.062 & 47,7 \\
\hline Ocio, cultura y deporte (turismo, artistas, deportistas, ...) & 0 & 0,0 & 684 & 30,7 \\
\hline TOTAL NOTICIAS & 2.772 & & 2.225 & \\
\hline
\end{tabular}

Fuente: elaboración propia.

Claramente, un uso discriminado de los términos por parte de los medios de comunicación, donde estos no son utilizados según su significado real sino en función de determinadas características, provoca que ambos términos acaben significándose para la sociedad en general más con lo segundo que con lo primero. Dicho en otras palabras, el significado atribuido por los medios a los términos inmigrante y extranjero a menudo está alejado de su significado real y

${ }^{28}$ RGI: Renta de Garantía de Ingresos. Para obtener mayor información sobre la RGI véase: http://www.euskadi.eus/gobiernovasco/contenidos/ayuda subvencion/1201/es_5401/es_18720.html, http://www.lanbide.euskadi.eus/rgi/-/informacion/que-es-la-rgi/ 
asociado a determinadas características específicas lo que contribuye a que la asimilación por parte de la sociedad de ambos términos quede alejada de la realidad, impulsando la discriminación de unos colectivos frente a otros, al asociar aspectos más negativos a la figura del inmigrante que a la del extranjero. Esta transmisión de los medios se hace progresivamente, de forma más o menos sutil, presentando diferencias entre inmigrantes y extranjeros que radican más en su estatus económico y social que en su estatus jurídico, a través de un suministro constante de noticias. No es de extrañar, por lo tanto, que la sociedad acabe utilizando los términos de la misma forma en la que las propias noticias analizadas lo hacían, de tal manera que las categorías en las que éstas estaban subdivididas (irregularidad, ocio...) acaban convirtiéndose en el contenido de cada uno de los términos.

Así pues, cuando en la encuesta se preguntaba por las diferencias entre extranjero e inmigrante y se pedía que se definieran ambos conceptos (pregunta 5 de la encuesta), en muchas ocasiones las personas que respondían no eran capaces de determinar dichas diferencias, sin embargo, sí percibían connotaciones negativas y positivas entre uno y otro término.

Esto se observaba tanto en 2009 como en 2017. En ambos años la mayoría de respuestas aun no siendo correctas desde el punto de vista del significado real de los términos, sin embargo, sí eran coincidentes entre sí al vincular al inmigrante con la idea de necesidad u obligatoriedad en su llegada, la permanencia, la supervivencia, la mejora respecto de su situación en origen, la ilegalidad, los "sin papeles", la desconfianza o la pobreza; mientras que hablaban de turistas, de estudiantes, de regulares o legales, de europeos o norteamericanos, de ricos, de gente que viene por un tiempo y de forma voluntaria,... cuando se referían al extranjero $^{29}$. De este modo, mientras que en 2009 once de los ochenta y tres encuestados $(13,3 \%)$ definían correctamente ambos términos, siendo el colectivo de sociología casi en su totalidad quienes parecían tener clara la diferencia existente entre ellos -8/9 definieron correctamente el término extranjero y $9 / 9$ el de inmigrante; en 2017 el 14\% se aproximaban a la definición de inmigrante, pero

\footnotetext{
${ }^{29}$ Lo prolijo de las respuestas a esta quinta pregunta dificulta la aportación de las mismas al completo en este caso, aunque la explotación de las mismas conforman las conclusiones referidas.
} 
tan sólo el 5,7\% hacía lo correspondiente con la de extranjero. En 2017 fue el grupo de $4^{a} \mathrm{ESO}$ quien porcentualmente más aciertos acometía, a pesar de que su aportación era menos significativa que la correspondiente a la del alumnado de $2^{\circ}$ de sociología en 2009 -2/27 definían correctamente al extranjero y $3 / 27$ hacían lo propio con el inmigrante).

En definitiva, tras cruzar los resultados obtenidos de las dos partes de la investigación a lo largo del tiempo -encuestas y rastreo de noticias entre 2009 y 2017-, parece evidente que los medios de comunicación influyen directamente sobre la sociedad en general, manteniendo y avivando las diferencias entre extranjeros e inmigrantes, favoreciendo positivamente a los primeros y negativamente a los segundos, algo que posteriormente se reproduce y materializa en las respuestas de las personas encuestadas quienes, en su gran mayoría, presentan una idea de la imagen del inmigrante como una persona ilegal, pobre y desesperado, en contraposición a la del extranjero que viene como turista, con glamour, rico y regular/legal. Imágenes que acaban afianzándose en un discurso recurrente y popular con el paso del tiempo, y que no favorecen la integración de muchas de las personas recién llegadas al país.

\section{¿Estamos ante un lenguaje dirigido?}

En el apartado anterior se referían los resultados del rastreo de noticias en los medios que recogían los términos inmigrante y extranjero, y se concluía que había evidencias de una clara dualización de la migración no por cuestiones jurídico-legales sino por aspectos económicosociales que posteriormente era trasladada a la sociedad en general, quien asimilaba ambos conceptos en función de dicha dualización y no de la realidad de los mismos. Sin embargo, esta perversión de las palabras no queda circunscrita al ámbito de las migraciones, sino que va más allá. Fiel muestra de ello es el pequeño estudio que se lleva haciendo en la Cámara Bilbao University Business School desde 2009.

En este caso, al alumnado de tercero y primero de carrera se le viene planteando un acertijo para el cual no son capaces de encontrar respuesta en el 90\% de los casos (en el mejor de los años), posiblemente como consecuencia de haber utilizado una palabra que está totalmente asociada al sexo masculino, si bien es totalmente válida para el sexo 
femenino también. Se trata de la palabra "eminencia". La incapacidad del alumnado para asociar dicha palabra con una mujer impedía que pudieran dar con la solución correcta, independientemente de que estas personas (chicos y chicas en porcentajes bastante parejos) pudieran tacharse de machista o no. Es más, muy posiblemente habiendo pocas personas que se identificaran como machista. Sin embargo, el imaginario colectivo ha hecho que, a pesar de estar concienciados/as con la igualdad de derechos y oportunidades entre hombres y mujeres, tengamos tan interiorizados algunos matices que nos hacen incapaces de asociar determinadas palabras con determinados contenidos o características; algo que también en el ámbito de las migraciones con los términos inmigrante y extranjero.

A continuación, se recoge la tabla 4 en la que se muestran las respuestas al acertijo plantado al alumnado de tercero y primero de universidad entre los años 2009-2017.

Tabla 4. Respuestas al Acertijo (número de respuestas correctas sobre total de participantes y porcentaje de respuestas correctas, por año) (2009-2017)

\begin{tabular}{cccccccccccccc} 
& \multicolumn{2}{c}{$\mathbf{2 0 0 9}$} & \multicolumn{2}{c}{$\mathbf{2 0 1 0}$} & \multicolumn{2}{c}{$\mathbf{2 0 1 1}$} & $\mathbf{2 0 1 3}$ & $\mathbf{2 0 1 4}$ & $\mathbf{2 0 1 6}$ & $\mathbf{2 0 1 7}$ \\
\hline $3^{\circ}$ Carrera & {$[2 / 60]$} & $3,3 \%$ & {$[1 / 81]$} & $1,2 \%$ & {$[2 / 68]$} & $2,9 \%$ & & & & & & & \\
\hline $1^{\circ}$ Carrera & & & & {$[3 / 95]$} & $3,2 \%$ & {$[0 / 77]$} & $0,0 \%$ & {$[3 / 79]$} & $3,8 \%$ & {$[8 / 77]$} & $10,4 \%$ & {$[2 / \mathbf{1 0 2}]$} & $2,0 \%$ \\
\hline
\end{tabular}

Fuente: elaboración propia.

\section{Conclusiones}

Cuando se analiza en líneas generales un tema como el de las migraciones, desde las propias sociedades receptoras cuesta admitir el fenómeno inmigratorio como un componente normal de los asuntos humanos. En este sentido, el profesor Bob Sutcliffe (1998) apunta que seguimos con la idea de que nacemos ligados a un país y debemos quedarnos en él, de modo que se mantengan nuestras raíces y cultura. La idea de monoculturalidad, de uniformidad étnica, de un nosotros homogéneo son fuerzas motrices en el pensar habitual, en las cosmovisiones normales de los receptores. La idea de homogeneidad ha sido una constante en el pensamiento, tanto teórico como cotidiano, de la modernidad, que piensa que a un Estado le corresponde una única nación, una única cultura y, evidentemente, sólo unos nacionales. A 
esta perspectiva se le ha denominado como nacionalismo metodológico.

Esta visión normalizante ha llevado a considerar la inmigración como un fenómeno inusual y en paralelo, que lo que hace la mayoría -no emigrar- no necesita explicación. Sin embargo, como bien dice Sutcliffe, centrar las teorías en las características de las minorías es contribuir muy sutilmente, aun sin pretenderlo, a la impresión de que su conducta es a-normal, haciendo que se vea la migración internacional como un fenómeno irregular que necesita ser explicado, derivándose de ello la generación de prejuicios por parte de la sociedad autóctona del país de destino contra la propia migración. Prejuicios en los que nos parábamos para entender su porqué.

A partir de la hipótesis de que existía una relación directa entre medios de comunicación y percepción social de la migración, sacábamos varias líneas de investigación. Una de ellas analizaba si la terminología usada en los medios era la adecuada y si ésta, además, influía en la configuración del imaginario colectivo, de su vocabulario y discurso popular acerca de inmigrantes y extranjeros. De ser cierto dicho vínculo, la población receptora sería fácilmente manipulable a expensas de unos intereses determinados. Algo delicado en un país que desde finales del siglo XX, principios del XXI ve cómo su sociedad cada vez es más plural y menos homogénea, consecuencia directa de los movimientos migratorios internacionales vividos.

Así pues, tras el estudio de campo en varios centros educativos en 2009 y 2017, y del rastreo de noticias en los medios de comunicación sobre la imagen que las palabras inmigrante y extranjero proyectan en la sociedad y que acaban configurándose como parte del lenguaje popular llegábamos a una serie de conclusiones.

En primer lugar, se detecta que la población vasca sigue manteniendo la idea de una inmigración dualizada donde el extranjero sería la cara positiva de la misma, frente a un inmigrante cuya imagen está más denostada. Así tanto en 2009 como en 2017 aparecía un vínculo entre procedencias y términos, conectando al inmigrante con los países menos desarrollados y al extranjero con los más desarrollados. Vínculo que era aún más determinante si la variable procedencia se cambiaba por la de poder adquisitivo o nivel económico, lo que hacía que algunas 
personas cuyo país de origen fuera un país menos desarrollado podían ser descritas como extranjeras si se entendía que estaban en una posición económica media-alta o alta.

En segundo lugar, se ratificaba lo desvirtuados que estaban los términos inmigrante y extranjero respecto de su significado original o real. En términos asocia la ilegalidad, irregularidad, supervivencia, económicamente deprimido... con el inmigrante; al igual que al extranjero se le identifica como turista, europeo o norteamericano, solvente económicamente y con nivel de estudios alto o puestos de trabajo importantes.

$Y$ en tercer lugar se aprecia la relación entre la presentación en los medios de las personas inmigrantes y extranjeras unidas a determinadas características y circunstancias, con la percepción que la sociedad acaba teniendo de ambas y que reproduce en sus discursos diarios entre sus convecinos. Así, que más del $90 \%$ de las noticias que hablaban de inmigrantes estuvieran relacionadas con circunstancias poco favorables (pateras, sin papeles, RGI,...), o que más del 70\% de las referentes a los extranjeros fueran noticias relacionadas con el mundo empresarial, el deporte, el ocio o la cultura, acaban influyendo directamente sobre el imaginario colectivo dotando al extranjero de una posición de favorito, frente a un inmigrante que recibirá mayores rechazos y obstáculos por parte de la población receptora.

En estudios anteriores (Garcia-Azpuru, 2016) se constataba que una sobre-estimulación informativa relativa a la inmigración menos favorecida o en situaciones de mayor vulnerabilidad unida a la posibilidad de recibir la información sesgada o a través de lo que Sami Näir denomina "metáforas inquietantes" 30 provocaba, en la mayor parte de la población, la percepción de una realidad virtual en la que no sólo la inmigración era demonizada -más concretamente la inmigración económica-, sino que era sobrerrepresentada dentro del país de recepción. En concreto, se observaba que según fuera el tratamiento que hicieran los medios de comunicación acerca de la migración, así

\footnotetext{
${ }^{30}$ Näir habla de "metáforas inquietantes" en relación al fenómeno de la inmigración. Adjetivaciones o descripciones de la inmigración con términos cargados de valor negativo como es el caso de "marea", "avalancha",... Donde el que salta una valla pasar de ser saltador a ser "asaltante", por ejemplo.
} 
fluctuaría la percepción que la sociedad autóctona tenía sobre la misma, presentándose una sociedad vulnerable y fácilmente manipulable y sugestionable por los propios medios.

De nuevo se podría confirmar dicha situación: unos medios de comunicación que presentan al inmigrante como la cara oscura de la migración, alguien en estado de supervivencia y cuya llegada suele efectuarse de forma irregular; y al extranjero con la cara amable de la misma, como la persona que viene por placer o voluntariamente, siendo económicamente beneficioso para el país; dualizándose así la inmigración en sí misma en dos caras de una misma moneda. Imagen que, además, es asumida, interiorizada y reproducida por la sociedad receptora, ajena en gran medida a la realidad y que, sin embargo, vive la percepción de los hechos como una verdad absoluta y actúa en su día a día en función de esos discursos aprendidos, donde el lenguaje parece una marioneta en manos de fines económico y políticos.

\section{Bibliografía}

Aierdi, Xabier (2006): Inmigración extranjera y opinión pública: ¿Estados de opinión o estados de ánimo? Panorámica de la inmigración, $\mathrm{n}^{\mathrm{o}}$ 13, Ikuspegi, Bilbao, pp. 1-4.

Garcia Azpuru, Amaia (2017): Casualidad o causalidad de la afluencia inmigratoria en la Comunidad Autónoma de Euskadi, Tesis de Doctorado, HEGOA, Universidad del País Vasco/Euskal Herriko Unibertsitatea, Bilbao.

Garcia Azpuru, Amaia (2016): "Influencia de los medios de comunicación en la sobrerrepresentación de los flujos migratorios en España", en Herreros, J. y Mateos, C. (coord.), Del verbo al bit, Universidad de La Laguna, Tenerife, pp. 723742 .

Garcia Azpuru, Amaia (2009): Algunas percepciones sobre la funcionalidad económica de la inmigración en la sociedad vasca, tesina fin de máster Globalización y Desarrollo, HEGOA, Universidad del País Vasco/Euskal Herriko Unibertsitatea, Bilbao.

Garcia Azpuru, Amaia (2017): "Inmigrantes y Extranjeros, ¿dos caras de una misma moneda?”, en Herrero, F.J. y Trenta, M. (coord.), 
El fin de un modelo de política, Universidad de La Laguna, Tenerife, pp. 471-494. ISBN: 978-84-16458-87-5

Sutcliffe, Bob (1998): Nacido en otra parte. Un ensayo sobre la migración internacional, el desarrollo y la equidad, HEGOA, UPV/EHU, Bilbao.

\section{Webgrafía:}

www.elcorreo.com

www.elmundo.es

www.elpais.com

www.expansion.com

www.huffingtonpost.es

www.lavanguardia.com

www.antena3.com

www.cuatro.com

www.eitb.eus

www.lasexta.com

www.rtve.es

www.telecinco.es

\section{Anexos}

\section{Anexo 1: Encuesta Inmigrante Vs Extranjero}

\section{Preguntas:}

Si en tu clase hubiera 3 alumnos peruanos los catalogarías como... Inmigrantes

Extranjeros

Otros:

Si en tu clase hubiera 2 alumnos alemanes los catalogarías como... Inmigrantes

Extranjeros

Otros:

Si en el piso de al lado se van a vivir 2 jóvenes senegaleses, los catalogarías como...

Inmigrantes 


\section{Extranjeros}

Otros:

Los peruanos que venden por la calle (top-manta) cinturones, relojes, collares..., los catalogarías como...

Inmigrantes

Extranjeros

Otros:

¿Detectas diferencias entre Inmigrante y Extranjero? (Escribe qué entiendes por ambos conceptos y por un ejemplo de quién sería cada uno de los conceptos, si es que los ves diferentes)

\section{9}

Grupo 1: Estudiantes de $1^{\circ}$ de carrera (Comercio Exterior y Marketing Internacional), universidad privada (EUCCB), sin nociones sobre el tema. Edad: 18-20 años

Grupo 2: Estudiantes de $3^{\circ}$ de carrera (Comercio Exterior y Marketing Internacional), universidad privada (EUCCB), con nociones básicas sobre el tema. Edad: 21-25 años

Grupo 3: Estudiantes de $2^{\circ}$ de carrera (Sociología), universidad pública (UPV/EHU). Edad: 40-50 años

Grupo 4: Profesorado de infantil y primario en escuela pública de Bilbao (Cervantes Eskola) con modelo A y D. Edad: 40-50 años

\section{7}

Grupo 1: Estudiantes de $1^{\circ}$ de carrera (Gestión y Marketing Empresarial), universidad privada (CámaraBilbaoUBS), sin nociones sobre el tema. Edad: 18-20 años

Grupo 2: Estudiantes de $3^{\circ}$ de carrera (Gestión y Marketing Empresarial), universidad privada (CámaraBilbaoUBS), con nociones básicas sobre el tema. Edad: 21-25 años

Grupo 3: Estudiantes de $4^{\circ}$ ESO, colegio privado (Colegio Inglés - St. George College). Edad: 15-16 años

Grupo 4: Profesorado de infantil y primario en escuela pública de Bilbao (Cervantes Eskola) con modelo A y D. Edad: 40-50 años

\section{Anexo 2: Explotación de los resultados de las encuestas - Año 2009}

Resultados a la pregunta 1. Si en tu clase hubiera tres alumnos peruanos los catalogarías como...

\begin{tabular}{lllllll} 
& Total & $\mathbf{0}$ & $\mathbf{1}^{\mathbf{o}}$ carrera & $\mathbf{3}^{\mathbf{o}}$ carrera & Sociología & $\begin{array}{l}\text { Profesorad } \\
\mathbf{o}\end{array}$ \\
\hline $\begin{array}{l}\text { Inmigrante } \\
\text { s }\end{array}$ & 41 & 49,4 & 51,7 & 12,0 & 77,8 & 80,0 \\
Extranjeros & 18 & 21,7 & 34,5 & 20,0 & 11,1 & 10,0 \\
Otros & 24 & 28,9 & 13,8 & 68,0 & 11,1 & 10,0 \\
\hline Total & $\mathbf{8 3}$ & $\mathbf{1 0 0}$ & {$[\mathbf{2 9}] \mathbf{1 0 0}$} & {$[\mathbf{2 5}] \mathbf{1 0 0}$} & [9] 100 & {$[\mathbf{2 0} \mathbf{1 0 0}$}
\end{tabular}


Resultados a la pregunta 2. Si en tu clase hubiera 2 alumnos alemanes los catalogarías como...

\begin{tabular}{lllllll} 
& Total & $\mathbf{\%}$ & $\mathbf{1}^{\mathbf{0}}$ carrera & $\mathbf{3}^{\mathbf{0}}$ carrera & Sociología & $\begin{array}{l}\text { Profesorad } \\
\mathbf{0}\end{array}$ \\
\hline $\begin{array}{l}\text { Inmigrante } \\
\mathrm{s}\end{array}$ & 11 & 13,4 & 3,4 & 0,00 & 66,7 & 21,1 \\
Extranjeros & 50 & 61,0 & 82,8 & 36,0 & 22,2 & 78,9 \\
Otros & 21 & 25,6 & 13,8 & 64,0 & 11,1 & 0,0 \\
\hline Total & $\mathbf{8 2}$ & $\mathbf{1 0 0}$ & {$[\mathbf{2 9}] \mathbf{1 0 0}$} & {$[\mathbf{2 5}] \mathbf{1 0 0}$} & {$[\mathbf{9}] \mathbf{1 0 0}$} & {$[\mathbf{1 9 ]} \mathbf{1 0 0}$} \\
\hline
\end{tabular}

Resultados a la pregunta 3. Si en el piso de al lado se van a vivir dos senegaleses, los catalogarías como...

\begin{tabular}{lllllll} 
& Total & $\mathbf{\%}$ & $\mathbf{1}^{\mathbf{0}}$ carrera & $\mathbf{3}^{\mathbf{0}}$ carrera & Sociología & $\begin{array}{l}\text { Profesorad } \\
\mathbf{0}\end{array}$ \\
\hline Inmigrante & 49 & 59,8 & 55,2 & 32,0 & 77,8 & 94,7 \\
$\mathrm{~s}$ & 49 & 15,9 & 24,1 & 16,0 & 11,1 & 5,3 \\
Extranjeros & 13 & 24,4 & 20,7 & 52,0 & 11,1 & 0,0 \\
\hline Otros & 20 & $\mathbf{1 0 0}$ & {$[\mathbf{2 9}] \mathbf{1 0 0}$} & {$[\mathbf{2 5}] \mathbf{1 0 0}$} & {$[\mathbf{9 ]} \mathbf{1 0 0}$} & {$[\mathbf{1 9 ]} \mathbf{1 0 0}$} \\
\hline Total & $\mathbf{8 2}$ & $\mathbf{1 0 0}$ &
\end{tabular}

Resultados a la pregunta 4. Los peruanos que venden por la calle (top-manta), relojes, collares..., lo catalogarías como...

Profesorad

\begin{tabular}{|c|c|c|c|c|c|c|}
\hline & Total & $\%$ & $1^{\circ}$ carrera & $3^{\circ}$ carrera & Sociología & \\
\hline Inmigrante & & & & & & \\
\hline s & 47 & 82,5 & 75,9 & nd & 77,8 & 94,7 \\
\hline Extranjeros & 3 & 5,3 & 6,9 & nd & 0,0 & 5,3 \\
\hline Otros & 7 & 12,3 & 17,2 & nd & 22,2 & 0,0 \\
\hline Total & 57 & 100 & [29] 100 & [0] 100 & [9] 100 & [19] 100 \\
\hline
\end{tabular}

Nota: no hay datos para los alumnos de $3^{\circ}$ de carrera (nd) puesto que, inicialmente se realizó un cuestionario a este colectivo con respuestas abiertas a todas las preguntas y no incluyendo la pregunta cuatro sobre los peruanos del top-manta. Es por ello que en algunas de sus respuestas, como es el caso de la primera, no sabiendo muy bien qué contestar, la mayoría optó por poner "compañeros de clase". Esta primera cata hizo que se replanteara el cuestionario 
modificándolo ligeramente, con el fin de que para el resto de colectivos seleccionados la encuesta tuviera opciones claras a elegir como respuesta para poder hacer posteriormente, una comparación más eficaz del tema objeto de estudio. Además, se subsanó el principio de que las opciones fueran mutuamente excluyentes.

Anexo 3: Explotación de los resultados de las encuestas - Año 2017

Resultados a la pregunta 1. Si en tu clase hubiera tres alumnos peruanos los catalogarías como...

\begin{tabular}{lllllll} 
& Total & $\mathbf{0}$ & $\mathbf{1}^{\mathbf{o}}$ carrera & $\mathbf{4}^{\mathbf{o}}$ carrera & $\mathbf{4}^{\mathbf{o}} \mathbf{E S O}$ & $\begin{array}{l}\text { Profesorad } \\
\mathbf{0}\end{array}$ \\
\hline $\begin{array}{l}\text { Inmigrante } \\
\mathrm{s}\end{array}$ & 50 & 31,8 & 23,3 & 15,4 & 44,4 & 77,8 \\
Extranjeros & 78 & 49,7 & 52,3 & 73,1 & 48,1 & 5,6 \\
Otros & 29 & 18,5 & 24,4 & 11,5 & 7,4 & 16,7 \\
\hline Total & $\mathbf{1 5 7}$ & $\mathbf{1 0 0}$ & {$[\mathbf{8 6}] \mathbf{1 0 0}$} & {$[\mathbf{2 6}] \mathbf{1 0 0}$} & {$[\mathbf{2 7}] \mathbf{1 0 0}$} & {$[\mathbf{1 8}] \mathbf{1 0 0}$} \\
\hline
\end{tabular}

Resultados a la pregunta 2. Si en tu clase hubiera 2 alumnos alemanes los catalogarías como...

\begin{tabular}{lllllll} 
& Total & $\mathbf{0}$ & $\mathbf{1}^{\mathbf{o}}$ carrera & $\mathbf{4}^{\mathbf{o}}$ carrera & $\mathbf{4}^{\mathbf{o}}$ ESO & $\begin{array}{l}\text { Profesorad } \\
\mathbf{0}\end{array}$ \\
\hline Inmigrante & & 19,1 & 11,6 & 7,7 & 37,0 & 44,4 \\
$\mathrm{~s}$ & 30 & $\mathbf{1}, 6$ & 80,8 & 59,3 & 33,3 \\
Extranjeros & 102 & 65,0 & 68,6 & 11,5 & 3,7 & 22,2 \\
Otros & 25 & 15,9 & 19,8 & {$[\mathbf{2 6}] \mathbf{1 0 0}$} & {$[\mathbf{2 7}] \mathbf{1 0 0}$} & {$[\mathbf{1 8}] \mathbf{1 0 0}$}
\end{tabular}

Resultados a la pregunta 3. Si en el piso de al lado se van a vivir dos senegaleses, los catalogarías como...

\begin{tabular}{lllllll} 
& Total & $\mathbf{0}$ & $\mathbf{1}^{\mathbf{o}}$ carrera & $\mathbf{4}^{\mathbf{0}}$ carrera & $\mathbf{4}^{\mathbf{0}}$ ESO & $\begin{array}{l}\text { Profesorad } \\
\mathbf{0}\end{array}$ \\
\hline $\begin{array}{l}\text { Inmigrante } \\
\mathrm{s}\end{array}$ & 80 & 51,0 & 41,9 & 61,5 & 51,9 & 77,8 \\
Extranjeros & 52 & 33,1 & 3,72 & 26,9 & 44,4 & 5,6 \\
Otros & 25 & 15,9 & 20,9 & 11,5 & 37,7 & 16,7 \\
\hline Total & $\mathbf{1 5 7}$ & $\mathbf{1 0 0}$ & {$[\mathbf{8 6}] \mathbf{1 0 0}$} & {$[\mathbf{2 6}] \mathbf{1 0 0}$} & {$[\mathbf{2 7}] \mathbf{1 0 0}$} & {$[\mathbf{1 8}] \mathbf{1 0 0}$} \\
\hline
\end{tabular}


Resultados a la pregunta 4. Los peruanos que venden por la calle (top-manta), relojes, collares..., lo catalogarías como...

\begin{tabular}{lllllll} 
& Total & $\mathbf{\%}$ & $\mathbf{1}^{\mathbf{0}}$ carrera & $\mathbf{4}^{\mathbf{0}}$ carrera & $\mathbf{4}^{\mathbf{0}}$ ESO & $\begin{array}{l}\text { Profesorad } \\
\mathbf{0}\end{array}$ \\
\hline Inmigrante & $\mathbf{1}$ & 79,5 & 64,0 & 65,4 & 70,4 & 77,8 \\
$\mathrm{~s}$ & 105 & 22,7 & 20,9 & 23,1 & 18,5 & 5,6 \\
Extranjeros & 30 & 16,5 & 11,1 & 16,7 \\
Otros & 22 & 16,7 & 11,5 & {$[\mathbf{2 6}] \mathbf{1 0 0}$} & {$[\mathbf{2 7}] \mathbf{1 0 0}$} & {$[\mathbf{1 8}] \mathbf{1 0 0}$} \\
\hline Total & $\mathbf{1 5 7}$ & $\mathbf{1 0 0}$ & {$[\mathbf{8 6}] \mathbf{1 0 0}$} & $\mathbf{[ 2 6}$ \\
\hline
\end{tabular}

\section{Anexo 4: Acertijo interesante}

Recuerde que no hay trampas, no hay cosas escondidas, todo está a la vista. Algo más: si no conoce el ejemplo, permítame una sugerencia.

Trate de pensarlo sólo porque vale la pena, en particular, porque demuestra que lo que usted cree sobre usted mismo a lo mejor no es tan cierto. O, en todo caso, es incompleto.

Antonio, padre de Roberto, un niño de 8 años, sale conduciendo desde su casa en la Capital Federal y se dirige rumbo a Mar del Plata. Roberto, va con él.

En el camino se produce un terrible accidente. Un camión, que venía de frente, se sale de su carril de la autopista y embiste de frente al coche de Antonio.

El impacto mata instantáneamente a Antonio, pero Roberto sigue con vida. Una ambulancia de la municipalidad de Dolores llega casi de inmediato, advertida por quienes fueron ocasionales testigos, y el niño es trasladado al hospital.

Según llega, los médicos de guardia comienzan a tratar al nene con mucha dedicación, pero después de charlar entre ellos y estabilizarle las constantes vitales, deciden que no pueden resolver el problema de Roberto.

Necesitan consultar. Además, advierten el riesgo de trasladar al niño y, por eso, deciden dejarlo internado allí, en Dolores. 
Tras las consultas pertinentes, se comunican con el Hospital de Niños de la Capital Federal y finalmente conversan con una eminencia en el tema a quien ponen en autos de lo ocurrido. Como todos concuerdan que lo mejor es dejar a Roberto en Dolores, la eminencia decide viajar directamente desde Buenos Aires hacia allá. Y lo hace.

Los médicos del lugar le presentan el caso y esperan ansiosos su opinión. Finalmente, uno de ellos es el primero en hablar: "¿Está usted en condiciones de tratar al nene?", pregunta con un hilo de voz.

Y obtiene la siguiente respuesta:

- "¡Cómo no lo voy a tratar si es mi hijo!".

Bien, hasta aquí, la historia.

Está en usted el tratar de pensar una manera de que tenga sentido. Como no compartimos la habitación, o donde sea que usted esté, le insisto que no hay trampas, no hay nada oculto.

$\mathrm{Y}$ antes de que lea la solución, quiero agregar algunos datos:

a) Antonio no es el padrastro.

b) Antonio no es cura. 


\title{
¿Cómo se cuentan las migraciones?
} Los "otros" desde "nosotros". Una aproximación inicial a qué es "noticia" en cuanto al fenómeno migratorio en términos de la representación mediática de la "población extranjera" ${ }^{31 "}$

\author{
Ariet Castillo Fernández ${ }^{32}$ \\ Instituto de Migraciones, Universidad de Granada, España
}

\section{Resumen}

Mediante el estudio de fuentes de información como son los medios de comunicación de prensa escrita, analizaremos la construcción de categorías que tiene lugar desde seleccionados agentes comunicacionales (Instituto Nacional de Estadística y periódicos como son EL PAÍS y EL MUNDO) puesto que, pensamos, es a partir de los cuales construimos una parte de nuestras interpretaciones que, asimismo, desvelan la (re)presentación del llamado "problema de la inmigración". Migración que es otra, extranjera, inmigrante, extraña y

\footnotetext{
31 Población extranjera: Considerada aquí como toda aquella que no tiene nacionalidad española.

${ }^{32}$ Licenciada en Publicidad y Relaciones Públicas, UCM (2006-2011). Graduada en Antropología Social y Cultural, UNED (2011-2015). Cursando Máster Universitario en Investigación Antropológica y sus aplicaciones, UNED (20162018). Doctoranda del Programa de Estudios Migratorios, Universidad de Granada. Contratada predoctoral del Programa de Formación para el Profesorado Universitario (FPU17/05600) del Ministerio de Educación, Cultura y Deporte de España en el Departamento de Antropología Social y Cultural, Facultad de Filosofía y Letras de la Universidad de Granada.
} 
que afecta a nuestra población, la nacional, la española, la europea, la occidental. Por ende, se analizarán tanto las Notas de Prensa elaboradas por el INE (2002-2017) como los artículos publicados (2003-2017) en España en los medios de comunicación citados ya que son los periódicos los que elaboran las "noticias" relacionadas con la publicación de las Notas de ámbito estadístico.

Partiendo de un análisis documental, hemos ido conociendo y abordando los conceptos clave en torno al fenómeno migratorio vinculado a las ciencias de la comunicación, así como la posibilidad de análisis de discursos que aparecen en los medios. Para ello, nos hemos servido de programas de análisis cualitativos de datos como es Atlas.ti. Gracias a la extracción de informes, hemos desentrañado los términos clave, recurrentes, que aparecen constantemente en las Notas de Prensa, en primera instancia, para luego manifestarse en los discursos mediáticos en los periódicos. Así, el análisis crítico del discurso nos llevará a indagar sobre cómo se presenta el fenómeno de las migraciones, que se analiza de una manera "parcial" y para el que se construyen categorías que se trasladan al discurso público: una forma de construcción de los "otros" desde el "nosotros" en forma de alarma social. Una estrategia mediática que supone contar personas y esencializarlas de tal manera que estas poblaciones otras suponen ser una amenaza en términos numéricos e intensificadores que reflejan falta de calma y de normalidad; lo que nos traslada, al mismo tiempo, cierta preocupación reflejada en procesos de inclusión y exclusión de población. Una manera de "contabilidad" y "control" de las migraciones en España que desvela un proceso de alterización, una forma de representar al "otro" (extraño) mientras se construye el "nosotros" (normal).

Palabras clave: Migraciones, Población extranjera, Nos-otros, Representación mediática, Análisis crítico del discurso

\section{Introducción}

D RIMERO, partiremos de cómo se cuentan las migraciones. Para 1 responder a esta pregunta, es necesario considerar a los "otros" desde el "nosotros". Se trata pues de un estudio de la categorización social y sus sesgos, que se ponen de manifiesto en la representación 
mediática que se hace de las migraciones. Siendo las fuentes de información bien diversas, pondremos atención sobre los medios de comunicación por su influencia en la formación de la opinión pública puesto que es a partir de los cuales se generan las interpretaciones de las prácticas sociales. Por ende, nos parece importante identificar las tres posibles áreas temáticas sobre las que indagar en relación con el fenómeno migratorio: la producción por los medios, la noticia en sí misma y los efectos que causa su conocimiento.

En cuanto a la producción por los medios y partiendo del análisis de 17 Notas de Prensa (2002-2017) que cada año emite el Instituto Nacional de Estadística sobre los resultados estadísticos del Padrón Municipal de Habitantes, los medios elaboran las noticias. La citada fuente estadística se ha convertido en la forma de "contabilidad" y en una manera de tratar, así, el "control" de las migraciones en España. Las referencias que se hacen a la población nacional y a la "población extranjera" en las Notas desvelan ciertas representaciones tanto del fenómeno como de los sujetos de las migraciones, y es desde ellas que los medios de comunicación construyen las noticias que luego consumimos. Mediante un estudio exhaustivo del tratamiento de la "población extranjera" en los discursos mediáticos, hemos visto reflejado, indirectamente, un proceso de alterización, una forma de representar al "otro" (extraño) mientras se construye el "nos-otros" (normal). Esto es, el fenómeno migratorio sin hablar directamente de él que desvela el "problema de la inmigración" con su consecuente construcción de la diferencia y difusión de la desigualdad social (Castillo Fernández y García Castaño, 2018).

El estado de la cuestión parte de cómo la representación de la "población extranjera" en los medios da idea del citado fenómeno migratorio. Es notorio considerar que la mayoría de la población no asiste a diario de forma directa a cada uno de los acontecimientos que suceden en este mundo (Granados Martínez y García Castaño, 2008: 255). En las noticias, tanto en prensa como en TV, puede apreciarse que la llegada de inmigrantes extranjeros aparece constantemente y es el fenómeno migratorio el que se encuentra, además, entre los principales problemas presentados por los españoles en línea con preocupaciones como el paro y/o la vivienda entre otros (Granados Martínez y García Castaño, 2008). 
Para investigar qué y cómo son noticia las temáticas relacionadas con el fenómeno migratorio, nos hemos servido, en primera instancia, de fuentes estadístico-demográficas como son, sobre todo, el Censo y el Padrón Municipal de Habitantes para luego abordar las noticias que aparecen en los periódicos de tirada nacional. Todo ello sin olvidar los contenidos documentales referidos a los estudios de alterización, extranjerización, otredad y construcción de la diferencia en relación con las migraciones. Alteridad que en la representación mediática se teje como una especie de miedo al "otro" que justificaría la extranjerización, entendiéndola como todo lo relacionado con el/lo "extraño", lo ajeno a "nosotros" tratándose así de una construcción de la identidad nacional desde la alteridad y la otredad (Castillo Fernández y García Castaño, 2018: 8). Con ello, cabe preguntarse, respecto a ese "extraño" que sería el representado por la "población extranjera", ¿en qué términos se refiere a "extranjeros" y en cuáles a "inmigrantes"? Además, tener en cuenta en función de qué criterio se establece esta construcción de las mencionadas categorías y lo que conlleva dicha conformación en torno a los usos y prácticas concretas que conducen a esas textualizaciones; tanto entre quienes las producen (agencias diversas de comunicación) como en los usos y prácticas de quienes las interpretan.

En torno a las poblaciones consideradas, el participante principal (población nacional) no sostiene la misma perspectiva que el participante otro (población extranjera). Por ende, el primero no consigue transformarse a sí mismo en cuanto otro y, así, no parece construirse como una alteridad, pero sí, en cambio, presenta autoridad para construir a ese considerado como otro, una minoría que sería la que ocupa el lugar de los otros, extraños y que, ya en prensa escrita, llegan a constituir una amenaza (Castillo Fernández y García Castaño, 2018). Por tanto, nos parece importante mencionar cómo se presenta en los medios este "problema"; siempre frente a "nuestra" frontera nacional y frente a las fronteras de la UE (que también son "nuestras") y cómo este es considerado un problema para los gobiernos nacionales (los "nuestros" que son europeos, occidentales, comunitarios).

Respecto a los intereses políticos que esto supone, para Noam Chomsky (1988), los factores que intervienen en el establecimiento periodístico comprenden una alianza entre los medios de 
comunicación y los gobiernos. La teoría de la agenda-setting es el resultado experimental de una tesis que planteó Cohen (1963): “los medios pueden no acertar al decirnos cómo pensar sobre un determinado tema, pero sí cuando nos dicen sobre qué pensar".

En cuanto a los contenidos documentales, el proceso de conocer estas "noticias" nos conduce a la forma de representación en los medios de comunicación de masas y, con ello, a la lógica de las representaciones (Berger y Luckman, 1986) que se transfiere en el discurso cotidiano a la mayoría de la población. Además, se trata de un discurso que trata el fenómeno migratorio sin hablar directamente de él mientras se traslada un relato dominante y "común". Lo que presentan las noticias es de interés público y parece ser interés del público. Surgen al respecto algunos planteamientos en torno a qué es legitimado y qué puede transformar el discurso social. Desde esta perspectiva se descubre, tal como enuncian López-Escobar et al (1996: 9), la existencia de una elevada correlación entre las temáticas a los que dan importancia los medios y los que interesan a sus audiencias desvelando así jerarquías de los temas o "problemas" más destacados para la sociedad, los que impactan sobre el público y captan la atención respecto a lo relacionado con las migraciones. En esta línea, merece mención George Lakoff (2004) que muestra, a la hora de formar una opinión sobre la realidad, la relevancia que tienen los marcos mentales establecidos que contribuyen, a su vez, a generar discursos cargados de consecuencias y que transfieren el denominado, en los medios de comunicación, "problema de la inmigración".

Bañón Hernández (2014), por su parte, habla de la importancia de la autoridad de los medios, que actúan como constructores y transformadores de valores además de tener un papel protagonista en la formación y consolidación de valoraciones, desde una visión eurocéntrica. Respecto a las cuestiones de poder, desigualdad, en "El análisis del discurso", Van Dijk (1999: 33) expone una correlación del discurso imperante y los fenómenos de las migraciones que es relevante a nivel de terminología recurrente desde el análisis crítico del discurso. Tanto es así que dicho fenómeno se presenta de manera "parcial" al mismo tiempo que se construyen categorías. Se trataría de una estrategia mediática que reside en la "contabilidad" de personas además 
de en su esencialización que traslada el ya citado "problema de la inmigración”.

Continuando con las áreas temáticas que son de nuestro interés, el objeto teórico de este estudio centra su atención en las posibles repercusiones en términos de alarma social que se generan por los medios respecto al fenómeno migratorio y su "contabilidad" y "control" que repercuten sobre los sujetos. Por ende, hemos procedido a investigar cómo se conforman y "sesgan" las noticias partiendo de fuentes estadísticas como las representadas mediante las Notas de Prensa del INE y que luego alcanzan los medios periodísticos hasta llegar a los receptores finales quienes, tampoco podemos olvidar, son agentes activos.

Sin embargo, es relevante dar visibilidad y poner de manifiesto el tratamiento de la considerada "población extranjera" en los medios. Por ello, es relevante tener en cuenta lo que es legitimado y que puede transformar el discurso social como ya veríamos enunciado en García Castaño y Granados Martínez (2009) en relación con el uso mediático y generalizado de fuentes estadísticas como el Padrón que ostentan la autoridad para ofrecer datos relativos de la considerada como "población extranjera" en España. Estos datos permiten conocer los medios que construyen al denominado "otro" y, además, conocer cómo se construye la diferencia representada por ese "otro" inmigrante. Shaw (1972) llega a la conclusión de que los temas que alcanzan mayor cobertura mediática son los que se convierten en "noticia" y a los que el público presta atención. En torno a ello, Bañón Hernández (2002: 357) expone como el discurso reivindicativo generado por "ellos", por el exogrupo33, se percibe como un discurso desestabilizador que se encuentra mermado mediáticamente en su proceso de transmisión. En cambio, el discurso generado por "nosotros", el endogrupo 34, se transfiere como un discurso dominante. Aquí los medios juegan un papel principal pues como expondría Enrique Santamaría (2002: 167168), "la eficacia social del discurso sonoro y flotante sustenta la

\footnotetext{
${ }^{33}$ Exogrupo: Considerado por Bañón Hernández (2002) como el grupo que no es el "dominante". El discurso generado desde el "ellos", de los "otros" ${ }^{34}$ Endogrupo: Considerado por Bañón Hernández (2002) como el grupo que es el "dominante". El discurso generado desde el "nosotros"
} 
capacidad para objetivar, esencializar, cosificar, instituir e implantar en lo real aquello de lo que habla”.

Siendo así, nuestro principal objeto teórico será continuar indagando en la alarma social que generan los medios respecto a las migraciones y su "contabilidad" y "control". Investigar cómo se construyen las noticias partiendo de las Notas de Prensa del INE y cómo llegan estas a los medios y a la audiencia. Tomar en consideración, por tanto, cuál es el relato común que se considera legítimo y que es capaz de transformar el discurso social en relación con la representación mediática de la "población extranjera" en torno a las migraciones.

Prestando atención a lo anterior, parece relevante estudiar, así, esta representación en términos estereotípicos que clasifican y reifican a este sector de la población y en términos de alarma social que atentan contra la entendida "seguridad nacional"35. Una manera de abordar el fenómeno migratorio a través de la representación mediática y sus repercusiones en la sociedad en términos de xenofobia, discriminación y desigualdad. A través de los términos recurrentes utilizados en los medios que cuantifican dicha población, analizar y reflejar "lo noticioso", el interés que reside en la "contabilidad" de la "población extranjera" y en su "jerarquización social" que será la que formará la "noticia" en sí misma. Desvelar, por ende, los discursos de poder que imperan y se trasladan a la sociedad desentrañando las percepciones, asimismo, de la propia "población extranjera" en torno al fenómeno migratorio y su representación mediática, sobre todo, en prensa escrita; pero también, a posteriori, en prensa digital y los consecuentes foros de opinión y discusión. Con ello, y gracias al amplio análisis en curso, se puede observar el poder de lo normativo y como ello se contrapone en términos de alteridad, otredad y que supone, a su vez, procesos de identificación. Una lógica de las representaciones que, mediante el uso de estereotipos y prejuicios que construyen la diferencia y la desigualad, crean los discursos mediáticos, extranjerizantes y consagrados por la

\footnotetext{
${ }^{35}$ Seguridad Nacional: La acción del Estado dirigida a proteger la libertad y el bienestar de sus ciudadanos, a garantizar la defensa de España y sus principios y valores constitucionales, así como a contribuir junto a nuestros socios y aliados a la seguridad internacional en el cumplimiento de los compromisos anuales (Departamento de Seguridad Nacional, Gobierno de España)
} 
sociedad hegemónica vislumbrando dicotomías en lugar de focalizarse en las relaciones que comprenden.

La importancia radica, por tanto, en dar visibilidad al tratamiento, desde la construcción de categorías, de la "población extranjera" en los medios que se traslada como el discurso dominante y "común".

\section{Metodología}

La investigación parte de los métodos cualitativos de la Antropología Social y Cultural, pero al tratar la cuantificación de la "población extranjera", tanto numérica como porcentualmente, no podemos olvidar el carácter cuantitativo respecto a términos recurrentes y sujetos nombrados que también serán "contados" puesto que las migraciones son un fenómeno que parece suponer constante "contabilidad".

Esta triangulación nos permite huir, en cierta medida, del reduccionismo epistémico y metódico puesto que no hemos tratado sólo documentos oficiales como las Notas de Prensa y documentos periodísticos sino que beberemos asimismo de otros saberes no necesariamente normativos como los conformados por los emisores y receptores y que también son (re)presentados en la investigación en curso para así hallar los significados de las prácticas desde procesos de co-interpretación de discursos mediáticos entendidos como "consagrados", "legítimos" y, con ello, "normativos".

Nuestro interés se centra en la utilización de teorías psicosociales, como las relativas a las representaciones sociales, para comprender la complejidad de los procesos sociales en la construcción de discursos que producen, y también reproducen, las prácticas sociales cotidianas construyendo, a su vez, las identidades sociales, las relaciones de pertenencia a un grupo y que provocan la diferenciación con los demás. Asimismo, traen a colación cuestiones de poder, desigualdad y racismo en relación con el discurso y los fenómenos de las migraciones. Se construyen las diferencias con los "otros" desde el "nosotros" dando lugar a desigualdades sociales de diversa índole (Van Dijk, 1999: 33).

En cuanto al grupo social de interés para nuestra metodología, la investigación pretende considerar varios agentes; quienes generan las "Notas de Prensa" como son los miembros del Instituto Nacional de Estadística incluyendo tanto al equipo del Gabinete de Prensa como al de Estadística sin olvidar el departamento de Difusión Mediática. 
Asimismo, se ha tenido en consideración a los periodistas que redactan las "noticias" en relación con el fenómeno migratorio. La "población extranjera" será a posteriori entrevistada para conocer la representación de la que forma parte. Tanto ella como la población nacional serán consideradas como agentes activos. Así, en torno a los sujetos, se hará alusión a la idea de grupismo trasladado en los medios informativos pues supone un acto de homogeneización, generalización y naturalización de categorías como expondría Bañón Hernández (2014) en torno a la mención de las personas emigradas que no constituyen, sin embargo, un colectivo homogéneo puesto que esto supondría la esencialización a la que hacíamos mención.

Debemos considerar, partiendo de investigaciones anteriores (aunque diacrónicas) y en este primer escalón, el análisis exhaustivo de las Notas de Prensa, y también de las noticias periodísticas en cuanto a su estructura (título, titulares, apartados, tablas y gráficos), la evolución, un estudio de los términos utilizados, sujetos (poblaciones) nombrados y la dedicación (extensión), puesto que se observan ciertas "evidencias" de "lo noticioso" que desvelan algunas representaciones del fenómeno y de los sujetos de las migraciones. Por tanto, hemos considerado de interés destacar cómo se cuentan las migraciones en términos de espacio dedicado a tres grupos de poblaciones diferentes que se toman en consideración en las estadísticas padronales del Instituto Nacional de Estadística: la población nacional, la población extranjera y la población total. De esta manera, prestar atención a la extranjerización debida al relevante papel que tiene la "población extranjera" en las fuentes de información para así ver la conformación del "nos-otros" desde los "otros" que es una manera de diferenciar que genera, a su vez, desigualdad, tratamiento discriminatorio de los otros por parte de la población nativa y la difusión de estereotipos, prejuicios e ideas racistas (Van Dijk, 1999). Es una autopresentación positiva del grupo dominante a la vez que se da una heteropresentación negativa de los grupos dominados, una polarización del "nosotros" y del "ellos" que caracteriza las representaciones sociales compartidas.

\section{Evidencias}

Como punto de partida, hemos considerando estudios previos (Castillo Fernández y García Castaño, 2018) y, por ello, hemos prestado atención a cómo se cuentan las migraciones en términos de espacio 
dedicado a tres grupos de poblaciones diferentes que se toman en consideración en las estadísticas padronales del Instituto Nacional de Estadística. Asimismo, cabe hacer mención a los titulares que encabezan dichas Notas; sin olvidar los términos recurrentes que aparecen en dichos documentos. Con ello, hemos podido observar un tratamiento extranjerizante, pues es la "población extranjera" la que aparece en primer término reflejándose así una construcción del "nosotros" desde los "otros". Otros que son parte del fenómeno de las migraciones y que, parece, generan un problema, el "problema de la inmigración" desde la clasificación que construye, a su vez, diferencia.

Hemos comenzando construyendo un corpus de materiales a analizar a partir de un total de 17 Notas de Prensa (ver Tabla 1) que registran los años comprendidos entre 2002 hasta 2017. Con el texto íntegro de todas ellas hemos trabajado para analizar qué se dice, sobre quién se habla y cómo se dice.

Tabla 1. Titulares de las Notas de Prensa

\begin{tabular}{|c|c|c|c|}
\hline Fecha & Título & Titular 1 & Titular 2 \\
\hline $05 / 08 / 2003$ & $\begin{array}{l}\text { Explotación } \\
\text { Estadística. } 2002\end{array}$ & $\begin{array}{l}\text { Los extranjeros } \\
\text { concentran... }\end{array}$ & $\begin{array}{l}\text { El número de } \\
\text { extranjeros... }\end{array}$ \\
\hline $30 / 03 / 2004$ & $\begin{array}{l}\text { Explotación } \\
\text { Estadística. } 2003\end{array}$ & $\begin{array}{l}\text { Los extranjeros } \\
\text { suponen... }\end{array}$ & \\
\hline $27 / 04 / 2005$ & $\begin{array}{l}\text { Avance. } 2005 . \\
\text { Provisionales }\end{array}$ & $\begin{array}{l}\text { La población } \\
\text { residente en } \\
\text { España... }\end{array}$ & $\begin{array}{l}\text { El número de } \\
\text { extranjeros... }\end{array}$ \\
\hline $17 / 01 / 2006$ & $\begin{array}{l}\text { Explotación } \\
\text { Estadística. } 2006 . \\
\text { Definitivos }\end{array}$ & $\begin{array}{l}\text { La población } \\
\text { residente en } \\
\text { España... }\end{array}$ & $\begin{array}{l}\text { El número de } \\
\text { extranjeros... }\end{array}$ \\
\hline $25 / 07 / 2006$ & $\begin{array}{l}\text { Avance. } 2006 . \\
\text { Provisionales }\end{array}$ & $\begin{array}{l}\text { La población } \\
\text { empadronada en } \\
\text { España... }\end{array}$ & $\begin{array}{l}\text { El número de extranjeros } \\
\text { empadronados... }\end{array}$ \\
\hline $01 / 03 / 2007$ & $\begin{array}{l}\text { Explotación } \\
\text { Estadística. } 2006 . \\
\text { Definitivos }\end{array}$ & $\begin{array}{l}\text { La población } \\
\text { residente en } \\
\text { España... }\end{array}$ & $\begin{array}{l}\text { El número de } \\
\text { extranjeros... }\end{array}$ \\
\hline $11 / 06 / 2007$ & $\begin{array}{l}\text { Avance. } 2007 . \\
\text { Provisionales }\end{array}$ & $\begin{array}{l}\text { La población } \\
\text { empadronada en } \\
\text { España... }\end{array}$ & $\begin{array}{l}\text { El número de extranjeros } \\
\text { empadronados...,... son } \\
\text { comunitarios }\end{array}$ \\
\hline
\end{tabular}




\begin{tabular}{|c|c|c|c|}
\hline Fecha & Título & Titular 1 & Titular 2 \\
\hline $20 / 06 / 2008$ & $\begin{array}{l}\text { Avance. } 2008 . \\
\text { Provisionales }\end{array}$ & $\begin{array}{l}\text { La población } \\
\text { empadronada en } \\
\text { España... }\end{array}$ & $\begin{array}{l}\text { El número de extranjeros } \\
\text { empadronados..., ... son } \\
\text { ciudadanos de la UE }\end{array}$ \\
\hline $03 / 06 / 2009$ & $\begin{array}{l}\text { Avance. } 2009 . \\
\text { Provisionales }\end{array}$ & $\begin{array}{l}\text { La población } \\
\text { empadronada en } \\
\text { España... }\end{array}$ & $\begin{array}{l}\text { El número de extranjeros } \\
\text { empadronados..., ... son } \\
\text { ciudadanos de la UE }\end{array}$ \\
\hline $29 / 04 / 2010$ & $\begin{array}{l}\text { Avance. } 2010 . \\
\text { Provisionales }\end{array}$ & $\begin{array}{l}\text { La población } \\
\text { empadronada en } \\
\text { España... }\end{array}$ & $\begin{array}{l}\text { El número de extranjeros } \\
\text { empadronados..., ... son } \\
\text { ciudadanos de la UE }\end{array}$ \\
\hline $04 / 04 / 2011$ & $\begin{array}{l}\text { Avance. } 2011 . \\
\text { Provisionales }\end{array}$ & $\begin{array}{l}\text { La población } \\
\text { empadronada en } \\
\text { España... }\end{array}$ & $\begin{array}{l}\text { El número de extranjeros } \\
\text { empadronados...,... son } \\
\text { ciudadanos de la UE }\end{array}$ \\
\hline $19 / 04 / 2012$ & $\begin{array}{l}\text { Avance de la } \\
\text { explotación } \\
\text { estadística. } 2012 . \\
\text { Provisionales }\end{array}$ & $\begin{array}{l}\text { La población } \\
\text { empadronada en } \\
\text { España... }\end{array}$ & $\begin{array}{l}\text { El número de } \\
\text { extranjeros...,... son } \\
\text { ciudadanos de la UE }\end{array}$ \\
\hline $22 / 04 / 2013$ & $\begin{array}{l}\text { Avance de la } \\
\text { estadística. } 2013 . \\
\text { Provisionales }\end{array}$ & $\begin{array}{l}\text { La población } \\
\text { empadronada en } \\
\text { España... }\end{array}$ & $\begin{array}{l}\text { El número de extranjeros } \\
\text { inscritos..., ... son } \\
\text { ciudadanos de la UE }\end{array}$ \\
\hline $22 / 04 / 2014$ & $\begin{array}{l}\text { Avance de la } \\
\text { estadística. } 2014 . \\
\text { Provisionales }\end{array}$ & $\begin{array}{l}\text { La población inscrita } \\
\text { en el Padrón } \\
\text { Continuo... }\end{array}$ & $\begin{array}{l}\text { En } 2013 \text {, el número de } \\
\text { extranjeros inscritos... }\end{array}$ \\
\hline $21 / 04 / 2015$ & $\begin{array}{l}\text { Avance de la } \\
\text { estadística. } 2015 . \\
\text { Provisionales }\end{array}$ & $\begin{array}{l}\text { La población inscrita } \\
\text { en España en el } \\
\text { Padrón Continuo... }\end{array}$ & $\begin{array}{l}\text { En 2014, el número de } \\
\text { españoles inscritos... el } \\
\text { número de extranjeros... }\end{array}$ \\
\hline $28 / 04 / 2016$ & $\begin{array}{l}\text { Avance de la } \\
\text { estadística. } 2016 . \\
\text { Provisionales }\end{array}$ & $\begin{array}{l}\text { La población inscrita } \\
\text { en España en el } \\
\text { Padrón Continuo... }\end{array}$ & $\begin{array}{l}\text { En } 2015 \text {, el número de } \\
\text { españoles inscritos... el } \\
\text { número de extranjeros... }\end{array}$ \\
\hline $26 / 04 / 2017$ & $\begin{array}{l}\text { Avance de la } \\
\text { estadística. } 2017 . \\
\text { Provisionales }\end{array}$ & $\begin{array}{l}\text { La población inscrita } \\
\text { en España en el } \\
\text { Padrón Continuo... }\end{array}$ & $\begin{array}{l}\text { Del total de población, .... } \\
\text { son de nacionalidad } \\
\text { española y ... son } \\
\text { extranjeros }\end{array}$ \\
\hline
\end{tabular}

Fuente: Elaboración propia a partir de los datos del Instituto Nacional de Estadística

Un primer dato observable del material analizado es la referencia constante en las citadas Notas de Prensa a una tipología de sujetos que pueden ser agrupados de la siguiente manera: "población en general", 
"población española" y "población extranjera". En relación con ello hemos tratado de representar en el Gráfico 1 el espacio que ocupa en cada Nota de Prensa la mención de cada uno de estos grupos de personas. Como puede verse en el citado Gráfico 1, la mención más reiterada es para el grupo "población extranjera" y ello a pesar de que cuantitativamente es el grupo más pequeño (puede variar entre años de un $4 \%$ a un $12 \%$ de la "población general").

Gráfico 1. Distribución del espacio dedicado en cada Nota de Prensa a tres grupos de población diferentes

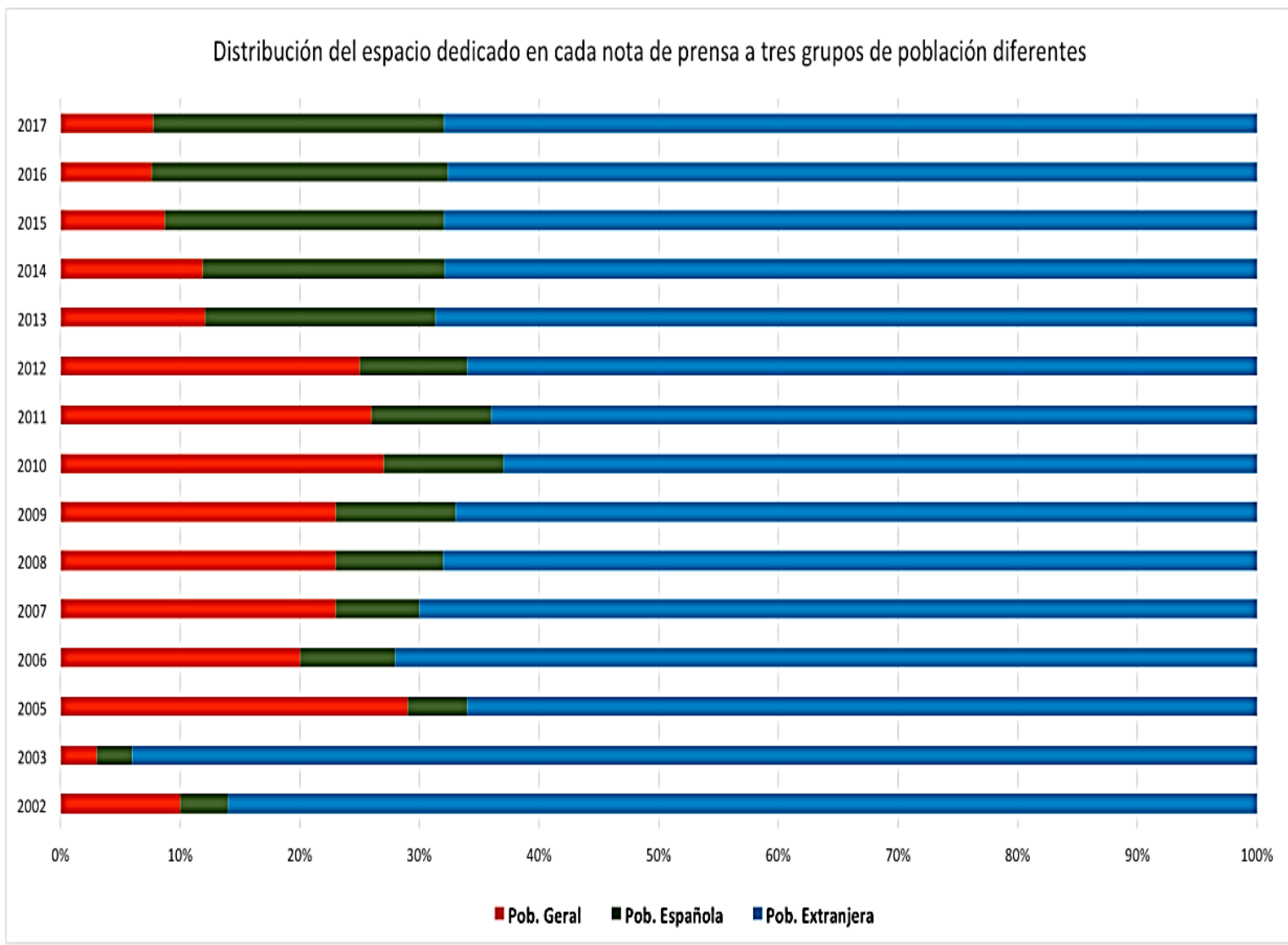

Fuente: Elaboración propia a partir de los datos del Instituto Nacional de Estadística

Complementario a este Gráfico 1 es la Tabla 2 que nos permite detallar la mención que se hace de grupo de personas (términos que nosotros indicamos como poblacionales). En esta Tabla 2 se puede ver de nuevo que el término que podríamos mostrar como más citado en primer lugar en todas las Notas de Prensa es el de "extranjeros". 
Tabla 2. Sujetos nombrados en las Notas de Prensa del INE

\begin{tabular}{|c|c|c|c|}
\hline Año & Primer término & Segundo término & $\begin{array}{l}\text { Tercer } \\
\text { Término }\end{array}$ \\
\hline 2002 & Extranjeros & Empadronados & Inscritos \\
\hline 2003 & Extranjeros & Inscritos & Empadronados \\
\hline 2005 & Extranjeros & Empadronados & Españoles \\
\hline 2006 & Extranjeros & Empadronados & $\begin{array}{l}\text { Extranjeros no } \\
\text { comunitarios }\end{array}$ \\
\hline 2007 & Extranjeros & Ciudadanos & Empadronados \\
\hline 2008 & Extranjeros & Ciudadanos & Españoles \\
\hline 2009 & Extranjeros & Ciudadanos & Españoles \\
\hline 2010 & Extranjeros & Ciudadanos & Españoles \\
\hline 2011 & Extranjeros & Ciudadanos & Españoles \\
\hline 2012 & Extranjeros & Españoles & Ciudadanos \\
\hline 2013 & Extranjeros & Españoles & Ciudadanos \\
\hline 2014 & Extranjeros & Inscritos & Españoles \\
\hline 2015 & Extranjeros & Inscritos & Españoles \\
\hline 2016 & Extranjeros & Inscritos & Españoles \\
\hline 2017 & Extranjeros & Españoles & Ciudadanos \\
\hline
\end{tabular}

Fuente: Elaboración propia a partir de los datos del Instituto Nacional de Estadística

Tras la elaboración del corpus en torno a las Notas de Prensa, y en cuanto a la manera de (re)presentar a la "población extranjera" en forma de alarma social, nos gustaría poner de manifiesto otro documento a considerar que supone el análisis de las Noticias informativas publicadas tras las citadas Notas estadísticas y que reúne 
las noticias publicadas en las sección nacional de dos de los periódicos más difundidos de España, El País y El Mundo, desde el 2003 hasta 2017, años considerados previamente para el análisis exhaustivo de las Notas de Prensa publicadas por el INE. Antes de comenzar a desgranar dichas noticias, mencionar que, sirviéndonos de la plataforma que ofrece la UGR (Universidad de Granada), My news On Line (Mediatech), y utilizando "Padrón Municipal" como término de búsqueda, mencionar que no hemos localizado noticia alguna publicada en relación con, ni en El País ni en El Mundo, para el año 2012 y desde el año 2014 en adelante hasta llegar al 2017. Sí, sin embargo, para años anteriores.

Tabla 3. Titulares y Subtitulares de la sección Nacional de los periódicos: EL PAÍS (EP) y EL MUNDO (EM) - (2003-2017)

\begin{tabular}{|c|c|c|c|c|}
\hline Año & Periódico & Autor & Título & Subtítulo \\
\hline 2003 & EP & $\begin{array}{l}\text { Charo } \\
\text { Nogueira }\end{array}$ & $\begin{array}{l}\text { Los extranjeros son ya } \\
\text { dos millones en } \\
\text { España, cinco de cada } \\
100 \text { habitantes }\end{array}$ & $\begin{array}{l}\text { Los datos del INE muestran } \\
\text { que la población inmigrante } \\
\text { se ha triplicado en cuatro } \\
\text { años }\end{array}$ \\
\hline 2004 & EM & $\begin{array}{l}\text { Roberto } \\
\text { Benito }\end{array}$ & $\begin{array}{l}\text { Los inmigrantes son ya } \\
\text { el } 6,24 \% \text { de la } \\
\text { población española }\end{array}$ & $\begin{array}{l}\text { El porcentaje ha subido en } \\
\text { un año un punto y medio - } \\
\text { El padrón revela que el } 1 \text { de } \\
\text { enero de } 2003 \text { vivían en } \\
\text { España } 1,3 \text { millones de } \\
\text { extranjeros 'sin papeles' }\end{array}$ \\
\hline 2005 & EP & $\begin{array}{l}\text { Charo } \\
\text { Nogueira }\end{array}$ & $\begin{array}{l}\text { España ya alcanza los } \\
44 \text { millones de } \\
\text { habitantes, y los } \\
\text { extranjeros superan el } \\
8,4 \%\end{array}$ & $\begin{array}{l}\text { La población aumenta en un } \\
\text { solo año en } 770.000 \\
\text { personas, en su mayoría } \\
\text { inmigrantes }\end{array}$ \\
\hline 2006 & EP & $\begin{array}{l}\text { Charo } \\
\text { Nogueira }\end{array}$ & $\begin{array}{l}\text { España roza los } 44,4 \\
\text { millones de habitantes } \\
\text { tras recibir } 650.000 \\
\text { extranjeros en } 2005\end{array}$ & $\begin{array}{l}\text { Sólo } 1,1 \text { de los } 1,7 \text { millones } \\
\text { de inmigrantes que debían } \\
\text { renovar el padrón lo ha } \\
\text { hecho }\end{array}$ \\
\hline 2007 & EM & $\begin{array}{l}\text { Olga R. } \\
\text { Sanmartín }\end{array}$ & $\begin{array}{l}\text { EL RETO DE LA } \\
\text { INMIGRACION / } \\
\text { Una nueva sociedad La } \\
\text { población en España } \\
\text { supera los } 45 \text { millones }\end{array}$ & $\begin{array}{l}\text { Por primera vez se registran } \\
\text { más empadronados } \\
\text { procedentes de la Unión } \\
\text { Europea que de Suramérica } \\
\text { Asturias es la única región } \\
\text { que pierde residentes }\end{array}$ \\
\hline
\end{tabular}




\begin{tabular}{|c|c|c|c|c|}
\hline Año & Periódico & Autor & Título & Subtítulo \\
\hline & & & $\begin{array}{l}\text { de habitantes, con casi } \\
\text { un } 10 \% \text { de extranjeros. }\end{array}$ & $\begin{array}{l}\text { mientras la Comunidad } \\
\text { Valenciana gana } 68.000\end{array}$ \\
\hline \multirow[t]{2}{*}{2008} & EM & $\begin{array}{l}\text { Pilar } \\
\text { Ortega }\end{array}$ & $\begin{array}{l}\text { Ocho de cada } 10 \\
\text { empadronados nuevos } \\
\text { en España son } \\
\text { extranjeros. }\end{array}$ & $\begin{array}{l}\text { Los rumanos desbancan a } \\
\text { los marroquíes y son ya el } \\
\text { colectivo con mayor } \\
\text { presencia / En Baleares, el } \\
20 \% \text { de la población es de } \\
\text { fuera }\end{array}$ \\
\hline & $\mathrm{EP}$ & $\begin{array}{l}\text { Tomás } \\
\text { Bárbulo }\end{array}$ & & \\
\hline \multirow[t]{2}{*}{2009} & EM & $\begin{array}{l}\text { Olga R. } \\
\text { Sanmartín }\end{array}$ & $\begin{array}{l}\text { La desaceleración } \\
\text { migratoria }\end{array}$ & $\begin{array}{l}\text { El Padrón experimenta la } \\
\text { crecida de extranjeros más } \\
\text { baja de la década }\end{array}$ \\
\hline & EP & N.J & $\begin{array}{l}\text { España tiene ya cerca } \\
\text { de } 47 \text { millones de } \\
\text { habitantes }\end{array}$ & \\
\hline \multirow[t]{2}{*}{2010} & EM & $\begin{array}{l}\text { Guillermo } \\
\text { Santa- } \\
\text { Olalla }\end{array}$ & $\begin{array}{l}\text { La afluencia de } \\
\text { inmigrantes se frenó en } \\
2009\end{array}$ & $\begin{array}{l}\text { El número de foráneos en } \\
\text { España crece tres veces más } \\
\text { que el total de la población }\end{array}$ \\
\hline & EP & & $\begin{array}{l}\text { Los latinoamericanos } \\
\text { inician el camino de } \\
\text { vuelta a casa }\end{array}$ & $\begin{array}{l}\text { Desciende el número de } \\
\text { inmigrantes de Ecuador, } \\
\text { Bolivia o Argentina - Siguen } \\
\text { creciendo rumanos y } \\
\text { marroquíes }\end{array}$ \\
\hline 2011 & $\overline{E M}$ & $\begin{array}{l}\text { Pedro } \\
\text { Simón }\end{array}$ & $\begin{array}{l}\text { Crecen los españoles, } \\
\text { bajan los extranjeros }\end{array}$ & $\begin{array}{l}\text { La Oficina del Censo } \\
\text { detecta un sospechoso } \\
\text { aumento de residentes en } \\
241 \text { municipios }\end{array}$ \\
\hline \multicolumn{5}{|l|}{2012} \\
\hline 2013 & EP & Jaime Prats & $\begin{array}{l}\text { España ya no es El } \\
\text { Dorado }\end{array}$ & $\begin{array}{l}\text { La salida de extranjeros } \\
\text { reduce el padrón a } \\
47.059 .788 \text { habitantes La } \\
\text { población cae por primera } \\
\text { vez desde que hay registros }\end{array}$ \\
\hline \multicolumn{5}{|l|}{2014} \\
\hline \multicolumn{5}{|l|}{2015} \\
\hline 2016 & & & & \\
\hline
\end{tabular}




\begin{tabular}{|l|l|l|l|l|}
\hline Año & Periódico & Autor & Título & Subtítulo \\
\hline 2017 & & & & \\
\hline
\end{tabular}

Fuente: Elaboración propia a partir de los titulares y subtitulares de las noticias correspondientes a los periódicos EL PAÍS y EL MUNDO en los años citados

En esta primera toma de contacto, puede apreciarse como la representación mediática de la "población extranjera" se ve reflejada, sobre todo y una vez más, como ocurría en las Notas de Prensa ya analizadas, en términos de "Extranjeros". Sin embargo, ya en los medios, también se muestra en términos de "Inmigrantes". A nivel de "contabilidad", el término "Extranjeros" sigue teniendo mayor relevancia en los títulos y subtítulos que encabezan las noticias pues aparece en nueve ocasiones mientras que "Inmigrantes", en cinco. Asimismo, podemos observar que los considerados "población extranjera" (también denominados "extranjeros", "foráneos", "población inmigrante", "de fuera") se consideran en términos de "inmigrantes" indistintamente como ocurre en el ejemplo del primer año analizado, 2003.

Destacamos la comparativa que se lleva a cabo con "España" o la "población nacional" pero también con la "población total"; y resulta en términos de cuantificación e intensificación, así como de cantidades, tanto a nivel nominal como porcentual, que desvelan, en su mayoría, "aumentos", "multiplicaciones", "triplicaciones" de esta población no nacional. En ocasiones, descensos de unas nacionalidades frente a otras.

También aparecen conceptos presentados en términos de "irregularidad" en cuanto a la citada estrategia mediática de contar personas y que fundamentan esa idea de "contabilidad", y también "control", como son los términos: "sin papeles", entre otros, que pasaremos a investigar en estudios a posteriori pero siempre teniéndolos presentes de manera diacrónica en nuestro análisis. 


\section{Conclusiones y reflexiones}

En términos de "transformación", se ha consolidado, como dijera López-Escobar et al (1996: 9): "Un método empírico para mostrar cómo los medios de difusión consiguen transferir a sus audiencias las listas jerarquizadoras de los temas o problemas más destacados para la sociedad". Por su parte, como diría Cohen (1963), son los medios los que dirigen la atención hacia qué pensar y hacia qué prestar atención. Según Noam Chomsky (1988), y a nuestro parecer, esta agenda que consideraremos agenda nacional es la que conforma una "alianza tácita" que existe entre quien produce información, el gobierno del país (Occidental en el caso que nos compete) y los medios de comunicación con el fin de comunicar a los espectadores, oyentes o lectores de un determinado medio, sólo lo que interesa a dicho "cuarto poder" para así ocultar al máximo lo que puede resultar peligroso o perjudicial para la estabilidad que ellos creen adecuada para su país, en aras de su considerada "seguridad nacional". Esto supone, a su vez, la propia organización de la noticia, de los espacios dedicados a la misma entre otras variables como la canalización de la información, su redimensionamiento y su divulgación.

La denominada agenda-setting, por ende, supone identificar los asuntos más importantes para los medios informativos, que sostienen unas tendencias y que no suelen ser "parciales" aunque si en sus "realidades". Asuntos que incluyen o excluyen, a su vez, sujetos que funcionan como endogrupo o exogrupo. El énfasis constante en ciertos temas por parte de los medios informativos tiende a crear preocupación sobre ellos además de sobre los sujetos considerados en tales asuntos. La minoría extranjera respecto a la población general ocupa, sin embargo, un lugar "privilegiado" en la agenda mediática como hemos podido ver tanto en las Notas de Prensa como en las Noticias que se elaboran tras las anteriormente citadas. Informes que en función de la intensidad a la que hacen alusión, trasladan cierta alarma social que es aún más llamativa en los medios de comunicación de masas por lo que el fenómeno migratorio es visto como el "problema de la inmigración" puesto que la "población nacional" se ve afectada por el aumento de "población extranjera" "sin papeles" además de que se "detecta un sospechoso aumento de residentes" (sugiere descontrol, desorden), que no renuevan el Padrón Municipal (sugiere 
culpabilidad) y que, por tanto, no aparecen registrados (sugiere inconmensurabilidad).

En torno al tema de las representaciones sociales, el contexto se va construyendo en sus significados y a partir de las relaciones sociales que llevan a cabo los sujetos. Sujetos que son activos puesto que las fabrican, las transforman, las reconstruyen y las transmiten. De esta manera, destacar la importancia que recae sobre el proceso dialéctico y el carácter social porque estos son elaborados y compartidos por un grupo social con el fin de clasificar un "objeto", también social, para así incorporarlo a su realidad cotidiana (Berger y Lukcman, 1986). Las representaciones se transforman en actos y, por ende, en contextos en los que se interrelacionan los sujetos con las repercusiones que ello conlleva. Son representaciones sociales que marcan pautas de relaciones que se traducen en comportamientos (Moscovici, 1984). Los sujetos son los que llevan en sí las representaciones del imaginario social, del marco mental (Jodelet, 1988) de referencia que funciona como "legítimo" y que ordena los sujetos, miembros estos de los grupos sociales que se tratan como homogéneos. Así, las representaciones ostentan significados y, con ello, conforman las categorías que "ordenan", clasifican. Se trata de constructos que se generan a medida que ocurre la interacción social en los contextos determinados de estudio. Las notas de prensa y las noticias son sólo dos formas de representar la migración desde categorías mutuamente excluyentes que no se crean, sin embargo, sin incluirse.

Es notorio como, en términos de identidad nacional, el vocabulario relacionado con la procedencia nos lleva a utilizar categorías mutuamente excluyentes. Siendo así, en términos de "legitimidad", el discurso, tanto el presentado en las propias Notas de Prensa como el que luego aparece en los artículos periodísticos, se legitima gracias a que procede de una fuente estadística oficial como es el INE y/o como son EL PAÍS y EL MUNDO en el caso de los periódicos considerados de periodicidad diaria y tirada nacional. Tomando en cuenta que estas fuentes informativas difunden la información que es relevante para la sociedad, habría que plantearse qué información lo es, por qué, desde quién y para quién. Se trata de una confluencia de intereses y decisiones que se ejercen desde el "nosotros", que somos quienes construimos a los "otros" de manera esencializante, así como la consideración de todo el 
proceso que conlleva el conformar tales categorías de identificación social. Por ello, y en relación directa con el fenómeno migratorio en España, es importante hacer hincapié en la importancia de este en los medios de comunicación de masas pues ha ocupado un espacio muy importante durante años en las agendas; las que han venido conformando y estructurando el imaginario colectivo de los españoles sobre las características de dicho fenómeno y su visibilización (Martínez Granados, 2015b). Por ello, merece mención la teoría del establecimiento de la agenda, cuya relevancia temática se traslada desde los medios al público dando lugar postula la gran influencia que tienen los medios de comunicación de masas sobre el público, lo que termina siendo una única agenda que sostiene un discurso común y "normalizado" desde la entidad que lo emite que, considerando la prensa escrita nacional, será la población considerada como tal, nacional.

El impacto de la "noticia" existe únicamente si, valga la redundancia, es noticioso por lo que destacamos los datos de la tabla 3 que presentan esa intensidad que hace hincapié en la variabilidad de población nacional respecto a esa recurrencia del aumento de "población extranjera". Es importante cómo los medios atienden a la percepción que el público tiene respecto a los asuntos relacionados con el fenómeno migratorio, siquiera sin mencionarlo en las Notas de Prensa mientras que los medios de comunicación como son EL PAÍS y EL MUNDO sí desvelan, al menos en la terminología, la raíz del término que alude a la migración. Visibilizar estos datos es relevante pues las posibilidades de discernir la información que los consumidores (que también somos agentes activos) recibimos dependen de la restricción que los medios masivos llevan a cabo puesto que nos llegará, en última instancia, lo que resulte de interés para las entidades que lo emiten. En este caso, el Instituto Nacional de Estadística y los periódicos de difusión masiva estudiados. Ese "otros" desde ese "nosotros" que se presenta de manera incluyente o excluyente en términos de salvaguarda de la "seguridad nacional".

En torno a las citadas repercusiones de los discursos presentados, merece resaltar que a partir de ese producto "noticia", que sería la Nota de Prensa, la información pasa a hacerse "noticiable" en forma de, valga la redundancia, "noticias" que, ya insertas en los medios de comunicación de masas, trasladan discursos que provocan efectos, $y$ 
afectos, en los "consumidores". En definitiva, una forma de generar inquietud sobre la población que no es nacional desde los medios de comunicación, ya sean los de organismos oficiales como es aquí el INE (Instituto Nacional de Estadística) y sus Notas de Prensa como también las noticias que se publican en los periódicos tras estas Notas.

La importancia de la investigación reside en la visibilidad y el análisis de la construcción de la diferencia que construye, a su vez, desigualdad. Se puede apreciar que se cuentan diversidades al mismo tiempo que se controlan tales diferencias. Representaciones mediáticas que desvelan una manera de contar que supone, al mismo tiempo, controlar. A posteriori, siendo parte de un estudio más amplio, se utilizará en menor medida, la etnografía virtual para conocer los conceptos claves a nivel de terminología que se repiten con frecuencia en las redes sociales, sobre todo en las opiniones de periódicos digitales para llevarlos así hacia un estudio comparativo. La difusión de la citada contabilidad conlleva repercusiones que se difunden en forma de desigualdad y que "ordenan" a la sociedad en términos de inclusión (nosotros) y exclusión (otros) en función de los intereses de quienes cuentan las migraciones considerando qué, y para quién, es "noticia".

\section{Bibliografía}

Bañón Hernández, A. M. (2014). Medios de comunicación e inmigración. Aproximación a una línea de investigación consolidada. En C. Blanco Fernández de Valderrama (Ed.), Movilidad humana y diversidad social en un contexto de crisis económica internacional (Primera, pp. 111-135). Madrid: Trotta.

Bañón Hernández, A. M., Benítez Eyzaguirre, L., \& Granados Martínez, A. (2012). El discurso radiofónico y audiovisual sobre los procesos migratorios. Estado de la cuestión. En VII Congreso Migraciones Internacionales en España: movilidad humana y diversidad social (11-13 de abril) (pp. 3120-3139). inproceedings, Bilbao: Universidad País Vasco.

Castillo Fernández, A. y García Castaño, F.J. (2017). Las estadísticas padronales del INE y su relación con las migraciones. El caso de sus Notas de Prensa. El fin de un modelo de política $\left(2^{\mathrm{a}}\right.$ edición, ampliada). Revista Latina de Comunicación Social. 
Libro Colectivo del IX Congreso Internacional Latina de Comunicación Social.

Chomsky, N. y Herman, E.S. (1988). Los guardianes de la libertad. Austral

Cohen, B.C. (1963). The Press and Foreign Policy. Princeton University Press.

García Castaño, F. J., Granados Martínez, A. y Fuente Miranda, B. de la. (2009). Inmigrantes y extranjeros en la prensa en España y sus representaciones a partir de los datos estadísticos. Tercer Milenio. Revista de Comunicaciones, Periodismo y Ciencias Sociales, 13(16), 26-46.

García Castaño, F. J., Granados Martínez, A. y Fuente Miranda, B. de la. (2008). La población inmigrante extranjera, el padrón municipal y su reflejo en la prensa. En A. M. Bañon \& J. Fornieles (Eds.), Manual sobre comunicación e inmigración (pp. 255-280). incollection, San Sebastián: Gakoa

Granados Martínez, A., Fernández Echeverría, J. y García Castaño, F. J. (2015). La mirada del Instituto Nacional de Estadística y la prensa escrita sobre la población extranjera y la población inmigrante. In F. J. García Castaño, A. Megías Megías, \& J. Ortega Torres (Eds.), Actas del VIII Congreso sobre Migraciones Internacionales en España (Granada, 16-18 de septiembre de 2015) (p. S23/80-S23/97). Granada: Instituto de Migraciones.

Instituto Nacional de Estadística. Notas de Prensa. Explotación Estadística del Padrón Municipal de Habitantes. España. INE (2002-2017)

Jodelet, D. (1988). La representación social: fenómenos, concepto y teoría. En Moscovici, S (Eds.). Psicología social II. Pensamiento y vida social. Barcelona: Paidós

Lakoff, G. (2004). No pienses en un elefante. Lenguaje y debate político. Foro Complutense. Universidad Complutense de Madrid.

López-Escobar, Llamas, J.P (1996). Agenda-setting: investigaciones sobre el primero y el segundo nivel. Comunicación social. Vol $\mathrm{N}^{\mathrm{o}} 1$ y 2 . Universidad de Navarra Maxwell, E.; McCombs, y Shaw, Donald, L. (1972). The agendaSetting function of mass media. The Public Opinion Quarterly. 
Vol. 36, No 2 (Summer, 1972), pp. 176-187. Oxford University Press. En American Association for Public Opinion Research. Moscovici, S. (1984). Introducción a la psicología social. Barcelona: Planeta.

My news On Line (Mediatech), Biblioteca UGR

https://biblioteca.ugr.es/pages/biblioteca_electronica/bases_datos/ my_news_online

Prensky, M. (2010). Digital natives, digital immigrants. Nativos e inmigrantes digitales. Institución Educativa SEK. Cuadernos SEK 2.0.

Santamaría, E. (2002). La incógnita del extraño. Una aproximación a la significación sociológica de la "inmigración no comunitaria". Anthropos, 2002, Barcelona.

Van Dijk, T.A. (1999). Análisis crítico del discurso. Anthropos. Barcelona. 


\title{
Espacios de paz en las trayectorias migratorias de las personas de África subsaharianas que llegan a Melilla
}

\author{
Rocío González Rey \\ Universidad de Granada, España
}

\section{Resumen}

Promover, cuidar y mimar las paces implica, entre otras cosas, visibilizar las gestiones pacíficas de los conflictos. Son muchos los que las personas subsaharianass se encuentran en sus rutas migratorias, pero ¿cuáles son los espacios de paz? A través de sus propias voces conocemos en el presente texto algunos de estos momentos donde la solidaridad, la cooperación y las redes de apoyo juegan un papel determinante en sus trayectorias. Una necesaria promoción de las paces en un contexto mediático donde las violencias, los estereotipos y la información sesgada marcan el imaginario colectivo con ideas sobre las personas que se mueven como invasoras y salvajes, deshumanizándolas y llevando a la opinión pública a retener imágenes de pateras y saltos a las vallas sin tener en cuenta la verdadera complejidad de las realidades migratorias y, por supuesto, silenciando las vidas de estas personas y escondiendo las resistencias y formas de cooperación pacífica que hacen posibles las rutas. Ésta es una investigación donde ponemos la vida en el centro.

Palabras clave: personas migrantes, paz imperfecta, gestión pacífica, solidaridad, violencia. 


\section{Introducción}

— L PRESENTE texto responde a la investigación que se llevó a cabo como Trabajo de Fin de Máster en Cultura de Paz, Conflictos, Educación y Derechos Humanos del Instituto de la Paz y los Conflictos de la Universidad de Granada. Nace de un doble interés, académico y personal, y tiene como finalidad rescatar los espacios de paz que se construyen a lo largo de las trayectorias migratorias de las personas migrantes subsaharianas ${ }^{36}$ que llegan a Melilla.

Alli sólo hay terroristas. Si los terroristas ven acercarse un vehiculo por alli, si ven un vebiculo por el desierto, lo hacen explotar. Lo explotan por los aires. Es por eso que el chófer nos deja un poco antes y nos bajamos. Andamos por el desierto. [Silencio] Tendrás sed, miedo... Te escondes. Cuando ves a los terroristas, ves que son muchos... Vas a correr rápidamente. Sólo puedes ver arena, nada más que arena... y los terroristas. (...) Es verdaderamente difícil. [Silencio]

Es muy, muy difícil.

(E. Guinea 2, 12 de junio 2015)

En general, el discurso mediático en cuanto a los movimientos migratorios está caracterizado por términos impregnados de valoraciones negativas y/o violentas, siendo avalancha, invasión, gueto, mafias, fundamentalismo, entre otros conceptos, los que abundan en los medios de comunicación españoles, deshumanizando así a las personas que se mueven. Sobre todo, cuando los medios abordan la llegada de migrantes en barcazas, saltando las vallas de Ceuta y Melilla, ocultos en dobles fondos de vehículos o, escondidos en maletas o asientos.

Los medios son agentes relevantes en cuanto a la formación de la opinión pública respecto a estos movimientos de personas, abusando de términos peyorativos y rescatando los discursos políticos más

$36 \mathrm{Me}$ refiero a sudsabarianas en lugar de subsabarianas, porque este último término lleva el prefijo sub, que significa "inferioridad", "por debajo de" o "con escasez", cuando la intención es nombrar la zona geográfica al sur del Sáhara. Es así como se denomina a Sudamérica, no a Subamérica. (Crespo, 2009). 
racistas y xenófobos, creando así en la sociedad receptora un sentimiento de miedo y rechazo, lo que se podría calificar como violencia cultural. Hay algunos estudios que demuestran que la percepción por parte de la población autóctona sobre el número de personas migrantes es mucho mayor al real. Algo que deja entrever el poder de los mensajes mediáticos sobre las migraciones, y que es significativo en cuanto a que "la verdadera avalancha procede de los discursos de responsables políticos y de determinados medios de comunicación, produciendo una hiper-visibilidad de los inmigrantes, siempre asociada a factores negativos: superpoblación, falta de empleo, saturación de servicios médicos y sociales, etc." (Ascanio, 2007: 56).

Bajo esta misma lógica mediática se impulsan los mensajes cargados de connotaciones negativas sobre los saltos de las vallas fronterizas de las comunidades autónomas de Ceuta y Melilla. Son múltiples los ejemplos de noticias donde evidenciamos la presencia de las violencias estructurales, directas y culturales en torno a la entrada de personas subsaharianas a Melilla.

La frontera no es el único punto donde la violencia es observable, puesto que las trayectorias migratorias de quienes se aventuran a salir de sus países para llegar a Europa se caracterizan por poner en riesgo sus vidas de manera constante, a lo que las instituciones españolas responden con el incremento de las expulsiones, la denegación de protección internacional y el desmantelamiento de los asentamientos de personas migrantes al otro lado de las vallas, en territorio marroquí. Esta última actuación es llevada a cabo por las autoridades marroquíes a petición de España, puesto que son varios los bosques cercanos a Nador $^{37}$ (Gurugú, Selouane, Mariouari, entre otros) en los que algunas de las mujeres, hombres, niñas y niños subsaharianos viven esperando pasar a Melilla. Así, El País recogía a mediados de febrero de 2014 las declaraciones de "fuentes policiales españolas", quienes advertían que "alrededor de 30.000 subsaharianos [estaban] asentados en Marruecos a la espera de poder entrar clandestinamente en Europa, en la mayoría de los casos a través de Ceuta y Melilla". La gran cantidad de personas en espera a la que se refiere el periódico se relaciona de nuevo con las comunes ideas de invasión y avalancha que reproducen los medios,

37 Provincia marroquí fronteriza con Melilla, separada con una triple valla y un foso que se detallarán más adelante. 
pero también con la necesidad de violencia para reprimir esta "entrada masiva" de personas.

Las escenas de violencia directa que se dan en los intentos de salto a las vallas de Melilla han sido recogidas en imágenes por diferentes organizaciones, como PRODEIN ${ }^{38}$ y llevadas ante la justicia con el objetivo de no dejar impune una violencia que acarrea la vulneración de los Derechos Humanos. Las devoluciones en caliente de las personas migrantes a territorio marroquí, las palizas, los insultos y la humillación son momentos violentos que se viven en las vallas de Melilla, perpetuadas tanto por las autoridades marroquíes como por las españolas. En contraposición, son diversos los medios de comunicación que denuncian la situación de vulnerabilidad a la que se ven expuestas las personas migrantes y la sistemática violación de sus derechos. Medios que promueven discursos antirracistas y que desarrollan proyectos periodísticos alternativos para contar la variopinta realidad africana desde las potencialidades y cotidianidades de las personas que la habitan.

En esta línea, y teniendo en cuenta que es necesario rescatar las historias de las personas que se mueven, voluntaria o involuntariamente; las causas por las que salen de sus hogares; cómo son sus trayectorias; cómo viven en países árabes de tránsito como Marruecos o Argelia; de qué manera se ven expuestos a la violencia racista institucional, estructural, directa y cultural; entre otras cuestiones arraigadas a su persona, me decanto aquí a profundizar sobre estas cuestiones para ver cómo las personas migrantes subsaharianas consiguen llegar hasta Melilla utilizando sus redes sociales, la cooperación, la solidaridad, la gestión pacífica de los conflictos, la mutua ayuda, la religión y otros factores promotores de paz. Hablamos, entonces, de la paz imperfecta propuesta por Muñoz (2001), quien defendía que "una de las tareas principales de todos los pacifistas, de todas las personas y grupos comprometidos de una u otra forma con la paz, debe ser rescatar las realidades [...] [y] reconocer todas las acciones en las cuales está presente [la paz]", resaltando así "todas las predisposiciones, actitudes y acciones individuales, subjetivas, sociales y estructurales- que en nuestros actos de hablar o expresar,

38 Asociación Pro Derechos de la Infancia, y de las personas migrantes. 
pensar, sentir y actuar estén relacionados con la paz" (Muñoz, 2004: 899).

Asimismo, es indispensable cuestionar el mediático "salto a la valla" como el único punto conflictivo y, además violento, al que hacen frente los migrantes. Es importante tener en cuenta las dificultades fronterizas, la presencia de grupos armados en diferentes zonas del norte de Malí o Mauritania, la existencia de militares en las fronteras de Argelia con Marruecos, el racismo y la xenofobia extendidos por los países árabes, entre otros aspectos conflictivos y violentos en los que se ve envuelta la persona migrante subsahariana con destino al continente europeo.

El análisis de las migraciones ha sido escasamente abordado desde el enfoque de la paz, por lo que resulta además de interesante, necesario, analizar las trayectorias migratorias desde la perspectiva pacifista y, más concretamente, desde la paz imperfecta, puesto que como herramienta teórica nos permite reconocer los espacios donde se producen regulaciones pacíficas de conflictos y donde están presentes la cooperación, la solidaridad y la ayuda mutua. Añade Sandoval (2009: 22) que "la migración indocumentada, a pesar de constituir uno de los grandes conflictos internacionales, no ha sido abordada desde las perspectivas de los estudios de la paz en su extensión y complejidad analítica".

De esta forma, y en contraposición a los discursos mediatizados más generalistas, nos acercaremos a responder a la siguiente pregunta: ¿Cómo logran llegar las personas a Melilla desde que salen de sus hogares en África subsahariana? ¿Cómo se construye la paz imperfecta que planteamos? Los espacios de paz a los que nos referimos confluyen con los conflictos e, incluso con la violencia. Se trata de espacios -tanto físicos como no físicos- donde convergen cualidades pacíficas como la solidaridad, la cooperación, la asociación, la ayuda, las redes sociales de apoyo, la organización, la gestión de los conflictos, la convivencia, la religión y la utilización del lenguaje, siempre y cuando se utilicen para satisfacer las necesidades de las personas y como promotoras de paz.

\section{Metodología}

La investigación se basa en las experiencias de las personas que se mueven, analizando sus vivencias, dinámicas y relaciones durante el 
trayecto desde sus hogares hasta llegar a la ciudad autónoma de Melilla, puesto que para comprender a quienes migran "hay que ir a la raíz, al origen, y explorar sus motivaciones" (Aldalur, 2010:19). Por su parte, Ruiz (2012: 24) apunta que "el auténtico significado de los actos es conocido, privilegiada y primariamente, por los propios actores". Por esto, partiendo de la investigación social y la metodología cualitativa, las técnicas etnográficas que se han llevado a cabo en el presente análisis son la observación participante, las entrevistas informales y las entrevistas en profundidad a informantes clave y privilegiados.

Para así llegar al objetivo general de la presente investigación: conocer la construcción de los espacios de paz en sus trayectorias migratorias.

\section{Técnicas etnográficas de recolección de datos}

El trabajo etnográfico se desarrolló durante los meses de mayo, junio y julio de 2015 en el Centro de Estancia Temporal de Inmigrantes ${ }^{39}$ (CETI) de la ciudad autónoma de Melilla ${ }^{40}$, donde conocí a los y las participantes clave y privilegiados, y en la provincia de Nador.

Se siguió una guía de entrevista para las individuales en profundidad a las personas que estaban en ese momento en el CETI- y otra guía para los informantes privilegiados -en contacto directo desde diferentes posiciones con las personas migrantes y sus realidades- ${ }^{41}$. Enriqueciendo estos testimonios con las informaciones de la observación participante.

\section{Registro del trabajo de campo}

Un total de trece entrevistas analizadas siguiendo los siguientes ejes: cooperación, solidaridad, redes sociales, ayuda mutua, convivencia, religión y la utilización del lenguaje. De éstos emanan algunas de las categorías que se detallarán en la exposición de los resultados.

\section{Perfil de los informantes.}

Son trece las entrevistadas, siendo ocho perfiles de personas subsaharianas residentes en el CETI en ese momento, y cinco perfiles

\footnotetext{
${ }^{39}$ Gestionado por el Ministerios de Empleo y Seguridad Social.

${ }^{40}$ En España hay dos Centros de Estancia Temporal de Inmigrantes situados en cada una de sus ciudades autónomas, Ceuta y Melilla.

${ }^{41}$ Todas las entrevistas se realizaron durante los meses de junio y julio de 2015.
} 
de personas con diferentes posiciones respecto a la realidad migratoria de Melilla.

Informantes clave.

El perfil común de los informantes clave es que son hombres y mujeres originarios de países de África subsaharianas que entraron a Melilla sin visado en los dos meses anteriores a las entrevistas. Seis son hombres, siendo uno de ellos de Senegal y cinco de Guinea Conakry; y dos son mujeres, una de Nigeria y otra de Costa de Marfil. Durante los meses de trabajo de campo había en el CETI 70 personas de África subsaharianas, de las cuales sólo nueve eran mujeres ${ }^{42}$. De los hombres, la mayor parte eran procedentes de Guinea Conakry.

Para respetar el anonimato de los y las participantes, presento a continuación una tabla donde se resumen algunas de las características a tener en cuenta y el nombre que se les dará de ahora en adelante.

Tabla 1. Características de los informantes clave

\begin{tabular}{|c|c|c|c|c|c|c|c|}
\hline & Edad & $\begin{array}{l}\text { Ciudad } \\
\text { y Etnia }\end{array}$ & $\begin{array}{l}\text { Religión y } \\
\text { estado } \\
\text { civil }\end{array}$ & $\begin{array}{l}\text { Estudios/ } \\
\text { Trabajo }\end{array}$ & $\begin{array}{l}\text { Países de } \\
\text { tránsito }\end{array}$ & $\begin{array}{l}\text { Duración } \\
\text { trayecto }\end{array}$ & $\begin{array}{l}\text { Forma } \\
\text { de } \\
\text { entrada }\end{array}$ \\
\hline $\begin{array}{l}\text { E. Senegal } \\
\text { (Hombre) }\end{array}$ & 18 & $\begin{array}{l}\text { Dakar } \\
\text { Wólof }\end{array}$ & $\begin{array}{l}\text { Musulmán } \\
\text { Soltero }\end{array}$ & $\begin{array}{l}\text { Estudios } \\
\text { básicos }\end{array}$ & $\begin{array}{l}\text { Malí, } \\
\text { Burkina } \\
\text { Faso, Níger, } \\
\text { Argelia, } \\
\text { Marruecos }\end{array}$ & 11 meses & $\begin{array}{l}\text { Vallas } \\
40 \\
\text { personas }\end{array}$ \\
\hline $\begin{array}{l}\text { E. Guinea } \\
1 \\
\text { (Hombre) }\end{array}$ & 25 & $\begin{array}{l}\text { Conakry } \\
\text { Susu }\end{array}$ & $\begin{array}{l}\text { Musulmán } \\
\text { Soltero }\end{array}$ & $\begin{array}{l}\text { Estudios } \\
\text { básicos } \\
\text { Vigilante }\end{array}$ & Marruecos & 3 días & $\begin{array}{l}\text { Vallas } \\
2 \\
\text { personas }\end{array}$ \\
\hline $\begin{array}{l}\text { E. Guinea } \\
2 \\
\text { (Hombre) }\end{array}$ & 19 & $\begin{array}{l}\text { Labé } \\
\text { Poeuhl }\end{array}$ & $\begin{array}{l}\text { Musulmán } \\
\text { Soltero }\end{array}$ & $\begin{array}{l}\text { Estudios en } \\
\text { Ciencias } \\
\text { Sociales }\end{array}$ & $\begin{array}{l}\text { Mauritania, } \\
\text { Argelia, } \\
\text { Marruecos }\end{array}$ & 10 meses & $\begin{array}{l}\text { Vallas } \\
\text { Solo }\end{array}$ \\
\hline $\begin{array}{l}\text { E. Guinea } \\
3 \\
\text { (Hombre) }\end{array}$ & 23 & $\begin{array}{l}\text { Kankan } \\
\text { Foresier }\end{array}$ & $\begin{array}{l}\text { Cristiano } \\
\text { Soltero }\end{array}$ & $\begin{array}{l}\text { Estudios } \\
\text { básicos } \\
\text { Conductor }\end{array}$ & $\begin{array}{l}\text { Malí, } \\
\text { Burkina } \\
\text { Faso, } \\
\text { Mauritania, }\end{array}$ & $\begin{array}{l}\text { Un año y } \\
\text { siete } \\
\text { meses }\end{array}$ & $\begin{array}{l}\text { Vallas } \\
\text { Solo }\end{array}$ \\
\hline
\end{tabular}

\footnotetext{
${ }^{42}$ Había en ese momento unas 1.200 personas en el Centro, siendo en su mayoría de Siria.
} 


\begin{tabular}{|c|c|c|c|c|c|c|c|}
\hline & Edad & $\begin{array}{l}\text { Ciudad } \\
\text { y Etnia }\end{array}$ & $\begin{array}{l}\text { Religión y } \\
\text { estado } \\
\text { civil }\end{array}$ & $\begin{array}{l}\text { Estudios/ } \\
\text { Trabajo }\end{array}$ & $\begin{array}{l}\text { Países de } \\
\text { tránsito }\end{array}$ & $\begin{array}{l}\text { Duración } \\
\text { trayecto }\end{array}$ & $\begin{array}{l}\text { Forma } \\
\text { de } \\
\text { entrada }\end{array}$ \\
\hline & & & & & $\begin{array}{l}\text { Argelia, } \\
\text { Marruecos }\end{array}$ & & \\
\hline $\begin{array}{l}\text { E. Guinea } \\
4 \\
\text { (Hombre) }\end{array}$ & 20 & $\begin{array}{l}\text { Conakry } \\
\text { Poeuhl }\end{array}$ & $\begin{array}{l}\text { Musulmán } \\
\text { Soltero }\end{array}$ & $\begin{array}{l}\text { Estudios en } \\
\text { Ciencias } \\
\text { Sociales }\end{array}$ & $\begin{array}{l}\text { Malí, } \\
\text { Argelia, } \\
\text { Marruecos }\end{array}$ & $\begin{array}{l}\text { Un año y } \\
\text { medio }\end{array}$ & $\begin{array}{l}\text { Vallas } \\
\text { Solo }\end{array}$ \\
\hline $\begin{array}{l}\text { E. Guinea } \\
5 \\
\text { (Hombre) }\end{array}$ & 28 & $\begin{array}{l}\text { Conakry } \\
\text { Malinké }\end{array}$ & $\begin{array}{l}\text { Musulmán } \\
\text { Soltero }\end{array}$ & $\begin{array}{l}\text { Matemáticas } \\
\text { e informática } \\
\text { aplicadas a la } \\
\text { Gestión } \\
\text { Futbolista }\end{array}$ & $\begin{array}{l}\text { Senegal, } \\
\text { Mauritania, } \\
\text { Argelia, } \\
\text { Marruecos }\end{array}$ & Seis meses & $\begin{array}{l}\text { Patera } \\
14 \\
\text { personas }\end{array}$ \\
\hline $\begin{array}{l}\text { E. Nigeria } \\
\text { (Mujer) }\end{array}$ & 26 & $\begin{array}{l}\text { Arbow } \\
\text { Urhobo }\end{array}$ & $\begin{array}{l}\text { Cristiana } \\
\text { Casada } \\
\text { Un hijo }\end{array}$ & $\begin{array}{l}\text { Estudios } \\
\text { básicos } \\
\text { Prostitución }\end{array}$ & $\begin{array}{l}\text { Níger, Malí, } \\
\text { Argelia, } \\
\text { Marruecos }\end{array}$ & $\begin{array}{l}\text { Dos años } \\
\text { y medio }\end{array}$ & $\begin{array}{l}\text { Puesto } \\
\text { frontera } \\
\text { Sola }\end{array}$ \\
\hline $\begin{array}{l}\text { E. Costa } \\
\text { de Marfil } \\
\text { (Mujer) }\end{array}$ & 35 & $\begin{array}{l}\text { Abiyán } \\
\text { Baulé }\end{array}$ & $\begin{array}{l}\text { Cristiana } \\
\text { Soltera } \\
\text { Una hija }\end{array}$ & $\begin{array}{l}\text { Estudios en } \\
\text { Secretaría y } \\
\text { Auxiliar de } \\
\text { Enfermería }\end{array}$ & $\begin{array}{l}\text { Ghana, } \\
\text { Benín, Malí, } \\
\text { Argelia, } \\
\text { Marruecos }\end{array}$ & 11 meses & $\begin{array}{l}\text { Puesto } \\
\text { frontera } \\
\text { Sola }\end{array}$ \\
\hline
\end{tabular}

Informantes privilegiados.

Por sus trayectorias profesionales y personales, cada uno de los cinco informantes aporta a la investigación una información muy útil para ser contrastada y complementada con los datos emergentes de las entrevistas con las y los participantes clave. Tienen contacto directo con las personas migrantes, pero desde perspectivas y posiciones muy diferenciadas.

Jesús Blasco de Avellaneda es periodista freelance y fixer de la frontera sur desde hace más de 17 años; José Palazón es activista de PRODEIN desde hace más de 20 años; Esteban Velázquez, responsable de la Delegación de Migraciones de Nador en el momento de la investigación; Carlos Montero es el director del CETI; E. Cruz Roja es 
enfermera de Cruz Roja en emergencias y dentro del CETI (se omite su nombre por petición propia).

\section{La paz imperfecta y las trayectorias migratorias subsaharianas}

Solidaridad, cooperación, ayuda, asociación y colectividad son términos que llevan a pensar en la paz, relacionándola con el bienestar de las personas y con las "situaciones en las que las personas gestionan sus conflictos de tal manera que se satisfacen al máximo posible sus necesidades" (Muñoz, 2004: 885). Asistimos a la presentación de dos términos que pueden parecer contrarios, pero que están presentes en la misma realidad: la paz y el conflicto. Ruiz Jiménez (2004: 150) se refiere al conflicto como aquellas "situaciones de disputa o divergencia en las que existe una contraposición de intereses, necesidades, sentimientos, objetivos, conductas, percepciones, valores y/o afectos entre individuos o grupos que definen sus metas como mutuamente incompatibles", siendo éste inherente a la naturaleza humana, en el que se pueden dar o no expresiones violentas.

De acuerdo con el movimiento de personas que abordamos, las divergencias entre los intereses de los diferentes actores están continuamente presentes, llegando incluso a la violencia, como la ejercida por las autoridades marroquíes o los terroristas. La violencia es entendida de forma genérica por Muñoz y Jiménez (2004: 1159) como "todo aquello que, siendo evitable, impide, obstaculiza o no facilita el desarrollo humano, el crecimiento de las capacidades potenciales". Son estos autores quienes hacen referencia a la violencia estructural, directa, cultural y simbólica.

La violencia estructural se refiere a los procesos en los que la acción violenta se produce a través de mediaciones estructurales $\mathrm{O}$ institucionales; la violencia directa puede ser física, psicológica o verbal (detenciones, expulsiones y agresiones); y la violencia cultural legitima y/o promueve la violencia de cualquier origen o signo.

Paz y conflicto -expresado en muchas ocasiones con violencia- están presentes en las trayectorias migratorias de las personas subsaharianas, por eso aquí vamos a focalizar la atención en las gestiones pacíficas, para lo cual desde la paz imperfecta (Muñoz, 2001) podremos hacerlas explícitas, explicarlas y darlas la relevancia que merecen, alejándonos 
de los discursos xenófobos, racistas, capitalistas, patriarcales y paternalistas.

En cuanto a las diversas formas de regulaciones pacíficas a nivel individual y grupal, Muñoz (2001) señala la socialización, la dulzura, la caridad, el cariño, la solidaridad, la cooperación y la ayuda mutua, entre otras. Rescato la cooperación y la mutua ayuda por la relación directa que tienen con las solidaridades tradicionales africanas. Son las dinámicas pacíficas de solidaridad, cooperación y ayuda mutua las que nos acercan al plano de la convivencia, entendida por Martínez Navarro (2004: 184) como "la situación en la que dos o más personas viven en mutua compañía, compartiendo un mismo espacio y tiempo [donde se exige] la realización práctica de ciertos compromisos en cuanto a respeto mutuo, cooperación voluntaria y a compartir responsabilidades".

Sobre las religiones y su carácter pacífico, señalan Molina y Cano (2001: 152) que "las religiones [...] tendrían por objeto -al menos en su origen- cubrir una serie de carencias del individuo y/o guiar unos intereses", acentuando en Molina et al. (2004: 120) que lo que permite a las autoras encontrar elementos relacionados con la paz en las religiones es "la consideración del hecho religioso [...] inherente a todas las sociedades, y que nunca es ajeno a los acontecimientos históricos, sociales, políticos o culturales". Son las paces interna y espiritual las que se pueden considerar como aportación de la religión a la paz.

\section{Espacios de paz y trayectorias}

"Lo que he conseguido no podría ni imaginarlo", E. Costa de Marfil

En esta exposición de resultados, las cualidades pacíficas presentes en las trayectorias que las y los participantes relataron no se pueden dividir como si de categorías diferenciadas se tratasen. Es por eso que las acciones solidarias, cooperativas y de ayuda mutua se dan en diferentes situaciones durante sus rutas de manera simultánea, puesto que son conceptos que van muy unidos a los valores de la comunidad.

Asimismo, es importante destacar la relevancia de estos espacios de paz en Marruecos, puesto que se trata del país que hace frontera con Melilla, país encargado de llevar a cabo un exhaustivo control fronterizo exigido y financiado por la Unión Europea y, por 
consiguiente, por el Gobierno español, en el que, según las entrevistadas, resulta más difícil vivir. La violencia es palpable en el territorio, teniendo en cuenta los testimonios de los migrantes e, incluso, el del periodista Blasco de Avellaneda (26 de junio 2015):

Europa dice [a Marruecos]

- «toma este dinero y haz lo que...». Lo que no van a hacer es matarles a tiros en la cabeza. Entonces, ¿qué hacen?:

- -¿Tú quieres entrar en España?, pues te parto las piernas y no entras-. Eso fue lo que se hizo al principio.

E. Guinea 4 (23 de junio 2015) aseguraba que "en Marruecos tienes miedo a dos cosas: a la policía y a los delincuentes", mientras que E. Costa de Marfil (24 de junio 2015) añadía que en Marruecos hay mucha gente racista: "te insultan, te llaman negra de mierda, te agreden. Si vas a la policía, lo primero que te preguntan es cómo se llama el agresor, pero ¿cómo lo vas a saber? Te dicen: «cuando lo sepas, vuelves»”.

Son muchas las personas africanas que se quedan en Marruecos durante largas temporadas, convirtiéndose el país alauí en un lugar de destino, de tránsito o de espera. Tanto mujeres como hombres pueden llegar a vivir allí durante años siendo detenidos y expulsados a otras ciudades, permaneciendo en los bosques, en casas de parientes o compatriotas, en las calles o en centros de internamiento. Es por esto que Marruecos supone un punto bastante conflictivo en la trayectoria migratoria de las personas subsaharianas y, por lo tanto, se verá reflejado en sus relatos con mucha frecuencia.

Los espacios de paz referidos en este trabajo abordan las relaciones interpersonales que ayudan a satisfacer las necesidades de las y los migrantes. Es Bredeloup (2009) quien señala la función de las redes sociales durante las rutas y el paso por los países de tránsito. Las personas entrevistadas comentaron cómo las redes que tienen en países de destino habían influido en sus decisiones de salir y de pensar en un lugar concreto al que llegar, como por ejemplo E. Senegal (1 de junio 2015), quien afirma su deseo de ir a Francia o Alemania, países donde tiene amigos senegaleses. Coincide con él E. Guinea 2 (12 de junio 2015), quien dice querer ir a Toulouse (Francia) porque allí tiene dos amigos. Además de la influencia que puedan tener estos contactos en las decisiones de estos dos jóvenes, son sus amigos quienes les 
informan sobre cómo se vive en las ciudades europeas. Así, E. Guinea 2 señala que llegar a Europa "es bueno para los clandestinos".

La ayuda prestada por las redes sociales de los migrantes africanos en las diferentes ciudades de tránsito es distinta según la situación de la persona que allí viva. Las personas asentadas en Malí, Argelia o Marruecos ofrecen apoyo a sus compatriotas o parientes en forma de alojamiento, comida, información y, si pueden, ayuda económica. E. Guinea 1 (3 de junio 2015), por ejemplo, durante su estancia en Rabat se quedó en casa de un "hermano mayor", al que llamó días antes de salir de Conakry para informarle de que iba para allá. Al referirse a su amigo como grand frère (hermano mayor), deja constancia de la idea tratada por Little (1970) sobre la consideración de los miembros de una comunidad africana como hermanas y hermanos.

En el caso de E. Nigeria (19 de junio 2015), su red migratoria estaba compuesta por varios de los amigos de su marido. De esta manera, la entrevistada y su marido pudieron alojarse en la casa de uno de sus amigos que vivía en Malí, sin necesidad de pagar ningún gasto, según ella misma afirma. Es también un amigo del marido que reside en Casablanca (Marruecos), el que les dice cómo E. Nigeria podía pasar la frontera con su bebé de seis meses. De hecho, la entrevistada consiguió pasar vestida con una chilaba, cubriendo sus manos y rostro, con su bebé tapado con un fular.

Por otro lado, cabe destacar el viaje de E. Costa de Marfil hasta Marruecos, puesto que es gracias a un amigo de su difunta tía que reside en Benín, cómo la informante se desplaza de un país a otro. Ella se queda en casa del amigo de su tía durante unos meses hasta que éste encuentra un transportista de confianza para que lleve a E. Costa de Marfil hasta Bamako (Mali), donde se queda en casa de otro amigo del primero. Es éste quien busca a alguien de confianza para que pueda acompañarles en el viaje, siempre escondida en la parte trasera de la camioneta, como ella misma contaba. La entrevistada agradece la solidaridad del amigo de su fallecida tía y habla de él como parte de su familia. De nuevo, los valores de hermandad están presentes en sus relatos, al mismo tiempo que los de cooperación y solidaridad, como es el caso de E. Guinea 5 (29 de junio 2015), a quien un amigo de su hermano que vivía en Marruecos le dijo: "hay un camino aquí. Si tú 
puedes enviar tu hermano aquí, yo le puedo ayudar para entrar en Europa. Él puede entrar y buscar su vida”.

E. Cruz Roja (6 de julio 2015) coincide con J. Palazón (1 de julio 2015) en afirmar que la mayor red social es creada en Marruecos, debido a las dificultades que encuentran. Es así cómo se puede rescatar la idea de Fall (2000) sobre el incremento de estrategias y redes como respuesta a las medidas restrictivas tomadas por los gobiernos. E. Cruz Roja, J. Palazón, C. Montero y Blasco de Avellaneda hablan de "mafias"; sin embargo, mientras que E. Cruz Roja y C. Montero (30 de junio 2015) hacen hincapié en la presencia de las mismas en todo el trayecto migratorio, Blasco de Avellaneda afirma que "lo que aquí se llama mafia, ellos lo llaman redes sociales de ayuda", sosteniendo que existen las dos en paralelo, pero que una mafia es "un grupo delincuencial transnacional que se dedica a sacar dinero a través de la extorsión y aprovecharse de los demás, ofreciéndoles una protección o simplemente extorsionando".

Nadie se puede creer que 500 tíos, 1.000 tíos, 2.000, o los que sean, estén tres meses, seis meses, nueve meses, un año, dos años, hasta siete años hemos encontrado a gente, tirados en un bosque a la intemperie, comiendo basura, mendigando, lleno de pulgas, lleno de heridas, con sarna, pasando un montón de enfermedades y de penurias, llenos de cortes y dejándose la vida saltando él de mutuo propio una valla, y entonces que el Gobierno diga que los negros que saltan la valla están movidos por las mafias.

Por su parte, J. Palazón (1 de julio 2015) añade que las entradas son "pura estrategia política y no hay nada más, nada más. El hecho de que estén en el Gurugú, incluso, es un hecho consentido y provocado por Marruecos".

Sobre los espacios de paz en los que están presentes la solidaridad y la cooperación cabe destacar el caso de E. Guinea 3 (15 de junio 2015) en la frontera entre Mauritania y Argelia. Según el informante, viajaban cuatro guineanos (él y tres chicos más) en un "vehículo-mafia" que les dejó a unos kilómetros de la frontera. Cuando los cuatro llegaron a pie a la frontera, les pararon los militares argelinos y el "capitán" les empezó a preguntar el motivo de su salida y si sus padres estaban al 
corriente de que se encaminaban hacia el norte de África. Afirma que el capitán les ofreció quedarse en su casa hasta encontrar un vehículo apropiado para llevarles hasta el norte de Argelia. Se quedaron en su casa durante un mes y medio. "No quería que les diéramos dinero. Todos eran amables con nosotros. [...] El Capitán era burkinés, y su mujer también. [...] Les llamábamos papá y mamá”.

E. Nigeria pone de manifiesto cómo los marroquíes la insultaban mientras pedía limosna en la calle, cuando vivía en Casablanca. Pero también señala que había personas solidarias con ella, puesto que le daban ropa para ella y para su hijo. Reitera constantemente que no fue nada fácil vivir en Marruecos y, mucho menos, pedir en la calle. En el caso de E. Guinea 5, el joven habla sobre el entrenador de fútbol que tuvo cuando jugaba en el F.U.S. Rabat, quien le dijo que no se preocupara por el dinero, que él le ayudaría hasta que su hermano pudiera mandarle algo desde Guinea. Además, E. Guinea 5 afirma haber entrado en Melilla en patera con el dinero que su hermano consiguió en Siguiri (Guinea Conakry) cogiendo oro. Es aquí donde quedan reflejadas las solidaridades tradicionales a las que se refiere Locoh (1993), donde la familia y las amistades juegan un relevante papel. E. Guinea 5 fue acusado de dirigir la patera en la que viajaban él y trece personas más y permaneció en el centro penitenciario de Melilla durante un año y dos meses. Cuando habla de Don Blas, el director del centro, afirma que se portó muy bien con él y que siempre estaba dispuesto a ayudarle. Asegura que pasaba las horas jugando al fútbol en la cárcel puesto que no tuvo ni un permiso durante el año y dos meses.

Sobre el fútbol, es Blasco de Avellaneda quien sostiene que en el Gurugú había incluso "campeonatos entre África central y África occidental, entre Camerún y Malí, entre todas las nacionalidades, campeonatos, mundiales... El fútbol a ellos les relajaba mucho y es una cosa que comparten prácticamente todos".

El caso de E. Guinea 4 es muy llamativo en cuanto a los espacios de paz imperfecta que se abordan, puesto que él y su hermano salieron juntos de Conakry, estuvieron viviendo poco más de un año en Siguiri (al norte de Guinea) y después se encaminaron hacia Malí. Cuenta el entrevistado que, al llegar a la zona maliense de Gao, un grupo de tuaregs armados se acercaron al autobús apuntando a todos los que en 
él iban a la cabeza y secuestraron a ocho personas, entre ellos E. Guinea 4 y su hermano. Horas más tarde, cuando los tuaregs les pidieron empezar a realizar algunos trabajos forzados, el hermano del informante se negó y, según cuenta E. Guinea 4, uno de los terroristas le golpeó con el fusil rompiéndole dos dientes, y se le llevaron. Nunca más le volvió a ver. Estuvo secuestrado durante tres semanas hasta que decidió intentar escaparse.

Había un tuareg que preparaba la comida. Tenía compasión por mí. Le expliqué mi caso y a veces me daba de comer durante la noche. Él era el único que hablaba francés. Le llegué a decir que si hubiera sabido que estaban ahí, no hubiera pasado por ese camino. Me dijo que si me portaba bien algún día me liberarían. Un día intenté salir, eran sobre las nueve. Escalé el muro y descendí al otro lado, por la parte de los baños.

Prosigue contando cómo corrió hasta que le faltaron las fuerzas y se quedó descansando, finalmente dormido. Cuando se despertó vio una camioneta y el conductor le preguntó que si iba a Argelia, y él le dijo que sí. De esta manera, E. Guinea 4 se subió en la parte trasera del vehículo y consiguió alejarse del lugar donde su hermano había desaparecido y donde a él le apuntaban constantemente con un fusil. "Había comida de ovejas, había sacos. Allí me recosté, en la parte de atrás de la camioneta". Así llegó a Argelia.

Siguiendo con los espacios en los que la cooperación y la solidaridad están presentes, rescato las palabras de E. Senegal cuando habla de los "hermanos" que ya han conseguido pasar la frontera de Marruecos con Argelia y les llaman para avisarles de cómo está la situación en el momento que tengan pensado cruzar. Afirma que durante el trayecto en camioneta de Níger a Argelia, que duró unos tres días, la relación entre los viajeros era buena, afirmando que "nosotros somos africanos, nos ayudamos. Además, todos llegamos allí para lo mismo: cruzar a Argelia". El Padre Esteban (Nador, 28 de junio 2015) señala que "aunque haya tensiones fruto de una vida muy dura, [...] el objetivo común está por encima de todo". En el caso de E. Guinea 3 es importante señalar la referencia que hace sobre los conductores en África, puesto que cuando llegó a Burkina Faso se alojó junto a dos "amigos de viaje" en casa de un conductor que había conocido en una estación de autobuses, de la cual no recuerda ni el lugar. Prosigue 
"nosotros los conductores tenemos amor entre nosotros. Puedo salir desde Guinea a Nigeria sin pagar nada".

Es E. Costa de Marfil quien habla de cooperación con la familia que la acogió en Bamako porque ella cuidaba a las niñas pequeñas mientras estaba allí. Es relevante señalar cómo cuando se la pregunta por el nombre de los conductores afirma que ellos "no dicen sus nombres, están ayudando a los clandestinos". Es E. Guinea 2 quien se refiere también a él mismo como "clandestino", puesto que "no tiene pasaporte ni visado".

Por otro lado, C. Montero y E. Cruz Roja coinciden en algo que también está presente en los valores africanos: los hijos y las hijas se crían en comunidad. Es por esto que C. Montero habla de las personas subsaharianas que han llegado hasta el CETI con un niño o una niña que no era su hijo o su hija, puesto que "el pensamiento que tiene el africano es muy distinto: si por el camino su padre o su madre mueren o desaparecen, ellos se hacen cargo de esas niñas... Se agrupan y se ayudan entre ellos".

J. Palazón y E. Cruz Roja resaltan la responsabilidad con la que vienen las personas desde los distintos países de África subsaharianas para poder encontrar un empleo y mantener a sus familias, tal y como cuenta E. Guinea 5: "yo podría hacer lo que quiero, pero la familia está muy grande y no puedo ayudar a toda la familia con ese dinero, ¿sabes? Necesito trabajar más".

El Padre Esteban apunta que la inexistente ayuda por parte de los países por los que pasan favorece esta ya ayuda mutua en sus sociedades de origen. E. Guinea 2, por ejemplo, relata cómo fabricaron una escalera en la camioneta donde viajaban él y siete personas más hacia la frontera con Marruecos. Cuenta además que en esta frontera hay un foso muy profundo antes de una valla, donde muchas personas han perdido su vida, puesto que además de la valla y el foso, hay militares. Asimismo, añade E. Senegal que "cuando los militares argelinos y marroquíes te ven en la frontera, te hacen daño, te pegan, te rompen las piernas", es por esto que deben ayudarse los unos a los otros, vigilando para cruzar y con cuerdas para escalar y no perecer en el foso. Responden estas situaciones y la creación de estos espacios de paz a las necesidades de seguridad y supervivencia. 
El Padre Esteban hila los conceptos de supervivencia y solidaridad con la existencia de una sólida auto-organización en los bosques de la provincia de Nador, como el Gurugú, Bolingo o Selouane. Autoorganización también presente en las diferentes ciudades de tránsito y, según los ocho informantes, sobre todo en Argelia y Marruecos, siendo este último de gran importancia. Es E. Guinea 2 quien habla de un "jefe argelino" que espera a los "clandestinos" en la frontera de Argelia, "si haces boza [victoria] allí te esperan". Señala el entrevistado que de allí le llevaron a trabajar en unos cultivos, ganando algo de dinero, con alojamiento y comida. Además, cuenta que cuando llegó a Rabat (Marruecos) había un "black" que acogía a los guineanos, porque, según comenta, en las grandes ciudades también se agrupan por comunidades, algo que me dijeron en repetidas ocasiones durante la observación participante.

Hay un sitio que se llama Chad [en Rabat], es un barrio donde están todos los black de Rabat. Ningún problema [entre nosotros]. Hablamos en nuestro idioma, nos olvidamos de los problemas. Lo único que decíamos es que Dios nos ayude. (E. Guinea 2)

E. Senegal habla de la figura del koseaur. Se trata, según explica, de la persona que les recoge en diferentes países y les lleva a su casa hasta que encuentra un vehículo para poder seguir el viaje. Cuando es preguntado por la casa en la que vivía, E. Senegal asegura que había muchísima gente y que hay un koseaur para cada comunidad, que están separadas por nacionalidades. Añade la entrevistada E. Costa de Marfil: "una vez que llegas a Rabat, preguntas por la comunidad marfileña". Por otro lado, eran los distintos bosques de Nador espacios de conflictos y paces. El Padre Esteban afirma que a los asentamientos de los bosques se los denomina "campamentos por llamarlos de alguna forma, porque aquellos lo que son... cuatro plásticos y... poco más”. E. Guinea 2, E. Guinea 4 y E. Senegal estuvieron en el monte Gurugú durante varios meses, mientras que E. Guinea 3 estuvo yendo y viniendo del bosque Bolingo (en Mariouari, barrio fronterizo con Melilla) durante seis meses y E. Guinea 5 estuvo en el bosque de Selouane. E. Guinea 1 permaneció en el Gurugú sólo una noche, y las mujeres, E. Nigeria y E. Costa de Marfil desconocen los bosques, no 
vivieron en ellos. La organización de los campamentos es muy similar entre unos y otros.

Todos coinciden en afirmar que hay un "jefe", "líder" o "presidente" de cada comunidad, -compuesta por las personas de un mismo país-, uniéndose las comunidades más pequeñas en algunos casos con otras más grandes. Se refieren a una ley interna llamada la "Loi du Ghetto" (ley del gueto), a través de la cual se marcan unas pautas de actuación y funciones dentro de la comunidad. El "líder" es el encargado de otorgar a cada quien su papel, de reunirse con los demás líderes en caso de conflicto y de organizar los saltos a las vallas. Señala E. Senegal: "el líder pone la ley. [...] Cada día tenemos que dar tres dirhams para comprar, cocinar y comer. Para vivir juntos sin problemas". E. Cruz Roja añade que "es el que pone orden, el que dice quién debe ir a por agua, quién hace la comida o quién puede curar una herida".

Respecto a la resolución de los conflictos en los asentamientos, E. Guinea 4 afirma que son los líderes quienes se encargan de resolverlos. Todas las personas con las que hablé repetían constantemente las dificultades de la vida en los bosques. E. Guinea 5 hace referencia a la función de los vigilantes como defensa de los posibles "chivatos" del Gurugú, que están en contacto con la policía marroquí y, por supuesto, para avisar a tiempo en caso de redada en el campamento, ya que el entrevistado afirma que "hay gente que perdió sus ojos, sus piernas, sus brazos" por las agresiones policiales. E. Guinea 3 también habla de la importancia del vigilante de la comunidad guineana en Bolingo, puesto que la amenaza de las fuerzas auxiliares marroquíes es una constante.

"Es cierto que vas a los campamentos y allí hay un jefe, hay intermediarios, gente que manda sobre gente, pero eso no son mafias... Es la única forma de sobrevivir", defiende el periodista Blasco de Avellaneda. Continúa señalando que es la forma de organizarse y de "no matarse a palos", puesto que, según prosiguen, en el monte Gurugú ha llegado a haber 2.500 personas de 30 países diferentes, con lo que "si no hay alguien que sea jefe, que hablen entre ellos, ¿cómo se organizan?”. Asimismo, el Padre Esteban apunta esta forma de organización como "seguridad" y "protección" del grupo frente a la fuerte represión policial y social contra ellos en Nador: "yo he visto un furgón, aparentemente civil, y de repente se abre y ipum!, ven un negro y lo meten dentro. La gente tiene miedo de atenderles, de meterles [a 
trabajar] si no tienen papeles en algún sitio". Coinciden el Padre Esteban y Blasco de Avellaneda en que la urgencia humanitaria es total y constante en los bosques.

Los saltos a las vallas también son organizados. La mayoría de los entrevistados afirman haberlo intentado en varias ocasiones, y no en grandes grupos, si no cinco o diez, o incluso, solos. E. Senegal apunta que él lo intentó unas diez veces, siendo expulsado por la policía marroquí a Rabat y Fez en varias ocasiones. Finalmente, consiguió entrar con 40 personas en febrero de 2015, coincidiendo con la quema del Gurugú. El único caso de intento de salto numeroso lo relata E. Guinea 2:

Nosotros intentamos pasar dos veces la valla, pero ni siquiera llegamos a acercarnos a ella. Tú puedes ver a 200 personas... Hacemos una línea. El jefe de la comunidad es el guía. Cada diez personas hay un guarda, [...] Eso lo hacemos por la noche. Sobre las cinco de la mañana, cuando está amaneciendo, saltamos la valla. Él es quien determina el polo. Es en el momento que ves el helicóptero y hay que tumbarse en el suelo.

E. Guinea 2 señala que él finalmente consiguió pasar solo. En cuanto a la actitud de las fuerzas auxiliares marroquíes, afirma que "si los aly te cogen, te van a pegar hasta que te olvides de Europa", puesto que les golpean causando incluso roturas o lesiones muy graves, como afirma la gran mayoría. Por otra parte, J. Palazón señala que cuando hay un salto numeroso se trata de un salto "consentido, querido y provocado por el gobierno hispano-marroquí para provocar la correspondiente alarma", añadiendo la imposibilidad de que 500 personas no sean vistas antes de llegar a las vallas fronterizas.

Por otro lado, las creencias religiosas forman parte de las vidas de las personas africanas $\mathrm{y}$, por consiguiente, también están presentes en sus trayectorias migratorias. Es importante tener en cuenta el papel de la religión como medio para satisfacer algunas necesidades, dar respuesta a distintos problemas o guiar intereses (Molina y Cano, 2001). Así, los musulmanes se refieren a Allah con bastante frecuencia, utilizando expresiones como Alhamdulilah -gracias a Dios-e Incha Alllah -si Dios quiere-, en referencia a su entrada en Melilla. Las personas cristianas repetían "Dios es la fuerza", agradeciéndole constantemente el seguir 
vivas. E. Guinea 1 sostiene que "es Dios quien me ha guiado hasta aquí. Yo no conocía nada y llegué. Cuando estaba en Conakry, mi objetivo era Marruecos. Cuando estaba es Marruecos, vine aquí. Yo no sabía que iba a venir aquí’. El joven E. Guinea 3 asegura que cuando entró en el CETI de Melilla sólo rezaba para que Dios también ayudara a sus amigos para poder saltar las vallas y entrar en la ciudad. E. Costa de Marfil, cristiana, y E. Guinea 4, musulmán, coinciden en que Dios les dio la oportunidad de pasar a Melilla el día que lo consiguieron, sostienen que es Dios quien decide si entran o no.

Es el Padre Esteban quien llevó a cabo en el monte Gurugú varias "oraciones interreligiosas" en las que cada cual rezaba a su manera, pero compartiendo un mismo espacio y tiempo, según cuenta. Llevaba el Corán y la Biblia. En los bosques se habilitan zonas de rezo.

La lengua es un elemento primordial en la creación de relaciones pacíficas o violentas (Muñoz y Jiménez, 2004), por lo que la resaltamos en la presente exposición por funcionar como herramienta de cohesión y convivencia. De hecho, varias personas afirmaron que cualquier africano que haya estado en el Gurugú conoce el significado de ciertas palabras. E. Guinea 2 dice que "cuando llegas a Marruecos aprendes muchas palabras en idiomas diferentes. Bumbulá, por ejemplo, es redada policial; boza es entrar, hacer victoria". Por otro lado, el nombre del bosque Bolingo significa "amor" en una de las lenguas congoleñas.

En cuanto a la palabra boza, la utilizan todas las personas que tuve oportunidad de conocer, incluso los medios de comunicación. En el CETI se habla de nuevo o nueva boza cuando llega un africano, no siendo relevante la forma de entrada a Melilla. Es E. Guinea 1 quien se refiere como polo free a la parte de la valla donde no hay concertinas, como señala E. Senegal. Mientras, E. Guinea 3 habla sobre los aly, que es como llaman a las fuerzas auxiliares marroquíes, y E. Guinea 2 cuenta lo que es para ellos hacer fuck off, -ser chivato de la policía marroquí- y habla del tranquilo, que es la parte del Gurugú donde se esconden cuando hay redadas policiales. Añade el periodista Blasco de Avellaneda que es el lugar donde se esconden normalmente las mujeres con las niñas y niños. Por otro lado, apuntan el dernier tranquilo (el último tranquilo) como el momento en el que el grupo que va a saltar las vallas se para a unos metros de las mismas a rezar. El objetivo es alcanzar territorio europeo sin perder la vida. 


\section{Conclusiones}

Recuerdo aquellos días de septiembre y octubre de 2014 cuando en los telediarios y en los periódicos se nos informaba de que cientos de africanos estaban saltando las vallas de Melilla. Fueron algunos intentos de saltos numerosos los que ocasionaron que licación tuvieran la justificación perfecta para hablar de invasión. Mientras, la Unión Europea aumentaba los controles fronterizos otorgando una responsabilidad mayor de vigilancia a Marruecos. El país alauí endureció sus políticas de control y esto ha hecho que la estancia de las personas subsaharianas en Marruecos sea cada vez más complicada, sumada a que las dificultades por conseguir llegar a las vallas son mayores.

Aunque la presente investigación trata de las trayectorias migratorias desde los países de origen, es un hecho que el tránsito por Marruecos y el mediático salto a las vallas son puntos muy destacables. Cierto es que las vallas de Melilla se convierten, según las personas subsaharianas con las que hablé, en el último obstáculo para llegar a la ciudad autónoma, "el satélite de África", como lo definió E. Senegal. Entender Marruecos como país de tránsito, destino o espera y, además, como tercera frontera de la Unión Europea, significa poder acercarse a una realidad cargada de conflictos y violencia, puesto que las detenciones, las expulsiones, las redadas, las agresiones y las violaciones son parte de la realidad de las personas subsaharianas que están en Marruecos y, sobre todo, de quienes se acercan a las ciudades fronterizas. Es por esto que algunos afirman que "la frontera no es para los black", añadiendo que es la policía marroquí quien se lo dice en diferentes ocasiones.

Las personas que salen de Ghana, Costa de Marfil, Camerún o desde cualquier otro país africano, tienen que pasar por diferentes territorios donde la inestabilidad política y la violencia están presentes, como es el caso de la zona del Sahel. Así, hemos comprobado que algunos de los y las entrevistadas se toparon con grupos armados en los desiertos de Malí o Argelia. Así, como ellas y ellos afirman: no es fácil, “c'est pas facile", "it's not easy". Un camino por el que se encuentran ladrones, terroristas, militares, policías y grupos de extorsión, además de múltiples dificultades a las que deben ir haciendo frente, tal y como se ha ido señalando. 
Teniendo en cuenta las solidaridades tradicionales africanas (Locoh, 1993) que engloban la vida en comunidad y el sentido de la colectividad como forma de estructuración social, nos encontramos con estos valores en las trayectorias migratorias, donde priman los intereses comunes, como la mayoría de las personas entrevistadas afirmaron con una gran sonrisa: "claro que nos ayudamos, nosotros somos africanos". La común respuesta de sociedades occidentales sumamente individualistas atravesadas por el racismo estructural e institucional y, por supuesto, de muchos medios de comunicación a esta forma de organización social en comunidad es tacharla de primitiva, deshumanizando a sus protagonistas, quienes desde la paz imperfecta ya descrita son verdaderas promotoras de paz. Así, tal y como se ha señalado, los espacios de paz están presentes en las trayectorias migratorias, y esto me lleva a la necesidad de hacerlos visibles para potenciarlos entre los discursos mediatizados más generalistas que llevan al racismo, la xenofobia y el odio, puesto que "sin [la paz] no habríamos sobrevivido o evolucionado, y por tanto, debe ser protegida, cuidada y mimada" (Muñoz, 2004: 885).

Al mismo tiempo, me parece imprescindible señalar la existencia de medios de comunicación, proyectos periodísticos y comunitarios que abogan por una información cuidadosa y comprometida con los Derechos Humanos, al tiempo que visibilizan las variopintas potencialidades africanas, que son infinitas. También hacer referencia a las distintas organizaciones, asociaciones y colectivos que trabajan denunciando las violencias racistas institucionales cometidas en las fronteras, en los caminos y en los países de llegada; a quienes trabajan por la protección de las personas migrantes en países de tránsito, en el mar, en las vallas y ya en territorio europeo; a todas las personas que creen en la dignidad humana y que trabajan cada día por deconstruir la realidad estereotipada y sesgada de las personas que se mueven, de sus países de origen y de sus vidas. Esta es la verdadera esperanza y donde, por supuesto, la comunicación juega un papel muy importante en cuanto a humanizar a todas las personas que habitamos el mundo.

El presente trabajo de campo se llevó a cabo en 2015, sin embargo, la realidad de las personas migrantes sigue siendo la misma: los medios continúan emitiendo informaciones que incitan al odio y las violentas políticas de la Unión Europea siguen condenando las vidas de las 
personas que pretenden llegar a un supuesto continente civilizado. Participan aquí quienes lo han logrado, pero no podemos dejar a un lado los miles de personas que pierden sus vidas en los desiertos, los bosques, los centros de internamiento, las vallas y el mar.

Para concluir, señalar el gran reto comunicativo por deconstruir estereotipos y construir nuevas formas de entender las realidades, y por promover, cuidar y mimar las paces. También el reto social por desaprender los constructos patriarcales, capitalistas y racistas, y por aprender formas alternativas más coherentes con los valores colectivos y la justicia social. África tiene mucho que enseñarnos, con lo que para finalizar, rescato las palabras del periodista Blasco de Avellaneda al afirmar que "un movimiento nunca puede ser un problema, es parte de la solución".

\section{Bibliografía}

Aldalur, M. (2010). Clandestinos. ¿Qué hay detrás de la inmigración ilegal? Barcelona: Editoriales B.

Ascanio, C. (2007). Comparando migraciones, discursos y prácticas: el ejemplo de las Islas Canarias. Revista de Análisis Sur/Norte para una Cooperación Solidaria, (43), 55-72.

Bredeloup, S. (2009). La migration africaine: de nouvelles routes, de nouvelles figures. Revue Quart Monde, 4(212).

Crespo, R. (2009). Bamtaare, una concepción africana de codesarrollo. En F. Checa, A. Arjona y J.C. Checa (Eds.), Globalización y movimientos transnacionales. Las migraciones y sus fronteras (pp. 81-94). Almería: Universidad de Almería.

Fall, B. (2000). Migraciones internacionales y Derechos Humanos en el África negra. Revista Mugak, (13).

Little, K. (1970). La migración urbana en África occidental. Barcelona: Editorial Labor.

Locoh, T. (1993). Formes modernes et traditionnelles de la solidarité. Solidarités et survie des populations africaines: quel rôle pour la famille, l'État et les autres acteurs sociaux. En J.C. Chasteland, J. Véron, y M. Barbiéri (Dirs.), Politiques de développement et croissance démographique rapide en Afrique, (pp. 215-221). París: PUF. 
Martínez Navarro, E. (2004). Convivencia. En López Martínez (Dir.), Enciclopedia de Paz y Conflictos, 1. Granada: Universidad de Granada.

Molina, B. y Cano, M. J. (2001). La paz desde la diversidad cultural y religiosa. En F. Muñoz (Ed.), La Paz imperfecta, (pp.143-179). Granada: Eirene.

Molina, B., Cano, M. J. y Rojas, G. (2004). Culturas, religiones y paz. En B. Molina y F. Muñoz (Eds.), Manual de Paz y Conflictos, (pp. 97-117). Granada: EUG.

Muñoz, F. A. (2001). La Paz imperfecta. Granada: Eirene.

Muñoz, F. A. (2004). Paz imperfecta. En M. López Martínez (Dir.), Enciclopedia de Paz y Conflictos, 2, (pp. 898-900). Granada: Universidad de Granada.

Muñoz y Jiménez Bautista (2004). Violencia. En López Martínez (Dir.), Enciclopedia de Paz y Conflictos, 2. Granada: Universidad de Granada.

Ruiz Jiménez, J. A. (2004). Conflicto. En López Martínez (Dir.), Enciclopedia de Paz y Conflictos, 1, (pp.149-152). Granada: Universidad de Granada.

Ruiz Olabuénaga, J. I. (2012). Metodología de la investigación cualitativa ( $5^{\mathrm{a}}$ ed.). Bilbao: Universidad de Deusto.

Sandoval, E. A. (2009). Ciudadanía universal, derechos políticos y paz en la migración. En V. Martínez Guzmán y E. A. Sandoval (Eds.), Migraciones, conflictos y cultura de paz (pp. 19-44). México: Cátedra UNESCO de Filosofía para la Paz. 30.000 inmigrantes aguardan en Marruecos para saltar a Ceuta y Melilla (2014, 16 de febrero). El País. 


\title{
E1 "Italiano L2" en la escuela italiana: perspectivas de los profesionales de la escuela y del alumnado extranjero en las escuelas secundaria de segundo grado en Palermo ${ }^{43}$.
}

\author{
Vincenza Indelicato \\ Universidad de Granada, España
}

\section{Resumen}

Los flujos migratorios de estas últimas décadas han afectado Europa en general, a Italia en particular y han resultado especialmente relevantes en Sicilia. Examinando las estadísticas nacionales y regionales estas muestran que, asociado a la permanencia de un número significativo de inmigrantes, se ha generado un notable incremento de estudiantes extranjeros en las escuelas.

La relevancia de este fenómeno en la escuela italiana tiene que con problemas no sólo de integración, pero sobre todo con problemas de comprensión y comunicación en lengua italiana por parte del alumnado extranjero que estudia en Italia.

\footnotetext{
${ }^{43}$ El presente texto está ligado a mi tesis de doctorado, en fase de elaboración, sobre el uso de las lenguas por parte de los estudiantes extranjeros en la escuela italiana. Dicha tesis se está realizando en el programa de doctorado en Estudios Migratorios de la Universidad de Granada, bajo la dirección del Dr. J. F. García Castaño que agradezco por sus comentarios a una primera versión de este texto. También quiero agradecer al Ministerio Italiano de Educación la concesión de un permiso por estudios para el desarrollo de mi tesis doctoral. Contacto: vindelicato@correo.ugr.es
} 
En 2015 con la Ley 107, conocida como "Buena Escuela", entre las diferentes novedades, se oficializa por primera vez el nacimiento del "Italiano L2" considerada como "lengua extranjera para estudiantes extranjeros/ extranjeras en las escuelas italianas".

Para conocer el proceso de implantación y uso del Italiano L2, hemos investigado en las escuelas superiores de segundo grado situadas en las áreas de Palermo (Sicilia) con mayor población inmigrante. En nuestro trabajo de campo hemos producido informaciones relativas a la enseñanza/ aprendizaje del "Italiano L2" y en el presente artículo destacaremos el punto de vista de los profesionales de la escuela y del alumnado extranjero que viven a diario la situación organizativa y didáctica del cumplimiento de la susodicha Ley. Durante las entrevistas se han planteado los asuntos educativos y didácticos con respecto a una organización práctica de la de enseñanza de esta asignatura y la necesidad de reflexionar sobre las motivaciones de las dificultades lingüísticas de aprendizaje del alumnado extranjero.

Palabras clave: Escuela Italiana, Italiano L2, reforma escolar, estudiantes extranjeros, profesionales escolares.

\section{Introducción}

— ESTOS últimos años los flujos migratorios han ido en Si nos referimos en particular a Italia, este ciclo de cambio social es relativamente reciente: ha alcanzado dimensiones significativas en torno a los primeros años de los años setenta para después caracterizar una nueva Italia alrededor de los primeros años del siglo XXI.

La estabilización de un número cada vez más significativo de inmigrantes se relaciona con un notable incremento de la presencia de estudiantes extranjeros/extranjeras en las escuelas italianas.

De hecho, nuestra investigación se dirige precisamente al alumnado extranjero en la escuela secundaria de segundo grado en Palermo, con el objetivo de investigar el uso que hace del italiano como segunda lengua. 
Queremos detenernos, ahora, brevemente en algunos de los puntos principales de nuestra investigación antes de llegar al asunto de este artículo.

¿Por qué hemos elegido en particular la escuela secundaria de segundo grado en Palermo?

Si en Italia, en estos últimos años, los flujos migratorios han ido en continuo crecimiento, en Sicilia y en particular en Palermo, este fenómeno ha alcanzado dimensiones significativas caracterizando el nuevo escenario sociocultural actual.

En efecto, refiriéndonos en particular a la escuela secundaria de segundo grado en Palermo, los últimos datos de 2018 de USR ${ }^{44}$-Sicilia, muestran que 1.543 alumnos de origen no italiano, de un total de 41.269, asisten a estos centros escolares.

(USR- Sicilia, 2018).

Francesco Macrì, uno de los miembros del Consejo Superior ${ }^{45}$ del $\mathrm{MIUR}^{46}$, refiriéndose a este alumnado, pone de relieve que:

en el 2016/2017 los estudiantes con ciudadanía no italiana presentes en la escuela secundaria de II grado son 192.000, con un aumento del 2,21\% (+4.138 estudiantes respeto al año anterior. [...] La escuela secundaria de segundo grado se puede considerar el sector relativamente más dinámico en lo que concierne la introducción de estudiantes de origen no italiano ${ }^{47}$ (Macrì, 2018:1)

\footnotetext{
${ }^{44}$ El USR es la Oficina Escolar Regional de Sicilia.

${ }^{45}$ El Decreto Ministerial 980 del 31 diciembre de 2015 designa a los miembros del CSPI, el Consejo Superior de la Educación Nacional, que es el órgano de garantía de la unidad de la educación nacional. Tiene tareas de soporte técnicocientífico con respecto a la educación universitaria, los órdenes escolares, los programas escolares, la organización general de la instrucción escolar y el estado jurídico del personal.

${ }^{46}$ MIUR es el Ministerio de Educación, Universidades e Investigación

47 Todas las traducciones al español a lo largo del texto están realizadas por la autora.
} 
La importancia del trinomio "inmigración-lengua-escuela" se vuelve básico en nuestro trabajo de campo realizado dentro de la realidad escolar cotidiana del alumnado extranjero. En efecto la escuela es el lugar y el contexto por excelencia en los que se realiza comunicación lingüística entre alumnos/ alumnas y entre ellos/ellas los/ los profesores/profesoras. Para permitir de la mejor manera esta comunicación se realiza el uso del "Italiano L2", es decir la "lengua italiana para el alumnado extranjero", establecida por la Ley 107/ 2015. En esta Ley ${ }^{48}$ el artículo 1, apartado 7, letra r) establece:

[...] Alfabetización y perfeccionamiento del italiano como segunda lengua a través de cursos y talleres para estudiantes de ciudadanía o lengua no italiana, organizados también en colaboración con las entidades locales y el tercer sector, con la contribución de las comunidades de origen, de las familias y de los mediadores culturales y un aumento del número de docentes en los institutos más multiétnicos (Gazzetta Ufficiale n.162, 2015: 1)

Como afirma Luisa Martín Rojo, los estudios sociolingüísticos, desde sus orígenes, han expresado su preocupación por cómo se dirigen, a lo largo del proceso educativo, los recursos lingüísticos, porque según la manera en que esta tarea se realice incidirá en la vida social de los estudiantes:

La escolarización entraña, ciertamente, la instrucción en las lenguas y en las formas estándar, que están socialmente legitimadas. El acceso a estos recursos lingüísticos es requisito para garantizar el acceso a otros recursos: económicos, sociales, laborales y simbólicos, es decir, para garantizar la movilidad social de los alumnos (Martín Rojo, 2003:19)

El aprendizaje/enseñanza del Italiano L2 empieza en el contexto de la escuela, pero sin embargo va más allá de esta. En la escuela, el aprendizaje y uso de la lengua del país de acogida debería prever que todo eso incidirá sobre el proyecto de vida "social" futura de estos

${ }^{48}$ La Ley 107/ 2015, que es actualmente en vigor, ha reformado todo el sistema nacional italiano de educación y formación, y que es más conocida como "Buena Escuela". 
estudiantes ya que su "comunicación lingüística" se empleará también en lugares y contextos fuera de la institución escolar.

En septiembre de 2015, para planear el aprendizaje/enseñanza del Italiano L2, el "Osservatorio Nazionale ${ }^{49}$ del MIUR" elaboraba el "Decalogo di accoglienza"50 titulado "Diversi da chi?"51 (Osservatorio Nazionale, 2015).

El punto 6 de este documento destaca la necesidad de "incentivar el aprendizaje del Italiano L2", como lengua escolar y subraya la exigencia de establecer, en los centros escolares, los "laboratorios de idiomas permanentes" realizados por docentes especializados en la enseñanza del Italiano L2. De hecho, en febrero de 2016, el MIUR comunica el nacimiento de la nueva clase de concurso denominada "A-23 lengua italiana para alumnos de lengua extranjera" que incluye a todo el profesorado adecuadamente formados para la enseñanza del Italiano L2 (Gazzetta Ufficiale n.43, 2016).

Todavía, hasta el día de hoy, falta un reconocimiento oficial de la figura del "profesor de italiano para extranjeros" y también del "Italiano L2" como asignatura escolar. De las entrevistas efectuadas en el trabajo de campo hemos abordado las dificultades de enseñanza/aprendizaje del italiano como L2 además hemos producido conocimiento de intentos metodológicos que se "inventaron" los profesores de algunos centros escolares para promover el conocimiento y uso de la lengua italiana a los estudiantes extranjeros para cubrir las faltas de la Ley 107/2015.

\section{Metodología investigadora y trabajo de campo}

Desde el punto de vista metodológico, hemos elegido el método de investigación cualitativa.

Nos pusimos en contacto, por correo electrónico, con los/los directores/directoras de ocho centros de secundaria de segundo grado de Palermo que contaban con una presencia significativa de estudiantes de origen no Italiano. Pero sólo tres directores/as aceptaron encontrarse con nosotros para acordar las fechas en las que llevar a cabo las entrevistas a los estudiantes extranjeros/ extranjeras de sus

\footnotetext{
${ }^{49}$ El Observatorio Nacional del MIUR trata la integración de los/ los alumnos/alumnas extranjeras /extranjeras y la intercultura.

50 "Decálogo de acogida"

51 "¿Diferentes de quién?"
} 
centros. De modo paralelo, identificamos, en estos centros, un grupo de profesores/as expertos/as en el ámbito lingüístico escolar y nos encontramos con 29 jóvenes (16 chicos y 13 chicas) de entre 14 y 19 años de nacionalidad extranjera que asistían a estos centros escolares.

Desde estas dos perspectivas hemos producido conocimiento para comprender las problemáticas que plantea la enseñanza/aprendizaje del italiano como L2.

Tanto con el alumnado como con el profesorado y los directores realizamos entrevistas estructuradas y semiestructuradas, "cara a cara" con una interacción directa, que se grabaron para ser posteriormente transcritas. Algunas veces realizamos nuevas entrevistas a los mismos sujetos de nacionalidad extranjera, para evitar recoger respuestas involuntariamente falsas. Durante el trabajo de campo elaboramos notas detalladas, que incluían descripciones de personas, conversaciones, acciones, conductas, sentimientos y también los acontecimientos y las hipótesis que surgían en el proceso de investigación.

En las entrevistas estructuradas con respuestas abiertas planteamos al alumnado siempre las mismas preguntas, formuladas de la misma manera y en la misma secuencia, sobre todo para obtener información acerca de los datos sociodemográficos (edad, condiciones sociales / económicas de la familia, cultura y lengua de origen). En las entrevistas semiestructuradas, realizadas siguiendo un protocolo sobre el "uso" de la lengua, elaboramos las preguntas en función de un esquema flexible, según las situaciones del alumnado extranjero entrevistado, permitiéndonos repetir también algunas preguntas para profundizar algunas informaciones y dando posibilidad de expresarse libremente, por ejemplo cuando empezaban a hablar del uso del Italiano en contextos y lugares externos a la escuela o incluso del uso de su lengua de origen.

Además, en algunos casos específicos, hicimos entrevistas de grupo (focus group) y usamos "preguntas-sonda". Entrevistamos a siete chicos de origen no italiano, que asisten a distintas aulas en la misma escuela de Palermo, que viven en casas de acogida, que tienen la misma experiencia de "proyecto migratorio" hacia Sicilia y que llegaron en pateras. Todos ellos mostraban reticencias y resistencias a la entrevista 
individual y pidieron expresamente ser entrevistados juntos. con las técnicas de "focus group" y de "preguntas-sonda", estimulamos el diálogo a partir de una conversación abierta, haciendo que las argumentaciones girasen en torno al uso del Italiano como L2 con el objetivo de conocer sus puntos de vista y así obtener los datos necesarios para nuestra investigación. Las intervenciones, que no eran auténticas preguntas, funcionaban como preguntas-estímulo que animaban a los estudiantes entrevistados a expresarse tranquilamente bajando las defensas, permitiendo seguir su propio hilo discursivo sin interrupciones y de modo que se expresaran libremente antes de plantear preguntas acerca del uso de la lengua (Corbetta, 2016).

Por otro lado, a partir de la observación participante en las aulas o durante el descanso, registramos la frecuencia de las interacciones lingüísticas, el uso de la lengua italiana entre los estudiantes extranjeros y los autóctonos y entre los estudiantes de diferente origen y obtuvimos datos más allá de los que se pueden reportar de manera verbal. Por ejemplo, muchos chicos y chicas que durante la entrevista afirmaban usar siempre el italiano con todo el mundo en el centro escolar, observados en el recreo, hablaban en su lengua de origen con los compañeros de la misma nacionalidad y dialogaban también en dialecto siciliano con los chicas y chicos italianos. Como afirma Anguera Argilaga:

la observación participante facilita y proporciona la posibilidad de implicarse en las actividades que se están desarrollando allí donde se están desarrollando, para fijarse en quién hace qué, cuándo y cómo, tomando nota de la relación entre la estructura espaciotemporal de las situaciones, los sujetos y los objetos presentes delante de nosotros. también permite que la información sea recogida en situaciones naturales, es decir, en el contexto en el que ésta se produce, dentro de "sus referencias espaciotemporales (Anguera Argilaga y Aguirre Baztán, 1995:75). 


\section{Enseñanza/aprendizaje del Italiano L2: puntos de vista del profesorado, de los/las directores/directoras y del alumnado extranjero}

Con respecto a la Ley 107/2015, a sus propuestas de innovación lingüística/ escolar y de planificación didáctica del Italiano L2 como asignatura escolar, hemos recogido datos mediante entrevistas a los protagonistas de los centros escolares: profesorado, directores/ directoras y alumnado extranjero.

\section{Punto de vista de un grupo de directoras escolares y de profesores}

Los extractos de algunas de las entrevistas realizadas a los profesionales de los centros escolares contactados evidencian la situación real de la introducción del Italiano L2 en las escuelas. Han surgido las dificultades de "enseñar" el Italiano L2, debido a las limitaciones de la Ley 105/2015 y en los desarrollos relacionados con la misma, enviados hasta el día de hoy por el MIUR a todas las escuelas. Con respecto a la organización didáctica escolar, todas las directoras y el profesorado entrevistado subrayan que la normativa no establece objetivos didácticos específicos, ni metodologías de enseñanza del Italiano L2 y tampoco indica una reorganización horaria; pero que, sin embargo, han surgido estrategias educativas y didácticas "creadas" por el profesorado para facilitar la enseñanza de esta lengua extranjera al alumnado no italiano.

Daniele $^{52}$, director de un centro profesional, explica:

la ley ha permitido considerar la necesidad de enseñanza del Italiano L2 a nuestros estudiantes en crecimiento. ¡Es óptimo! consideremos que sólo en este instituto asisten 61 alumnos extranjeros de unos 470 miembros. Pero para realizar esta enseñanza tenemos grandes dificultades: en primer lugar, crear cursos de italiano para extranjeros en el aula porque no tenemos normativa que regule la realización de éstos y cuando el Osservatorio Nazionale del MIUR habla de "laboratorios de idiomas permanentes", no da ninguna especificación. Luego,

\footnotetext{
${ }^{52}$ Todos los nombres son ficticios para garantizar el respeto a la privacidad de las personas entrevistadas.
} 
según las indicaciones ministeriales, podemos utilizar a los profesores de la plantilla, pero más bien a menudo, ellos no tienen las competencias lingüísticas necesarias.

Luisa, directora de un centro situado en una de las áreas de Palermo con mayor población inmigrante, nos describe una de las posibles soluciones para la enseñanza del Italiano L2, también adoptada por otras escuelas:

"El Italiano L2 no es una asignatura escolar! Entonces recurrimos a proyectos extracurriculares, pero también aquí... problemas... las financiaciones estatales no son suficientes... entonces los llevamos a cabo como una "misión" y con esfuerzo común con entes locales y del sector terciario, pero estas financiaciones tienen que ver con algunos meses o máximo un año... (continúa con tono enfadado). De todas las circulares, notas ministeriales y etcétera, no hemos tenido ninguna indicación para estructurar un horario didáctico que incluya el Italiano L2, tal como hacemos con las otras disciplinas: por ejemplo, sabemos que cada semana tenemos que programar un cierto número de horas de historia, geografía, etcétera, por cada clase y naturalmente los horarios están hechos a encaje de bolillos ¿Y cuándo podemos incluir el Italiano L2? ¿Boh?

La directora refiere, con un tono sarcástico, lo que señala el párrafo 1, apartado 7, letra r de la Ley 107/2015 y lo que ha afirmado la ministra Giannini en la presentación de la relación nacional de 2014/2015 del ISMU $^{53}$ refiriéndose a la educación intercultural y a la enseñanza de la lengua italiana como segunda lengua:

La escuela de la República es el lugar donde ningún estudiante está solo, dónde debe y puede sentirse como en su casa. [...] Con la "Buena Escuela" dirigimos nuestra atención a la necesidad de valorizar la educación intercultural y la enseñanza de la lengua italiana, como lengua segunda, en particular a los/las estudiantes

\footnotetext{
${ }^{53}$ ISMU (Iniciativas y Estudios sobre el Multietnicità) es una fundación, que tiene su sede en Milán, para producir y sustentar investigaciones e iniciativas sobre la sociedad multietnica y multicultural y sobre los fenómenos migratorios.
} 
de reciente inmigración. Por esta enseñanza nace la reciente y nueva clase de concurso A23, de la que forma parte el profesorado adecuadamente formado por la enseñanza de la lengua italiana en las escuelas secundarias de primero y segundo grado. (Giannini, 2016: 5).

Paola, otra directora escolar, evidencia las mismas dificultades que Daniele y Maria, señalando, además:

no sólo no tenemos la posibilidad de integrar las horas del currículo, porque la Ley no lo prevé, sino que organizamos todo gracias al voluntariado de los profesores. Es decir, hemos presentado un proyecto de Italiano L2 en horas extracurriculares porque el MIUR ha emitido decretos relativos a los criterios y parámetros de asignación de los recursos financieros destinados a estos proyectos... pues bien, nuestro proyecto ha sido aprobado y financiado... en teoría... pero, a día de hoy, estos recursos no han llegado... hemos contactado entes externos a la escuela... pero nada... el proyecto se ha realizado solamente gracias a la buena voluntad de los profesores y al voluntariado ofrecido por todo el personal de mi escuela, ¡voluntariado también económico!

Andrea, uno de los profesores de lengua italiana entrevistados ha explicado lo que algunos institutos están intentando, incluido el suyo, con modalidades diferentes, para facilitar el aprendizaje del Italiano L2 a los estudiantes extranjeros:

Actualmente hemos creado una solución transitoria: tenemos proyectos en curso, siempre extracurriculares, que agrupan alumnos con dificultades parecidas, teniendo sobre todo en consideración las franjas de nivel de conocimiento de la lengua italiana. Además, probamos estrategias didácticas con diferentes características en función de las necesidades del alumnado. Por ejemplo, si ellos usan y comprenden el italiano con un buen nivel, utilizamos medios audios-visuales, que compramos en todo caso de nuestro bolsillo... por ejemplo... vemos películas, o bien... escuchamos canciones y luego creamos un pequeño debate en lengua italiana partiendo de fragmentos de la película vista o de frases de canciones escuchadas 
Preguntamos a Luisa, profesora de Italiano L2 "¿qué tipo de proyecto está realizando?", a lo que nos contesta pensativa, titubeando al hablar del proyecto, desalentada:

No es fácil... necesitaríamos más proyectos, en más aulas, dividiendo a los chicos... por edad... por nivel de conocimiento de la lengua italiana... y por sus problemas de migración... es decir, deberíamos tener muchas horas a disposición, muchos profesores y sobre todo muchos materiales... pero no es siempre posible... iy, además tenemos nuestras clases curriculares...! Ahora tenemos en campo un proyecto de micro lengua, o sea, de la terminología específica de las asignaturas, ayudamos a los alumnos a hacer resúmenes de los libros de texto

Ángela, una profesora de otro instituto comenta, con relación a los proyectos que se desarrollan en su escuela:

"Es un experimento el nuestro! ¡Porque en todo caso nuestro objetivo es la integración de los alumnos extranjeros en el aula normalizada! En nuestro proyecto de aprendizaje del Italiano L2 creamos diálogos y jugamos con el italiano... pero sin indicaciones ministeriales es difícil... seleccionamos a los alumnos por niveles de conocimiento, tenemos necesidades de más profesores y si los dejamos en clase, no podemos desarrollar las lecciones cotidianas. En el proyecto tratamos varios niveles de italiano: por ejemplo, con un italiano excesivamente escolar aburrimos a los alumnos extranjeros que no tienen un dominio suficiente del italiano y con un italiano de conversación estamos lejanos del aprendizaje del Italiano de estudio. Y pensemos en algunos alumnos extranjeros que tienen otros problemas... es decir... cuando llegan aquí con situaciones trágicas... ¡Es una misión para nosotros profesores! 
Las palabras de Ángela y de Luisa nos recuerdan las afirmaciones de Graziella Favaro $^{54}$ :

los retratos de los niños y de los chicos que aprenden Italiano después de un camino de migración, nos remiten a historias personales, alfabetos y acentos, éxitos escolares, capacidad de movimiento con respecto el espacio lingǘstico del lugar de acogida. Y, por consiguiente, la gestión de esta importante variabilidad se convierte en tarea crucial y central por parte de los que enseñan. El docente de Italiano L2 y el docente de la clase multicultural y plurilingüe tienen que proceder cada vez más como equilibristas. Deben en efecto gestionar la heterogeneidad del grupo clase italófono y las variabilidades conexas a los diferentes caminos de los alumnos no italófonos"(Favaro, 2009: 288).

\section{Aprender el "Italiano L2" según la perspectiva de un grupo de estudiantes extranjeros}

Junto con el punto de vista de los profesionales de la escuela, conocimos el punto de vista de los estudiantes extranjeros que tienen que aprender la lengua del país de acogida.

La mayoría de los 29 estudiantes extranjeros entrevistados afirma que ninguna ley tiene en cuenta sus problemas relativos al aprendizaje de la lengua italiana, quejándose de la falta de una asignatura "Italiano L2". $\mathrm{Al}$ hilo de lo que se ha dicho, citamos algunas de las contestaciones a nuestra pregunta: "¿qué hace la escuela Italiana para ayudarte a aprender el Italiano L2?”

"Paolo, vive en Palermo desde hace 4 años y hablando un italiano todavía imperfecto, contestó:

ni mis compañeros ni yo aprendemos el italiano en la escuela[...] hablamos italiano porque estamos por la calle[...] hablamos italiano, pero mal con personas palermitanas que

\footnotetext{
${ }^{54}$ Graziella Favaro se ocupa, desde hace muchos años, de los temas relacionados con el aprendizaje/ enseñanza del Italiano como segunda lengua y de la integración escolar del alumnado inmigrante. Desde 1995 forma parte de la comisión nacional "Educación interculturale" del MIUR.
} 
están cerca de casa. Tú, profesora, que eres de la escuela ¿por qué no indicas que queremos hablar y entender italiano? [...] ¿puedes solicitar que venga un profesor para nosotros por la mañana para ayudarnos a entender y hablar bien?"

Mauro, 17 años, que vive en Palermo desde hace 3 años, hablando un italiano imperfecto, comentó:

¿qué es Italiano L2? no existe esta asignatura [...] jen la escuela hay el italiano y punto! Hablamos un poquito de italiano porque a veces tenemos lecciones verdaderas, pero por la tarde... ¡No entiendo a menudo a los profesores, cuando explican!... ¡Un ci capisciu niente! ${ }^{55}$

Luisa, vive en Palermo desde hace 5 años y asiste a cursos de Italiano L2 por la tarde en la escuela:

la escuela no hace mucho, no nos da clases por la mañana de italiano. Mi italiano no es igual al de los italianos, para nosotros es necesaria la clase de italiano porque me gustaría aprenderlo perfectamente. Las clases por la tarde crean problemas o no como y me quedo en la escuela o mi padre no va a trabajar para acompañarme.

Bernardo, en Palermo desde hace 6 años, expresa el deseo de aprender el italiano de estudio, el lenguaje específico de las diferentes asignaturas: hablo italiano, con mis compañeros y con los profesores, pero cuando tengo que estudiar o escuchar las explicaciones no entiendo nada, en la escuela no me enseñan el italiano de las asignaturas, de los libros, ¡no! No tenemos días establecidos como para las otras asignaturas. Hemos tenido lecciones de Italiano L2 algunas tardes, pero luego se terminaron. A mi madre le han dicho que no hay dinero para tener la escuela abierta por la tarde

\footnotetext{
${ }^{55}$ Mauro habla en dialecto siciliano: "Un ci capisciu niente" es decir "no entiendo nada".
} 
Marta, como los otros extranjeros, lamenta la falta de continuidad de aprendizaje de la lengua italiana y además añade:

en estos últimos dos años, cuando no podemos tener los cursos de Italiano L2, es la profesora de italiano que trata de ayudarnos a entender el italiano, ¡Todo el italiano! Lo hace porque nosotros no entendemos muchos términos de los libros de ciencias y luego de las otras asignaturas

\section{Conclusiones}

Todas estas entrevistas seguramente expresan las limitaciones de la Ley 107/2015 con respecto a la enseñanza y a el aprendizaje del Italiano L2 como asignatura escolar. Si comparamos los documentos legislativos escolares italianos y las entrevistas efectuadas, se puede observar que términos de la Ley como "interlingüismo", "Italiano L2", "integración lingüística" quedan, de momento, solo como bellas palabras.

En efecto, se destaca la petición inequívoca, del alumnado, del profesorado y de los/las directores/as de una verdadera asignatura con horarios bien definidos dentro de la programación didáctica, con profesionales especializados que puedan permitir un correcto aprendizaje del Italiano y sobre todo con continuidad didáctica, sine "indicaciones ministeriales" que delegan, una vez más, las escuelas a la organización didáctica cotidiana y a la resolución de los problemas y de todas las dificultades relacionadas al "Italiano L2".

A pesar de todas las innovaciones normativas teóricas de esta Ley, los centros educativos pueden modificar parcialmente su organización didáctica adecuándola a las exigencias, a las modalidades y a los tiempos de aprendizaje de los estudiantes extranjeros.

Sin tener normas bien definidas que determinen de modo estricto las intervenciones didácticas específicas, la solución que encuentran los profesionales educativos es adaptarse de modo flexible a las peticiones de los estudiantes extranjeros/ extranjeras: es decir, llevar a la práctica proyectos extracurriculares con o sin recursos financieros privados o públicos, intentar estrategias didácticas y actividades educativas más conformes a las necesidades lingüísticas de la pluralidad de alumnos extranjeros que cada centro escolar acoge con los medios y los 
materiales que cada centro tiene a su disposición, a menudo sólo por uno meses cada año escolar.

Todo esto plantea muchas amargas reflexiones y sobre todo deja una sensación de impotencia no estando en las condiciones de modificar una legislación escolar que lamentablemente en Italia no garantiza totalmente el derecho de enseñar y, por consiguiente, aprender la "lengua italiana L2".

Queremos subrayar lo que afirmaban, ya en 2005, docentes especializados en la enseñanza de las lenguas como Mónica Barni y Andrea Villarini:

la presencia de inmigrantes, en efecto, ha permitido en estos últimos años replantear cuestiones, intentar nuevas soluciones a problemas lingüísticos ya abiertos, hipnotizar nuevos escenarios con respecto a las políticas de difusión del italiano. He aquí entonces la cuestión de la lengua para los inmigrantes, lejos de ser una cuestión cerrada, es a todos los efectos una cuestión abierta (Barni e Villarini, 2005: 11)

A modo de conclusión, en la situación actual una buena teoría legislativa escolar no concuerda, en las escuelas, con la realidad organizativa/ didáctica del italiano como lengua del alumnado extranjero.

En Italia la cuestión del aprendizaje y del dominio de la "lengua del país de acogida", lejos de ser una cuestión cerrada, es a todos los efectos una cuestión abierta. Nos encontramos en un atolladero en el que todos los profesionales deben encarar un continuo reto pedagógico, educativo y organizativo para responder a la exigencia de aprendizaje lingüístico del alumnado extranjero, elemento esencial para la integración no solo escolar sino también a nivel social con vistas a obtener las mejoras oportunidades de empleo y la más activa participación en calidad de ciudadanos en la sociedad italiana.

\section{Bibliografía}

Anguera Argilaga, M. T., y Aguirre Baztán, A. (1995). La observación participante. Etnografía: Metodología Cualitativa En La Investigación Sociocultural, 73-84. 
Barni, M. e Villarini, A. (2005). La questione della lingua per gli immigrati stranieri. Insegnare, valutare e certificare l'Italiano L2. Milano: Franco Angeli.

Corbetta, P. (2016). Metodologia e tecniche della ricerca sociale. Bologna: Il Mulino.

Favaro, G. (2009). L'italiano L2: auto-apprendimento e narratività. Materiali multimediali di Italiano L2 per bambini e ragazzi. Italiano LinguaDue,1, 1. Recuperado del sitio web https://riviste.unimi.it/index.php/promoitals/article/view/445 $/ 633$

Gazzetta Ufficiale n.162. (2015). Legge 13 luglio 2015, n. 107. Riforma del sistema nazionale di istruzione e formazione e delega per il riordino delle disposizioni legislative vigenti. Recuperado del sitio web: http://www.gazzettaufficiale.it/atto/stampa/serie_generale/ori ginario

Gazzetta Ufficiale n.43. (2016). Supplemento ordinario n. 5/L alla Gazzetta Ufficiale Serie generale-n.43 Recuperado del sitio web: http:/ /www.istruzione.it/graduatoriedistituto/allegati/D.P.R.\% 2019_2016\%20Nuove\%20Classi\%20di\%20Concorso.pdf

Giannini, S. (2016). Alunni con cittadinanza non Italiana. La scuola multiculturale nei contesti locali. Rapporto nazionale A.S. 2014/2015. Quaderni Ismu 1/2016. Milano: Fondazione ISMU. Recuperado del sitio web:

http://www.istruzione.it/allegati/2016/Rapporto-Miur-Ismu2014_15.pdf

Macrì, F. (2018). Riflessioni - Alunni con cittadinanza non Italiana. 2016-2017. Recuperado del sitio web https:

// francescomacri.wordpress.com/2018/03/30/alunni-concittadinanza-non-Italiana-2016-2017-pubblicazione-reportMIUR/

Martín Rojo, L. (2003). Escuela y diversidad lingüística y cultural $¿$ Asimilar o integrar? Dilemas ante el multilingüismo en las aulas. Número 154. Colección: Investigación. Madrid. Solana e Hijos, A.G., S.A. 19-68.

MIUR - Ufficio Statistica e studi. (2018). Gli alunni con cittadinanza non Italiana A.S. 2016/2017. Recuperado del sitio web de: http://www.MIUR.gov.it/documents/20182/0/FOCUS+16- 
17_Studenti+non+Italiani/be4e2dc4-d81d-4621-9e5a848f1 f8609b3?version $=1.0$

Osservatorio Nazionale. (2015). Diversi da chi? Recuperado del sitio web de

http:/ / webcache.googleusercontent.com/search?q=cache:3Bb2 i0fAjnYJ:www.istruzione.it/allegati/2015/cs090915_all2.docx+ $\& \mathrm{~cd}=1 \& \mathrm{hl}=\mathrm{it \& ct}=\mathrm{clnk} \& \mathrm{gl}=\mathrm{it}$

USR-Sicilia. (2018). Dati delle scuole secondarie superiori - Sicilia. A.S. 2017

USR- Sicilia 2018. Recuperado del sitio web de: https://www.usr.sicilia.it/images/dati_delle_scuole/as_2017_1 8/OF_IIgrado_indirizzo_as2017_18.pdf 



\title{
Las lenguas de la comunicación de las trabajadoras domésticas filipinas de Mesina ${ }^{56}$
}

\author{
Maria Cama \\ Universidad de Granada, Instituto de Migraciones, España
}

\section{Resumen:}

$\mathrm{D}$ ESDE finales de los años setenta, el fenómeno migratorio en Italia tuvo como protagonistas a las mujeres. Actualmente, este carácter "femenino" de la inmigración persiste: más de la mitad de las personas inmigrantes extranjeras residentes hoy en día en este país son mujeres. Entre este colectivo se puede encontrar a un número considerable de mujeres procedentes de la República de Filipinas para la mayor parte de las cuales si la experiencia migratoria conlleva la mejora de sus condiciones económicas, al mismo tiempo supone la dificultad de mejorar su prestigio social. En este sentido juegan un papel importante tanto la lengua italiana como la lengua de origen, que lamentablemente no es ni reconocida ni debidamente valorada en la sociedad receptora.

\footnotetext{
${ }^{56}$ Este trabajo, una primera versión fue presentada en el IX Congreso Internacional Latina de Comunicación Social, La Laguna (Tenerife) en diciembre de 2017, pertenece a una investigación en fase de elaboración ligada a mi tesis doctoral sobre los usos lingüísticos de la comunidad inmigrante filipina de Mesina. Dicha tesis se está realizando en el Programa de Doctorado en Estudios Migratorios de la Universidad de Granada, bajo la dirección del Dr. F. Javier García Castaño, a quien quiero dar las gracias. También quiero agradecer al Ministerio de Educación italiano la licencia por estudios concedida para la elaboración de mi tesis doctoral.
} 
El texto pretende abordar la cuestión de las lenguas de las trabajadoras "extranjeras inmigrantes" a través de un estudio sobre las prácticas lingüísticas de un grupo de mujeres filipinas que viven en una ciudad de Sicilia: Mesina.

La atención a las explicaciones que las mismas protagonistas dan sobre las relaciones entre dominio de la lengua oficial, condiciones de vida y nivel de integración, permite no solo comprender sus dificultades sino también destacar cómo la naturaleza dinámica de la comunicación puede, a lo largo tiempo, producir cambios positivos en la vida de muchas de ellas.

Palabras clave: lenguas, filipinas, Italia, relaciones, trabajadoras domésticas

\section{Introducción}

Por la considerable presencia de mujeres inmigrantes en Italia, desde finales de los años setenta, principio de los ochenta, se ha llegado a hablar de "feminización" del fenómeno migratorio que, según muchos expertos, resulta significativa tanto en términos de cifras como por su carácter estructural. Según los datos de ISTAT (2017), en algunas comunidades, el colectivo femenino sobrepasa el setenta por ciento, como en el caso de la comunidad ucraniana local. Como distintos autores destacan (Bonora, 2011; Decimo, 2005; Muscarà, 2017; Solcia, 2011; Tognetti Bordogna, 2004), desde el comienzo de los años setenta hasta hoy, en la llegada a Italia de las mujeres se pueden distinguir tres fases que se diferencian no solo por procedencia sino también por tipo de proyecto migratorio.

La primera fase se caracteriza por la llegada de las precursoras, las llamadas "pioneras", obligadas a salir de su país principalmente por razones económicas y ayudadas por organizaciones católicas especializadas en el empleo de mujeres extranjeras en el ámbito de los servicios domésticos y de la asistencia a las personas. Se trata de mujeres caboverdianas, eritreas, latinoamericanas y, a finales de los setenta, filipinas que abren la cadena migratoria oriental. Estas mujeres, residiendo en las casas de sus empleadores, con escasas posibilidades 
de establecer relaciones con otras personas, son particularmente vulnerables ya que viven en un estado de segregación ocupacional, aislamiento e invisibilidad (Tognetti Bordogna, 2004).

En los años ochenta la "pioneras" construyen redes de apoyo para las recién llegadas, organizando su viaje, ofreciéndoles hospitalidad, ayudándolas a encontrar un trabajo y en algunos casos sufragando sus gastos de viaje (Tognetti Bordogna, 2004). Dichas mujeres preparan la acogida de amigas y conciudadanas que van a ocupar los lugares de trabajo que ellas dejan libres, según una sucesión que prevé el cambio de una situación laboral a tiempo total a otra como trabajadoras en régimen de contrato diario o por horas (Solcia, 2011). Durante esta década, muchas de ellas salen de la "segregación ocupacional" conectada con su papel de "criada de todo servicio" y comienzan a tener más tiempo libre, a ir de compras, a coger los medios públicos, a relacionarse con la gente autóctona. En estos años empiezan también a llegar aquellas mujeres que en su país de origen sufren situaciones de vulnerabilidad (viudas, divorciadas, repudiadas) impulsadas no solo por razones económicas sino también por la voluntad de escapar de situaciones de subyugación, violencia, pérdidas, separaciones o desempleo y por el deseo de reconstruir su vida (Decimo, 2005).

Los años noventa se caracterizan por un mayor equilibrio femeninomasculino desde el momento que empiezan a llegar maridos e hijos por razones de reunificación familiar. Este periodo ve una ulterior reducción de la "segregación ocupacional" del trabajo doméstico además del hecho de que algunas mujeres empiezan a trabajar también en otros sectores, aunque sea en casos excepcionales (ISFOL, 2009).

A diferencia de otros países donde la llegada de mujeres está vinculada a procesos de estabilización familiar (Decimo, 2005), en los flujos hacia Italia, ellas son las primeras en salir de su país de origen para trabajar aquí en el ámbito del hogar a cambio de remuneración. Y eso debido a una creciente demanda en el sector doméstico, relacionada con el envejecimiento de la población autóctona, con una más alta inserción de las mujeres italianas en el mundo laboral y con la falta de adecuados servicios públicos a las familias. Entre este colectivo podemos encontrar a numerosas mujeres procedentes de Filipinas, que pueden 
considerarse las protagonistas principales de aquella repartición de las actividades de reproducción social que ve a las mujeres occidentales delegar cada vez más el peso de los trabajos domésticos y la responsabilidad de la asistencia a los niños y a las personas mayores a las mujeres inmigrantes procedentes de los países del sur o del este del mundo (Banfi, 2008).

Para la mayor parte de ellas, la migración se caracteriza, sin duda, por una mejora de sus condiciones económicas pero también por la dificultad de adquirir prestigio social. Ninguna puede hacer un trabajo equivalente a su cualificación profesional o a sus títulos de estudio que en Italia no son reconocidos. La migración, por consiguiente, las lleva, como afirma Muscarà, "a la reescritura de su historia de vida y a una reelaboración de sus raíces culturales, a partir de un sí mismo proyectado hacia una nueva realidad" (Muscarà, 2017: 105) ${ }^{57}$. En el compromiso de "reescribir", a menudo arduamente, su propia historia, se inserta el esfuerzo del aprendizaje de la lengua del país de acogida y el parcial abandono de la lengua materna, considerada un verdadero obstáculo para la integración social. Las mismas personas inmigrantes perciben el hecho de dominar la lengua vehicular como un factor de integración, ya que viviendo y trabajando en contacto con la lengua del país de acogida, deben conocer usos y funciones diferentes para comprender y expresarse de forma coherente y no permanecer al margen del contexto comunicativo real (Sobrero y Miglietta, 2011).

La cuestión del aprendizaje de la lengua de acogida afecta tanto a las personas inmigrantes como a muchos países receptores (incluida Italia) que además de obligar a las personas que quieren establecerse y trabajar en ellos a demostrar sus competencias lingüísticas tampoco se preocupan de tener en cuenta sus lenguas de origen, subestiman el aspecto de la identificación y presionan para que, en lugar de compatibilizar los diferentes idiomas, abandonen una lengua en favor de otra (Cama, 2017).

Por esta razón hemos considerado importante abordar la cuestión de las lenguas de las mujeres "extranjeras inmigrantes", estudiando el

${ }^{57}$ La traducción es mía. 
conjunto de prácticas que un grupo de mujeres filipinas que viven en Mesina (Sicilia) desarrollan en la cotidianidad para comunicar, teniendo en cuenta que estas responden a necesidades distintas.

Si el objetivo general de nuestro trabajo de investigación consiste en analizar la comunicación en una comunidad que tiene una larga historia de migración, -la comunidad filipina de Mesina-, en este caso nos centramos en los hábitos lingüísticos de un conjunto de mujeres para comprender las dinámicas, los principios que los explican y sus consecuencias en la vida y en la organización cotidiana (Rojo y Mijares, 2007). El texto pretende comprender las relaciones entre sus prácticas lingüísticas cotidianas y su nivel de integración y registrar cómo las mismas protagonistas viven la pluralidad lingüística y cómo explican e interpretan lo que pasa en relación a las lenguas que hablan. Al final, lo que vamos a hacer es, a través de los individuos, "decir cosas sobre las situaciones", considerando que hablar de las situaciones es "hablar de las relaciones" que se generan y (re)producen en diferentes contextos" (García Castaño, Álvarez Veinguer y Rubio Gómez, 2011: 207).

\section{La inmigración filipina}

El Informe anual sobre la presencia de las personas inmigrantes del Ministerio del Trabajo y de las Políticas Sociales (2017) coloca la comunidad filipina en la quinta posición en la lista de los ciudadanos no comunitarios "regularmente" residentes y destaca en ella una "polarización de género". De hecho, la inmigración filipina se caracteriza por ser una inmigración prevalentemente femenina, como consecuencia de las necesidades de mano de obra en el sector de la asistencia doméstica, históricamente para ellas. Resulta que las mujeres son 93.094 sobre un total de 162.469 representando aproximadamente el 57,3\% (Ministero del Lavoro e delle Politiche Sociali, 2017) ${ }^{58}$.

\footnotetext{
${ }^{58}$ En el caso de la comunidad filipina, se constata una disminución de las presencias con respecto al año 2015, el descenso registrado es igual a más de cuatro mil presencias (-2,8\%), consistente en pasar de los 167.176 del 1 de enero de 2016, a los 162.469 del 1 de enero de 2017. Este dato es vinculado a dos fenómenos concomitantes: el descenso de las nuevas entradas y el considerable incremento de adquisiciones de las ciudadanías italianas.
} 
En este caso, más que en otros, el modelo migratorio ve como protagonistas a las mujeres, que desempeñan una función crucial con respecto a las rutas de emigración, a la decisión de salir de su país de origen y a las modalidades de inserción. Ellas son protagonistas activas en el mercado laboral y también en el proceso decisional, ya que casi siempre son titulares de un proyecto autónomo (aunque compartido con sus familiares), emprendido por la necesidad de mejorar las condiciones de vida propia y de su familia. Las primeras que emigran de Filipinas al final de los años setenta, comienzo de los años ochenta, están solas, son jóvenes y núbiles, casi siempre con un contrato laboral ya existente como trabajadoras de servicios domésticos obtenido gracias al apoyo de organizaciones católicas o de amigas (Dioli, 2009). Las que llegan en un segundo momento, siguiendo un patrón migratorio más peligroso, se encuentran en una posición jurídica de "irregularidad" (Malfone, 2006). A éstas últimas las apoya una extensa red femenina parental/amistosa, constituida por las más "expertas", que organizan la fase de la introducción de las recién llegadas (trabajo, alojamiento, documentación) y desarrollan papeles de guía y tutela (Banfi, 2008; Malfone, 2006; Favaro y Tognetti Bordogna, 1991). Los hombres (hermanos, maridos e hijos) llegan posteriormente, cuando las condiciones laborales y la disponibilidad de alojamiento lo permiten (en 1996 el porcentaje de mujeres en la comunidad filipina era en torno al $70 \%)$.

Un análisis sobre el mundo del trabajo (Ministero del Lavoro e delle Politiche Sociali, 2017) destaca que aún hoy la canalización de esta comunidad hacia este ámbito laboral se mantiene fuerte (el 70\% de los/as trabajadores/as filipinos/as se concentra en este sector). La especialización profesional ha protegido a la comunidad filipina de las graves repercusiones de la crisis económica a la que se enfrenta el país, siendo el sector de los servicios domésticos el menos afectado: la tasa de empleo, que es igual al 81,3\%, representa el porcentaje más alto entre las principales comunidades no europeas.

Sin embargo, su concentración en el sector doméstico tiene aspectos negativos: las personas italianas con las que entran en contacto son casi exclusivamente sus empleadores, por lo que están potencialmente expuestas a relaciones instrumentales y asimétricas. 
Por otra parte, si el pasar de una ocupación a tiempo completo en casa de una sola familia al trabajo doméstico por horas representa por un lado una conquista para estas mujeres, abriendo espacios de autonomía y posibilidad de ganar más, por otro implica una sobrecarga de trabajo, debida también al hecho de tener una casa propia, marido e hijos, con todos los problemas asociados (Solcia, 2011).

Se debe añadir otro elemento relevante: un cierto nivel de formación conseguido por las mujeres filipinas en el país de origen. En comparación con otras comunidades con prevalencia femenina, son mujeres con niveles de instrucción elevados, no obstante, la única movilidad social significativa posible para ellas en Italia sea la transición de una situación de trabajo doméstico con dedicación exclusiva al trabajo doméstico por horas.

\section{Las mujeres filipinas y las lenguas}

La mujer filipina continúa hoy en día representando en el imaginario colectivo el estereotipo de la "perfecta criada", solo por el hecho de que las primeras mujeres que encontraron este tipo de ocupación llegaron de Filipinas. Su inserción laboral en otros sectores resulta difícil sobre todo por el escaso conocimiento de la lengua italiana cuyo aprendizaje es casi siempre espontáneo. El trabajo doméstico no les permite mejorar sus competencias lingǘsticas porque no tienen tiempo para asistir a cursos de lengua y tienen escasas ocasiones de comunicar en italiano ya que a menudo se encuentran trabajando solas. El dominio de una lengua se puede fortalecer solamente a través de las relaciones interpersonales, dentro las cuales el intercambio comunicativo depende del saber dominar también la entonación y el lenguaje corporal. Al mismo tiempo "hacer suyo otro idioma facilita la construcción de las relaciones sociales y satisface las necesidades de aceptación y reconocimiento como persona en un nuevo contexto" (Muscarà, 2017:105). ${ }^{59}$

59 Traducción libre. 
De los datos emergidos por un estudio llevado a cabo en Italia con mujeres inmigrantes (Pozzi, 2014), resulta que las mismas reconocen sus escasas competencias en la lengua italiana y tienen conciencia de que no saber hablarla es un gran obstáculo sobre todo en las relaciones con las instituciones. A la vez muestran orgullo por la "lengua propia" y se declaran a favor de trasmitirla dado que poder hablar su lengua de origen y enseñarla a sus hijos significa darles la posibilidad de mantener sus raíces, el vínculo con su origen.

Su necesidad de aprender la lengua italiana está también ligada, en presencia de hijos, a la voluntad de desempeñar su papel de madres y a la exigencia de educarlos y seguirlos durante la trayectoria escolar, de supervisar su educación, de comunicar con los profesores y con las instituciones e incluso de mejorar la comunicación y la compresión entre las generaciones en el seno de la misma familia. Ellas no necesitan solamente aprender una lengua "instrumental" que pueden utilizar en los espacios públicos, fuera de su casa, sino una lengua a través de la que expresar sentimientos y emociones, que les permita comunicar con sus hijos (Solcia, 2011).

\section{Aspectos metodológicos}

Nuestro trabajo de campo ha tenido como objetivo interactuar con un conjunto de mujeres pertenecientes a la comunidad filipina de Mesina para comprender, a través de las explicaciones que ellas mismas dan de sus prácticas lingüísticas cotidianas, si y cómo el dominio y el uso de las mismas influyen en sus procesos de integración. Con este fin, elegimos una metodología de carácter cualitativo en una perspectiva microsocial. Si bien nuestro objeto de estudio (la gestión de las lenguas en contextos migratorios) se puede considerar un fenómeno de tipo "macro", porque tiene que ver con tendencias generales de la sociedad, al centrarnos en un pequeño grupo con historia de inmigración, nuestra perspectiva analítica será de tipo "micro", ya que nos permite analizar las interacciones, las interpretaciones y las experiencias subjetivas de los “actores" (Sautu y otros, 2005: 140). 


\section{Contexto}

La presencia de mujeres originarias de Filipinas en Sicilia empieza a registrarse a finales de los años setenta. Precisamente en 1979 es cuando llegan las primeras mujeres destinadas a ser empleadas como trabajadoras domésticas. La demanda creciente en el campo del trabajo doméstico y de asistencia a las personas con necesidades específicas hizo que la región se volviera atractiva para ellas. Hoy en día, la comunidad filipina, que ha sido una de las primeras en instalarse en Mesina (donde resultan 1.156 hombres y 1.257 mujeres), solo está por detrás de la comunidad cingalesa (3.996 personas) (Servizio Statistica Dipartimento Servizi al Cittadino Comune di Messina, 2016). Lo que llama la atención es que el $50 \%$ de las personas filipinas que resultan actualmente residentes en Sicilia se concentra en Mesina donde existe una prevalencia de mujeres y eso como consecuencia de la historia migratoria de una comunidad, empleada sobre todo en un sector de trabajo históricamente feminizado. Los datos disponibles nos muestran que hasta finales de 1980 la inmigración filipina es bastante circunscrita: se encuentran pequeños grupos, instalados sobre todo en las áreas urbanas, donde hay una demanda mayor de trabajo especialmente en el sector doméstico. Es en los primeros años noventa cuando el fenómeno se convierte en algo más consistente, por la presencia de grupos organizados, capaces de guiar los flujos de sus conciudadanos. El arraigo de esta comunidad está confirmado por las reunificaciones familiares que, a partir de 2010, se han convertido en las principales razones de ingreso. En este momento se registra una cierta estabilización, comprobada por la presencia de descendientes nacidos en Mesina. El crecimiento de los hijos ha implicado unas modificaciones en las relaciones en el seno de las familias, en el sentido de que estos últimos se convierten en verdaderos puntos de referencia en lo que respecta a la lengua italiana y proporcionan un fuerte apoyo en lo relativo a las relaciones con las instituciones (Cardullo, 2010), además de representar un poderoso estímulo al aprendizaje lingüístico.

\section{Las entrevistas}

Para la producción de datos útiles para nuestra investigación empleamos la técnica de la entrevista etnográfica guiada por un breve 
listado de preguntas abiertas, a las que las mujeres involucradas pudieron responder en total libertad, sin límites de tiempo ni opciones de respuesta establecidas. Como la entrevista es una técnica comunicativa que reduce la distancia entre el entrevistador y el sujeto entrevistado, nos dio la posibilidad de entablar una relación directa y personal. Las participantes son cinco mujeres elegidas a través del sondeo tipo "bola de nieve" que consiste en identificar a los sujetos a partir de los propios entrevistados (Corbetta, 2007), teniendo en cuenta en general las siguientes características: - años de permanencia en Mesina; - trabajo con contrato regular como trabajadoras de servicios domésticos; - familiares que viven aquí.

Las entrevistas se desarrollaron de forma individual y se transcribieron en un diario de campo siguiendo un mismo protocolo enfocado en:

a. Lenguas habladas;

b. Conocimiento previo de la lengua italiana, preocupaciones o dificultades iniciales y no solo;

c. Lugares de uso de la lengua italiana (cuándo, dónde, cómo, con quién);

d. Grado de satisfacción personal sobre de su nivel de comprensión y producción;

e. Lugares de uso de la lengua filipina (cuándo, dónde, cómo, con quién);

f. Las lenguas y los hijos (qué lenguas hablan con sus hijos y qué lenguas hablan sus hijos con ellas);

g. Importancia para ellas de que los hijos aprendan su lengua de origen.

En todos los casos obtuvimos el consenso para grabar, con la importante ventaja de poder transcribir fielmente las conversaciones, pero también con el inconveniente de la posible falta de espontaneidad al saber que se les estaba grabando (Silva-Corvalán, 2001). Los nombres de las participantes son ficticios, respetando la privacidad individual. 


\section{Las experiencias lingüísticas de las mujeres filipinas que viven en Mesina}

Las mujeres entrevistadas tienen necesidades lingüísticas específicas relacionadas con el tipo de proyecto migratorio, la experiencia previa, la tasa de alfabetización en la lengua materna, el deseo de integración y el tipo de vida que llevan en la nueva sociedad (Solcia, 2011). Además, como se puede desprender de sus discursos, las situaciones en que usan las lenguas y las formas de interacción que viven inciden en las relaciones que establecen entre las lenguas que hablan (Minuz, 2014).

Linda es una mujer de 56 años que cuando llegó a Italia, en 1990, estaba pensando en quedarse no más de cinco años, y en cambio ha pasado ya aquí la mitad de su vida. Está soltera y vive en casa con su hermano y su cuñada. Intentó llegar a Italia dos veces: una primera vez en avión, pasando por Hong Kong hasta Budapest, de donde, tras haberla encarcelado, la devolvieron a su país; y la segunda vez en un barco, desde Rumania hasta Mestre (Venecia) y de allí en tren hacia Roma, donde vivía uno de sus hermanos que la ayudó a buscar un trabajo. Al comienzo la preocupación más grande era no conocer la lengua ya que "antes de salir sabía que venía a hacer de criada, estaba mentalmente preparada al cambio, de un tipo de trabajo intelectual a uno que requiere mucha energía física". Cuando tenía que salir de compras por cuenta de sus empleadores para ella era un problema: "Tenía una gran confusión en la cabeza y siempre les pedía el favor que me escribieran una lista de lo que necesitaban". Por esto, A pesar de que el trabajo en casa no requiere una alta competencia lingüística, decidió hacer lo posible para aprender, leyendo artículos de prensa y estudiando durante todo su poco tiempo libre un libro de gramática en italiano y en inglés que alguien había tirado a la basura. Ahora está bastante satisfecha, aunque quiere seguir mejorando, a pesar de que para la vida que hace considera su nivel adecuado. Trabaja por la mañana y por la tarde en casa de una mujer con la que se encuentra justo el tiempo suficiente para despedirse, dado que al comienzo de su jornada laboral la señora sale de prisa para ir a trabajar. Lo bueno es que en la casa viven niños. Cuando los niños están en el colegio, ella solo puede interactuar con los "productos de limpieza" pero por la tarde, cuando regresan a casa de la escuela, la involucran en sus conversaciones y en sus actividades 
(juegos, películas en la tele), le enseñan un montón de palabras y la corrigen ("Linda, pero qué dices, no se dice así..."), ayudándola a mejorar su italiano. A ella le gusta mucho eso: los niños pueden ser maravillosos profesores, así que, a pesar de no tener hijos propios, los hijos de su empleadora le ofrecen una importante oportunidad. Por supuesto, la lengua que habla mejor es el tagalo, pero habla también inglés y algo de español. Aunque con sus conciudadanos habla más tagalo, -sobre todo con los recién llegados-, y a veces mezcla, porque "así nosotros nos entendemos mejor" dice, a menudo alterna las distintas lenguas que conoce, dependiendo de las circunstancias y de las lenguas que hablan sus interlocutores. Aunque el italiano sea la lengua que esta mujer habla más durante el día por razones de trabajo y sea también la lengua de los jóvenes hijos de personas filipinas que nacieron en Italia, ella piensa que es muy importante trasmitir la lengua de origen a las nuevas generaciones "porque siguen siendo filipinos/as y no deben renunciar al vínculo con su origen”. Además, le gustaría que otras personas que no sean de origen filipino aprendieran el tagalo porque "es realmente un idioma precioso" y puede ser útil a muchos.

Tessie es una mujer de 50 años y trabaja como cuidadora doméstica en mi casa. Tiene marido y tres hijos nacidos en Mesina que asisten a la escuela y van a la universidad y vive aquí desde 1993. Obtuvo el permiso de residencia de larga duración en 2011, seis meses después de haber finalizado las pruebas obligatorias de lengua prevista por la ley italiana (Cama, 2017). El título de estudio de Educación Superior obtenido en Filipinas nunca lo pudo disfrutar, ni en Italia ni tampoco en su país de origen. Su opinión sobre el trabajo que hace en casa no es aparentemente ni buena ni mala: lo concibe como un medio para hacer una vida digna con su familia en Italia donde sus hijos estudian, pero representa también la posibilidad para ahorrar y construir una casa grande y bonita en su país, donde disfrutar de vacaciones y vivir después de jubilarse. "Es mi trabajo", dice con aceptación, pero también con gratitud, "Cierto es que estoy harta de todo eso. Me gustaría hacer algo diferente, pero ¿cómo puedo?, es difícil...no soy joven y no hablo bien" ${ }^{60}$. Nos cuenta que la falta de conocimiento previo de la lengua italiana era fuente de preocupación antes de salir y

${ }^{60}$ La traducción es mía 
que su preocupación inicial se reveló como tal ya que sus dificultades lingüísticas le crearon problemas en el lugar de trabajo (sus primeros empleadores la despidieron por esa razón). Ahora dice que no tiene problemas, pero su nivel de competencia lingüística la satisface solo en parte y le cuesta entender todo, por eso habla poco con las personas que hablan italiano. A pesar de eso, no hace nada para mejorar: ni lee, ni estudia, ni va a cursos, solo intenta aprender a través de los programas televisivos. Le gustaría mejorar, pero dice que no tiene tiempo y además que tiene "una edad". El italiano se limita al lugar de trabajo, al mundo de la escuela de los hijos (profesores y padres de los compañeros de sus hijos), a las tiendas y las oficinas: lo habla por razones prácticas y porque es la lengua de sus hijos. Cuando viaja habla inglés en el exterior, pero también en Italia (en los aeropuertos por ejemplo). En italiano habla muy poco por no tener pleno dominio de la lengua, aunque añade que es también por su carácter reservado. Habla casi siempre tagalo: con sus amigas, con su marido y muchas veces con sus hijos a pesar de que esos últimos contestan en italiano. Habla también inglés, sobre todo en la iglesia, donde hace un uso alternado de inglés y tagalo. Cuando se refiere a su lengua de origen usa el verbo gustar: "Me gusta hablar filipino con mis amigos y familiares".

En el periodo escolar tuvo clases de español que ahora entiende, pero no sabe hablar. Sus hijos no hablan tagalo no obstante ella les hable en esta lengua para que no la olviden; los tres entienden bien pero casi nunca hablan y en las raras ocasiones en que dicen algo en tagalo tienen un acento "extraño". Para ella es muy importante que sus hijos aprendan la lengua de origen para poder comunicar con sus familiares que se han quedado en Filipinas (razones afectivas) y también quizás un día quieran volver allí para vivir. Le gustaría que ellos pudieran asistir a clases de tagalo que desafortunadamente no hay en ningún sitio en Mesina.

Rosemary, que tiene 43 años, llegó a Italia en 1993, cuando tenía 19. Estaba estudiando en el colegio y no había terminado su formación cuando maduró la idea de salir de su país en busca de trabajo. Trabajó durante unos años en Pisa como trabajadora doméstica a tiempo completo en la casa de una persona mayor antes de trasladarse a Mesina donde ahora vive con su marido y sus tres hijos. La lengua fue fuente 
de gran preocupación al momento de salir por el hecho de no poder entender a la gente y hacerse comprender. Tuvo que aprender todo, no solo cómo comunicar sino también cómo trabajar y lo consiguió con el apoyo de una red de familiares y amigas que la precedieron. Cierto es que por lo que concierne a la lengua italiana aprendió lo básico ya que tiene muchos problemas para expresarse de manera clara a pesar de que vive aquí desde hace muchos años: "más de la mitad de su vida" como ella misma afirma. Ella reconoce sus dificultades lingüísticas, nos cuenta su preocupación por ser rechazada cuando tuvo que hacer el examen obligatorio de lengua para obtener el permiso de residencia y nos dice que le gustaría mejorar su italiano pero que, considerada su edad, su nivel puede ser suficiente para seguir viviendo y trabajando aquí. Sus tres hijos, nacidos aquí, hablan italiano perfectamente y ella se esfuerza en hablar italiano con ellos. Lo mismo pasa en el lugar de trabajo, en el mundo de la escuela de los hijos y en todo lo relacionado con los trámites administrativos, solicitudes o demanda de asistencia médica. En general habla más tagalo, siempre que puede, porque "es más rápido". El tagalo es su lengua, la lengua que le gusta hablar, en la que comunica con su marido, amigos filipinos y familiares, la que le permite expresarse fluida y fácilmente (además del inglés que sabe hablar bastante bien), la lengua de su tierra, Filipinas, donde todas las veces en que ella vuelve se siente incómoda, "doblemente extranjera".

Ludy es una mujer de 54 años y trabaja aquí como asistente doméstica en varios hogares. Su marido y sus dos hijos viven y trabajan aquí y tiene también un nieto de tres años nacido en Mesina. Llegó a Milán en 1996 sin documentación, a través de un camino largo y peligroso que pasaba por Budapest y las montañas y se trasladó pronto a Mesina donde gracias a una red de conocidos encontró trabajo en una casa donde se hablaba inglés. No conocía ni una palabra de italiano y esto era motivo de inquietud y de malentendidos. Ahora habla bien tres lenguas (italiano, tagalo e inglés), que usa alternativamente en función de sus necesidades. Dice que ahora habla más en italiano. A pesar de afirmar que no comprende bien todo lo que la gente dice, habla con fluidez y contesta a todas las preguntas sin problema. Habla tagalo con sus familiares, sus amigos y sus hijos que nacieron en Filipinas y viven aquí, pero sobre todo tiene la costumbre de mezclar las lenguas y a veces tiene dificultad en recordar expresiones o palabras en su lengua 
de origen. Ella hablaba perfectamente inglés antes de llegar a Italia, cuando trabajaba en Kuwait (antes en casa y después en un hotel) mientras hoy solo lo habla durante las conversaciones telefónicas con su hermana que vive en Inglaterra y con su cuñado que es británico y además intenta enseñárselo a su nieto porque quiere que el niño lo aprenda. Aunque reconoce que es todo lo que ofrece el mercado, su grado de satisfacción frente al trabajo es bueno, así como bastante bueno su nivel de italiano: actualmente tiene un buen dominio del idioma, gracias a unos niños que cuidaba años atrás y puede mantener una conversación en italiano sobre diversos temas. Su vida social y afectiva está marcada por un uso alterno de las lenguas, pero la lengua italiana está plenamente integrada en su repertorio lingǘstico ocupando una parte predominante de sus intercambios comunicativos, no solo con los autóctonos sino también con las personas de su mismo origen: le sirve para hablar con sus empleadores, para hacer las compras, pedir y dar información pero también para comunicar con sus familiares y amigos y busca mejorar competencia y exactitud formal. Habla tagalo en los lugares públicos "por privacidad", cuando no quiere que la gente entienda sus discursos.

Nora, que tiene 51 años, vive en Mesina desde 1993 cuando salió de su ciudad, Luzón, para buscar trabajo aquí en los servicios domésticos. Trabaja mucho y en el poco tiempo libre que tiene se reúne con otros filipinos con los que habla tagalo y un poco inglés. Cuando ella llegó conocía solo algunas palabras italianas, aprendidas a través de un diccionario comprado para aprender simples fórmulas para pedir informaciones, saludar, dar las gracias. A pesar de su buena voluntad tuvo que cambiar lugar de trabajo muchas veces porque no hablando italiano sus empleadores la despedían. Afortunadamente una mujer que hablaba inglés para la que empezó a trabajar le ayudó a aprender, hablando mucho con ella y dándole clase de italiano. Hoy en día está bastante satisfecha porque su nivel, aunque no sea muy bueno, le permite comunicarse bien. Se expresa en italiano de manera adecuada para poder comunicar con sus empleadores, con los profesores de sus hijos y las madres de los compañeros de sus hijos aunque dice que a veces necesita aclaraciones durante las comunicaciones escuela-familia. En todos los otros momentos de su día habla sobre todo tagalo, también en los lugares públicos, si se encuentra en compañía de otros 
filipinos. En casa alterna tagalo e italiano porque sus hijos no entienden bien su lengua de origen y también porque ella piensa que escuchándola pueden aprenderla para poder comunicar con sus familiares.

\section{Evidencias}

De las entrevistas se desprende que la lengua materna tiene un importante papel en la comunicación cotidiana de las mujeres pero, al mismo tiempo, que la lengua italiana entra cada vez más en sus espacios comunicativos fuera y dentro de sus mismos hogares. Comprender y hablar italiano es para ellas fundamental para sentirse parte del nuevo contexto de vida y para poder acceder a los servicios públicos y a las oportunidades ofrecidas por el país de acogida. La lengua italiana representa la posibilidad de orientarse en la sociedad, de conocer los servicios que ofrece, de tomar decisiones, de conocer sus derechos para poderlos reclamar, la posibilidad de comunicar en el lugar de trabajo y con los vecinos y también de expresar su mundo interior a sus hijos. El tagalo representa en cambio el lenguaje del corazón, de las raíces, de los recuerdos de infancia, de los vínculos con los familiares que se quedaron en el país de origen y de las relaciones con amigos y conciudadanos. Un importante espacio lo ocupa la lengua inglesa que, aprendida desde pequeñas en Filipinas y practicada durante todo el periodo previo a la inmigración, es la lengua que hablan cuando viajan y comunican con los familiares que viven en Inglaterra o en Estados Unidos, el idioma de Internet, de las redes sociales, de las lecturas en el tiempo libre, de las canciones y de las oraciones, así como la lengua que impregna de términos su intercambios en la lengua de origen.

Sin embargo, casi todas las entrevistadas reconocen que su dominio del italiano no es bueno y su capacidad de expresión limitada y que eso es un problema ya que, siendo el idioma una base fundamental para la comunicación, un mayor control de la lengua les daría la posibilidad de interactuar mejor con la gente que la habla, incluso sus hijos. Al mismo tiempo, no tienen la posibilidad de hacer mucho para mejorar porque el tipo de trabajo en las casas no facilita el intercambio con otras personas ni la posibilidad de estudiar por falta de tiempo. Asimismo, la costumbre de reunirse a menudo con sus conciudadanos limita las ocasiones de contacto con la gente autóctona procurando el 
mantenimiento de su lengua de origen en la comunicación intergrupal no solamente en ámbito familiar sino también en algunos ámbitos públicos. La presencia de hijos o nietos nacidos aquí modifica los hábitos lingüísticos porque hace que las mujeres empiecen a hablar con sus hijos sobre todo en italiano o en más lenguas y menos frecuentemente en la lengua de origen. En cualquier caso, las lenguas que constituyen su repertorio lingüístico, aunque con distintas funciones, entran todas en juego en la comunicación cotidiana y en el tiempo acaban por entrelazarse, superponerse, mezclarse y ocupar espacios nuevos en un proceso de reconfiguración que modifica los equilibrios y produce cambios inevitablemente ligados a su inclusión social.

\section{Conclusiones}

Considerando la notable presencia en Italia de mujeres extranjeras inmigrantes, después de ocuparnos brevemente de los flujos femeninos que han caracterizado las últimas décadas, intentamos comprender el papel de las lenguas habladas por un grupo de mujeres filipinas que viven y trabajan en Mesina desde hace muchos años, registrando sus valoraciones personales.

Las mujeres con las que hemos llevado a cabo la investigación hablan por lo menos tres lenguas: tagalo, italiano e inglés. Cada una tiene diferentes niveles de competencia en las distintas lenguas y también distintas habilidades (escuchar, hablar, leer y escribir) para una misma lengua. Las lenguas no solo conviven sino también interactúan constantemente, ya que las emplean alternativamente en su comunicación cotidiana, dependiendo de la situación, de los propósitos, de los interlocutores y del contenido de la comunicación. El italiano no es solo la lengua del trabajo, de las instituciones y de las relaciones con las personas autóctonas y el idioma que deben certificar si quieren obtener un permiso para residir regularmente en Italia (Cama, 2017), sino también de los afectos porque es la lengua de sus hijos nacidos aquí. El tagalo es el idioma de sus raíces, el código de la continuidad afectiva y de la pertenencia, a través del cual transmitir a los hijos tradiciones culturales y valores. El inglés es la segunda lengua 
oficial de su país de origen cuyos términos a menudo se incorporan con su lengua materna.

Ciertamente, como afirma Favaro (2015) cada lengua adquiere con el paso del tiempo un peso y una importancia diferentes para las jóvenes y las más ancianas, para las solteras y aquellas que tienen familia. No obstante, todas pasan de una primera fase denominada "integración pasiva", en la que sus competencias lingüísticas no son suficientes para expresarse eficazmente durante una conversación, a una segunda fase llamada "funcional" donde su nivel lingüístico, aunque con errores, tiene características de eficacia comunicativa tanto en situaciones de carácter personal como en contextos profesionales. Considerando su larga permanencia en Italia, muchas de estas mujeres consiguen alcanzar una "integración lingüística proactiva" (Beacco y otros, 2014) es decir, se comprometen a mejorar su dominio de la lengua tanto para una mayor integración como por razones personales. Algunas incluso llegan a hablar prevalentemente italiano también en la vida privada, "convirtiéndose así la lengua de acogida en lengua adoptiva "coidentitaria" (Beacco y otros, 2014).

De sus discursos resulta que las situaciones son diversas y que los aspectos individuales y las motivaciones personales influyen en sus prácticas lingüísticas. Las variables que intervienen son muchas: la edad, el tiempo de permanencia en Italia, el tipo de trabajo, la formación previa, la predisposición individual, la presencia de hijos, las actividades y las relaciones en el tiempo libre, son factores determinantes, considerando además que el aprendizaje de la lengua es para muchas de ellas espontáneo. Si bien las políticas públicas en Italia se están ocupando de esbozar planes de formación lingüística en el territorio y de difundir cursos públicos, -como aquellos llevados a cabo en los CPIA (Centros de educación para adultos)-, o a través de proyectos subvencionados por el FEI (Fondo Europeo para la Integración), o promovidos por organizaciones de voluntariado-, no se trata aún de un verdadero "sistema", accesible a todos/as, continuo en el tiempo, con objetivos y propósitos claros y definidos en cuanto a destinatarios, tiempos y modalidades. 
Sin embargo, como afirman las mismas mujeres, las dificultades lingüísticas no constituyen un verdadero impedimento para la actuación de su proyecto migratorio, si bien el escaso conocimiento o la total la falta de conocimiento de la lengua, provocando perjuicio y malentendidos, es un obstáculo sobre todo en la fase inicial. Al mismo tiempo sus experiencias personales demuestran que la comunicación es un proceso dinámico que evoluciona, produce cambios y puede dar resultados positivos a lo largo del tiempo.

\section{Bibliografía}

Beacco, J. C., Little, D. y Hedges, C. (2014). L’integrazione linguistica dei migranti adulti. Guida per l'elaborazione di strategie e la loro attuazione. Council of Europe. Italiano LinguaDue, 1.

Recuperado el 20 de junio de 2017 de http://riviste.unimi.it/index.php/promoitals/article/view/4244 $/ 4337$.

Bonora, N. (2011). Donne migranti, protagoniste attive nei processi di trasformazione. Ricerche di Pedagogia e Didattica, 6, 1 - Pedagogia di Genere, 1-13.

Banfi, L. (2008). Lavoro domestico, politiche migratorie e immigrazione filippina. Un

Confronto tra Canada e Italia. POLIS $\square \square$ ó $\square \square \square$, XXII, 1, 5-34.

Cama, M. (2017). El conocimiento del italiano: requisito para obtener el Permiso de Residencia de larga duración CE. El caso de la comunidad filipina de Mesina (Italia). Revista Internacional de Estudios Migratorios, 7(3), 303-327.

Cardullo, S. (2010). Le nuove generazioni di immigrati: i ragazzi filippini a Messina. Quaderni di Intercultura, n.17, 1-18.

Centro Studi e Ricerche IDOS (2016). Dossier Statistico Immigrazione 2016.

Corbetta, P. (1999). Metodologie e tecniche della ricerca sociale.Bologna: Il Mulino.

Decimo, F. (2005). Quando emigrano le donne. Bologna: Il Mulino.

Dioli, I. (2009). Donne in viaggio: migrazione al femminile come fattore di cambiamento sociale. Osservatorio provinciale delle Politiche Sociali, Il volto femminile dell'immigrazione. Un ponte fra due 
rive. Rapporto di ricerca - intervento nella provincia di Piacenza, 25-43.

Favaro, G. y Tognetti Bordogna, M. (1991). Donne dal mondo. Strategie migratorie al femminile. Milano: Guerini Associati.

Favaro, G. (2015). L'italiano è la libertà, l'italiano è una montagna.

Desideri, bisogni e rappresentazioni della nuova lingua nei corsi per le donne immigrate. Italiano LinguaDue, 1, 50-59.

García Castaño, F.J., Álvarez Veinguer, A. y Rubio Gómez, M. (2011). Prismas transescalares en el estudio de las migraciones. Revista de Antropología Social, 20, 203-228.

ISFOL (2009). Analisi degli interventi d'integrazione rivolti alle donne immigrate.

ISTAT (2017). Migrazioni internazionali e interne della popolazione residente - 2016. Recuperado el 10 de enero de 2018 de https://www.istat.it/it/files/2017/11/Report_Migrazioni_Ann o_2016.pdf

Malfone, C. (2006). Immigrazione al femminile. Modelli femminili, valori, identità. Pedagogia Interculturale, Sociale e della Cooperazione, 1, $1-22$.

Ministero del Lavoro e delle Politiche Sociali, Direzione Generale dell'Immigrazione e delle Politiche di Integrazione (2017). La Comunità Filippina in Italia. Rapporto annuale sulla presenza dei migranti. Recuperado el 08 de marzo de 2018 de: http:

//www.integrazionemigranti.gov.it/Areetematiche/PaesiComu nitariassociazioniMigranti/Documents/RAPPORTI_COMUNITA_ 2017/RC_FILIPPINE_DEF.pdf

Minuz, F. (2014). La didattica dell'italiano in contesti migratori. Gentes, 1 (1), 107-112.

Muscarà, M. (2017). Donne, linguaggio e relazionalità. Dimensione interculturale e plurilinguismo. Women, language and relationality. Intercultural dimension and plurilingualism. Pedagogia Oggi/Rivista SIPED, XV (1) 103-115.

Pozzi, S. (2014). Trasmissione delle lingue, integrazione e identità nelle famiglie immigrate. En M.V. Calvi, I. Bajini y M. Bonomi, Lingue migranti e nuovi paesaggi. Milano: Led edizioni, 37-50. 
Rojo, L.M. y Mijares, L. (2007). "Sólo en español": Una reflexión sobre la norma monolingüe y la realidad multilingüe en los centros escolares. Revista de Educación, 343, 93-112.

Sautu, R., Boniolo, P., Dalle, P., y Elbert, R. (2005). Manual de metodología. Construcción del marco teórico, formulación de los objetivos y elección de la metodología (p. 173). Buenos Aires, Argentina: CLACSO.

Servizio Statistica Dipartimento Servizi al Cittadino di Messina (2016). Recuperado el

07 de enero de 2018 de: http://www.comunemessina.gov.it/statistica/bilanciodemografico-comunale-anno-2016/

Silva-Corvalán, C. (2001). Sociolingüistica y pragmática del español, Washington D.C., Georgetown: University Press.

Sobrero, A. y Miglietta, A. (2011). Per un approccio varietistico all'insegnamento

dell' italiano a stranieri. Italiano LinguaDue, 3(1), 233.

Solcia, V. (2011). Non solo lingua. I corsi di italiano L2 per donne migranti tra bisogni linguistici e desiderio di integrazione. Italiano LinguaDue, 2, 129-200.

Tognetti Bordogna, M. (2004). Lavoro e immigrazione femminile in Italia: una realtà in mutamento. En M. Delle Donne y U. Melotti (eds.), Immigrazione in Europa. Strategie di inclusioneesclusione. Roma: Ediesse. 



\section{$\wedge$}

\section{Los autores}

José Manuel Maroto Blanco. Graduado en Historia y Máster en Cooperación al Desarrollo y Gestión de la ONGD y Profesorado en Educación Secundaria Obligatoria y Bachillerato por la Universidad de Granada (UGR). Doctorando del Programa de Estudios Migratorios de la UGR y contratado predoctoral FPU del Departamento de Historia Contemporánea de la UGR. Actualmente está realizando su tesis doctoral sobre la continuidad de las lógicas coloniales en España desde el Segundo Franquismo hasta la actualidad. Entre sus publicaciones podemos destacar: "Miedos y prejuicios de una nación. La negritud y la figura del negro en la Historia reciente de España a través del cine (1959-2002)" publicado en Historia Social, Cuarenta años de literatura sobre la experiencia africana en España: Identificación de una literatura producida desde la "herida colonial" en Tonos o "Prejuicios sobre África en los libros escolares de Educación Secundaria" en Historia Actual Online.

Rosalía López Fernández. Diplomada en Trabajo Social, Licenciada

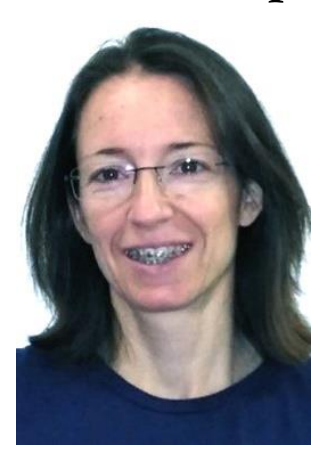
en Antropología Social, Máster en Cooperación al Desarrollo y Gestión de la ONGD y Profesorado en Educación Secundaria Obligatoria y Bachillerato por la Universidad de Granada (UGR). Ha sido contratada predoctoral en el programa de Formación de Profesorado Universitario en el Departamento de Antropología Social de la UGR. Sus líneas de investigación se centran en las representaciones sociales de pobreza desde una perspectiva interseccional. 


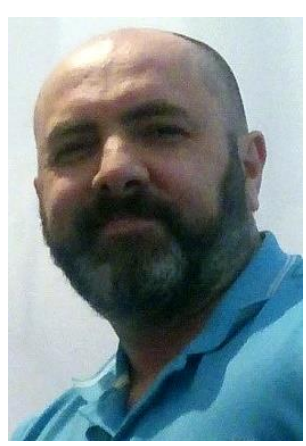

Alberto Capote. Doctor en Geografía Humana y actualmente profesor en el Departamento de Geografía Humana de la Universidad de Granada. Imparte docencia en los Grados de Antropología y Geografía y Gestión del territorio. Realizó su post doctorado en la Universidad de Casablanca Hassan II. Sus líneas de investigación van orientadas al estudio de las migraciones internacionales, la Geografía de la Población y Geografía Urbana.

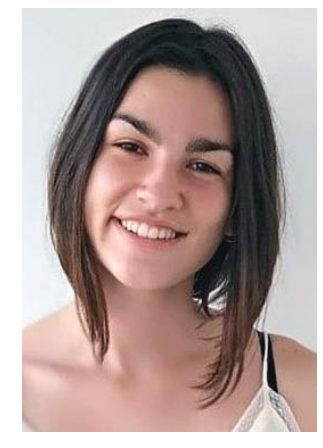

Marta Zornoza Madrid. Estudiante del Grado de Antropología Social y Cultural en la Universidad de Granada. Actualmente es cursante también de una beca de iniciación a la investigación en el Instituto de Migraciones de la misma universidad.

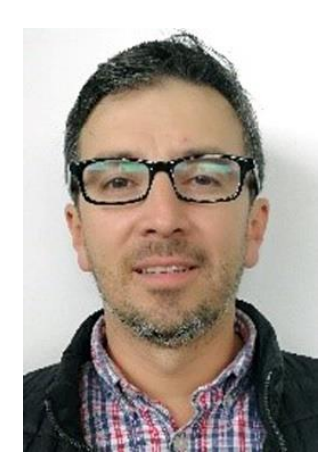

Leonardo Xavier Brito Alvarado. Licenciado en Comunicación Social por la Universidad Central del Ecuador. Máster en Comunicación por la Universidad Andina Simón Bolívar. Magíster en Antropología por la Facultad Latinoamericana de Ciencias Sociales FLACSO - Ecuador. Estudios doctorales en Comunicación por la Universidad Carlos Tercero de Madrid. Docente en la Universidad Técnica de Ambato

- Ecuador.

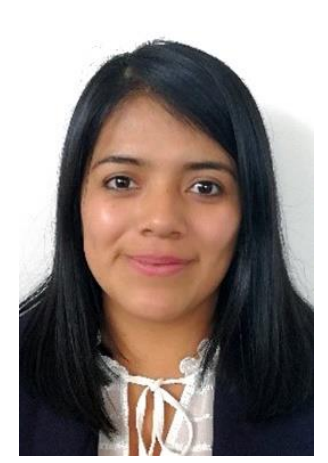

Nelly Gabriela Guamán Guadalima. Licenciada en Relaciones Públicas por la Universidad Técnica Particular de Loja Máster en Investigación en Comunicación y Periodismo por la Universidad Autónoma de Barcelona. Estudios doctorales en Comunicación y Periodismo por la Universidad Autónoma de Barcelona. Docente en la Universidad Técnica de Ambato - Ecuador. 


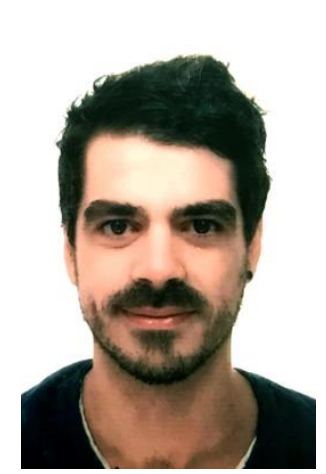

Gianluca Gaias. Doctorando en geografía en la Universidad de Cagliari, mi actividad académicocientífica se mueve alrededor de la pasión por la disciplina geográfica en sus diversas formas, concentrándome en su dimensión urbana y humana. Partiendo de temas como el territorio, el paisaje y las identidades territoriales y comunitarias, gradualmente me interesé en la sociedad como producto de interacciones continuas, movimientos y movilidad e interconexiones tanto a nivel local como sobre todo a nivel transnacional. Tuve la posibilidad de trabajar en diferentes contextos territoriales (Italia, Francia, España, Marruecos) sobre temas en torno a los cuales se articula mi producción académica: movilidad humana y migración transnacional, con atención a dinámicas y transformaciones de los espacios urbanos; religiones y comunidades de la diáspora, con especial interés en el tema espacial; dinámicas patrimoniales y turísticas; de manera más general, los temas que giran en torno al objeto de "ciudad" y los temas de la movilidad. La vocación interdisciplinar de la geografía aumenta la dimensión popular y la propensión de la investigación a volverse pública y compartida. Por eso, creo también que sean relevantes las formas de la "comunicación de la ciencia", a través del desarrollo y uso de canales de difusión paralelos y / o alternativos a la difusión de resultados "clásicos".

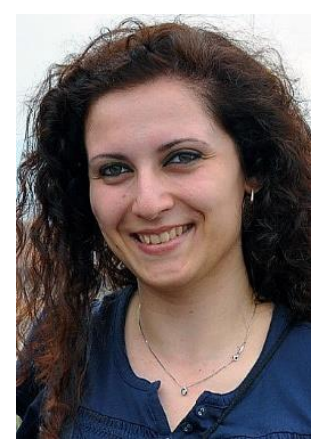

Rosella Bianco. Doctoranda del programa 'Estudios migratorios' del Instituto de Migraciones de la Universidad de Granada. Ha realizado sus estudios de grado en la Universidad de Salento (Italia) donde se ha formado a través de un master en lenguas modernas para la comunicación internacional y otro master en mediación lingüística intercultural en el campo de la inmigración y asilo. Cuenta con experiencia laboral en el ámbito de la enseñanza del italiano, concretamente en la enseñanza para estudiantes de italiano lengua extranjera, en la preparación al test de lengua italiana para inmigrantes, así como en cursos de lengua y alfabetización para refugiados. 


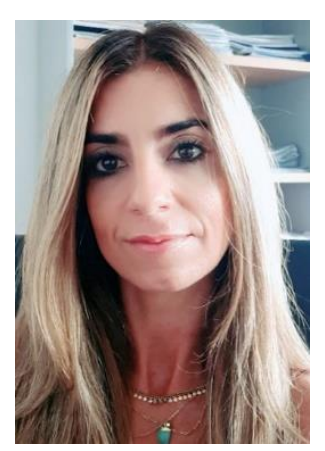

Mónica Ortiz Cobo. Doctora europea en Antropología Social y profesora del Departamento de Sociología de la Universidad de Granada. Miembro del grupo de investigación "Laboratorio de Estudios Interculturales" y del Instituto de Migraciones de la Universidad de Granada. Participa como docente en el programa de doctorado de "Estudios Migratorios" y en el master de "Mediación Social" de la UGR, así como en el master en "Estudios e Intervención Social en Inmigración, Desarrollo y Grupos Vulnerables" de la Universidad de Almería. Su línea de investigación se centra en el estudio de procesos culturales en contextos educativos diversos.

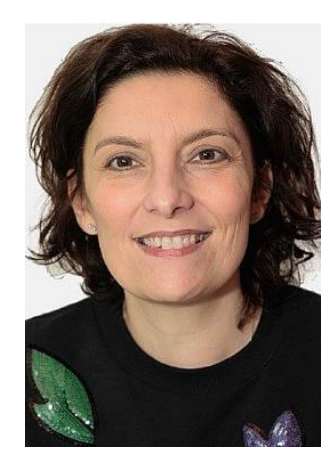

Alessandra Cama. Licenciada en "Lenguas y Literaturas Extranjeras Modernas" por la Universidad de Mesina (1995). Profesora de Español Lengua Extranjera en la Escuela Secundaria en Italia desde 2001 y doctoranda en el Programa de Estudios Migratorios de la Universidad de Granada. En la actualidad se encuentra en la fase final de redacción de su tesis doctoral. Su principal línea de investigación: análisis social, cultural y de género de las migraciones. Ha publicado en temas de migraciones y escuela, alumnado con necesidades educativas y sobrerrepresentación de escolares de nacionalidad extranjera.

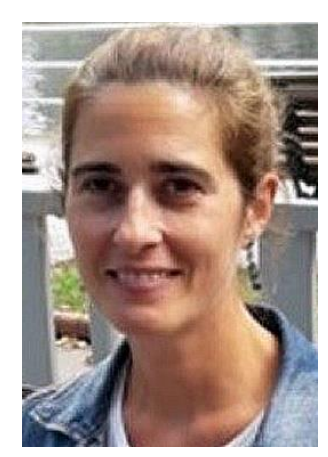

Amaia Garcia. Doctora por la Universidad del País Vasco, con mención Cum Laude, en Estudios sobre Desarrollo y ha sido profesora agregada en la Cámarabilbao University Business School, en el área de economía desde 2003 hasta septiembre de 2019, que pasa a formar parte del profesorado de la Universidad del País Vasco (UPV/EHU) en el Departamento de Economía Aplicada I. Su labor docente e investigadora cubre diversos ámbitos de la economía y la sociología, donde se superponen los conocimientos sobre mercado laboral, macro y microeconomía, con los flujos migratorios 
internacionales (especialidad del doctorado), manteniendo la perspectiva de la economía internacional y del desarrollo (especialidad de la licenciatura), añadiendo a todo ello el enfoque de género, y en ocasiones, la variable del papel que juegan los medios de comunicación. Asimismo, es máster en e-Business por la Universidad de Deusto y máster en Globalización y Desarrollo por la Universidad del País Vasco. Posee amplia experiencia en asesoramiento a directivos en temas de Comercio Exterior, Estrategias y Marketing, habiendo participado en varios proyectos de investigación en los últimos años.

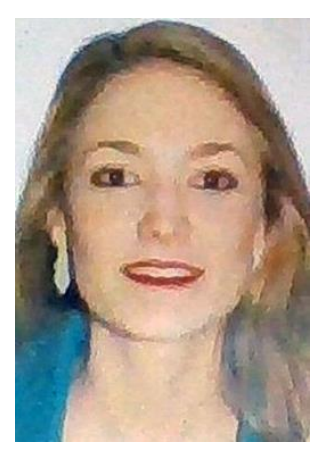

Ariet Castillo Fernández. Investigadora predoctoral del Instituto de Migraciones (UGR) con contrato FPU (17/05600) Profesora del Departamento de Antropología Social en la Facultad de Filosofía y Letras. Licenciada en Publicidad y Relaciones Públicas (UCM), Graduada en Antropología Social (UNED), Máster en Antropología y sus aplicaciones (UNED), a falta de Trabajo Fin de Máster. Investigación doctoral en curso en el Programa de Doctorado de Estudios Migratorios (UGR) sobre la representación mediática del fenómeno migratorio.

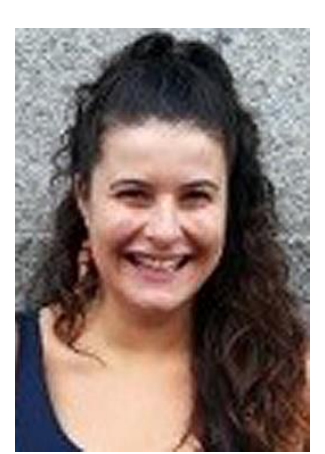

Rocío González Rey. Licenciada en Periodismo por la Universidad Complutense de Madrid y Máster en Cultura de Paz, Conflictos, Educación y Derechos Humanos por la Universidad de Granada. Ha colaborado con Melilla Acoge en el Centro de Estancia Temporal de Inmigrantes de la ciudad y en diferentes proyectos de Cooperación Internacional en Senegal. Ha participado en varios proyectos periodísticos $y$ actualmente colabora en radios comunitarias de Madrid, además de ser activista en SOS Racismo. 


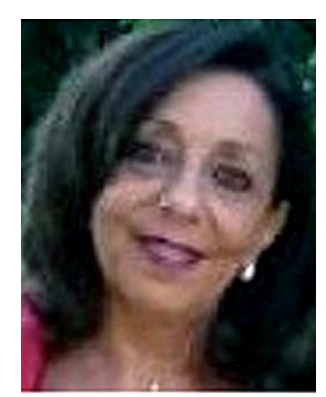

Vincenza Indelicato. Licenciada en "Lenguas y Literaturas Extranjeras" por la Universidad de Palermo (1993). Especializada en "didáctica y metodología de la lengua y la literatura francesa". En la actualidad es profesora en la escuela secundaria de segundo grado en Palermo con contrato permanente del MIUR (Ministerio de Educación, Universidades e Investigación italiano). Actualmente doctoranda en el Programa de Estudios Migratorios de la Universidad de Granada y se encuentra en fase final de redacción de su tesis doctoral centrada en el uso de la lengua italiana por parte de los/las estudiantes extranjeros/as que asisten a la escuela secundaria de segundo grado en Palermo. Ha participado en varios seminarios en Granada y en Palermo, en la "II Jornadas de Investigadores en Formación: fomentando la interdisciplinariedad" (Granada, 2017), en la IV edición del Congreso de AIBR (Granada, 2018) presentando informes dirigidos al aspecto lingüístico del alumnado extranjero.

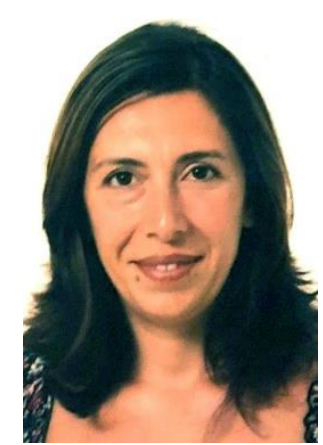

Maria Cama. Licenciada en "Lenguas y Literaturas Extranjeras Modernas" por la Universidad de Mesina (1993). Experta en didáctica y metodologías de enseñanza y aprendizaje de lenguas extranjeras en la escuela primaria. Docente con contrato permanente del Ministerio de Educación italiano desde 1996 y doctoranda en el Programa de Estudios Migratorios de la Universidad de Granada. En la actualidad se encuentra en la fase final de redacción de su tesis doctoral. Su principal línea de investigación abarca el área de las políticas lingüísticas y sociológicas vinculadas a las migraciones. Ha publicado en temas de lengua/as, integración y procesos de identificación en contextos migratorios. 